Portland State University

PDXScholar

7-13-2020

\title{
Evaluating R\&D Projects in Regulated Utilities: the Case of Power Transmission Utilities
}

\author{
Edwin Garces \\ Portland State University
}

Follow this and additional works at: https://pdxscholar.library.pdx.edu/open_access_etds

Part of the Power and Energy Commons

Let us know how access to this document benefits you.

\section{Recommended Citation}

Garces, Edwin, "Evaluating R\&D Projects in Regulated Utilities: the Case of Power Transmission Utilities" (2020). Dissertations and Theses. Paper 5513.

https://doi.org/10.15760/etd.7387

This Dissertation is brought to you for free and open access. It has been accepted for inclusion in Dissertations and Theses by an authorized administrator of PDXScholar. Please contact us if we can make this document more accessible: pdxscholar@pdx.edu. 
Evaluating R\&D Projects in Regulated Utilities: The Case of

Power Transmission Utilities

\begin{abstract}
by
Edwin Garces requirements for the degree of

\author{
Doctor of Philosophy \\ in
}

Technology Management
\end{abstract}

A dissertation submitted in partial fulfillment of the

Dissertation Committee:

Tugrul U. Daim, Chair

Marina Dabic

Judith Estep

Loren Lutzenhiser

Portland State University

2020 
(C) 2020 Edwin Garces 


\begin{abstract}
R\&D project selection is essential for many organizations; however, it is a complex decision since it is affected by many factors. These factors vary among organizations because of their different objectives and conditions. There are limited budgets for the investments, and the current $R \& D$ project selection methods are focused on financial analysis or complex mathematical probabilistic calculations. Therefore, the main motivation of this research is to create a method to help improve the ex-ante selection of $\mathrm{R} \& \mathrm{D}$ projects in regulated organizations. More importantly, the case application is the electric transmission utilities sector, which plays one of the most critical roles in the entire electric power system.
\end{abstract}

The main objective of this research is to develop a model to select $R \& D$ projects based on a holistic approach aligned to strategies, utility objectives, and market conditions in the electric transmission sector. At the same time, it identifies, categorizes, and quantifies the factors associated with $\mathrm{R} \& \mathrm{D}$ projects in the power sector. The analysis is framed into a multi-criteria model (Hierarchical Decision Model - HDM [1]), which considers all the aspects associated with $R \& D$ projects. The model and the application are potentially applicable to non-profit and regulated organizations around the world. Moreover, the flexibility of the model allows it to be adopted by electric transmission utilities with similar characteristics to utilities in the United States. This study provides an extensive literature review about regulated organizations, and more specifically about electric transmission utilities. Additionally, a complete analysis of criteria and sub-criteria 
has been done. There are gaps in the literature that have been identified and that support the idea of using a multi-criteria analysis to evaluate $R \& D$ projects. The methodology is described, and the application of the model is provided. 


\section{DEDICATION}

This dissertation is dedicated to the memory of my father Huberto and sister Roxana. I also dedicate it to my family for their unconditional support. 


\section{ACKNOWLEDGEMENTS}

To develop and complete this thesis would not be possible without the contribution and support of the people around me. I consider myself fortunate for having these wonderful people that always will own my eternal gratitude.

I wish to acknowledge the support and love of my family, my mother Irma, my sister Lizzia and my late sister Roxana who lives forever in my heart.

I would like to express my deepest gratitude to my advisor Dr. Tugrul Daim, who has supported me throughout my studies and this thesis research. I am grateful for his advice and how he shares his academic knowledge, his pragmatic advice, for teaching us and driving us to be part of the academic world. Thank you to Dr. Daim for his encouragement and advice in completing this thesis.

I would like to thank and recognize the invaluable assistance of my committee members, Dr. Judith Estep, Dr. Marina Dabic, and Dr. Loren Lutzenhiser. Thank you for providing guidance and feedback throughout this project, without their inputs, comments, and always willing to meet would do possible to complete my research objective.

I would like to express my deepest thank and sincere appreciation to all subject matter experts whose assistance was a milestone in the completion of this project. All the experts, who are very busy because they are recognized professionals; however, they gave me their time and opinions for building, formulating, and validate the model of the thesis. This thesis would not have been possible without their immense valuable input. 
I wish to thank all my friends, faculty and doctoral colleagues at my department, Engineering and Technology Management (ETM). All efforts I made were always with the support of them, sharing wonderful times, advice, and our pleasing chats about our research. I appreciate their encouragement to always go ahead and see forward to complete this research and objectives. 


\section{TABLE OF CONTENTS}

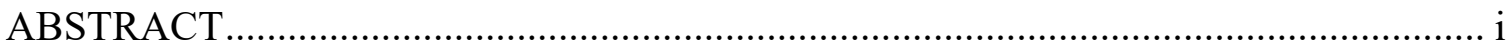

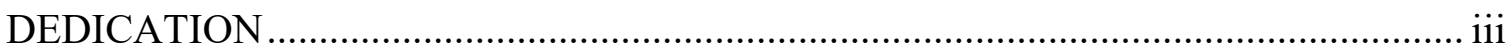

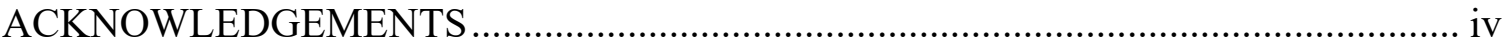

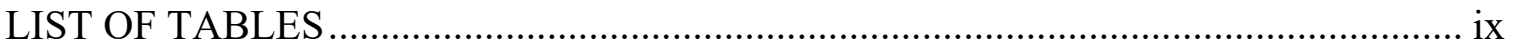

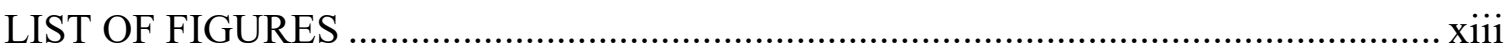

LIST OF ABBREVIATIONS ......................................................................... xvii

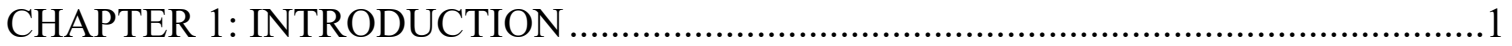

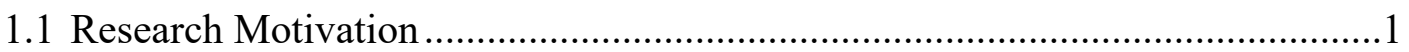

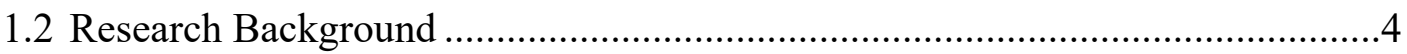

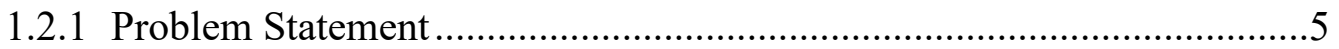

1.2.2 R\&D Levels of Investment in the Electrical Power Sector .....................12

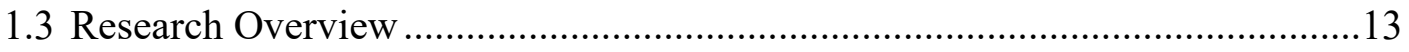

1.3.1 Research Objectives and Contributions ...................................................14

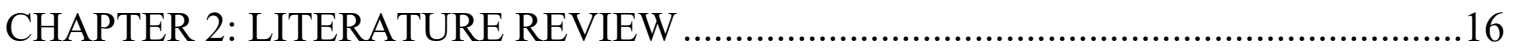

2.1 Market Structure of Power Systems …………………...............................17

2.1.1 Definition of Utility .............................................................................19

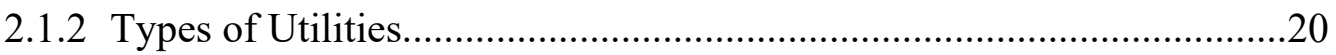

2.1.3 Characteristics of Public Utilities .........................................................21

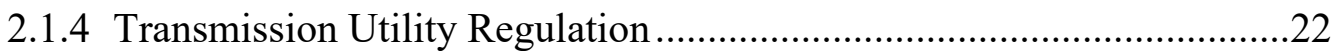

2.1.5 Governance/Regulation of Wholesale Power Market...............................23

2.2 Business Models - Structure Power Markets .....................................................24

2.2.1 Investor-Owned Utilities (for Profit Ownership).......................................

2.2.2 Non-profit Ownership Models.................................................................29

2.2.3 Electric Markets and Utilities' Ownership Structure................................31

2.3 R\&D investment by Electric Utility Model .......................................................35

2.4 Factors Influencing R\&D Project Selection .....................................................38

2.5 R\&D Project Selection Methods.....................................................................46

CHAPTER 3: RESEARCH GAPS and GOALS ......................................................... 


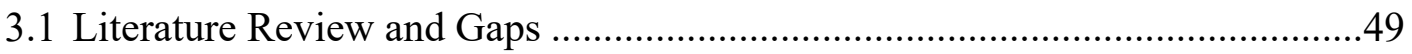

3.1.1 Gaps by Related by Topic ......................................................................53

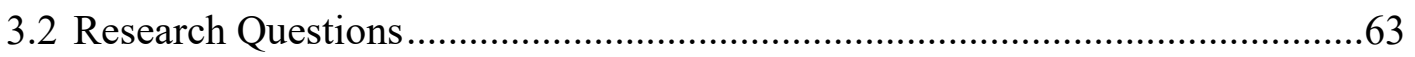

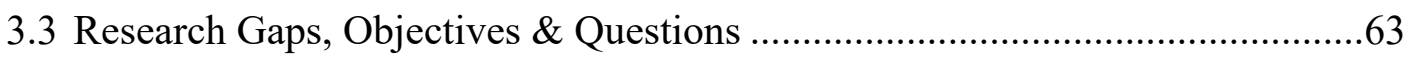

CHAPTER 4: RESEARCH APPROACH AND METHODOLOGY ...............................65

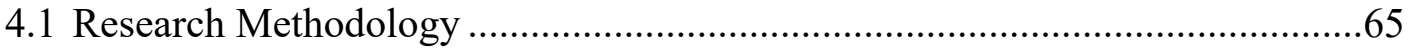

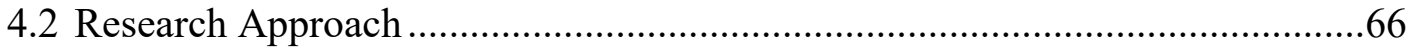

4.3 Justification of the Method .......................................................................68

4.3.1 Financial Analyses for Transmission Technology R\&D Project Decision Making in the Context of Transmission Utility .......................................70

4.4 Hierarchical Model Development....................................................................

4.5 Validation of the HDM Model.....................................................................

4.6 Judgment Quantification..............................................................................72

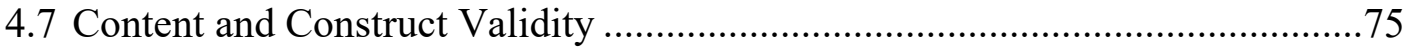

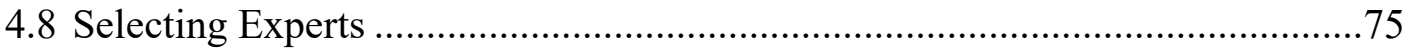

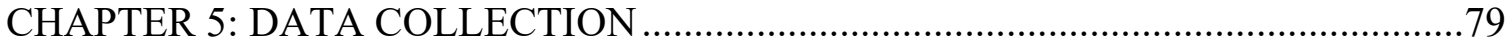

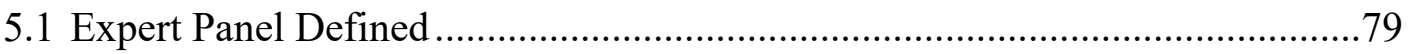

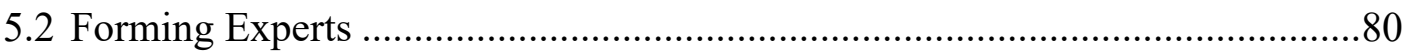

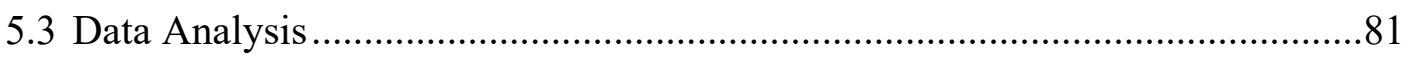

5.3.1 Inconsistency Analysis and Group Disagreements.................................81

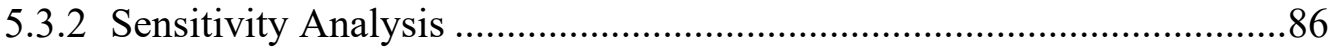

CHAPTER 6: DEVELOPMENT OF THE RESEARCH MODEL .....................................89

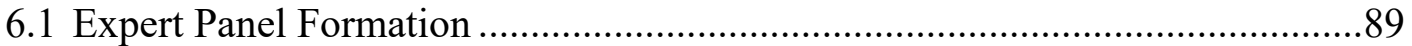

6.2 Results and Data Analysis - Research Application ..........................................92

6.3 Step 1: Hierarchical Model Development ……………...................................92

6.4 Step 2: Model Development Update based on Identification of Supporting

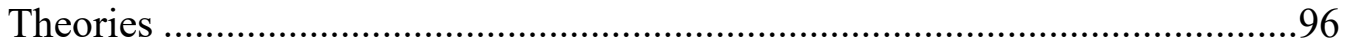

CHAPTER 7: RESULTS OF MODEL QUANTIFICATION...........................................103

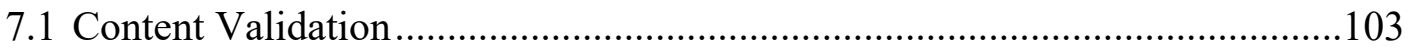

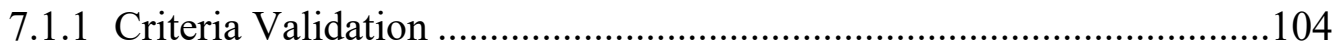

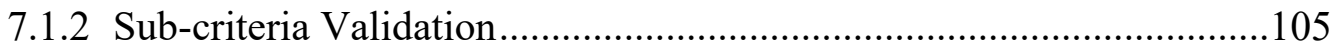

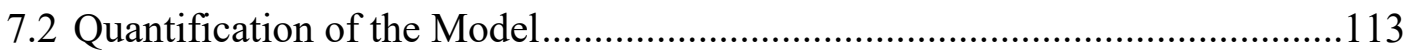


7.2.1 Criteria Quantification Results 114

7.2.2 Sub-criteria Quantification Results.....................................................115

7.2.3 Quantification: Analysis of the Differences Between Criteria .122

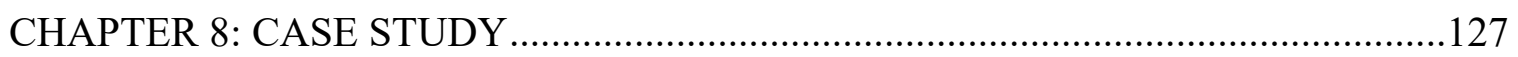

8.1 Overview of Case Application Organization....................................................127

8.1.1 Power Marketing Agencies (PMAs) ..................................................130

8.1.2 Regional Transmission Organizations and Independent System Operators .131

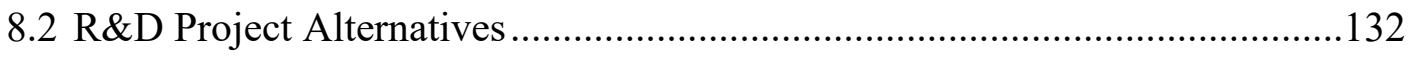

8.2.1 Identification of R\&D Projects to be Evaluated ..................................132

8.3 Alternatives Quantification Results ..............................................................141

8.3.1 Final Model Weights / Importance of Alternatives with respect to Mission 181

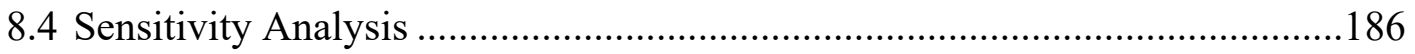

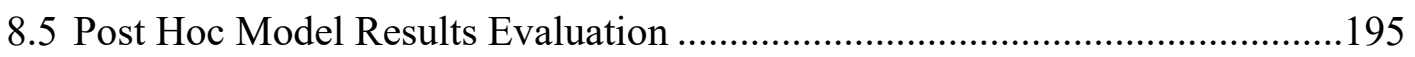

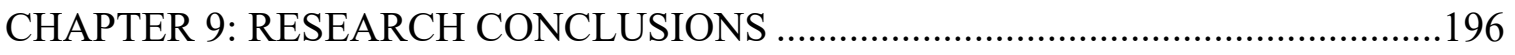

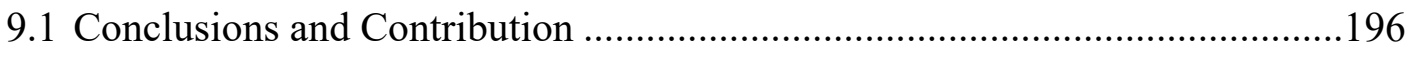

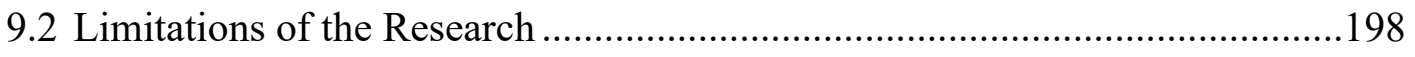

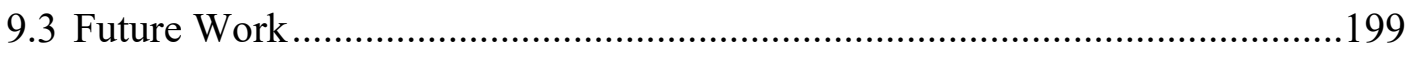

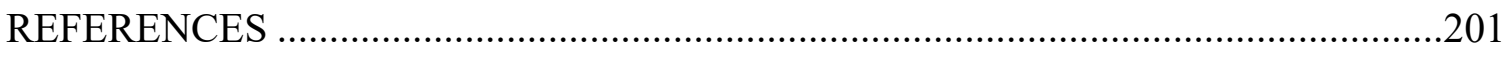

APPENDIX A: Research Instrument RI1: Criteria Decision Model Validation.............222

APPENDIX B: Research Instrument RI2: Sub-Criteria Decision Model Validation......224

APPENDIX C: Research Instrument RI3: Criteria Decision Model Quantification.......230

APPENDIX D: Research Instrument RI4: Sub-criteria Decision Model Quantification 234

APPENDIX E: Research Instrument RI4: Alternatives Decision Model Quantification236 APPENDIX F: Analysis of the Differences Between Criteria Normality Test of Criteria

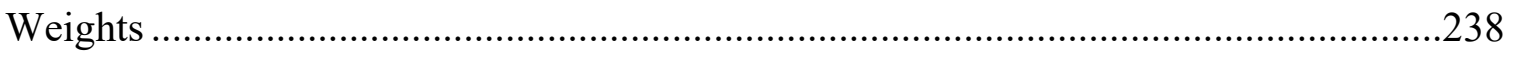

APPENDIX G: Q-Q plots for Normality Tests in Logarithms Values.............................239

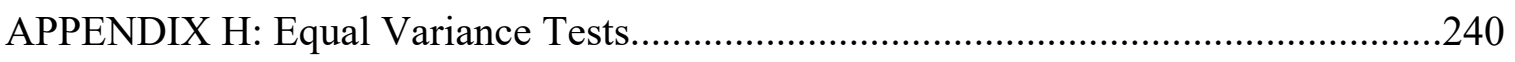

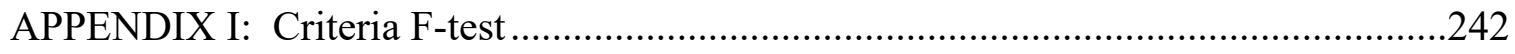




\section{LIST OF TABLES}

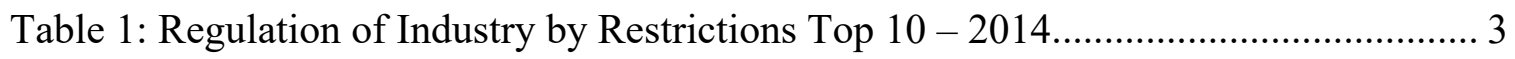

Table 2: R\&D Levels of Investment in the Electrical Power Sector ............................... 13

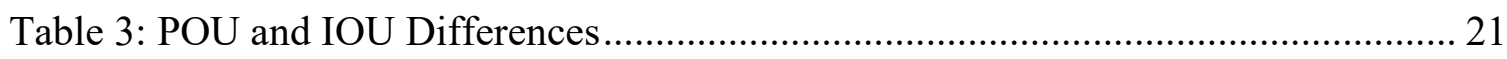

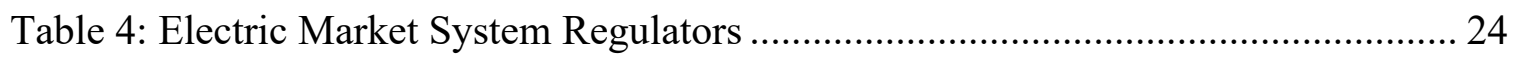

Table 5: Structure of the Electric Market in the United States ..................................... 33

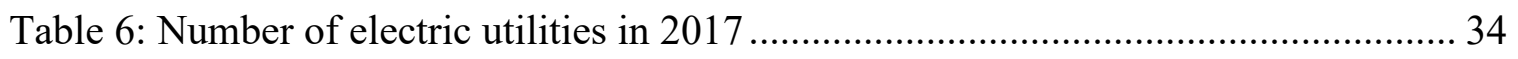

Table 7: Electric Market Conditions and Effects on R\&D investments ........................... 36

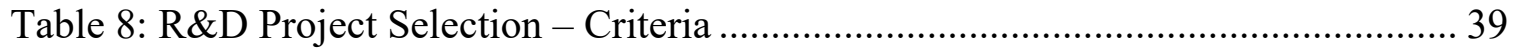

Table 9: (Tables A, B, ... L) - R\&D Project Selection - Sub-criteria............................ 41

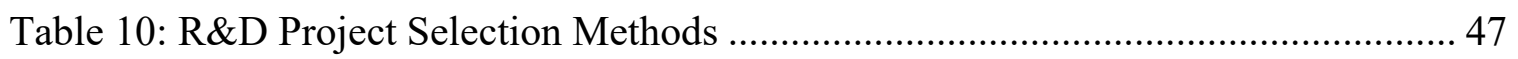

Table 11: Strengths and Weaknesses of Other Methods .............................................. 48

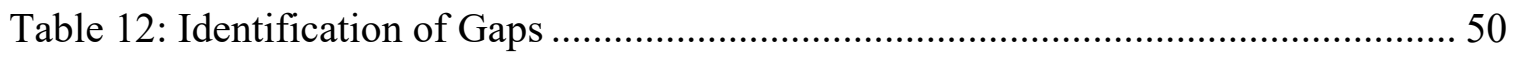

Table 13: Studies about Project and Portfolio Selection and Prioritization...................... 54

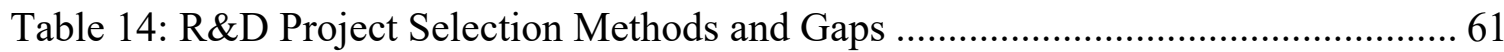

Table 15: Criteria and Sub-criteria According to Type of Organization .......................... 62

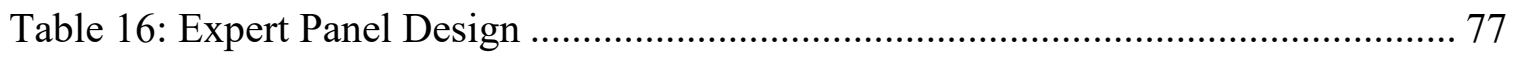

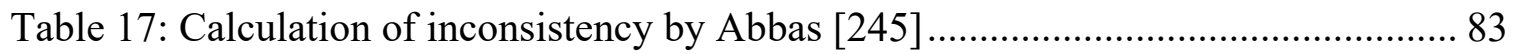

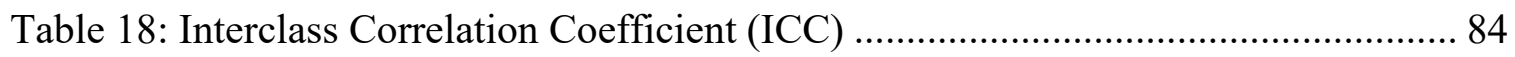

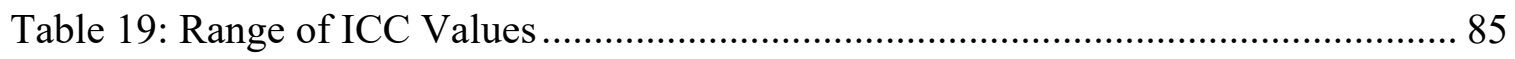

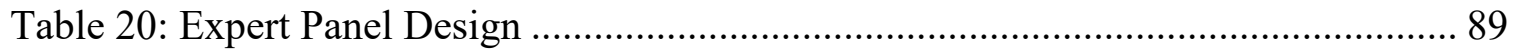

Table 21: Distribution of Experts for Validation and Quantification of the HDM ......... 90

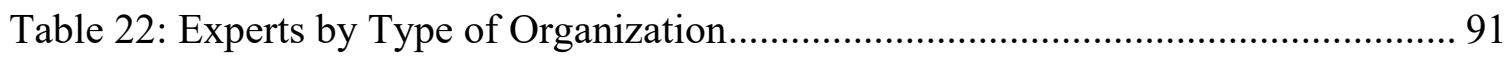

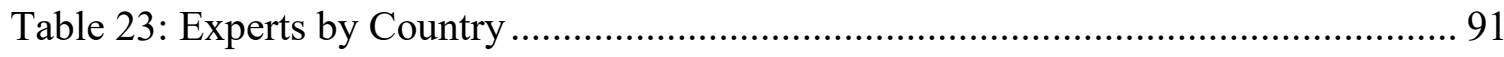

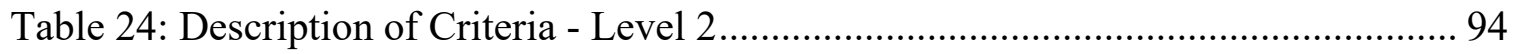

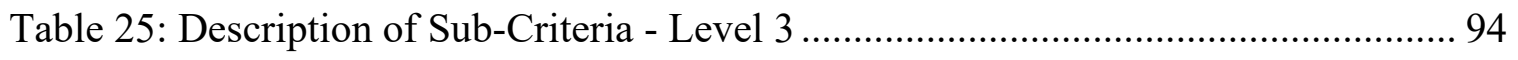

Table 26: Criteria Validation - Experts' Responses ................................................... 104

Table 27: Technical Criterion - Sub-Criteria Validation - Experts' Responses............. 105

Table 28: Market Criterion - Sub-Criteria Validation - Experts' Responses ................. 106 
Table 29: Organizational Criterion - Sub-Criteria Validation - Experts' Responses..... 107

Table 30: Economic Criterion - Sub-Criteria Validation - Experts' Responses ............ 108

Table 31: External/ Regulation/ Environmental Criterion - Sub-Criteria Validation Experts' Responses 109

Table 32: Relative Importance of Criteria ..................................................................... 114

Table 33: Relative Importance of Technical Sub-criteria........................................... 116

Table 34: Relative Importance of Market Sub-criterion.............................................. 117

Table 35: Relative Importance of Organizational Sub-criteria................................... 118

Table 36: Relative Importance of Economic Sub-criterion ....................................... 119

Table 37: Relative Importance of External/Regulation/Environmental Sub-criteria ..... 121

Table 38: Shapiro -Wilk and Shapiro -Francia Tests for Normality ........................... 123

Table 39: Kruskal-Wallis rank test Anova............................................................. 125

Table 40: Post-Hoc Pairwise Comparisons................................................................ 126

Table 41: BPA's Customers and Organization Type................................................ 128

Table 42: Business Information of the Power Marketing Agencies (PMAs) ................ 129

Table 43: R\&D Projects Selected Cluster - Results of Cluster Analysis....................... 136

Table 44: Information about the R\&D Project Alternatives to be Evaluated ................ 137

Table 45: Relative Importance of Alternatives Respect to Technical Success Sub-criterion

Table 46: Relative Importance of Alternatives Respect to Existence of Required Competence Sub-criterion ..... 143

Table 47: Relative Importance of Alternatives Respect to Availability of Resources Subcriterion 145

Table 48: Relative Importance of Alternatives Respect to Applicability to Other Products and Processes Sub-criterion ..... 146

Table 49: Relative Importance of Alternatives Respect to Technology Readiness Subcriterion 147

Table 50: Relative Importance of Alternatives Respect to Potential Size of Market Subcriterion 149 
Table 51: Relative Importance of Alternatives Respect to Time to Market Sub-criterion 151

Table 52: Relative Importance of Alternatives Respect to Additional (variety) applications opened Sub-criterion 152

Table 53: Relative Importance of Alternatives Respect to Market Risk Sub-criterion .. 154 Table 54: Relative Importance of Alternatives Respect to System planning Sub-criterion 156

Table 55: Relative Importance of Alternatives Respect to Research Staff Availability Subcriterion 157

Table 56: Relative Importance of Alternatives Respect to Knowledge/skill Availability Sub-criterion

Table 57: Relative Importance of Alternatives Respect to Competence and Experience on Similar Projects Sub-criterion. 160

Table 58: Relative Importance of Alternatives Respect to Strategic Fit Sub-criterion .. 162 Table 59: Relative Importance of Alternatives Respect to Available Facilities Sub-criterion 163

Table 60: Relative Importance of Alternatives Respect to Net Present Value (NPV) Subcriterion 165

Table 61: Relative Importance of Alternatives Respect to Value-added of Target Products Sub-criterion 166

Table 62: Relative Importance of Alternatives Respect to Project Cost Sub-criterion .. 168

Table 63: Relative Importance of Alternatives Respect to Economic Risk Sub-criterion 169

Table 64: Relative Importance of Alternatives Respect to Economic Regulations Subcriterion 171

Table 65: Relative Importance of Alternatives Respect to Environmental Policy Subcriterion 172

Table 66: Relative Importance of Alternatives Respect to Reliability, Resilience, State Awareness Technical Standards Sub-criterion 174 
Table 67: Relative Importance of Alternatives Respect to Acceptance of Stakeholders Subcriterion 175

Table 68: Relative Importance of Alternatives Respect to Power Quality Standards Subcriterion 177

Table 69: Summary of Weights / Importance of Alternatives with Respect to Each Criterion 178

Table 70: Final Model Weights / Importance of Alternatives with respect to Mission.. 182

Table 71: Synthesis of Priorities 183

Table 72: Overall Importance of Alternatives with Respect to the Mission..... 186

Table 73: Sensitivity Analysis with Technical dominant Criterion 187

Table 74: Overall Importance of Alternatives with Respect to the Mission 187

Table 75: Sensitivity Analysis with Market dominant Criterion 187

Table 76: Overall Importance of Alternatives with Respect to the Mission 188

Table 77: Sensitivity Analysis with Organizational dominant Criterion..... 188

Table 78: Overall Importance of Alternatives with Respect to the Mission 188

Table 79: Sensitivity Analysis with Economic dominant Criterion 188

Table 80: Overall Importance of Alternatives with Respect to the Mission 189

Table 81: Sensitivity Analysis with External/ Regulation/ Environmental Dominant Criterion 189

Table 82: Overall Importance of Alternatives with Respect to the Mission 189

Table 83: Summary of Case sensitive Analysis. 190

Table 84: Summary of Case sensitive Analysis - Weights..... 192

Table 85: Summary of Case sensitive Analysis - Ranks 192

Table 86: Post Hoc Model Validation 195 


\section{LIST OF FIGURES}

Figure 1: Regulation of Industries by Restrictions (top 10) - 2014 ............................... 3

Figure 2: Characteristics of Transmission Power Sector ................................................. 7

Figure 3: R\&D Project Selection- Evaluation Methods ................................................. 9

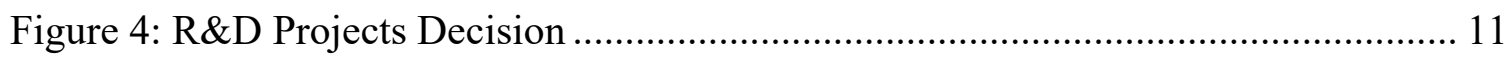

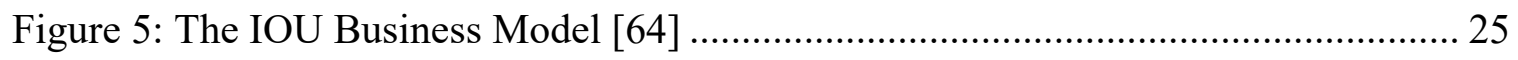

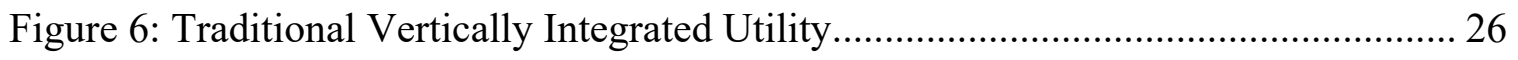

Figure 7: Traditional Vertically Integrated Utility with Wholesale Single Buyer........... 27

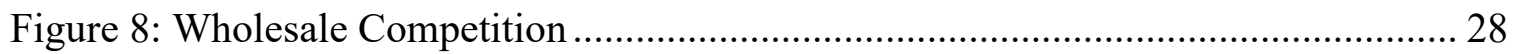

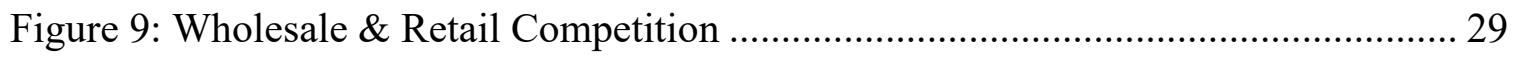

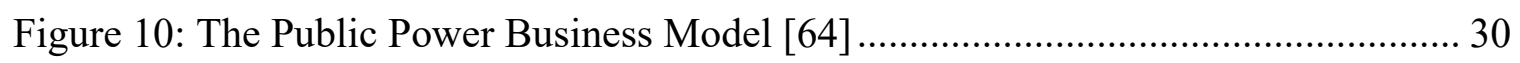

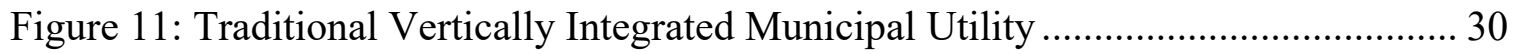

Figure 12: Generation \& Transmission + Distribution \& Retailer .............................. 31

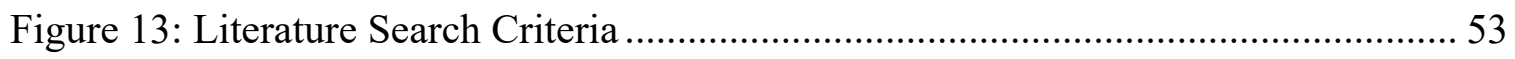

Figure 14:Studies about Project and Portfolio Selection and Prioritization .................... 56

Figure 15: R\&D Project Portfolio Selection Framework ........................................... 66

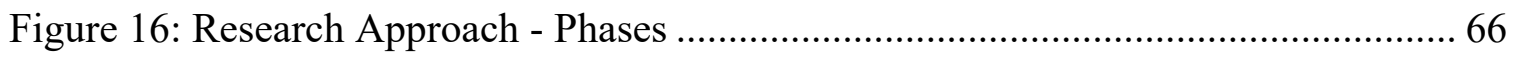

Figure 17: Model Development Phase - Literature Review - Research Application..... 68

Figure 18: Hierarchical Model Development ..................................................... 93

Figure 19: Integrating elements from Theoretical Models - Supporting Theories - Step 1 100

Figure 20: HDM Based on Literature Review and Theories ..................................... 102

Figure 21: Criteria Validation - Experts' Responses ............................................... 104

Figure 22: Technical Criterion - Sub-Criteria Validation - Experts' Responses ........... 105

Figure 23: Market Criterion - Sub-Criteria Validation - Experts' Responses................ 106

Figure 24: Organizational Criterion - Sub-Criteria Validation - Experts’ Responses ... 107

Figure 25: Economic Criterion - Sub-Criteria Validation - Experts' Responses ........... 108

Figure 26: External/ Regulation/ Environmental Criterion - Sub-Criteria Validation -

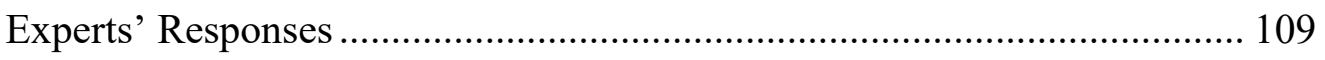


Figure 27: Pre-Validated HDM Model ................................................................... 110

Figure 28: Validated HDM by Experts - Levels 1, 2, 3 .......................................... 112

Figure 29: Relative Importance of Criteria ............................................................. 115

Figure 30: Relative Importance of Technical Sub-criterion ........................................... 116

Figure 31: Relative Importance of Market Sub-criterion .............................................. 117

Figure 32: Relative Importance of Organizational Sub-criterion .................................... 118

Figure 33: Relative Importance of Economic Sub-criterion......................................... 120

Figure 34: Relative Importance of External/Regulation/Environmental Sub-criterion .. 121

Figure 35: Graphical (histogram) Test for Normality.................................................. 122

Figure 36" Graphical (Box Plot) - Test for Normality ............................................... 123

Figure 37: Federal Power Marketing Administration Territories and Facilities............. 130

Figure 38: R\&D Project Clusters - Results.............................................................. 135

Figure 39: Final Validated HDM Model ............................................................ 140

Figure 40: Relative Importance of Alternatives Respect to Technical Success Sub-criterion 142

Figure 41: Relative Importance of Alternatives Respect to Existence of Required Competence Sub-criterion

Figure 42: Relative Importance of Alternatives Respect to Availability of Resources Subcriterion 145

Figure 43: Relative Importance of Alternatives Respect to Applicability to Other Products and Processes Sub-criterion..... 147

Figure 44: Relative Importance of Alternatives Respect to Technology Readiness Sub-

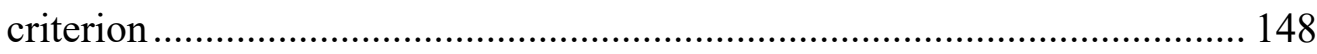

Figure 45: Relative Importance of Alternatives Respect to Applicability to Potential Size of Market. 150

Figure 46: Relative Importance of Alternatives Respect to Time to Market Sub-criterion 151

Figure 47: Relative Importance of Alternatives Respect to Additional (variety) Applications Opened Sub-criterion................................................................ 153

Figure 48: Relative Importance of Alternatives Respect to Market Risk Sub-criterion. 155 
Figure 49: Relative Importance of Alternatives Respect to System Planning Sub-criterion 156

Figure 50: Relative Importance of Alternatives Respect to Research Staff Availability Subcriterion 158

Figure 51: Relative Importance of Alternatives Respect to Knowledge/Skill Availability Sub-criterion

Figure 52: Relative Importance of Alternatives Respect to Competence and Experience on Similar Projects Sub-criterion. 161

Figure 53: Relative Importance of Alternatives Respect to Strategic Fit Sub-criterion 162

Figure 54: Relative Importance of Alternatives Respect to Available Facilities Subcriterion 164

Figure 55: Relative Importance of Alternatives Respect to Net Present Value (NPV) Subcriterion 165

Figure 56: Relative Importance of Alternatives Respect to Value-added of Target Products Sub-criterion 167

Figure 57: Relative Importance of Alternatives Respect to Project Cost Sub-criterion. 168 Figure 58: Relative Importance of Alternatives Respect to Economic Risk Sub-criterion 170

Figure 59: Relative Importance of Alternatives Respect to Economic regulations Subcriterion 171

Figure 60: Relative Importance of Alternatives Respect to Environmental Policy Subcriterion 173

Figure 61: Relative Importance of Alternatives Respect to Reliability, Resilience, State Awareness Technical Standards Sub-criterion 174

Figure 62: Relative Importance of Alternatives with Respect to Acceptance of Stakeholders Sub-criterion . 176

Figure 63: Relative Importance of Alternatives with Respect to Power Quality Standards Sub-criterion . 177

Figure 64: Summary of Weights / Importance of Alternatives with Respect to Each Criterion 180 
Figure 65: Summary of Case sensitive Analysis ................................................... 191

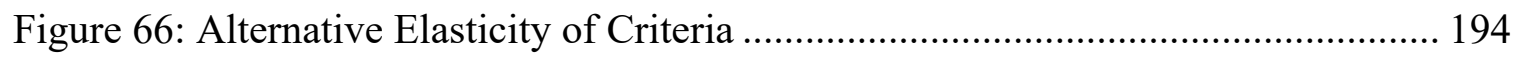

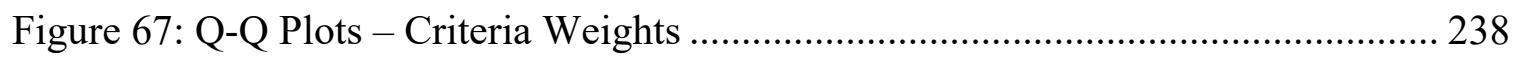

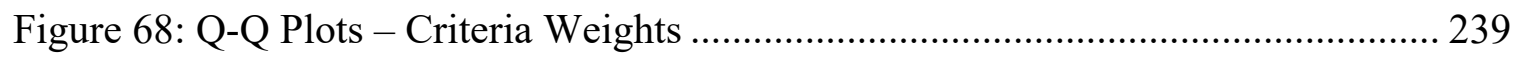




\section{LIST OF ABBREVIATIONS}

\begin{tabular}{|c|c|}
\hline AHP & Analytic Hierarchy Process \\
\hline ANP & Analytic Network Process \\
\hline BPA & Bonneville Power Administration \\
\hline $\mathrm{Co}-\mathrm{Ops}$ & Cooperatives \\
\hline DEA & Data Envelopment Analysis \\
\hline DLP & Dynamic Programming \\
\hline DSPs & Distribution Service Providers \\
\hline DSS & Decision Support Systems \\
\hline EP01 & Expert Panel 01 \\
\hline EP02 & Expert Panel 02 \\
\hline EP1 & Expert Panel 1 \\
\hline EP2 & Expert Panel 2 \\
\hline ERCOT & Electric Reliability Council of Texas \\
\hline FERC & Federal Energy Regulatory Commission \\
\hline GP & Goal Programming \\
\hline HDM & Hierarchical Decision Model \\
\hline ICC & Interstate Commerce Commission \\
\hline ICC & Interclass Correlation Coefficient \\
\hline IOUs & Investor-owned Utilities \\
\hline Ip & Integer Programming \\
\hline IRP & Integrated Resource Planning \\
\hline IRR & Internal Rate Return \\
\hline ISOs & Independent System Operators \\
\hline LP & Linear Programming \\
\hline MAUT & Multi-attribute Utility Theory \\
\hline NERC & The North American Electric Reliability Corporation \\
\hline NLP & Non-linear Programming \\
\hline
\end{tabular}




$\begin{array}{ll}\text { NPV } & \text { Net present value } \\ \text { POUs } & \text { Publicly-owned Utilities } \\ \text { PURPA } & \text { Public Utility Regulatory Policy Act } \\ \text { QBA } & \text { Q-Sort, behavioral decision aids } \\ \text { R\&D } & \text { Research and Development } \\ \text { RI1 } & \text { Research Instrument 1 } \\ \text { RI2 } & \text { Research Instrument 2 } \\ \text { RI3 } & \text { Research Instrument 3 } \\ \text { RI4 } & \text { Research Instrument 4 } \\ \text { ROI } & \text { Return on Investment } \\ \text { RTOs } & \text { Regional Transmission Organizations } \\ \text { SNA } & \text { Social Network Analysis } \\ \text { SWARA } & \text { Weight Assessment Ratio Analysis } \\ \text { TIP } & \text { Technology Innovation Project } \\ \text { TSPs } & \text { Transmission Service Providers }\end{array}$




\section{CHAPTER 1: INTRODUCTION}

\subsection{Research Motivation}

Research and Development (R\&D) is relevant for economic growth and for being a factor determining the competitiveness and success of companies in the long run. Additionally, $\mathrm{R} \& \mathrm{D}$ is decisive for improving existing technologies and promoting innovation. The demand for technology improvements creates a demand for R\&D, which generates better profits for organizations, and also lower costs, lower prices, and betterquality products and services for consumers. These benefits for organizations and customers align with long-term policies [2].

Investment in the transmission power sector is related to the complexity of decisions, especially investing in $\mathrm{R} \& \mathrm{D}$ projects. The decision to invest in $\mathrm{R} \& \mathrm{D}$ projects is affected by many factors, including regulations and scarce resources. Furthermore, investments for generating and transmitting electricity by utilities are associated with market needs, government policies and regulations, technical capabilities, and economic optimality. In this context, $R \& D$ is recognized as an important part of an organization's market strategy [3], [4]; however, R\&D project selection is a complex decision [5], [6], [7], [8], [9], [10], [11], [12], [13] as it often can be inconsistent [14].

Even though investments in R\&D are low in regulated non-profit organizations, due to associated risks [15] and not realizing full-benefits [1], the importance of selecting and evaluating $R \& D$ investment projects is related to the acquisition of internal and external technologies. Accordingly, organizations need to evaluate and select the most 
relevant projects at a starting point as a part of their strategies to accomplish their organizational objectives, because it is challenging to evaluate projects once they have begun. Furthermore, investments in R\&D are not only important for companies or organizations but the entire region[16], and more so in the specific case of electric utilities since energy and electricity directly affect the economic progress. For these reasons, the keys of reviewing and prioritizing projects are based on prioritizing resource allocations aligned with the strategies of the organization [17].

Power transmission utilities interact with both power generators and distributors, playing the role of transmitting electricity to the load centers and determining the structure of electric power markets. In this context, electrical business structures and business models are influenced by the role of transmission utilities. These characteristics, along with public, non-profit, and regulated conditions, define the business environment. Therefore, it is crucial to analyze these characteristics because they are primarily related to $R \& D$ project selection.

R\&D project selection in organizations that are under regulations needs to be analyzed because of the high impact of regulations on decision making. High levels of regulation are related to changes in the entire economy, such as inducing low entrepreneurship, impacting changes in the allocation of investments, and affecting diminishing labor productivity growth [18]. Consequently, there is a need to identify and consider the factors associated with regulated organizations in order to evaluate $R \& D$ projects to select the projects that will optimize the received benefits of all sectors and stakeholders. Selecting the right projects will reduce the risk of negatively affecting the 
sectors involved in the industry. McLaughlin \& Sherouse [18] explain the importance of the electric sector in the context of regulation. This study used the number of restrictions linked to each industry, showing that the electric power industry, including transmission, is highly regulated (see Table 1 and Figure 1):

Table 1: Regulation of Industry by Restrictions Top $10-2014$

\begin{tabular}{|l|c|}
\hline \multicolumn{1}{|c|}{ Industry } & Number of Restrictions \\
\hline Petroleum and Coal Products Manufacturing & 25482 \\
\hline Electric power Generation, Transmission, and Distribution & $\mathbf{2 0 9 5 9}$ \\
\hline Motor Vehicle Manufacturing & 16757 \\
\hline No Depository Credit Intermediation & 16579 \\
\hline Depository Credit Intermediation & 16033 \\
\hline Scheduled Air transportation & 13307 \\
\hline Fishing & 13218 \\
\hline Oil and Gas Extraction & 11955 \\
\hline Pharmaceutical and Medicine Manufacturing & 11505 \\
\hline Deep-Sea, Coastal, and Great Lakes Water Transportation & 11279 \\
\hline
\end{tabular}

Source: [18]

\section{Regulation of Industry by Restrictions}

Top 10 - 2014
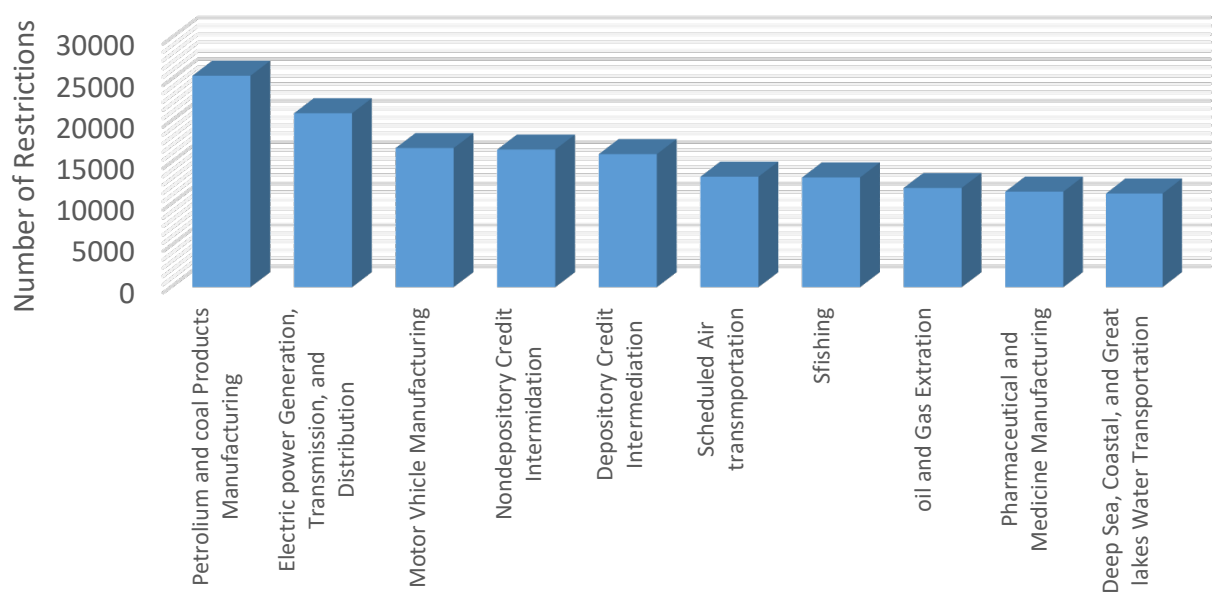

Figure 1: Regulation of Industries by Restrictions (top 10) - 2014 Source: [18] 
There is a lack of studies focusing on the ex-ante evaluation of R\&D projects in organizations that are considered as public, non-profit, and regulated by the government, especially in the case of power transmission utilities (see the literature review section). It is needed to formulate an integrated multi-criteria evaluation, because regulated systems and R\&D projects are associated with public interest and multiple factors (in addition to financial aspects).

This research is focused on Research and Development (R\&D) project selection and the identification of criteria and sub-criteria to select the best set of projects for investment in a regulated transmission electric utility [3]. The methodology considered in this research is framed into a Hierarchical Decision Model (HDM) since it allows for the holistic consideration of all factors. Therefore, the main contribution of this research is the identification of criteria and sub-criteria in a holistic view. In addition to the methodological aspects to validate the information, the HDM allows researchers to identify and quantify the critical aspects to be considered.

\subsection{Research Background}

This study provides a pre-screening framework (ex-ante) regarding two aspects: It provides information about the most relevant criteria and sub-criteria associated with $R \& D$ projects before investing in it. It also provides an evaluation process for R\&D projects in the power sector. Particularly, the research is focused on public, non-profit, and regulated organizations. 
There is a lack of studies framing their analysis around electrical utilities that holistically consider all of the factors. Together, the lack of studies and the fact that experts may not fully consider all of the factors, represent an opportunity for the present research to have a detailed analysis of all the factors linked to R\&D investments in the power transmission sector. Accordingly, the framework of the research is focused on evaluating new $R \& D$ projects, the identification of criteria and sub-criteria affecting the evaluation objectives, and finding the ranking of the projects.

\subsubsection{Problem Statement}

Decisions for selecting R\&D projects are complex since there are many associated factors, including uncertainties, the interdependence between the projects, budgets constraints, and characteristics of the life cycle of projects and technologies [19], [20], [21]. $R \& D$ decisions are made under high uncertainties since investments in the electrical sector are associated with regulations, environmental concerns, and external factors [22], [23], [19], [9]. Government policies affect the energy market of technologies [15] because adapting to new regulatory conditions influences the $R \& D$ investment levels inducing organizations to decrease their investment portfolios. Moreover, changes in the U.S. power market and the different regulatory policies followed in each state increase the business uncertainties, which negatively influence utilities to adapt to new conditions [16]. Because of the limited funding and resources and all factors associated with $R \& D$ projects, the selection needs to be done efficiently at a starting point [3], [24], [20]. 
The identification of all factors associated with $R \& D$ projects requires comprehensive knowledge and understanding of technical aspects, organizational strategies, market conditions, and regulations. Nevertheless, identifying these factors is subject to difficulties and challenges, such as the dual role of experts in developing and implementing technologies, a variety of market conditions, and lacking adjustability to changes [25]. The use of experts, who do not fully understand these important factors, can cause a misidentification in the decision-making process.

The characteristics of $R \& D$ project investments in public and private organizations are different. Electric transmission utilities are different because they are driven by their natural monopoly characteristics, by regulations, by their public and non-profit nature, by different technical and business operation environments, and by different market conditions. In this context, $\mathrm{R} \& \mathrm{D}$ project selection in regulated organizations needs to accomplish market, contractual, or regulatory needs [26], [24]. Specifically, Transmission electric utilities are considered non-profit organizations that are regulated by governments, implying that investments are associated with many factors and interested stakeholders' influences. Because of this public nature of electric transmission utilities, the government funds $R \& D$ by using pure government funds or collaborating with private organizations [15]. Moreover, governments often planned R\&D investments for long-term goals making $R \& D$ selections difficult because of the ambiguity of innovative technologies and lack of experts. Consequently, solely using financial evaluation methods can be considered inadequate [27] and evidencing the need to have a different portfolio management technique [26], [24]. 
From an organizational perspective, the principles for the $R \& D$ regulation entail selecting projects linked to uncertainties, multiple objectives, and organizational strategies. However, selected R\&D projects can be associated with technologies that do not align with the objectives of the organizations, and are suitable for projects considered a public interest. Consequently, the effects of regulating R\&D investments by utilities are associated with allowed levels of investments, speed of innovations, nature of the innovations, and management of projects [28].

The complex structure of the transmission utilities is shown in Figure 2. It is observed that the natural conditions of electric transmission utilities are associated with regulation and are considered as non-profit and public organizations. At the same time, the most important congruent factors affecting these types of organizations are technical characteristics, business operations, and market conditions. The nature of the large investments and the limited budget to be invested affect the entire operation of these organizations.

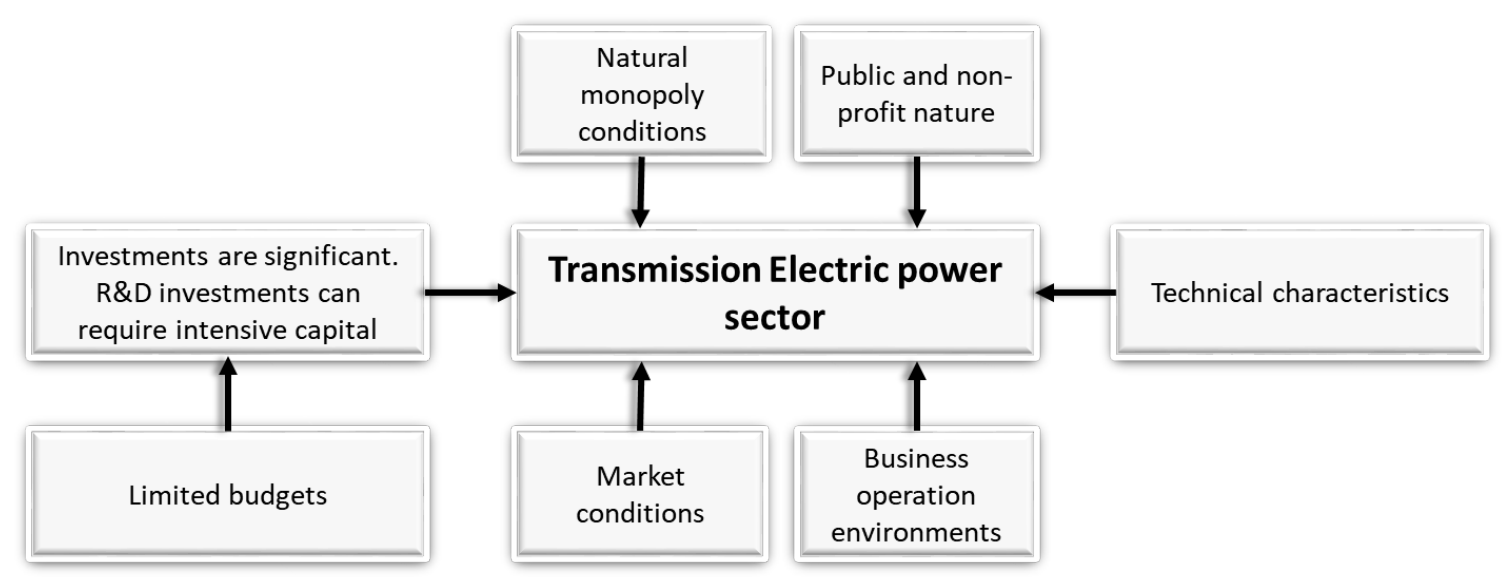

Figure 2: Characteristics of Transmission Power Sector 
The long-term investments are characteristics of complex systems that require simultaneous analysis of sub-systems, implying optimal selections of portfolios [26]. As a result, organizations need to select projects that contribute to long-term competitiveness [29]. A deficient selection of projects can cause an ineffective portfolio since the methods used are based on a systematic selection of individual projects and not for the entire portfolio. Thus, the R\&D project selection process needs to consider the selection of $R \& D$ projects and portfolios under organization strategies, stakeholders' perspectives, and the qualitative benefits and risks of the projects [12]. Strategic objectives are also needed in project selection since any decision implies future financial aspects and the ability to compete with different technologies [30], [7]. This process involves many steps, stakeholders (multiple decision-makers), multiple criteria, multiple choices with different objectives, and uncertainties [10], [31].

Project selection and portfolio analysis depend not only on a particular project characteristic, but on a broader context considering profitability, strategy, uncertainty, and social aspects [29]. However, managers see projects as a unique opportunity to invest and often are not willing to consider the whole portfolio because of the complexity of R\&D projects. Furthermore, organizations can lack experts who have sufficient knowledge to analyze specific $R \& D$ projects [32]. Since each $R \& D$ project is new and not identical, project evaluations that depend on experts' opinions can be influenced by their experience and knowledge about the technology.

Tools and methodologies used by organizations are limited because they do not fully capture the particular characteristics of R\&D projects focused on electric power 
systems. Evaluation methods for R\&D projects treat the interrelations between projects inadequately and do not consider the interrelation of multiple criteria and sub-criteria [33], [34]. Additionally, the complexity of the existing methodologies makes it difficult to incorporate them into the process of technology selection and to help decision-makers [9]. The R\&D investment decision methods are complex and cannot be easily developed by managers [35] since some methods use complex mathematical models that cannot be applicable in real situations [19]. Therefore, companies need practical tools that help optimize R\&D project selection [10]. The figure below summarizes the inadequacy of evaluating methods:

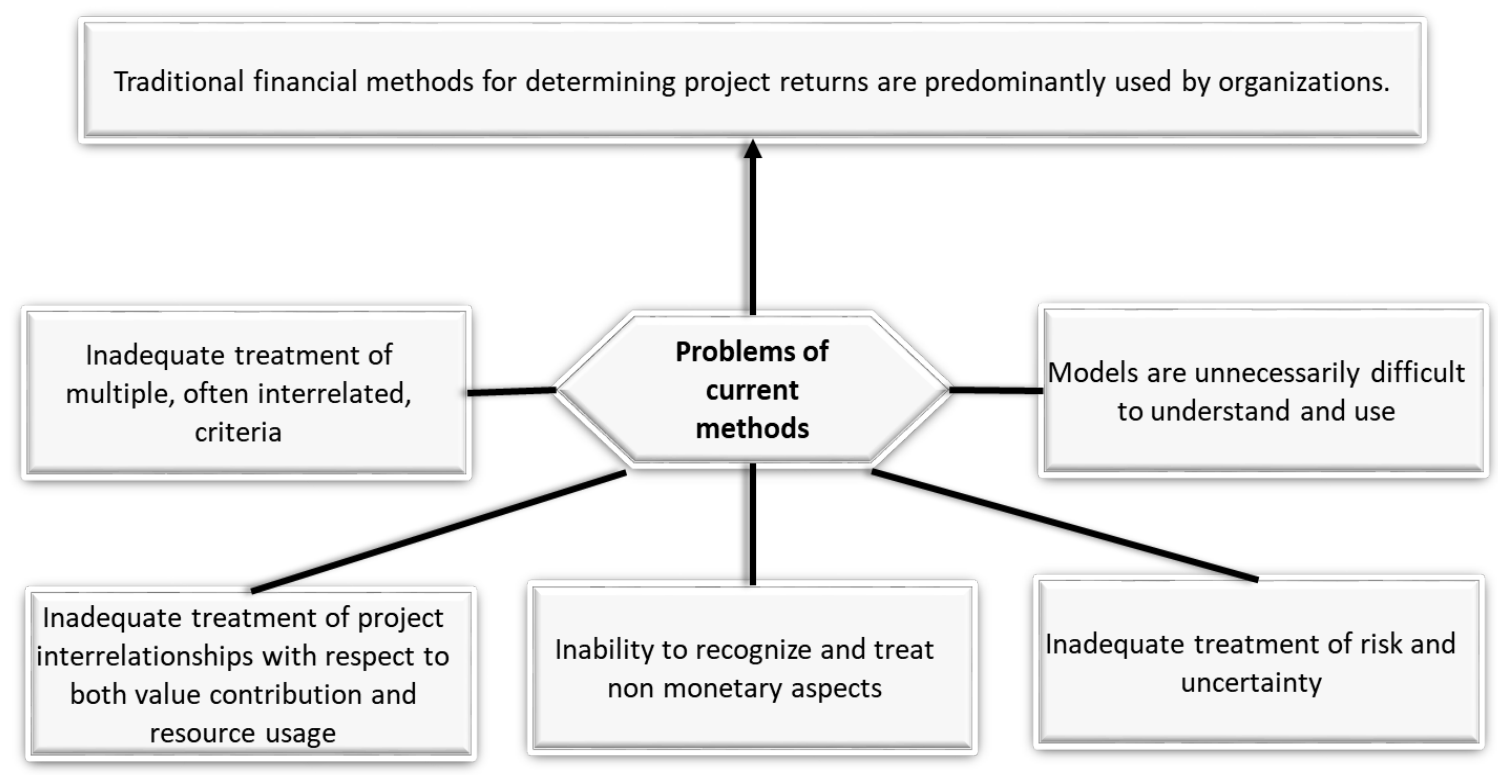

Figure 3: R\&D Project Selection- Evaluation Methods

Another inherent problem in evaluating $R \& D$ projects is the availability of information for making decisions at specific points of the project development [36]. Data emerges gradually during that time and as a consequence, the initial estimations of cash 
flow for a study period frequently show unreliable evaluation results [13]. This disadvantage of the models by evaluating $\mathrm{R} \& \mathrm{D}$ projects by discount cash flow has been criticized by many scholars, such as Hassanzadeh et al., Nagm and Kautz, Liberatore and Titus, Amaro et al., and Cooper and Edgett [22], [37], [38], [39], [34]. These authors indicate that financial methods use quantitative financial analysis, failing to value the qualitative aspects since financial analysis is effective when data is estimated with some certainty. The sophistication and complexity of financial models involve a large amount of data; however, reliable data is usually available when projects are already in the commercialization stage. By solely using financial methods, the experts' judgments are ignored during the evaluation process [40]; even these judgments are important for objectively evaluating the projects. 


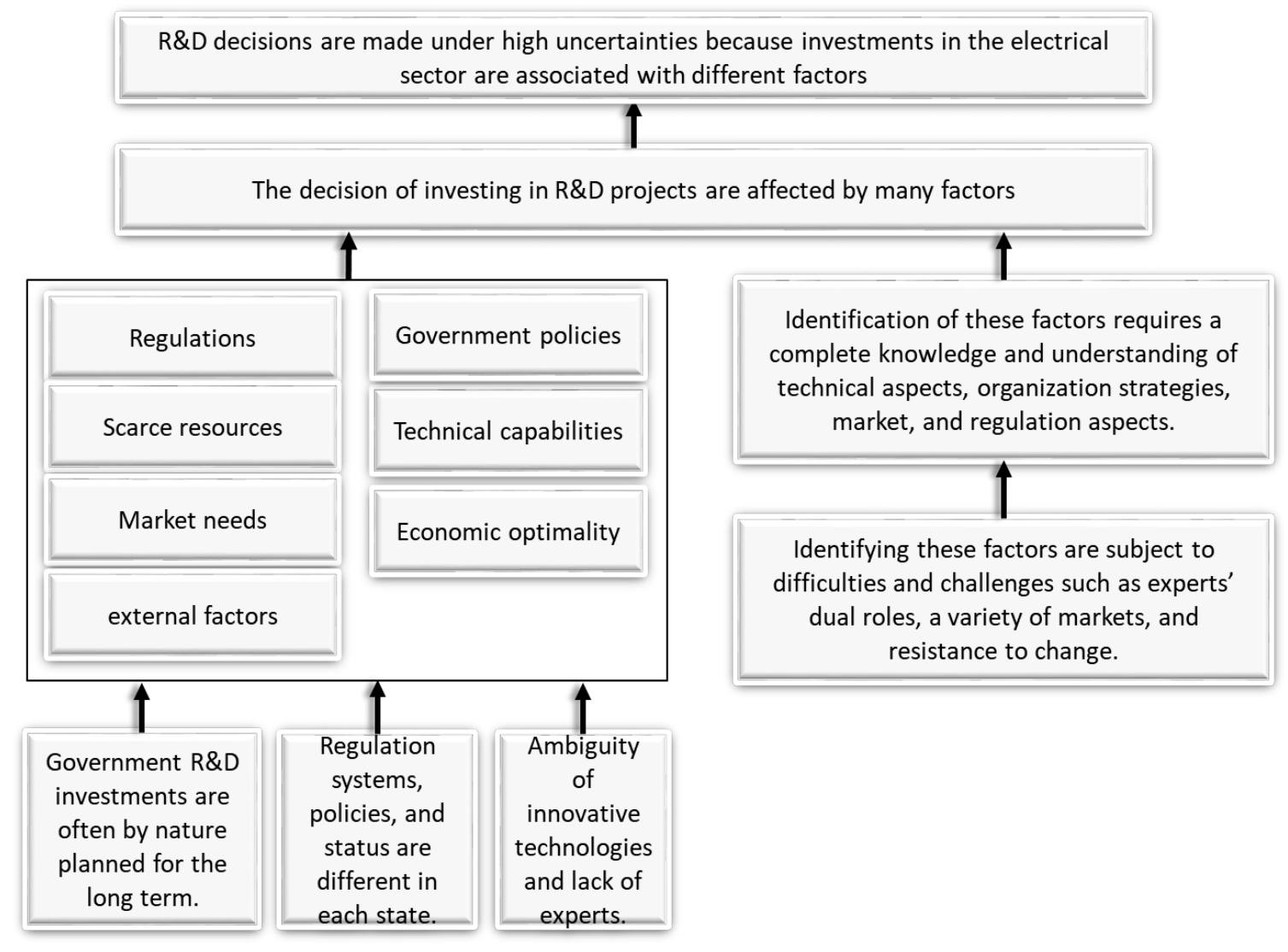

Figure 4: R\&D Projects Decision

The following figure shows the complexity of interacting factors on deciding on R\&D investments in electric transmission utilities. As can be seen below, the uncertainties involving the R\&D investment in electric transmission utilities are present in the entire evaluation of the R\&D projects. On the one hand, there are many factors (criteria) and stakeholders affecting the decision; on the other hand, the presented difficulty of identifying the factors determines the importance of integrating all of the criteria for evaluating R\&D projects (see figure below). 


\subsubsection{R\&D Levels of Investment in the Electrical Power Sector}

The R\&D investment in the United States has decreased in general, even with numerous concerns about the environment, geopolitical, or economic situations. In the specific case of energy, R\&D investments declined $6 \%$ while the R\&D investment in general in the United States grew by $10 \%$ to $15 \%$ per year during the last twenty years. The lower levels of R\&D investments are attributed to the lower funding to fossil fuel, as well as the deregulations of markets that reduce the incentives for collaboration and uncertainties in regulatory policies. Changes in the policies and the corresponding uncertainties affect the investments and discourage investment [41], [42]. Furthermore, not all electrical utilities have the same pattern. Newly privatized utilities tended to decrease their R\&D investments, which is contrary to utilities that remained under government control. Consequently, regulation and deregulation of markets affect the levels of R\&D investments [42].

In deregulated markets, the competition generates cost reductions, affecting $R \& D$ investments. At the same time, $R \& D$ projects related to general-purpose technologies are not considered since they related to long-term periods [42]. However, in other countries different from the United States, R\&D investments have increased; electrical utilities in Europe have increased their R\&D investments by promoting incubators, accelerators, and innovative start-ups [43]. Therefore, regulated organizations find R\&D activities positive.

According to the U.S. Department of Energy (EIA Table 2) there has been an increase of the levels of R\&D investments by the U.S. government from 2010 to 2013 [44]. 
These investments have focused on the transmission system and its improvements in reliability.

Table 2: R\&D Levels of Investment in the Electrical Power Sector

\begin{tabular}{|c|c|c|}
\hline Fuel/End Use, Department, and Program - CFDA Number (million \$) & $\begin{array}{c}\text { FY } \\
2010\end{array}$ & $\begin{array}{c}\text { FY } \\
2013\end{array}$ \\
\hline Electricity - Smart Grid and Transmission & 534 & 831 \\
\hline Department of Energy & 530 & 827 \\
\hline Advanced Research Projects Agency - Energy Financial Assistance Program - 81.135 & 1 & 10 \\
\hline $\begin{array}{l}\text { Electricity Delivery and Energy Reliability, Research, Development, and Analysis - } \\
81.122\end{array}$ & 497 & 791 \\
\hline Renewable Energy Research and Development - 81.087 & 33 & 27 \\
\hline National Science Foundation & 4 & 4 \\
\hline Engineering Grants - 47.041 & 4 & 4 \\
\hline $\begin{array}{l}\text { Conservation } \\
\text { Advanced Research Projects, Conservation, Renewable Energy, Engineering Grants }\end{array}$ & 610 & 501 \\
\hline $\begin{array}{l}\text { Other (End-Use) } \\
\text { Advanced Research Projects, Geologic Sequestration, Renewable Energy, Surveys, } \\
\text { Studies, Research, Investigations, Demonstrations, and Special Purpose Activities } \\
\text { Relating to the Clean Air Act - 66.034, Engineering Grants }\end{array}$ & 427 & 466 \\
\hline Total & 3,473 & 3,491 \\
\hline
\end{tabular}

Source: [44]

\subsection{Research Overview}

The research method is framed in the context of the $R \& D$ project investment evaluation. In order to accomplish the objectives and answer the research questions, a multi-criteria analysis, Hierarchical Decision Model (HDM) - Analytic Hierarchy Process (AHP) is applied. The model is built under technology adoption concepts and then applied 
to the power sector. This research analyzes the factors, including risk presented in new technologies in power utility.

The analysis is divided into three categories: 1) Criteria identification, 2) Subcriteria identification, 3) Alternatives identification, and case application. In order to identify the criteria and sub-criteria, theoretically based models in a firm-level context have been identified and analyzed as they are presented in the following items. The criteria correspond directly and strictly to theoretical fundamentals, while sub-criteria are based on theoretical and practical studies. Risk sub-criteria are intrinsically incorporated, adapted, and based on the theoretical foundations of Fonslow et al. [45] by including risk sub-criteria explicitly in each criterion.

\subsubsection{Research Objectives and Contributions}

This research provides an $R \& D$ project selection analysis based on an $R \& D$ project assessment model that can support strategic decision-making for regulated electrical transmission utilities. The applied methodology is based on HDM (AHP) that allows a breakdown of large unstructured decision problems into a more flexible structure to measure their components. Additionally, the methodology and results of this study create a better and clear idea of the factors associated with the analysis of $R \& D$ projects, clarifying and correcting the contradictory and heterogeneous results when different other methodologies are applied. An HDM-R\&D project portfolio selection is used to evaluate the R\&D projects' opportunities, accomplishing the following objectives: 


\section{Main objective:}

To develop a model to select $\mathrm{R} \& \mathrm{D}$ projects based on a holistic approach aligned to strategies, utility objectives, and market conditions in the regulated electric transmission sector.

\section{Specific objectives:}

- To identify the factors (criteria and sub-criteria) associated with R\&D projects in the transmission power sector.

- To quantify and weight the levels of factors (criteria and sub-criteria) for investing in $R \& D$ projects in the power transmission sector, and to decide the best option for each project.

- To categorize factors for adopting the R\&D project selection in the power transmission sector. 


\section{CHAPTER 2: LITERATURE REVIEW}

The literature review is focused on characterizing public and regulated organizations in the context of selecting $R \& D$ projects in electric transmission utilities. Three important aspects frame this literature review. First, to understand the importance of the transmission sector, an overview of the power market is provided, including the description of the evolution of power markets. It shows the importance of power transmission utilities in business models, including regulated and deregulated systems. Second, it is necessary to define the concepts of utility and public and private organizations. These concepts are discussed, followed by the identifications of the types of utilities. Theoretical business models in the power market and the importance of the transmission sector are described to identify the types of utilities and business models. After identifying the types of utilities and the business models, complete and detailed information and structure of the power market are provided and summarized. This part includes the transmission sector (the description of the transmission sector was prioritized) and also provides information about the whole electric market due to the importance of the transmission utilities in the market and the interaction with other utilities. This information is important to analyze the generalization of the HDM model and the adaptation to different types of organizations. Third, the study discusses the effects of different regulation systems on R\&D investment. Specifically, the study analyzed the case of regulated and deregulated sectors of the electric power market. Finally, project selection methods and the factors associated with R\&D project selection are described. 


\subsection{Market Structure of Power Systems}

The electricity market has changed during the last decades, especially since 1990. The restructuration and changes in the power industry were in the U.S around the world were to move from vertically integrated systems to competition systems [46], [47]. Electric utilities that generate, transmit, and distribute energy have been considered natural monopolies, regulated under the public authority, and planned and operated by the integrated resource planning (IRP) [48], [49], [50]. In 1978, the Public Utility Regulatory Policies Act (PURPA - 1978) stopped the monopoly in that generation and allowed them to be independently-owned investors that could purchase electricity from qualifying facilities (Q.F.'s) [49]. The transition to the deregulated industry has changed the market model, where generation and transmission are planned and operated by different companies. The changes started in the 1990s by allowing competition in the generation sector and by using wholesale markets. Since many states legislated the competition in the electricity markets, there has been an increasing number of independent, non-utility power producers and the imperative interaction with the wholesale markets by using the interstate transmission lines (operated by transmission organizations or independent system operators). Additionally, many states have separated the generation, transmission, and distribution systems [47].

Separation of the three sectors (generation, transmission, and distribution) for restructuring the power market has been complicated. In the specific case of the transmission sector, it was necessary to separate the ownership and control to have fair and non-discriminatory access to the transmission services [46]. 
The U.S. electricity sector and principally, the transmission sector, which is associated with a variety of factors, determines the management and operation of the power system. These factors include the changes in the type of generation sources and technologies, changes in the load growth, and regulations by federal, state, and local governments [51]. Therefore, under the current order and regulatory conditions, the electricity market is determining changes in the traditional business models since utilities need to align to the new conditions and keep or increase sale levels in a field of competitive conditions and increasing costs [52].

The transition from regulated systems to deregulated systems has been done in many states in the United States with different results. Wholesale electricity markets are still regulated by the Federal Energy Regulatory Commission (FERC) under the authority granted by the 1938 Federal Power Act. The restructuring of the transmission area has played an important role in moving to deregulation systems because transmission is the link between generators and distributors, granting access to competitive sellers [53].

According to Borenstein and Bushnell [53], the transmission restructuring had two paths:

- Regulatory path: Related to rules upon vertically-integrated utilities allowing thirdparty companies access to the network.

- Institutional path: Creation of Independent System Operators (ISOs) and Regional Transmission Organizations (RTOs). 


\subsubsection{Definition of Utility}

A general definition of utility is that utilities are entities that provide commodities or services which are necessary. Due to the vital need, utilities and related services are regulated by federal, state, and local authorities to avoid over pricing, granting accessibility. At the same time, utilities have some monopolistic rights. Federal regulations point to the interstate wholesale transactions, while state regulation points to the level of consumers or distribution [54], [55].

A more specific definition of utilities is regarding electric public utilities. A public utility is referred to as an organization that operates facilities at the level of interstate commerce. At the same time, interstate commerce is referred to as wholesale. In this case, the Federal Energy Regulatory Commission (FERC) has regulated the interstate wholesale of electricity [56].

As indicated above, the electric utility is divided into three main functions: generation, transmission, and distribution. Although a small number of electric utilities in the United States performed all three functions together, most of the utilities are considered investor-owned utilities (IOUs), which own generation, transmission, and distribution facilities. There are few publicly-owned utilities (POUs) that own a transmission or generation installation [54].

To understand the functions and differences between these two types of organizations, publicly-owned utilities (POUs) and publicly-owned utilities (POUs), a description of the private sector and public sector are provided below. 


\subsubsection{Types of Utilities}

Utilities are different in each state and federal legislation. In general terms, there are two types of utilities: Private (investor-owned utilities - IOUs) and public (publicowned utilities - POUs) [55]. Below are described these two types of electric utilities focusing on "public utilities" since wholesale marketers are in this group. However, a detailed description of IOUs is provided because organizations such as RTOs and ISOs transmit high voltage power energy and have similar objectives as Bonneville Power Administration (BPA).

The main characteristic of the private sector is that the organizations are privately owned and are not part of, or operated by, the government. The organizations are mostly corporations that can have a profit or non-profit objective, which is contrary to the public sector formed by organizations owned and operated by the federal, state, or municipal governments [57], [55]. In the 1990s, private companies were considered investor-owned vertically-integrated monopoly utilities (IOU) that provided generation, transmission, and distribution. These IOUs were regulated at a state level [53].

The electric utilities can be considered private or public organizations. The public utilities are non-profit organizations that own and operate their installations to benefit consumers. These types of utilities are different from private utilities (investor-owned utilities, or IOUs) which are for-profit organizations and look for financial benefits [58].

The POUs are subject to control by local, state, or federal authorities. As it is detailed in Table 3, POUs include municipal districts or rural cooperatives, among others. 
The main differences between the publicly-owned and investor-owned utilities are summarized by [59] in the following table:

Table 3: POU and IOU Differences

\begin{tabular}{|c|}
\hline POU \\
\hline $\begin{array}{l}\text { - Their mission is focused to "optimize benefits for local customer-owners," for example, } \\
\text { through lower energy rates. } \\
\text { - The ownership is generally limited to the service area and integrated by the government and } \\
\text { customers. } \\
\text { - Structurally, POUs are considered as non-profit public managed by locally elected officials } \\
\text { and public employees. } \\
\text { - The rates are determined by bodyboard or city council in each utility and public forum. } \\
\text { The profits are obtained from rates levels that consider costs and additional returns. The } \\
\text { returns are for keeping ratings of bonds and build new facilities. }\end{array}$ \\
\hline IOU \\
\hline $\begin{array}{l}\text { - Their mission is focused on "to optimize return on investment" of investors. } \\
\text { - } \text { Ownership is not limited to the service area and integrated by shareholders or investors. } \\
\text { - Structurally, IOUs are private companies and managed by shareholders (elected board). IOUs } \\
\text { are regulated by the Public Utilities Commission (PUC). } \\
\text { - } \quad \text { Rates are determined and regulated by the Public Utilities Commission (PUC), with are public } \\
\text { and with customer participation. } \\
\text { - Profits cover costs and returns, which include investment risks. }\end{array}$ \\
\hline
\end{tabular}

Source: [59]

\subsubsection{Characteristics of Public Utilities}

Public utilities serve consumers providing the service at acceptable rates, establishing reasonable prices, and considering the levels of demand and levels of returns. The type of utilities are monopolies in an area and are regulated (under federal or state legislation), receiving the rights to maintain the service level. The demand for the service will always exist; therefore, there is no risk for competing due to the monopoly conditions. Because 
the nature of natural monopolies corresponds to high capital investments, the participation of small investors is limited. These investments are considered more in fixed assets [60].

R\&D in the utility industry is considered as public interest since the benefits are received by residents, and are not possible to be addressed by a competitive market [61]. Power transmission can be considered as public good since who receive the benefits are widespread in long time periods, relating to large infrastructure investments that correspond to regional planning, and implies the recovery of costs [62].

\subsubsection{Transmission Utility Regulation}

An important topic to be described is the reason for regulating the electric transmission utilities. Warwick and Stinson [55] and [56] define regulation in utilities as the act of controlling utility operations and finances, and can be seen as a substitute for weak competition. To protect the "public interest," [63] and to minimize or eliminate the risks of having a single monopoly and overcharge consumers, states regulate the PUCs retail sales, while FERC regulates the wholesale market [54], [63].

In the case of power wholesale, historically, the price is considered to be cost-based (not market-based). Therefore, the FERC adopted a cost-based regulatory approach to stimulate the exchange in the economy and protect buyers (small utilities) [55]. 


\subsubsection{Governance/Regulation of Wholesale Power Market}

Investor-owned utilities make decisions about long-term investments while considering the interest of all customers. These entities are regulated by state public service or utility commissions and administrated by a board of directors [64].

The power system regulation is linked to main legislative pieces: the 1978 Public Utility Regulatory Policy Act (PURPA), the 1992 Energy Policy Act (EPACT), the Electricity Modernization Act of 2005, and the Federal Energy Regulatory Commission Orders $888,889,2000$, and 2003-A. The PURPA mandates utilities to buy power from non-utility power producers. In this case, non-utilities generators could access the transmission networks. The EPACT required giving access to the transmission grid to generators or any utility on rates, and terms equivalent to transmission by itself. The EPAC was the basis for the formation of Independent System Operators (ISO). Later, more detailed norms of how to access the transmission grid and the operational systems were given by FERC by the orders 888 and 889 . Order 888 established the terms regarding how to charge the use of the transmission lines, and established that transmission and generation businesses be separated. Order 889 created an on-line system to post the available capacity by the transmission owners, and a list of companies that wanted to use the system. The Regional Transmission Organizations (RTOs) were encouraged (not required) be form after the order No 2000 "Transmission-own." The order 2003-A required the different levels of power generators to have access to the grid by establishing 20 megawatts for new generators to have access to the grid, and by defining who pays for the upgrading of the transmission line capacity [65], [56], [66], [47], [55], [46]. The Electricity Modernization 
Act of 2005 (EPACT 2005) enforced reliability standards to have reliable operations of the Bulk-Power System certified by the North American Electric Reliability Council (NERC) [67]. Currently, FERC regulates the pricing of wholesale transmission transactions, including utilities and industrial consumers [63].

The principal regulations and their functions are summarized in the following table:

Table 4: Electric Market System Regulators

Federal Regulatory Agencies

Federal Energy Regulatory Commission (FERC)

FERC regulates the rates and terms for most all the power transmission system, determining the structures of rates and who pays for upgrades. FERC does not regulate POU; however, FERC determines the economic value of transmission installations and benefits of these utilities [65].

\section{The North American Electric Reliability Corporation (NERC)}

NERC is a non-profit regulatory authority that was created by FERC to ensure the reliability of the bulk power, oversee, and regulate the electrical market based on reliability standards [51].

\section{State Regulatory Agencies}

\section{Public Utility Commission (PUC) / Public Service Commission / Commerce Commission}

The regulatory functions of States consider rates, some utility operations, and plan of utilities. These commissions oversee the costumers' requests and maintenance of distribution systems. Interstate utilities that are not under state regulators' jurisdictions are under the Interstate Commerce Commission (ICC) $[55],[51]$.

\section{State Department of Environmental Protection}

These organizations regulate the air, land, and water resources. The state is regulated by providing construction permits, ensuring public safety from contaminants and emissions [51].

Source: [65], [55], [51]

\subsection{Business Models - Structure Power Markets}

In general, organizations structure their strategies and operations based on principles and structures of business models. In the case of private organizations, these are the strategies and operations focused on obtaining profits, while in non-profit and 
government organizations, the objective is to satisfy the needs of customers [64]. The current U.S. electric market is based on a mix of IOUs, government-owned utilities (municipals states, and federal), and non-profit cooperatives [68]. In this section, below, it is followed the description given by Tarbert and Tuttle et al. [64] and [69], since the author clearly synthesized the main business models in the electric power industry.

\subsubsection{Investor-Owned Utilities (for Profit Ownership)}

Transmission and distribution organizations, as stated above, are considered natural monopolies, even in competitive market systems. The reason they are considered natural monopolies is based on the central dispatch requirements and the limitations to building infrastructures by more than one utility. Therefore, the grid of transmission has remained designated as a regulated natural monopoly after adopting deregulation systems. The Independent System Operators (ISOs) or the Regional Transmission Organizations (RTOs) manage the grid reliability by interacting with regulators and stakeholders [69].

In the United States, around $70 \%$ of the electric market is served by IOUs. Since these organizations are focused on obtaining profits, they pay dividends or share price appreciation. The business model and value proposition look for providing a return on investments to all the stakeholders. (see diagram below) [64].

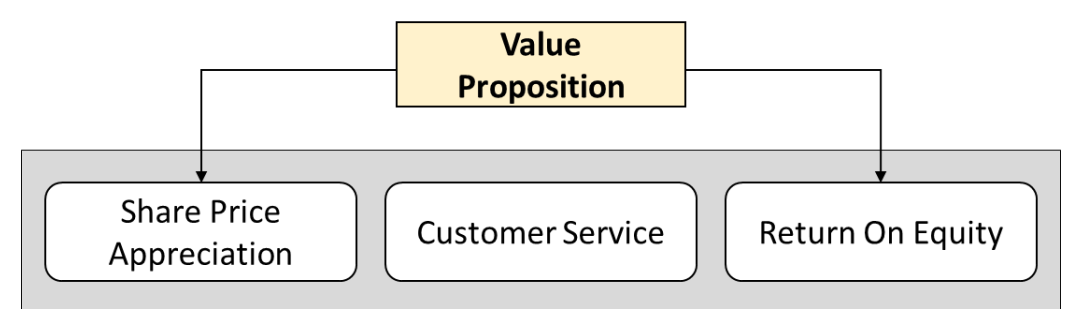

Figure 5: The IOU Business Model [64] 
These years, the vertically-integrated model still exists in some south, central, and northwestern U.S. areas. Twenty-three states and the District of Columbia have adopted some level of competition in the generation and retail levels [70].

There are four main structures of the electric utility considering the side of investor-owned utilities (IOUs) [69].

\section{Vertically Integrated (monopoly at all levels)}

Vertically integrated utilities belong to systems with no competition among the three activities (generation, transmission, and distribution); therefore, utilities are considered monopolies. A single monopoly utility can possess the generation, transmission, and distribution of electricity. Since there is no competition in the generation, consumers cannot choose the supplier. Commonly, states or consumers own electric companies around the world, and many traditional IOUs fit this model. Even the electric market tends to go in the direction of deregulation. There are some examples of currently existing natural monopoly structures, such as a municipally-owned utility [69].

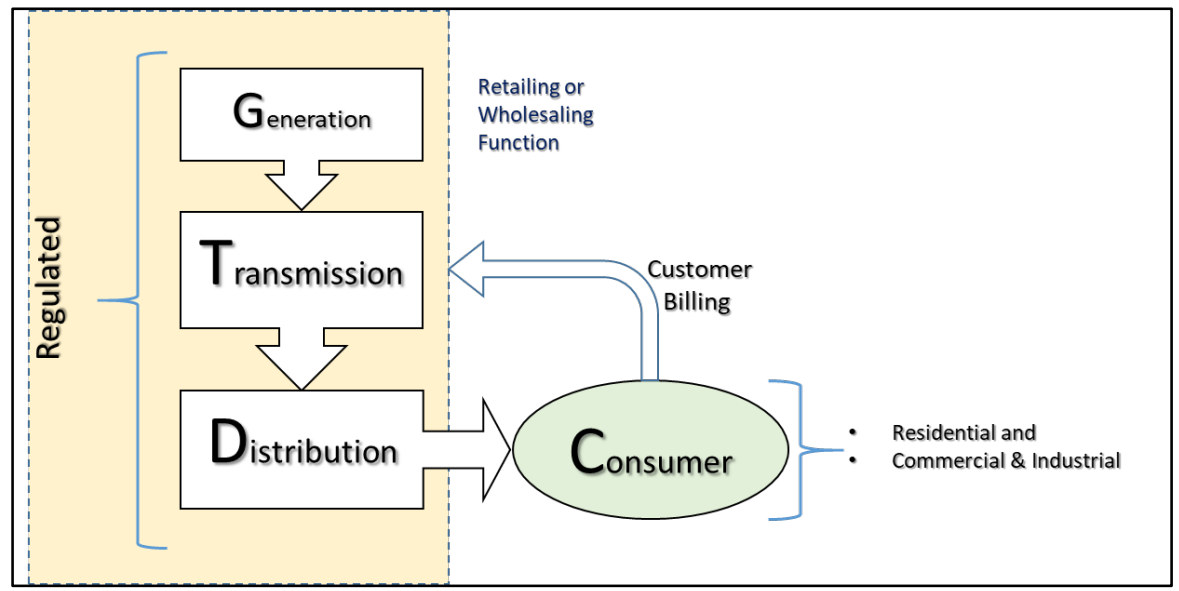

Figure 6: Traditional Vertically Integrated Utility Source: [69] 


\section{Single Buyer (limited competitive generation):}

The single-buyer model is based on facilitating wholesale competition. In this case, a single buyer who keeps the monopoly on transmission and customers can purchase from different generators. This model is associated with state-owned, vertically integrated utilities [69].

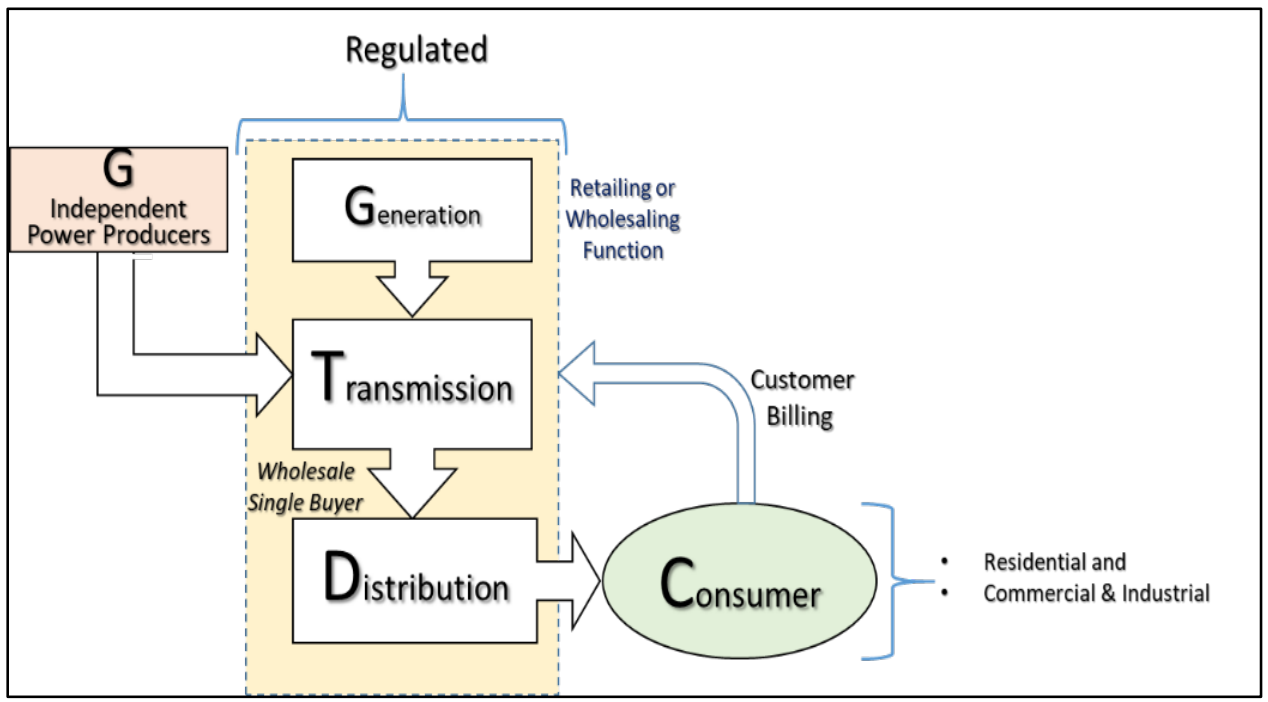

Figure 7: Traditional Vertically Integrated Utility with Wholesale Single Buyer Source: [69]

\section{Wholesale Competition of Generation}

In many cases, the wholesale competition model is preferable to the single buyer model. Instead of having a single buyer model, the wholesale model allows companies to own the distribution and retail networks and to buy wholesale electricity directly from competing producers on the transmission network, then delivering the electricity to customers (their access to transmission lines is granted). In this case, the dispatch in the generation and transmission is operated by a system operator, which is independent of other market participants [69]. 


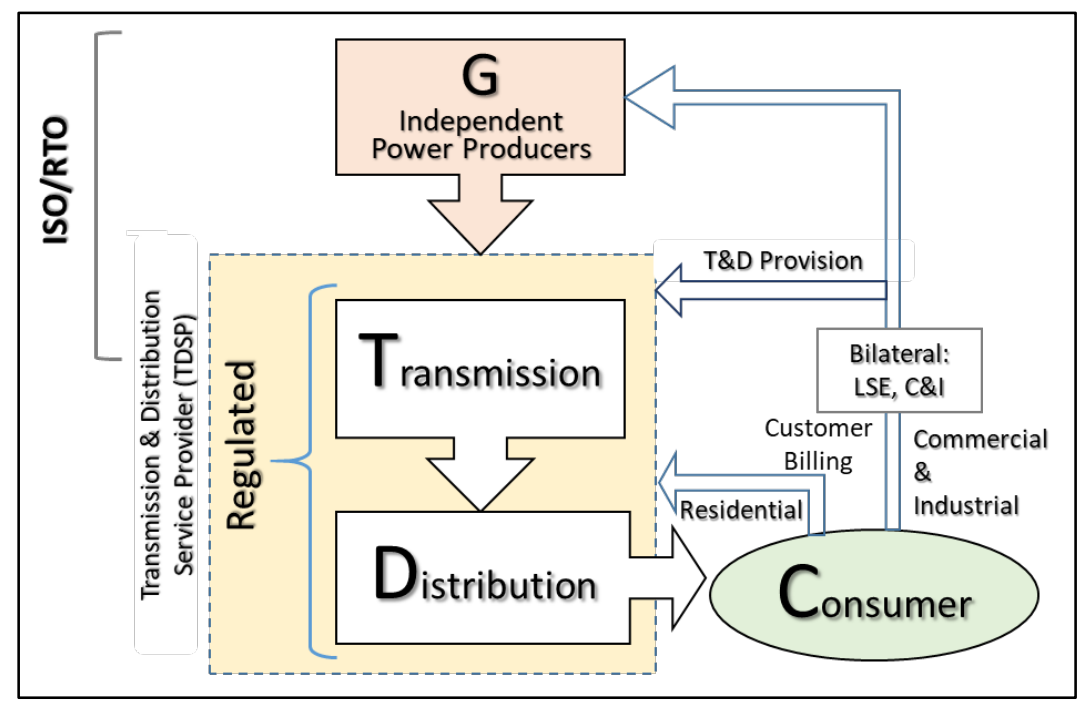

Figure 8: Wholesale Competition

Source: [69]

\section{Retail and Wholesale Competition}

Electricity consumers can choose their electricity suppliers, but to make it possible, transmission and distribution need to have open access. The transmission and distribution companies are regulated and correspond to the retail activities as "Transmission Service Providers (TSPs) and Distribution Service Providers (DSPs), or an integrated Wires and Poles" Transmission and Distribution Service Providers (TDSP).” Some U.S. states have systems that are close to this model, such as the retail choice program in the Electric Reliability Council of Texas (ERCOT) [69]. 


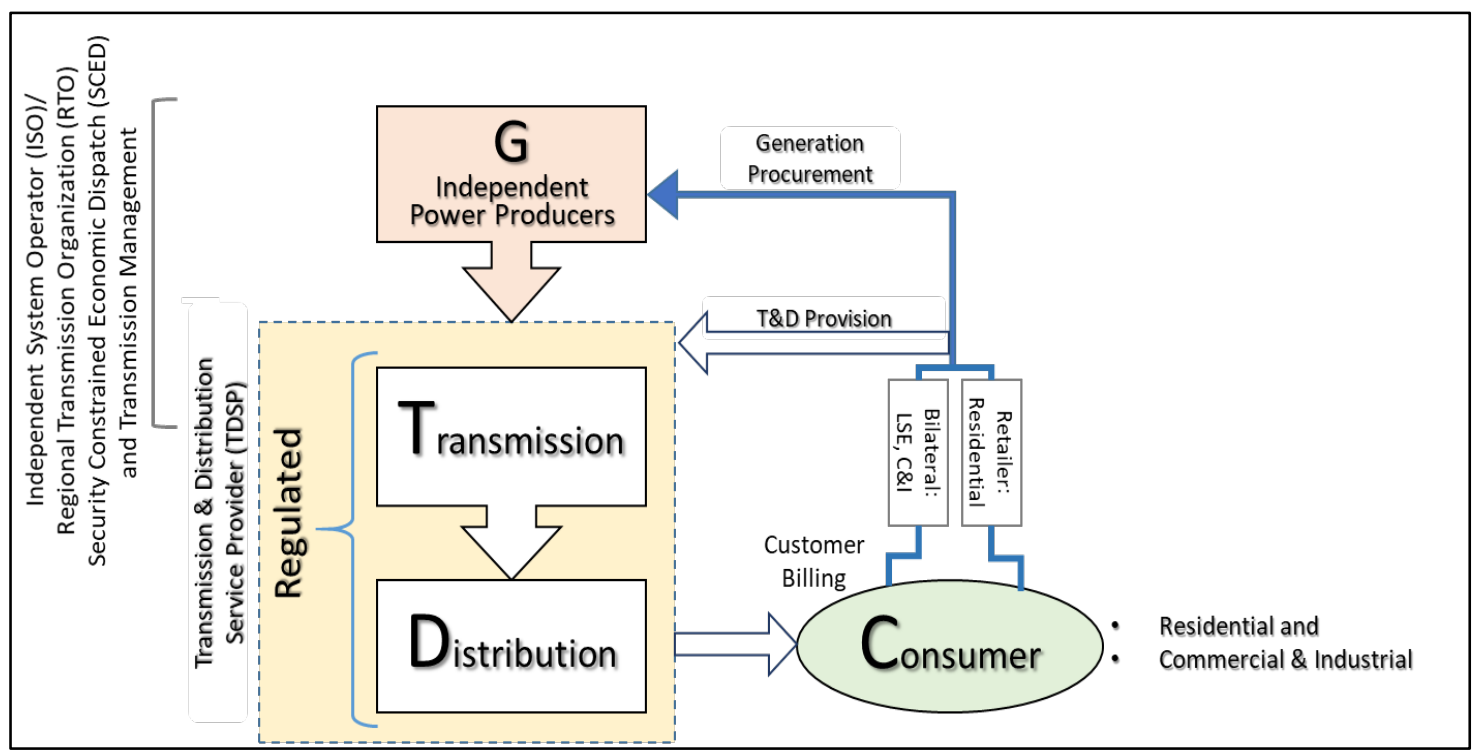

Figure 9: Wholesale \& Retail Competition

Source: [69]

\subsubsection{Non-profit Ownership Models}

The value proposition on these models is based on providing services to customers accomplishing lower rates and keeping a high quality of the product, such as good reliability and optimal customer service. If there is any extra revenue, it is integrated back to the system by returning lower rates in the future or increasing the investments to improve the quality of service; this also implies emergency funds are protected [64].

On a local level, these models can be described by five components: public ownership, local control, low-cost structure, non-profit operations, and customer-focused design- dedicated to the singular mission of delivering the highest level of service and value to customers/owners for the long term. 


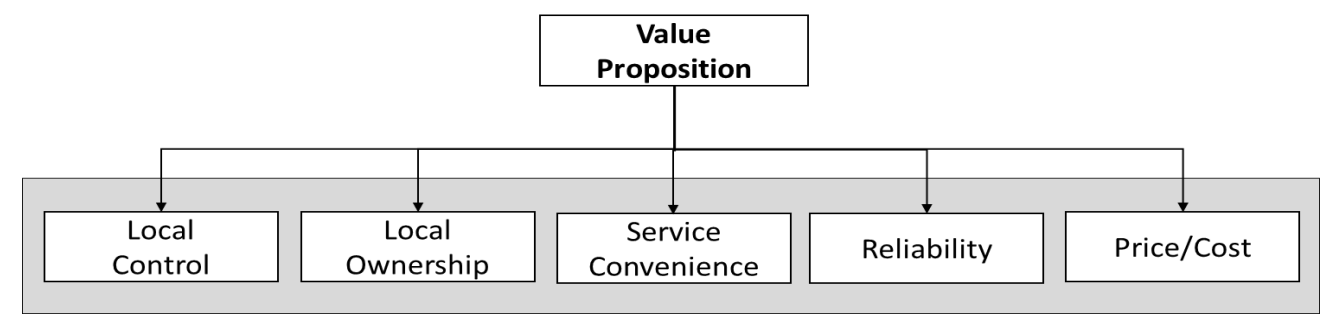

Figure 10: The Public Power Business Model [64]

In these models, grids are set up with a similar structure to for-profits models. With this design, there is a mix of for-profit and non-profit utilities, but they are integrated into the system.

\section{Vertically Integrated Municipally Owned Utilities}

The particularity of this model is that some cities own their electric utility, performing their activities in a similar setup as in the fully-integrated vertical model 1 . Therefore, residential, commercial, or industrial consumers are not able to elect their suppliers. The utility income and property taxes can be excluded or included in the cost of IOU-provided electricity service. [69].

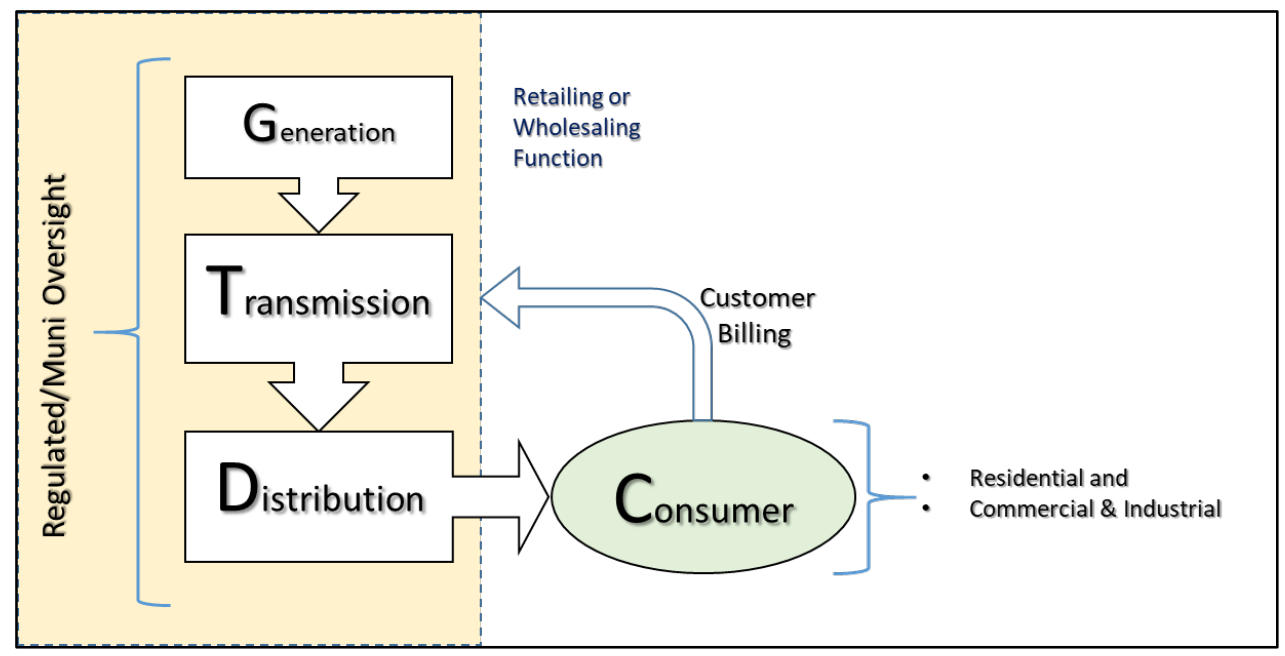

Figure 11: Traditional Vertically Integrated Municipal Utility Source: [69] 


\section{Administrations, Authorities, and Cooperatives (Co-Ops):}

Due to the lack of investments by investors or municipally-owned utilities, this model fit when utilities were located in low population density areas. Federal Power Marketing Administrations such as the Bonneville Power Administration can provide transmission and generation services.

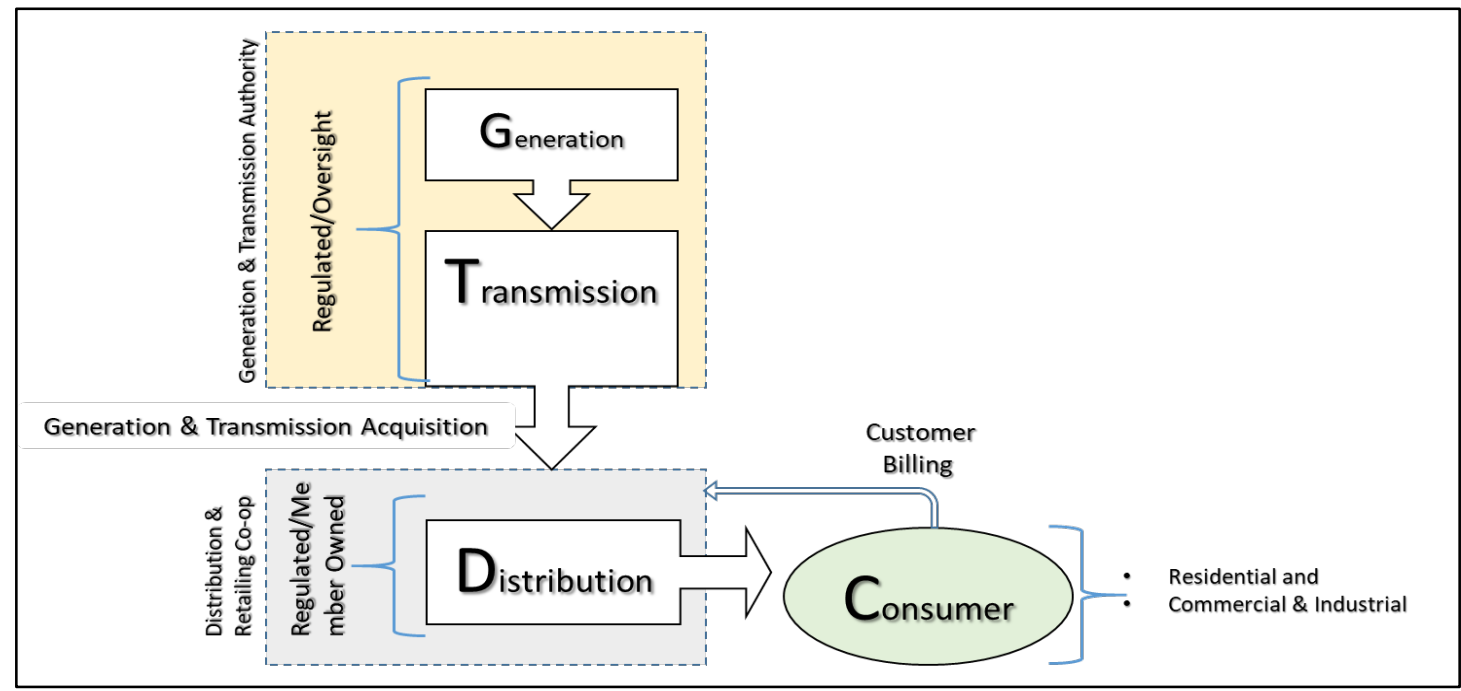

Figure 12: Generation \& Transmission + Distribution \& Retailer Source: [69]

\subsubsection{Electric Markets and Utilities' Ownership Structure}

As described above, there are different utility business models, which depend on the way of doing business (shareholders versus owners) and market situations (restructured versus vertically integrated and regulated). There are approximately 3,000 regulated private or public utilities in the different U.S. states. There are two types of utilities serving the system, the IOUs (investor-owned utilities) and POUs (consumer-owned utilities). The transmission of energy is served by RTOs and ISOs, using marginally lower cost methodologies. [71], [54]. 
Currently, transmission and distribution are considered natural monopolies on federal and state levels. Therefore, these two areas are regulated under the criteria of minimum costs that the market model can achieve [72]. Based on these five types of models and types of organizations, the structure of the electric market in the United States is summarized in the following table: 


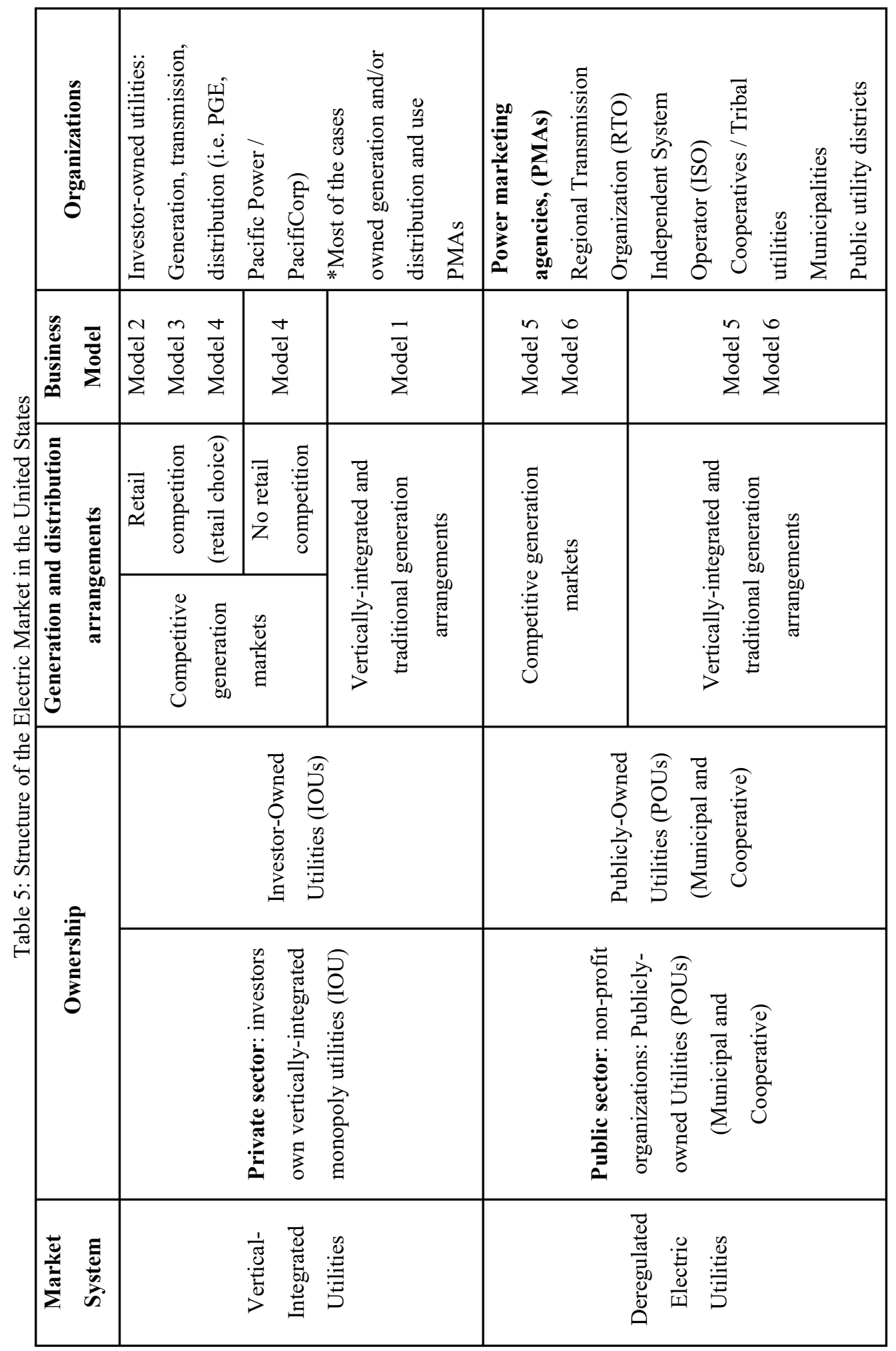


The number of electric utilities in 2017 is distributed as follow [73]:

Table 6: Number of electric utilities in 2017

\begin{tabular}{|l|c|}
\hline \multicolumn{1}{|c|}{ Type of Utility } & $\begin{array}{c}\text { Number of } \\
\text { Utilities }\end{array}$ \\
\hline Federal Utilities & 9 \\
\hline State Projects & 31 \\
\hline Public Power Districts & 133 \\
\hline Energy Service Providers & 143 \\
\hline Shareholder-Owned electric companies & 203 \\
\hline Cooperatives & 870 \\
\hline Non-utility Generators & 1688 \\
\hline Municipal Systems (Government-owned) & 1874 \\
\hline
\end{tabular}

Source: [73]

Notice that the Edison Electric Institute [73] considers the units of "non-utility generators"; therefore, the number of utilities is 3263. Additionally, "shareholder-owned electric companies" can be considered as investor-owned utilities, which are described above.

An important aspect to emphasize is that the two primary structures of the electric utilities are based on the type of ownership (IOUs or PUOs). Utilities, including cooperatives, municipals, public power districts, state projects, and federal utilities are owned by the governments, local communities, states, or by the private sector. This point will be described and explained later.

By narrowing the analysis and focusing on the electric transmission utilities considered as public non-profit utilities, Bonneville Power Administrations is taken as a reference point for the analysis. The context of how transmission utilities are organized and how organizations interact with each other can be seen directly in the type of customers 
of BPA. The organizations are described and categorized according to their characteristics and electric utility models.

\subsection{R\&D investment by Electric Utility Model}

The electric utility market has moved from regulated systems to deregulated systems. These changes are still in progress in the United States. The effects of changes, and the electric utility system itself, have created a complex order considering the type of organizations and stakeholders that interact in each state and among states and regions.

According to the different electric utility models and the organizations, the main patterns of R\&D investments can be differentiated in the following models and characteristics: private, non-profit, regulated, and deregulated models. Therefore, the analysis is focused on regulated models (IOUs and vertically integrated models) considering, at the same time, the type of ownership (private or publicly). As it was stated above, transmission utilities are still considered as natural monopolies and regulated by the federal and state governments; this reflects the importance of analyzing regulated utilities on evaluating R\&D projects.

As Daim et al. [74] stated, the levels of spending by electric utilities in research and development are low, especially during the last years. There is no consensus about the effects of business models or utility ownership on the levels of R\&D investment. The literature findings are diverse because of the changes in the electric utility industry and transitions of regulations and deregulations systems. It was explained above about the electric power market organization in the United States. The electric market and type of 
utility ownership in the United States are complex, and it has been influenced by regulatory, political (federal and state policies), and already natural monopoly conditions of the electric systems. In the area of transmission, it has been seen that high voltage power transmission utilities can be organized according to the ownership type and the area of influence of the utility, especially in the case of power marketing agencies (PMA), RTOs, and ISOs.

Therefore, the analysis of the effects of the type of utilities (focusing on the transmission sector) on the $R \& D$ investment is focused on the type of ownership and market conditions (including regulatory aspects).

It has been observed that the $R \& D$ investment fluctuations depend on the type of causes that change the electric market. Jamasb and Pollitt [75] made an in-depth analysis of how these effects from changing the organization's characteristics or market conditions can affect the R\&D investment. Below is presented a summary of these effects on the electric utilities:

Table 7: Electric Market Conditions and Effects on R\&D investments

\begin{tabular}{|c|c|c|}
\hline \multicolumn{2}{|c|}{ Characteristics / Changes } & \multirow{2}{*}{$\begin{array}{c}\text { R\&D Spending } \\
(-)\end{array}$} \\
\hline \multirow{2}{*}{ Restructuring aspects } & Reduced Firm Size & \\
\hline & Increased competition and uncertainty & $(+/-)$ \\
\hline \multirow{3}{*}{ Ownership aspects } & Increased privatization and private ownership & $(+/-)$ \\
\hline & Increased mergers and acquisitions & $(-)$ \\
\hline & Increased leverage, investment, dividends, etc. & $(+/-)$ \\
\hline \multirow{2}{*}{ regulatory aspects } & Regulation as a policy tool & $(+)$ \\
\hline & Incentive regulation & $(-)$ \\
\hline
\end{tabular}

Source: Adapted from [75] (information extracted focusing on electric utilities).

$(-),(+),(+/-)$ are the negative, positive, or mixed results, respectively. 
Overall, the effects of different utility ownership conditions on R\&D investments are mixed. There is a tendency of negative consequences from restructuring actions that influence the ownership and regulatory conditions [76]. Therefore, it can be inferred that variations on the $\mathrm{R} \& \mathrm{D}$ investment levels are according to the time of restructuring the markets. The electric power market deregulations policies during the 1990s coincided with reductions in R\&D investments. The negative effects of restructuring policies persisted in the long run [75]. The negatives effects of type of ownership (private or publicly owned) on the R\&D investment levels have been corroborated by Schmitt and Denes [76]. These authors [76] explains that the introduction of competition tends to influence negatively in the beginning, but once the market and the regulatory policies are clear and steady, the levels of R\&D investment start increasing. Therefore, from the table above and the appreciations of different authors, it can be inferred that public or private ownership reacts negatively to changes in rules and market conditions in the short run.

Public ownership gives the authority to the government to influence the electric utilities while at the same time directly affecting the decision of R\&D investments [76]. However, as it is shown in the work of Jamasb and Pollitt, and Schmitt and Denes [75] and [76], the variations of publicly-owned utilities do not have a clear pattern; it is slightly negative, but fluctuations have changed year by year.

The utilities' objectives of private utilities, many of which were formed after deregulation policies, were affected by the process of privatizations, explained by the related incentives and behaviors. It was found that regulation negatively affected R\&D 
investments, but once the market adjusted to the new circumstances (after regulations), the private companies tended to increase their R\&D investments [76].

The effects of vertically integrated utilities on the $R \& D$ investments are linked to the ownership and regulation conditions. However, the levels of this type of investment are associated with the transitional period from vertically integrated systems to separated activities of ownership and more competitive markets. It was found that there are low levels of $R \& D$ investments in systems in short transitions periods; however, these effects are associated with the size of the organization [76].

\subsection{Factors Influencing R\&D Project Selection}

The R\&D process involves multiple interrelated criteria, resources, and factors that are not easily measured and evaluated, implying a challenge for decision-makers for investing in R\&D projects [3]. Chen and Hung [35] indicate that these factors include new technologies, shorter technologies cycles, globalization, changes in the market, and demand. Moreover, due to the complexity of selecting R\&D projects and the number of factors influencing them, there are risks and uncertainties associated with investments and the returns of these types of projects [5]. Therefore, the R\&D project selection can be viewed as a multiple criteria decision-making problem [30]. Table 8 and Table 9 show the criteria and sub-criteria considered in the literature. These aspects are highly linked to $R \& D$ project selection. 
Table 8: R\&D Project Selection - Criteria

\begin{tabular}{|c|c|c|c|c|c|}
\hline \multicolumn{6}{|c|}{ References } \\
\hline [77] & {$[78]$} & & [5] & & 79] \\
\hline Criteria & Criteria & $\begin{array}{c}\text { Phases of the } \\
\text { project }\end{array}$ & Criteria & $\begin{array}{c}\text { Phases of the } \\
\text { project }\end{array}$ & Criteria \\
\hline $\begin{array}{l}\text { Market } \\
\text { Competitiveness } \\
\text { Technical } \\
\text { factors } \\
\text { Capability } \\
\text { Environmental } \\
\text { Factor }\end{array}$ & $\begin{array}{l}\text { Economic } \\
\text { Impact } \\
\text { Commercial } \\
\text { potential } \\
\text { Inner } \\
\text { capacity } \\
\text { Technical } \\
\text { spin-off. }\end{array}$ & $\begin{array}{l}\text { - Basic } \\
\text { Research } \\
\text { - Applied } \\
\text { Research } \\
\text { - Development. }\end{array}$ & $\begin{array}{l}\text { - Innovation } \\
\text { - Technological } \\
\text { - Project } \\
\text { Attributes } \\
\text { - Organizational } \\
\text { - Market } \\
\text { - Environmental. } \\
\text { - Risk }\end{array}$ & $\begin{array}{l}\text { - } \text { Basic } \\
\text { Research } \\
\text { - Applied } \\
\text { Research } \\
\text { - Development. }\end{array}$ & $\begin{array}{l}\text { - } \text { Technical } \\
\text { - } \text { Market } \\
\text { - }\end{array}$ \\
\hline
\end{tabular}

\begin{tabular}{|c|c|c|c|c|}
\hline \multicolumn{5}{|c|}{ References } \\
\hline$[35]$ & [80] & [81] & & [82] \\
\hline Criteria & Criteria & Criteria & Aspects & Objectives \\
\hline $\begin{array}{l}\text { - Company's } \\
\text { technical ability } \\
\text { and } \\
\text { patentability } \\
\text { resource } \\
\text { - Potential } \\
\text { customer and } \\
\text { stability of the } \\
\text { market } \\
\text { - Company's } \\
\text { financial ability }\end{array}$ & $\begin{array}{l}\text { - Energy- } \\
\text { environmental } \\
\text { - Economical } \\
\text { spin-off } \\
\text { - Technical Spin- } \\
\text { off } \\
\text { - Marketability } \\
\text { - KIER mission }\end{array}$ & $\begin{array}{l}\text { - Manufacturing } \\
\text { - Technical } \\
\text { - Marketing/ } \\
\text { Distribution. } \\
\text { - FROV }\end{array}$ & $\begin{array}{l}\text { - Benefits } \\
\text { - Technology } \\
\text { - Execution }\end{array}$ & $\begin{array}{l}\text { - Economic benefits } \\
\text { - Social benefits } \\
\text { - Competitiveness } \\
\text { - Relevance } \\
\text { - Feasibility } \\
\text { - Success rate }\end{array}$ \\
\hline
\end{tabular}

Table 9 shows the different criteria that have been used in the literature. There are different criteria in each study addressing the objective of R\&D project selection depending on the used method and the specific type of organization or application of the study. The criteria selection depends on the objectives of the organization. The importance of selecting the adequate criteria is emphasized by Hudymáčová et al. [83] since the adequacy of the criteria allows achieving the objectives. 
For selecting $R \& D$ projects, one of the main criteria is the market. The Market criterion is extensively used especially for products that will be commercialized in the future. The Market criterion is also used to measure the size of the application of new technology. Technology is another criterion that is used to measure the compatibility of the technology with technical aspects of the systems and the capability to develop them. Organizational factors are also considered for the strategic objective and the alignment of the technology with specific and general objectives of organizations. Organizational aspects also allow for measuring the staff competence of the organization. The Economic criterion is an aspect that focuses more on financial capabilities. Some authors consider the economic aspect together with the market aspect; however, due to the measure of the economic benefits by applying specific ratios or evaluation tools, the market is frequently treated separately to measure the external market or specific aspects of the market characteristics. Finally, external factors are characterized by the Environmental criteria that are associated with forces that affect the $R \& D$ projects out of the decisions of the organizations. In some studies, the criteria are evaluated by the phase that the projects are facing [5], [79]. However, these criteria are used for Analytical Network Process (ANP). 
Table 9: (Tables A, B, ... L) - R\&D Project Selection - Sub-criteria

\begin{tabular}{|l|l|}
\hline \multicolumn{1}{|c|}{ Criteria } & \multicolumn{1}{c|}{ Sub-criteria } \\
\hline \multirow{3}{*}{ Market } & - Span of applications opened by technology \\
& - Potential for commercialization \\
& - Supporting national related strategies \\
\hline \multirow{3}{*}{ Competitiveness } & - Key of technology \\
& - Competitive situation in market \\
& - Added value \\
\hline \multirow{3}{*}{ Technical factors } & - Position of the technology in its own life-cycle \\
& - Threat of substitution technologies \\
& - Ability to result in technical Know-How \\
\hline \multirow{3}{*}{ Capability } & - Ability to use international cooperation \\
& potentials \\
\hline Environmental Factors & - Alignment with organization \\
& - objective and capability \\
& - Value of laboratories \\
\hline
\end{tabular}

(B)

[78]

\section{Criteria}

- Economic Impact

- Commercial potential

- Inner capacity

- Technical spin-off

(C)

\begin{tabular}{|c|c|c|}
\hline \multicolumn{3}{|r|}{ [5] } \\
\hline Phases of project & Criteria & Sub-criteria \\
\hline \multirow{4}{*}{$\begin{array}{l}\text { Basic Research } \\
\text { Applied Research } \\
\text { Development }\end{array}$} & Innovation & $\begin{array}{l}\text { - Incremental Innovation } \\
\text { - Radical Innovation }\end{array}$ \\
\hline & Technological & $\begin{array}{l}\text { - High Technology } \\
\text { - Low Technology }\end{array}$ \\
\hline & Project Attributes & $\begin{array}{l}\text { - Potential Market Interaction with the previous product } \\
\text { - Potential technical interaction with existing product } \\
\text { - Strategic need } \\
\text { - Expected benefit } \\
\text { - Product life }\end{array}$ \\
\hline & Organizational & $\begin{array}{l}\text { - Competence and experience on similar projects } \\
\text { - Raw material/component availability } \\
\text { - Knowledge/skill availability }\end{array}$ \\
\hline
\end{tabular}




\begin{tabular}{|c|c|c|}
\hline \multicolumn{3}{|r|}{ [5] } \\
\hline Phases of project & Criteria & Sub-criteria \\
\hline & & $\begin{array}{l}\text { - Research staff availability } \\
\text { - Facilities available }\end{array}$ \\
\hline & Market & $\begin{array}{l}\text { - Competitors effort in similar areas } \\
\text { - Relationship with user } \\
\text { - Expected market share } \\
\text { - Potential market size }\end{array}$ \\
\hline & Environmental & $\begin{array}{l}\text { - Economic regulations } \\
\text { - Environmental policy } \\
\text { - Safety considerations } \\
\text { - Government policy } \\
\text { - Social atmosphere }\end{array}$ \\
\hline & Risk & $\begin{array}{l}\text { - Technical risk } \\
\text { - Commercial risk } \\
\text { - Economic risk }\end{array}$ \\
\hline
\end{tabular}

(D)

\begin{tabular}{|c|c|c|}
\hline \multicolumn{3}{|r|}{ [79] } \\
\hline Phases of project & Criteria & Sub-criteria \\
\hline \multirow{3}{*}{$\begin{array}{l}\text { Basic Research } \\
\text { Applied Research } \\
\text { Development }\end{array}$} & Technical & $\begin{array}{l}\text { - Probability of technical success } \\
\text { - Existence of project champion } \\
\text { - Existence of required competence } \\
\text { - Availability of available resources } \\
\text { - Applicability to other products and processes } \\
\text { - Time to market }\end{array}$ \\
\hline & Market & $\begin{array}{l}\text { - Probability of market success of product } \\
\text { - Potential size of market } \\
\text { - Product life cycle } \\
\text { - Number and strength of competitors } \\
\text { - Net present value (NPV). }\end{array}$ \\
\hline & Organizational & $\begin{array}{l}\text { - Strategic fit } \\
\text { - External regulations } \\
\text { - Workplace safety } \\
\text { - Environmental considerations }\end{array}$ \\
\hline
\end{tabular}


(E)

[80]

\begin{tabular}{|c|l|}
\hline \multicolumn{1}{|c|}{ Criteria } & \multicolumn{1}{c|}{ Sub-criteria } \\
\hline \multirow{2}{*}{ Energy environmental } & - High oil prices \\
& - UNFCCC \\
& - Hydrogen economy \\
\hline \multirow{2}{*}{ Economical spin-off } & - Energy savings \\
& - CO2 reduction \\
\hline \multirow{2}{*}{ Technical spin-off } & - Technology development urgency \\
& - Technology level/Target level \\
& - Possibility of commercialization \\
\hline Marketability & - Domestic/foreign market size \\
& - Market size for exportation \\
& - Job creation effects \\
\hline & - National policy connection \\
& - Public sector \\
& - Internal capacity \\
\hline
\end{tabular}

(F)

\section{Criteria}

- Company's technical ability and patentability resource

- Potential customer and stability of the market

- Company's financial ability

(G)

\begin{tabular}{|c|c|}
\hline \multicolumn{2}{|r|}{ [81] } \\
\hline Criteria & Sub-criteria \\
\hline Manufacturing & $\begin{array}{l}\text { - Capability } \\
\text { - Facilities / Equipment } \\
\text { - Workplace safety } \\
\text { - Environmental Considerations }\end{array}$ \\
\hline Technical & $\begin{array}{l}\text { - Success Probability } \\
\text { - Contribution } \\
\text { - Time } \\
\text { - Resources }\end{array}$ \\
\hline Marketing / Distribution & $\begin{array}{l}\text { - Potential } \\
\text { - Capability } \\
\text { - Trends }\end{array}$ \\
\hline FROV & \\
\hline
\end{tabular}

(H)

[82] 


\begin{tabular}{|c|c|c|}
\hline Aspects & Objectives & Criteria \\
\hline \multirow[t]{2}{*}{ Benefits } & Economic benefits & $\begin{array}{l}\text { - Market scope of application } \\
\text { - Growth potential of product } \\
\text { - Value-added of target products } \\
\text { - Relatedness of industry }\end{array}$ \\
\hline & Social benefits & $\begin{array}{l}\text { - Improvements on QESIS } \\
\text { - Concatenation with S\&T policy } \\
\text { - Benefits for human life }\end{array}$ \\
\hline \multirow{2}{*}{ Technology } & Competitiveness & $\begin{array}{l}\text { - Innovativeness } \\
\text { - Advancement of technology } \\
\text { - Proprietary technology }\end{array}$ \\
\hline & Relevance & $\begin{array}{l}\text { - Generics or specific } \\
\text { - Technological connections } \\
\text { - Extendibility }\end{array}$ \\
\hline \multirow[b]{2}{*}{ Execution } & Feasibility & $\begin{array}{l}\text { - Soundness of scientific principles } \\
\text { - Quality of proposal } \\
\text { - Capability of research team } \\
\text { - Safety and pollution concerns }\end{array}$ \\
\hline & Success rate & $\begin{array}{l}\text { - Intensity of competition } \\
\text { - Favorable environments } \\
\text { - Availability of complementary } \\
\text { - Assets } \\
\text { - Timing }\end{array}$ \\
\hline
\end{tabular}

(I)

[12]

- Impact on enhancing Firm Productivity

- Profitability

- Quality Improvement

- Appropriateness

- For research project timing

- Synergy with other projects

- Impact on enhancing Innovation

- Advancement of related Technology

- Extensibility of results and Span of application 
(J)

\section{[10]}

\begin{tabular}{|c|c|}
\hline \multicolumn{2}{|r|}{ [10] } \\
\hline Criteria & Sub-criteria \\
\hline Technological merit & $\begin{array}{l}\text { - Competitiveness of technology Social ambiance } \\
\text { - Potential technical interaction with existing technology }\end{array}$ \\
\hline Technical & $\begin{array}{l}\text { - Technical resource availability Anticipated Completion time } \\
\text { - Attractiveness of technological route } \\
\text { - Probability of technical success }\end{array}$ \\
\hline Risk & $\begin{array}{l}\text { - Technical risk } \\
\text { - Commercial risk } \\
\text { - Economic risk } \\
\text { - Development risk } \\
\text { - Risk in obtaining regulatory clearance } \\
\end{array}$ \\
\hline Market & $\begin{array}{l}\text { - The potential size of market Expected market share Financial feasibility } \\
\text { - Number and strength of competitor }\end{array}$ \\
\hline Regulation & $\begin{array}{l}\text { - Government policy } \\
\text { - Economic regulation } \\
\text { - Environmental policy } \\
\text { - Ability to meet likely future regulation } \\
\end{array}$ \\
\hline
\end{tabular}

(K)

\begin{tabular}{|c|c|}
\hline \multicolumn{2}{|r|}{ [77] } \\
\hline Criteria & Sub-criteria \\
\hline Project attributes & $\begin{array}{l}\text { - Expected utility } \\
\text { - Strategic need } \\
\text { - Product life } \\
\text { - Potential technical interaction with existing products } \\
\text { - Potential market } \\
\text { - interactions with the previous product }\end{array}$ \\
\hline Organizational attributes & $\begin{array}{l}\text { - Competence and experience on similar project } \\
\text { - Knowledge/ skills availability } \\
\text { - Research staff availability } \\
\text { - Raw material/ component available } \\
\text { - Facilities available }\end{array}$ \\
\hline Market attributes & $\begin{array}{l}\text { - Potential market size } \\
\text { - Expected market share } \\
\text { - Degree of competence } \\
\text { - Competitors effort in similar areas }\end{array}$ \\
\hline Environmental attributes & $\begin{array}{l}\text { - Government policy } \\
\text { - Economic regulations } \\
\text { - Social ambience } \\
\text { - Safety considerations } \\
\text { - Environmental policy } \\
\end{array}$ \\
\hline Risk & $\begin{array}{l}\text { - Technical risk } \\
\text { - Commercial risk } \\
\text { - Economic risk }\end{array}$ \\
\hline Category & $\begin{array}{l}\text { - Fundamental research } \\
\text { - Advanced research } \\
\text { - Engineering research } \\
\text { - Management and support related research }\end{array}$ \\
\hline
\end{tabular}

(L) 


\begin{tabular}{|c|c|}
\hline \multicolumn{2}{|r|}{ [84] } \\
\hline Criteria & Sub-criteria \\
\hline Benefits & $\begin{array}{l}\text { - Benefits to public knowledge base } \\
\text { - Benefits to market } \\
\text { - Benefits to network innovation } \\
\text { - Quality }\end{array}$ \\
\hline Risks & $\begin{array}{l}\text { - Quality of project } \\
\text { - Capabilities of firm and partners Quality of research team }\end{array}$ \\
\hline Costs & $\begin{array}{l}\text { - Estimated costs } \\
\text { - Project efficiency } \\
\text { - Funding efficiency }\end{array}$ \\
\hline
\end{tabular}

As it is observed in Table 9, the sub-criteria for each criterion have similarities, which vary in some cases by their purposes within the general objective of the evaluation.

\subsection{R\&D Project Selection Methods}

The evolution of project selection has corresponded to changing needs. The first methods focused on financial analysis and the assessment of the projects was based on financial data [40]. At the same time, early selection models were made based on linear programming, scoring models, and checklists. These methods monetize the attributes [12].

Ashrafi et al., Changsheng Yi, Hashemkhani Zolfani et al., and Changsheng Yi [12], [19], [10], [19] identified three classes of approaches: quantitative methods, qualitative methods, and hybrid methods. Many techniques and methods are used for portfolio selection [85].

R\&D project selection can be viewed as a multiple criteria decision-making problem [30]. There are many criteria and sub-criteria considered in the literature affecting the decision of selecting R\&D projects. As Guo et al. [85] explain, there are relatively many techniques and approaches that are used for project portfolio selection. Ashrafi et al., 
Changsheng Yi, Hashemkhani Zolfani et al., and Changsheng Yi [12], [19], [10], [19] categorized three classes of approaches: quantitative methods, qualitative methods, and hybrid methods. These methods are summarized in the following table.

Table 10: R\&D Project Selection Methods

\begin{tabular}{|c|c|c|c|c|}
\hline $\begin{array}{l}\text { Mathematical } \\
\text { programming } \\
\text { and portfolio } \\
\text { optimization }\end{array}$ & Decision Analysis & $\begin{array}{l}\text { Economic } \\
\text { Models = } \\
\text { Financial } \\
\text { Methods }\end{array}$ & $\begin{array}{l}\text { Interactive Method = } \\
\text { Judgmental Methods } \\
=\text { consensus models }\end{array}$ & $\begin{array}{l}\text { Hybrid } \\
\text { methods }\end{array}$ \\
\hline $\begin{array}{c}{[86],[35],[27],} \\
{[87],[12],[3]}\end{array}$ & {$[86],[35],[3]$} & $\begin{array}{c}{[86],[35],[27],} \\
{[12],[3]}\end{array}$ & {$[86],[35],[27],[3]$} & {$[12]$} \\
\hline $\begin{array}{l}\text { - Integer } \\
\text { Programming } \\
\text { (I.P.) } \\
\text { - Linear } \\
\text { Programming } \\
\text { (L.P.) } \\
\text { - Non-linear } \\
\text { Programming } \\
\text { (NLP) } \\
\text { - Goal } \\
\text { programming } \\
\text { (G.P.) } \\
\text { - Dynamic } \\
\text { Programming } \\
\text { (DLP) } \\
\text { - Portfolio } \\
\text { Optimization }\end{array}$ & $\begin{array}{l}\text { - Multi-attribute } \\
\text { Utility Theory } \\
\text { (MAUT) } \\
\text { - Decision Trees, } \\
\text { Risk Analysis } \\
\text { - Analytic } \\
\text { Hierarchy } \\
\text { Process (AHP) } \\
\text { - Hierarchical } \\
\text { Decision Model } \\
\text { (HDM) }\end{array}$ & $\begin{array}{l}\text { - Internal Rate } \\
\text { Return (IRR) } \\
\text { - Net Present } \\
\text { Value (NPV) } \\
\text { - Return on } \\
\text { Investment } \\
\text { (ROI) } \\
\text { - Cost-Benefit } \\
\text { Analysis } \\
\text { - Option Pricing } \\
\text { Theory } \\
\text { - Merit-cost } \\
\text { Value Index }\end{array}$ & $\begin{array}{l}\text { - Q-Sort, behavioral } \\
\text { decision aids (BDA) } \\
\text { - Decentralized } \\
\text { Hierarchical } \\
\text { Modeling (DHM) } \\
\text { - Decision Support } \\
\text { Systems (DSS) } \\
\text { - AHP } \\
\text { - HDM } \\
\text { - Spreadsheet Model } \\
\text { for Rating Projects } \\
\text { - Cost-Benefit } \\
\text { Analysis with ILP } \\
\text { for resource } \\
\text { allocation }\end{array}$ & $\begin{array}{l}\text { - Mix of two } \\
\text { or more } \\
\text { methods }\end{array}$ \\
\hline
\end{tabular}

The analysis of the strengths and weaknesses of other methods are summarized below: 


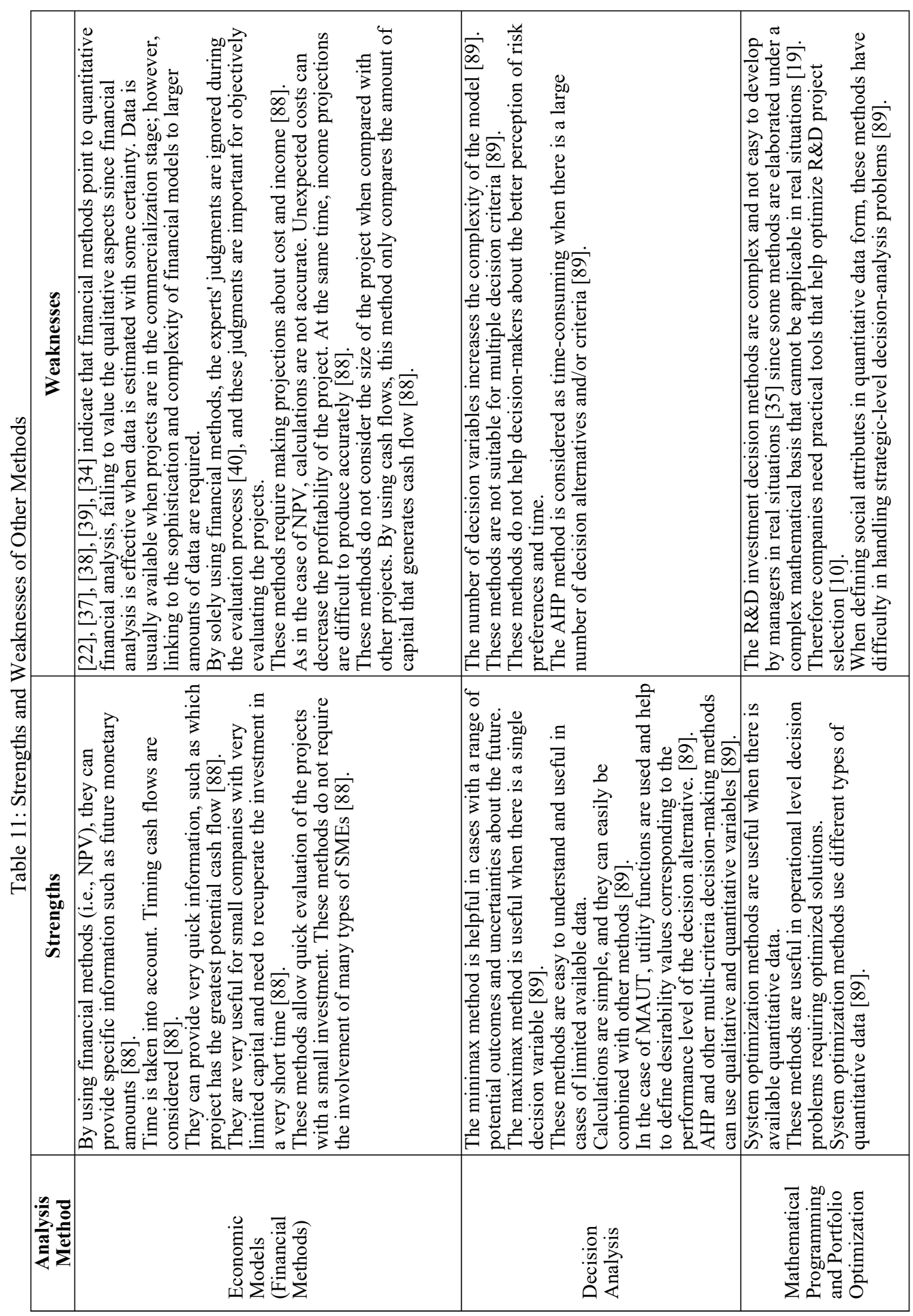




\section{CHAPTER 3: RESEARCH GAPS and GOALS}

\subsection{Literature Review and Gaps}

There are many studies analyzing R\&D investment and portfolio selection using diverse methodologies; however, most of them are focused on organizations with profit objectives. Few studies are focusing on non-profit or regulated organizations. Moreover, some of the studies analyze R\&D project selection by public or government organizations; however, there are no studies about regulated non-profit electric utilities. In the area of public, government, and regulated sectors, there are few studies focused on R\&D project selection [90].

The studies about R\&D portfolio selection are concentrated mostly on analyzing private companies and not on public or government organizations. Furthermore, few studies are focusing on non-profit, regulated, and electric utilities, especially in the transmission sector [27]. There are many models and methods to evaluate R\&D projects; however, very little of the research is done on projects sponsored by governments. Moreover, there is no research about regulated transmission utilities.

R\&D project selection in a portfolio context has received insufficient attention, as most of the studies are focused on individual project analysis [29]. A majority of organizations use standard methods based on monetary aspects, failing to include in their R\&D project selection the type of organizations, multiple perspectives, and strategy aspects [30]. Below is presented an analysis of studies and methods that are related to the identified problems. 
Table 12: Identification of Gaps

\begin{tabular}{|c|c|c|c|}
\hline Topic & $\begin{array}{c}\text { Studies } \\
\text { Considering the } \\
\text { topic }\end{array}$ & Used Methods & Gaps \\
\hline $\begin{array}{l}\text { Multi-factor } \\
\text { Analysis / } \\
\text { Qualitative } \\
\text { Factors }\end{array}$ & $\begin{array}{l}\text { [12], [10], [27], [6], } \\
{[91],[92],[81]}\end{array}$ & $\begin{array}{l}\text { - Mathematic programming } \\
\text { - Decision Support System } \\
\text { DDS } \\
\text { - Weight Assessment Ratio } \\
\text { Analysis SWARA } \\
\text { - Fuzzy analytic hierarchy } \\
\text { process } \\
\text { - Analytic Hierarchy Process } \\
\text { - Fuzzy ANP } \\
\text { - Real options valuation } \\
\text { - Fuzzy multi-criteria } \\
\text { - Fuzzy TOPSIS }\end{array}$ & $\begin{array}{l}\text { The evaluation methods tend } \\
\text { to focus on individual } \\
\text { factors. Few studies consider } \\
\text { the multi-criteria analysis } \\
\text { and incorporate interested } \\
\text { stakeholders' perspectives. } \\
\text { The R\&D investment } \\
\text { decision methods are } \\
\text { complex and not easy to } \\
\text { develop by managers in real } \\
\text { situations. }\end{array}$ \\
\hline $\begin{array}{l}\text { Long Run } \\
\text { Strategy } \\
\text { Analysis }\end{array}$ & $\begin{array}{l}{[93],[27],[26],} \\
{[86]}\end{array}$ & $\begin{array}{l}\text { - Optimal sequencing } \\
\text { - Fuzzy analytic hierarchy } \\
\text { process } \\
\text { - Optimal analysis } \\
\text { - mathematical models with } \\
\text { knowledge rules }\end{array}$ & $\begin{array}{l}\text { Few studies consider the } \\
\text { organization's long-run } \\
\text { competitiveness. }\end{array}$ \\
\hline $\begin{array}{l}\text { Organization } \\
\text { Strategy }\end{array}$ & [91] & - Fuzzy ANP & $\begin{array}{l}\text { There is a lack of studies } \\
\text { about organization } \\
\text { strategies, the stakeholders' } \\
\text { perspectives, and the } \\
\text { qualitative benefits. }\end{array}$ \\
\hline $\begin{array}{l}\text { Economic } \\
\text { Analysis }\end{array}$ & $\begin{array}{l}{[13],[19],[93],} \\
{[94],[85],[11],} \\
{[22],[23],[26],} \\
{[14],[30],[6],[95],} \\
{[90],[8],[96],[87]}\end{array}$ & $\begin{array}{l}\text { - Real options } \\
\text { - Net present value (NPV) } \\
\text { - Linear programming } \\
\text { - Optimal sequencing } \\
\text { - Mathematical Programing } \\
\text { - Decision Theory Model and } \\
\text { scoring model. } \\
\text { - Nonlinear mathematic } \\
\text { programming } \\
\text { - Fuzzy - Real options } \\
\text { - Integer programming } \\
\text { - Quantum genetic algorithm } \\
\text { - Optimal analysis } \\
\text { - Cost/Benefit analysis } \\
\text { - Analytic Hierarchy Process } \\
\text { - AHP) } \\
\text { - Data Envelopment Analysis } \\
\text { (DEA) } \\
\text { - Nonlinear discontinuous bi- } \\
\text { criterion optimization } \\
\text { - Fuzzy zero-one integer } \\
\text { programming model }\end{array}$ & $\begin{array}{l}\text { The evaluation methods } \\
\text { focus on monetarizing the } \\
\text { analysis is complex and do } \\
\text { not fully consider qualitative } \\
\text { factors. }\end{array}$ \\
\hline
\end{tabular}


Many authors have considered a multi-criteria analysis of R\&D projects. In general, the studies focus on specific criteria and are more oriented to methodological aspects. The studies focus on linear programming and multi-criteria analysis, as is showed in Table 4. For example, Ashrafi et al., and Oral et al. [12] and [92] use mathematical programming methods addressing project selection with interdependencies. Ashrafi et al. [12] consider a portfolio selection under risk and project interdependency. Even by focusing on portfolio selection, few aspects or criteria are taken into account. The method that is used is based on algorithms and seems too complicated and not holistic. Oral et al. [92] use only expected contributions in many aspects such as technical, economic, scientific, and social contributions; however, the analysis is complex, and the criteria are too general.

The Analytical Hierarchical Process (AHP) is used by Liberatore [6]; however, the analysis is limited by the use of a certain number of criteria and factors, mainly focusing on cost aspects. The project's selection is weighted individually and not as a portfolio in a simplistic model and application. The AHP is also applied under fuzzy conditions by Mohanty et al., and Tolga [91] and [81]. Mohanty et al. [91] incorporate basic, applied, and development research, including risk and organizational aspects; however, the analysis is theoretical and has no application case. In the case of Tolga [81], the fuzzy multi-criteria analysis is generated by the fuzzy TOPSIS method mixed with real option valuation. The analysis is based on options, and incorporates time and multiple criteria analysis; however, this is a mathematical analysis and lacks application. There are other methods applied by Ashrafi et al., and Hashemkhani Zolfani et al. [12] and [10] such as Decision Support System (DSS) and Weight Assessment Ratio Analysis (SWARA); however, similar to the 
other cases, the methods are too complex and do not consider a holistic analysis. Moreover, in the case of Hashemkhani Zolfani et al. [10], the criteria are not used for ranking and do not have hierarchies, showing a very simple weighting method.

Few studies incorporate into their analysis the long-term strategy elements and characteristics of R\&D projects. Optimal sequence and optimal analysis are used by Chun and Lauritzen [93] and [26]. In these studies, the selection of projects is related to time, and are based on NPV and probability estimations. However, the analysis is done in a mathematical context, focusing on cash flows and costs. Another group of studies, including Huang et al. [27], uses the fuzzy analytic hierarchy process method AHP for government-sponsored projects. However, the organizational strategy is not included explicitly, and the projects are focused on technologies that will compete in the market. Additionally, the model only considers criteria and sub-criteria but no alternatives.

Organizational strategy is a factor that is not explicitly considered in the models. Ringuest et al. [8] use a probabilistic financial portfolio optimization, but only monetary aspects are taken into account. Most of the studies are focused on economic analysis. These studies focus on the monetary analysis of the variables using many types of methods. Lauritzen and Lawson et al. [26] and [14] analyze the portfolio as a multi-criteria model. The optimal analysis is based on probabilities, and only focuses on costs or has limited use of criteria and factors. Moreover, project selection is weighted individually and not as a portfolio in a simplistic version. Other studies incorporate uncertainties in the portfolio selection and the flexibility of decision making by using an options approach. Additionally, their analysis incorporates the interdependency among the projects and the sequential time 
approach. The monetary valuation is done using real valuation, NPV, linear optimization, or hybrid methods that incorporate uncertainties and fuzzy analysis [13], [19], [93], [94], [85], [11], [22], [23], [30], [6], [95], [90], [8], [96], [87].

\subsubsection{Gaps by Related by Topic}

The literature search is based on four important points: studies about R\&D project selection or portfolio selection, those in power transmission utilities, studies regarding nonprofits, and studies on regulated organization characteristics.

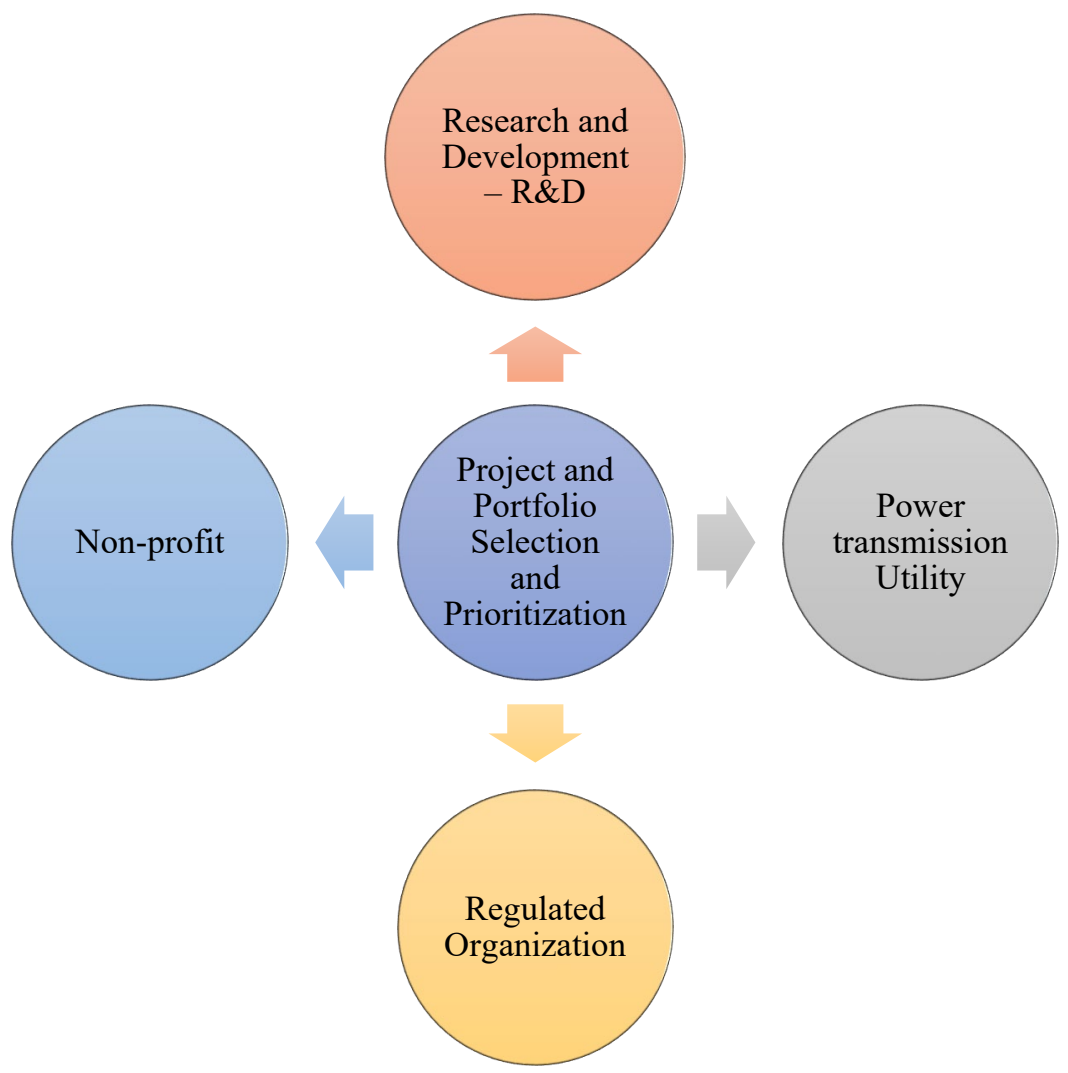

Figure 13: Literature Search Criteria 
As it is shown in Table 13, a complete analysis of studies about R\&D project or portfolio selection has been made. The search has been performed by using Scopus as a database focused on project and portfolio selection and prioritization topics. The findings show that topics related to R\&D project selection are the most common topics (199 documents); however, topics related to $\mathrm{R} \& \mathrm{D}$ project selection and non-profit organizations, regulated organizations, power transmission utilities are much less. The most important gaps are related to studies that examine combined or topics relating to two or more organizational characteristics. The most relevant finding is that there is no study about power transmission that considers non-profit and regulated utilities.

Table 13: Studies about Project and Portfolio Selection and Prioritization

\begin{tabular}{|c|c|c|c|c|c|c|}
\hline \multicolumn{6}{|c|}{ Project and Portfolio Selection and Prioritization } & \\
\hline & & \multicolumn{2}{|c|}{$\begin{array}{c}\text { Research } \\
\text { and } \\
\text { Development } \\
\text { - R\&D }\end{array}$} & & $\begin{array}{c}\text { Regulated Organiza } \\
\text { tion }\end{array}$ & $\begin{array}{c}\text { Power transmission } \\
\text { Utility }\end{array}$ \\
\hline & & \multicolumn{5}{|c|}{ References } \\
\hline $\begin{array}{l}\text { Research and } \\
\text { Development - } \\
\text { R\&D }\end{array}$ & \multirow{4}{*}{ 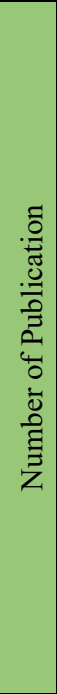 } & 199 & & {$[97]-[100]$} & $\begin{array}{c}{[97],[98],[100],} \\
{[101]}\end{array}$ & $\begin{array}{c}{[102],[103],[112]-} \\
{[116],[104]-[111]}\end{array}$ \\
\hline Non-profit & & \multicolumn{2}{|c|}{4} & & $\begin{array}{c}{[97],[98],[100],} \\
{[101]}\end{array}$ & NONE \\
\hline $\begin{array}{c}\text { Regulated } \\
\text { Organization }\end{array}$ & & \multicolumn{2}{|c|}{4} & 4 & & {$[141]-[145]$} \\
\hline $\begin{array}{c}\text { Power } \\
\text { transmission } \\
\text { Utility }\end{array}$ & & \multicolumn{2}{|c|}{14} & 0 & 5 & $\begin{array}{c}{[142],[146],} \\
{[155]-[164],} \\
{[147],[165]-} \\
{[174],[148],} \\
{[175]-[184],} \\
{[149],[185]-} \\
{[188],[150]-} \\
{[154]}\end{array}$ \\
\hline
\end{tabular}


It is possible to observe the differences in the amount of research that has been made in each area and in joint topics. There is a significant difference between a large number of publications about R\&D project selection in general and the few studies addressing the same topic for public and non-profit power utilities. Moreover, the studies focusing on power transmission utilities are nonexistent. The most significant publications in the field of energy and power utilities are focused on ex-ante and ex-post evaluating projects and existing technologies, and they do not consider important aspects of the characteristics of the organization.

As was explained, the necessity of select R\&D projects to invest under budget restrictions was addressed extensively in the literature. As it is shown in Table 14: R\&D Project Selection Methods and Gaps, the most relevant methodologies are focused on economic models (financial methods), mathematical programming, and portfolio optimization. The financial analysis is used based on monetary variables and mostly uses costs and revenues as the main variables. 


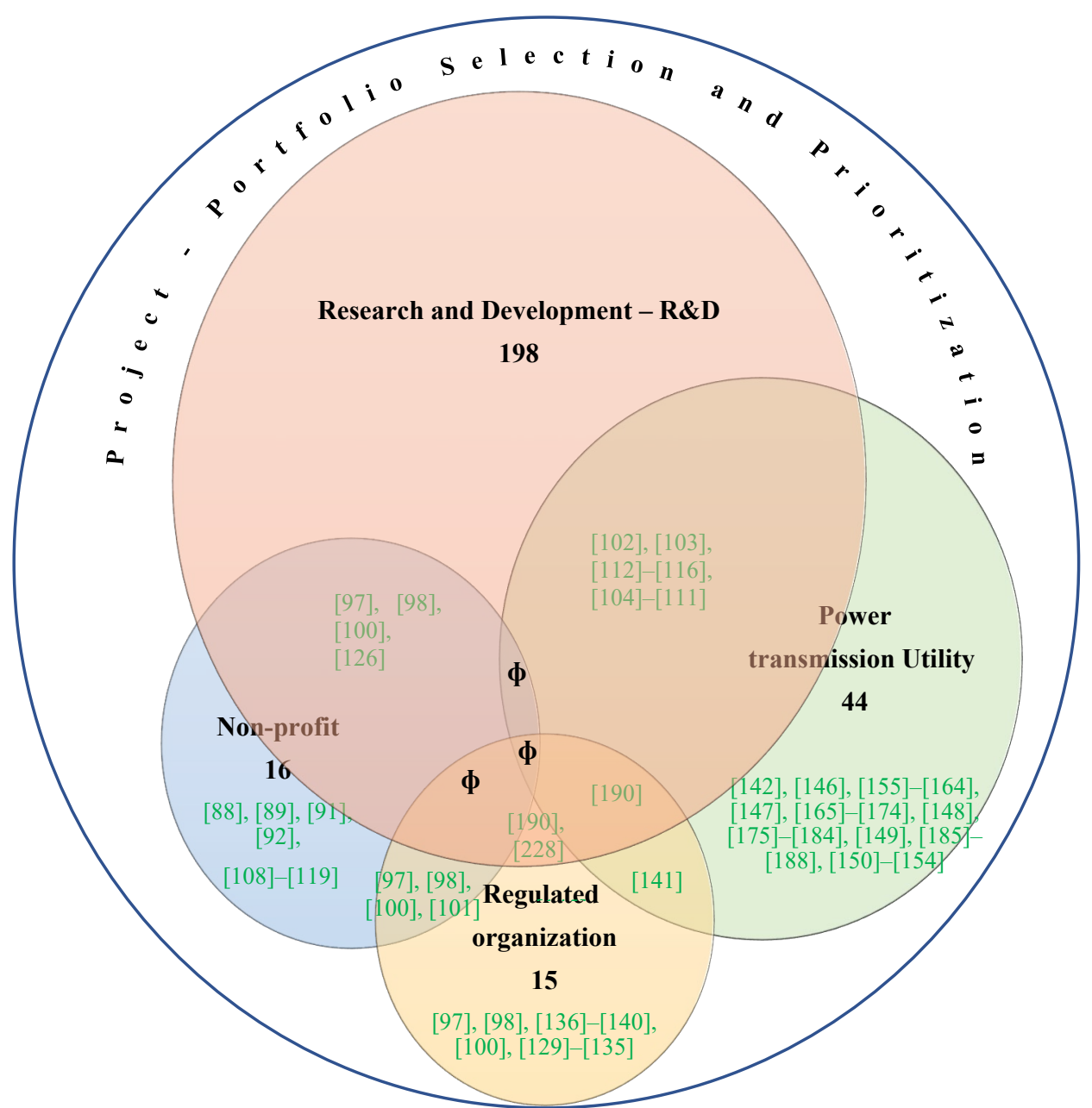

Figure 14:Studies about Project and Portfolio Selection and Prioritization

There are no studies that relate to the focus of selecting R\&D projects by non-profit, regulated power transmission utilities. As it is observed, the intersection of these conditions is null. Some studies have focused only on two conditions (non-profit and regulated, regulation and power transmission utilities).

In general, in the transmission sector, most of the studies focus on analyzing the selection and evaluation of projects for existing technologies. The necessity of expanding and maintaining power grids requires that there are permanent updates of the power 
transmission lines. These need to be considered for planning and operations. The evaluation of projects has been done by using different methodologies, mainly based on probabilistic and probabilistic analysis, to optimize the system where the evaluations tend to consider technical, financial, and social aspects. One of the most important factors considered is the reliability of systems, incorporated into the models through probabilistic risk indexes such as in the studies of Lu and Nagle et al. [163], [164], and [167]. The evaluation of power transmission projects uses probabilistic analysis by incorporating into the model fuzzy elements such as noted in the study of Li et al., Liang et al., and Zhang et al. [189], [159], and [184]. The most important aspects to be highlighted from these studies are that evaluation of the transmission projects consider the risk, costs, and reliability, and are framed into probabilistic and mathematical methodologies.

As it was described above, the concepts of non-profit, regulated, and public organization are interrelated. In the area of transmission power utilities, the system is regulated since it corresponds to the formation of natural monopolies, high capital, and no physical feasibility of competition. The most important aspects that are considered in the regulations are the cost optimality and the reliability of a system capable of supplying the required levels of demand. However, there are no studies that explicitly integrate the regulatory, non-profit, and public characteristics of the organizations. Fernandez et al. [97] use a mathematical and computational approach to select $R \& D$ projects in public organizations. The aspects evaluated are economic, social, scientific, and human resources, and they are integrated with organizational aspects such as leadership, infrastructure, and the environment. Litvinchev et al. [98] focuses on large-scale public (non-profit) 
organizations and uses a non-linear optimization model to the available funds (based on cost information) to optimize the $\mathrm{R} \& \mathrm{D}$ project selection. From more specific government non-profit organizations, Pereira and Veloso [100] uses Markowitz's portfolio optimization, pointing to budget allocation and estimations of risks. The only identified study focusing on regulated electric utilities is made by Morton et al. [190]; however, this study only describes the most used methods to analyze R\&D portfolio optimization remarking the multi-criteria methods as the most important.

Linton et al. [191] presents a list of methodologies that are used to evaluate R\&D projects and portfolios. The most known methods are call options, effectiveness index, NPV, IRR, and DCF. The financial analysis considers monetary variables, and mostly uses costs and revenues as the main variables. A common method that has been used in $R \& D$ project evaluation is based on economic or financial analysis. The economic/financial analysis is framed in capital budgeting methods such as Net Present Value (NPV), payback period, and rate of returns on investments. However, these methods have been associated with evaluating R\&D project problems, such as the difficulty in measuring the contribution of projects and estimation for long periods of monetary variables [192].

Since $R \& D$ projects are focused on creating new technologies, the lack of historical information on financial variables is treated with uncertainty. The inclusion of uncertainties and risk evaluation is a characteristic related to $R \& D$ project selection and evaluation. Gottardi et al. [193] framed the evaluation based on a computerized method that ranks R\&D projects from multiple perspectives and takes into consideration NPV, IRR, and payback. In this case, the financial or economic evaluation methods have been 
considered inappropriate for the specific evaluation of R\&D investments. Carlsson et al. [194] remarks on this inappropriateness of financial methods, and indicates that R\&D investments can be treated as the price of an option, proposing a fuzzy real options approach to evaluate R\&D projects. Many other studies use the same idea, such as [195][204], differing among them by the inclusion of fuzzy analysis, but all of them remark on the existence of uncertainties about investment costs and cash flows as characteristics of new technologies. Additionally, to price or cost uncertainties, other studies consider the market uncertainty, such as [197], [199], [205], [206]. Even more, technical uncertainties have been incorporated into the model's evaluations, such as [206] evaluated together with market or financial uncertainties. The real option has been performed as an option of evaluating projects; however, the use of probabilistic techniques is often used, especially for integrating technical uncertainties.

From a multi-criteria point of view, studies have focused on different variables or criteria, depending on the specific objectives of the analysis. As it is described before, modeling by using MCDM differs among them depending on the criteria or sub-criteria that were taken into account, and the method that was used like AHP, ANP, HDM, TOPSIS and more. The AHP and HDM share the same logic structure differentiated by the weighing scale. The AHP is the most common method used in R\&D project selection, and which was extensively used by authors such as [100], [129], [213]-[216], [191], [192], [207]-[212]. The HDM uses a scale of 1-100, and it has been used for evaluating R\&D projects in a few studies, such as [128], [192], [215]. The AHP method was developed by 
Saaty (1980), and like HDM, it is a method that structures complex problems into a hierarchy structure [192].

Analyzing R\&D projects by internal or external conditions, and the specific type of investment by non-public and regulated organizations has not been done extensively. Mostly, the evaluation methods are framed into mathematical modeling. Fernandez et al [97] uses a linear integer-mixed approach for evaluating $R \& D$ projects in public organizations. Other studies such as [98], [99], [100], [129], [100] use the same approach, linear optimization, but they vary in the use of different objective functions or constraints. When integrating different conditions of organizations, the methods become complicated, as is the case with the [207] analysis of public organizations.

The tables show a complete absence of literature to address the topic of evaluating R\&D projects in non-profits and regulated organizations. More specifically, in the context of electric transmission utilities, the topic has not been studied yet. It is important to remark that non-profit and regulated terminologies have been used interchangeably sometimes. In reality, even non-profit organizations can focus on public goods or services; the regulation aspects are differentiated by the external conditions that organizations need to accomplish. In the case of electric transmission utilities, regulation plays an important role since it is associated with market failure, and, as it is shown in the business models, it plays a crucial role in integrating the entire electric business system. Electric transmission utilities have been regulated in order to minimize costs (economic optimization of the systems) while maintaining the quality of the product and service, including the reliability of systems, and capability of transmission of the required power. 


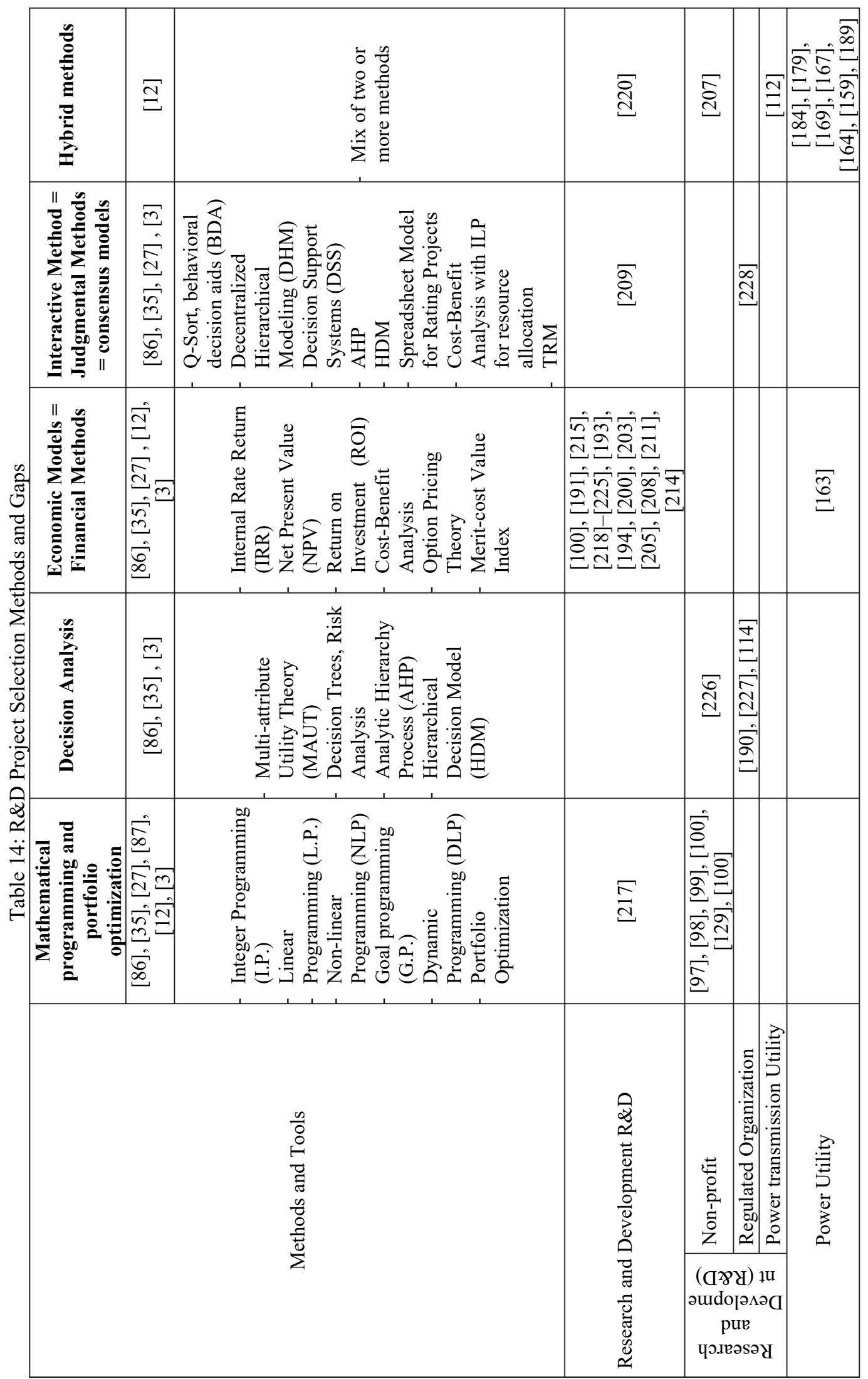


Table 15: Criteria and Sub-criteria According to Type of Organization

\begin{tabular}{|c|c|c|c|}
\hline R\&D in general & Non-profit & Regulated & $\begin{array}{c}\text { Power } \\
\text { Transmission } \\
\text { Utility }\end{array}$ \\
\hline$[212],[215],[214],[211]$ & $\begin{array}{c}{[97],[128],[226],} \\
{[126]}\end{array}$ & [227], [114] & $\begin{array}{c}227],[114], \\
{[169],[179],} \\
{[189]}\end{array}$ \\
\hline $\begin{array}{ll}\text { - } & \text { Scientific \& Technological merit } \\
& \text { (technological factors) } \\
\text { - } & \text { Potential benefits Economic } \\
& \text { (economic return) } \\
\text { - } & \text { Project execution } \\
\text { - } & \text { Project risk } \\
\text { - } & \text { Market potential } \\
\text { - } & \text { Strategic factors } \\
\text { - } & \text { Organizational factors } \\
\text { - } & \text { Actors }\end{array}$ & $\begin{array}{ll}\text { - } & \text { Economic } \\
\text { - } & \text { Social } \\
\text { - } & \text { Scientific } \\
\text { - } & \text { Human resources } \\
\text { - } & \text { Leader quality } \\
\text { - } & \text { Infrastructure } \\
& \text { quality } \\
\text { - } & \text { Environment } \\
\text { - } & \text { Strategic } \\
& \text { planning }\end{array}$ & $\begin{array}{ll}\text { - } & \text { Technical } \\
\text { - } & \text { Corporate } \\
& \text { and strategic } \\
\text { - } & \text { Regulatory } \\
\text { - } & \text { Market } \\
\text { - } & \text { Financial } \\
\text { - } & \text { Economic } \\
\text { - } & \text { Acceptance } \\
& \text { of } \\
& \text { stakeholders }\end{array}$ & $\begin{array}{ll}\text { - } & \text { Technical } \\
\text { - } & \text { Regulatory } \\
\text { - } & \text { Market } \\
\text { - } & \text { Financial } \\
\text { - } & \text { Economic } \\
\text { - } & \text { Regulation } \\
\text { - } & \text { Acceptance of } \\
& \text { stakeholders } \\
\text { - } & \text { Financial risk } \\
& \text { [179] } \\
\text { - } & \text { Reliability } \\
\text { - } & \text { Environment } \\
\text { - } & \text { Power grid } \\
& \text { property } \\
\text { - } & \text { Regional } \\
& \text { economic } \\
\text { - } & \text { Social } \\
& \text { Benefits }\end{array}$ \\
\hline
\end{tabular}

Based on Table 15, it can be observed that non-profit organizations emphasize social aspects while regulated organizations distinguish economic and financial aspects. Differentiating financial and economic aspects shows the intrinsic definition of economic aspects that not only consider financial aspects but social costs and benefits. In power transmission utilities, the economic and financial aspects are included in the list of criteria that consider regulatory and technical factors, as well as the reliability and the properties of the power grid. 


\subsection{Research Questions}

R\&D project selection model is investigated and an HDM model is elaborated supporting strategic decision making for electrical utilities.

\section{The main question is:}

What criteria and sub-criteria affect $\mathrm{R} \& \mathrm{D}$ project selection based on a holistic approach to align with strategies and market structure in the regulated transmission power sector?

\section{The specific questions are:}

- What are the criteria and sub-criteria associated with $\mathrm{R} \& \mathrm{D}$ project investment decisions in power transmission projects?

- What are the levels and weights of criteria and sub-criteria associated with R\&D project selection in power transmission projects?

- $\quad$ How do changes of criteria impact on R\&D project selection?

\subsection{Research Gaps, Objectives \& Questions}

Based on the research gaps, research objectives, and research questions, the figure below shows these three aspects in summary: 

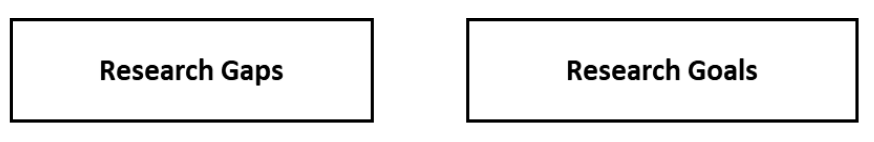

Research Questions

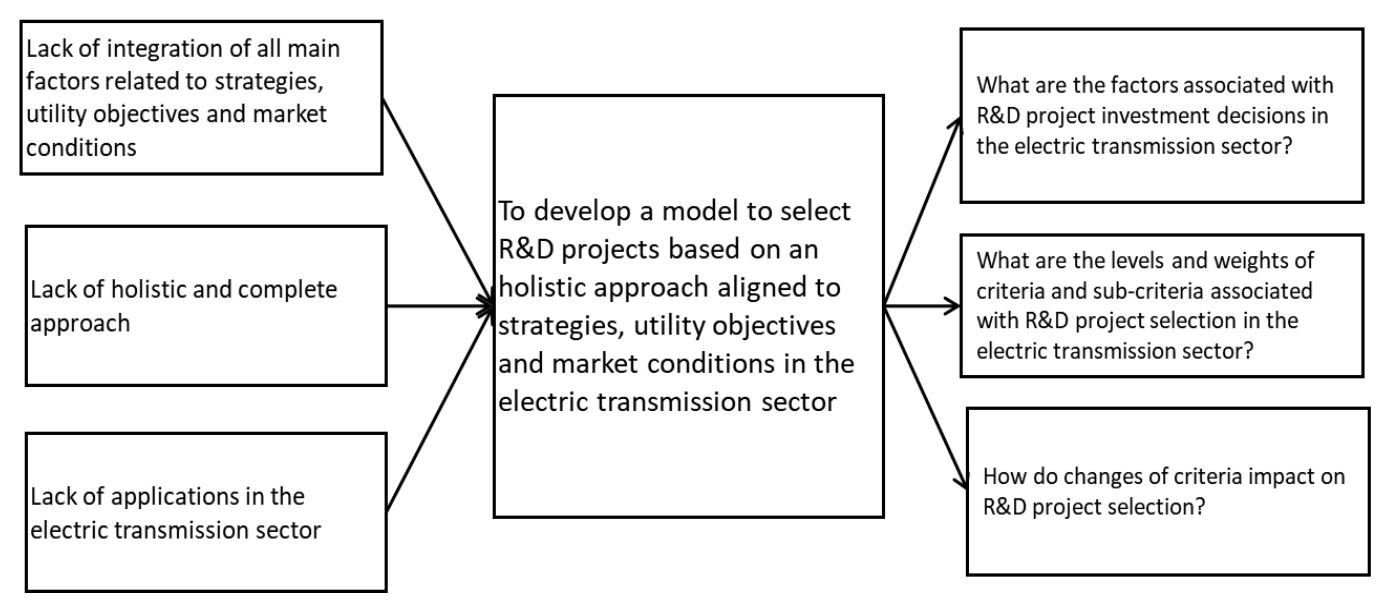




\section{CHAPTER 4: RESEARCH APPROACH AND METHODOLOGY}

Hierarchical Decision Model (HDM) [1]is an approach developed by Kocaoglu [1] for multicriteria decisions. As its similar approach to Analytical Hierarchy Process (AHP) [229], HDM is based on hierarchical structure and pairwise comparisons. HDM was selected as the method to evaluate R\&D projects, describing the methodology and strategy below.

\subsection{Research Methodology}

To have an effective R\&D project selection analysis, a holistic analysis that considers all factors associated with projects in the transmission power sector is necessary. There are no studies about holistic assessment focusing on power transmission project selection. Applying a Hierarchical Decision Model (HDM) is an effective tool for the assessment of $R \& D$ projects. The methodology and results of this study analyzes the factors associated with electric power technologies and complements the evaluation of other methodologies.

The research fits into the evaluation, selection, and prioritization of R\&D projects process. The model is a complement to other methods to improve the R\&D project selection in the transmission power sector. The figure below represents the research focus in the entire R\&D portfolio selection cycle. 


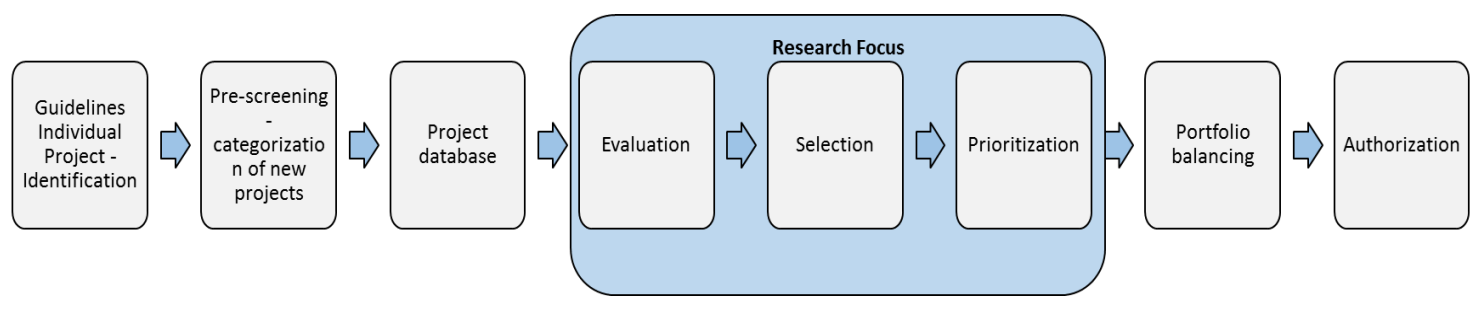

Figure 15: R\&D Project Portfolio Selection Framework

\subsection{Research Approach}

The following steps is applied to develop the research; these steps include the development of a hierarchical decision model:

Figure 16: Research Approach - Phases

Phase 1: A literature review on R\&D projects. The project selection focused on the power

Phase 1

Literature Review

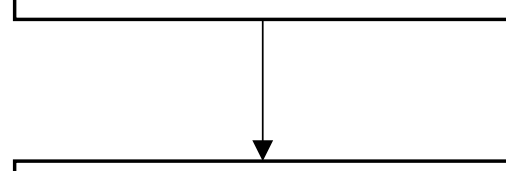

Phase 2

Hierarchical Model

Development

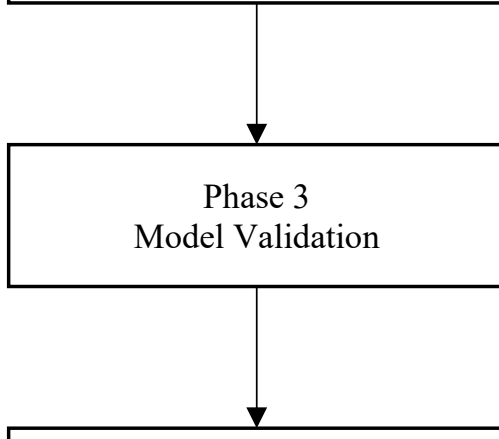

Phase 4

Using HDM to Quantify

Experts' Judgements
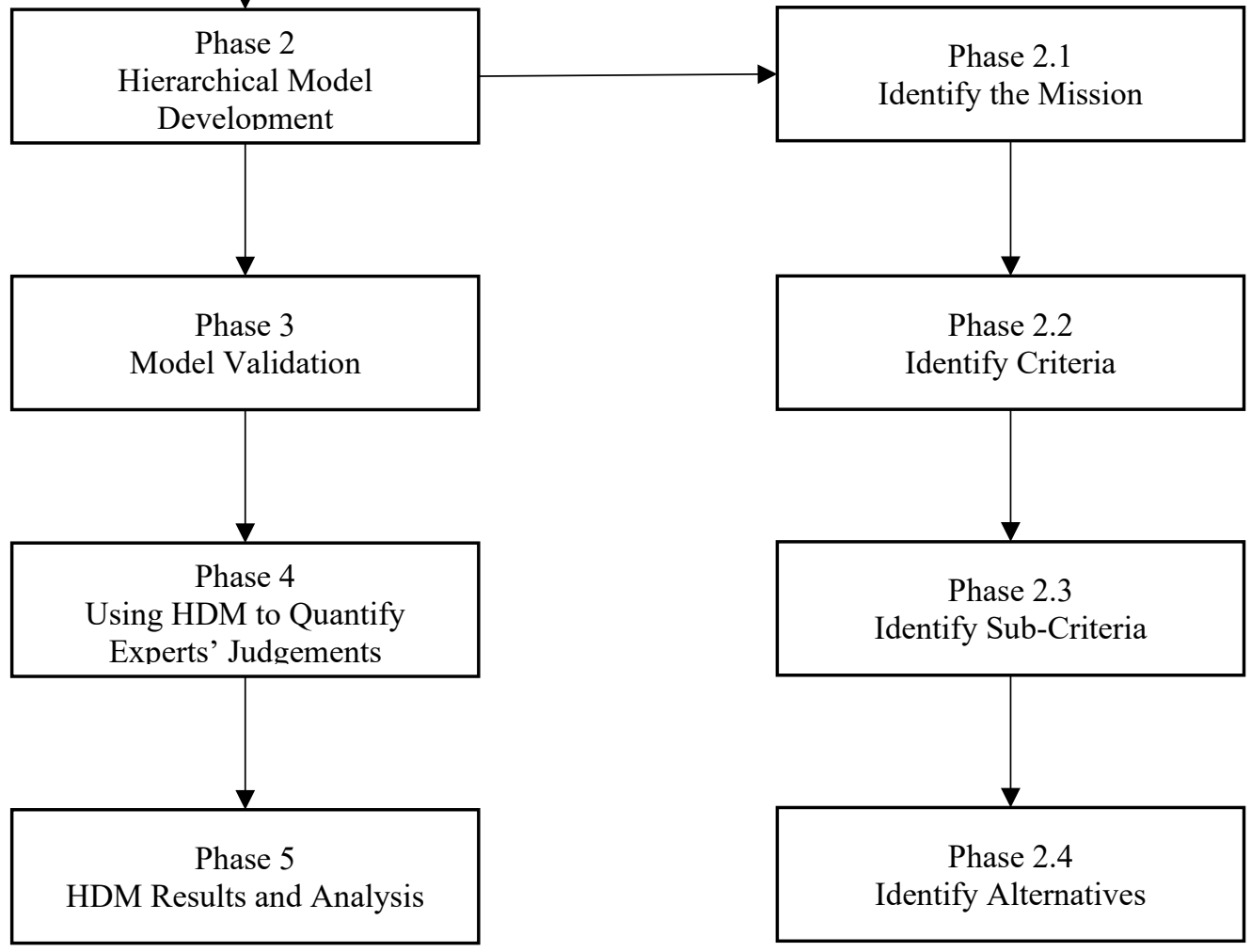

sector has been done. 
Phase 2: Development of a hierarchical model structure to illustrate the multilevel structure based on the variables identified from the literature. This includes a hierarchical model structure, including layers, criteria, sub-criteria, and alternatives. Factors are defined and classified, ensuring to be differentiators to the alternatives.

Phase 3: Variables, factors, and structure of the model are evaluated by experts from an electrical utility and experts associated with the field. The expert panels are from a different range of utility operations expertise.

Phase 4: Pairwise comparison research instruments are employed to quantify the relative weights of the variables in each level of the hierarchical structure.

Phase 5: The results of experts' judgments are discussed and validated. 


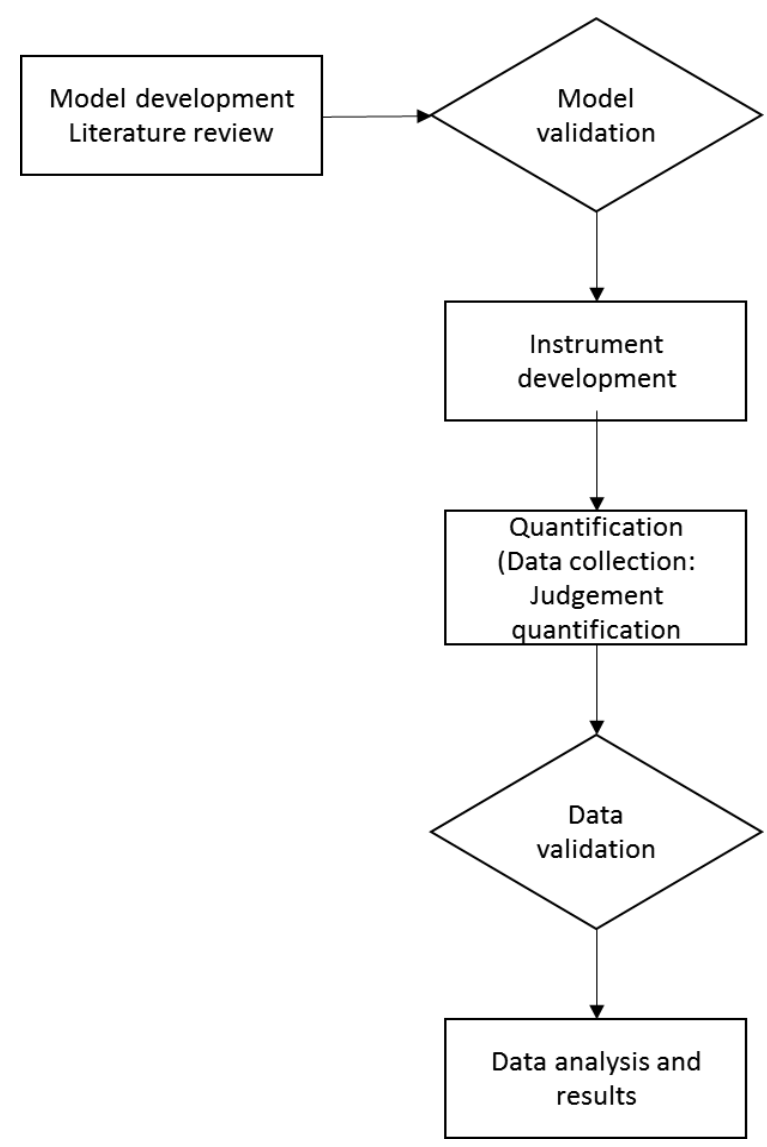

Figure 17: Model Development Phase - Literature Review - Research Application

Based on the revised preliminary assessment model, content validity instruments are designed and sent to experts. The expert panels are used to demonstrate the development, quantification, and implementation of the HDM model.

\subsection{Justification of the Method}

Evaluating R\&D projects is complex and requires a holistic analysis of criteria and factors. Moreover, the multiple types of variables and factors affecting the decision in the energy sector cannot be analyzed partially and are made under monetary considerations. Criteria and sub-criteria can be qualitative and quantitative, and decision-makers act 
according to subjective perspectives [230]; therefore, a multi-criteria decision analysis allows an integrated and comprehensive decision and analysis.

The current models evaluating the R\&D investment decisions are complex, and most of them are not easy to be developed by managers in real situations [35], [19]. One of the main concerns is to deal with the imprecision of statistical calculations and assumptions, especially in the aspect of future cash flow. Therefore, HDM appears to be a method that eliminates this problem [13].

There is evidence that organizations that incorporate scoring methods, generally outperformed companies using only financial evaluation [14]. The evaluation and strategic aspects require a methodology that is structured as a hierarchy [6]. The HDM can be used at any stage of evaluating the R\&D portfolio, and most importantly, it can be used in the initial stage, before investing in the project. Since HDM is a quantitative method, it prevents internal disagreement among decision-makers and performs an unbiased process [231].

The main reason that HDM is used is that it considers all the main factors associated with the type of organizations in the electric transmission sector (natural monopolies characteristics and those considered public, non-profit organizations). Applying the Hierarchical Decision Model (HDM) is an effective way of evaluating R\&D projects because it considers all criteria and sub-criteria and organizes them into a hierarchy. The methodology and results of this study analyzes the technologies associated with the electric power sector and complement the evaluation of other methodologies. 


\subsubsection{Financial Analyses for Transmission Technology R\&D Project Decision Making in the Context of Transmission Utility}

The analysis of $R \& D$ projects requires qualitative and quantitative variables. Moreover, the characteristics of public and regulated electric utilities influence the decisions of R\&D investments. Financial methods do not consider all the aspects and only focus on specific estimated data (financial aspects). As it was analyzed to evaluate R\&D projects in the electric transmission sector, it needed to also consider technical and economic factors; moreover, since the organizations are public and non-profit, social and regulatory factors influence the success of the projects. Since there are many types of variables affecting the decision of investing in $\mathrm{R} \& \mathrm{D}$ projects in organizations such as BPA, the type of information or needed data and the quantitative and qualitative characteristics of holistic analysis is not performed using financial methods.

Even the HDM can be considered as a subjective method; the financial methods have their weaknesses for analyzing $R \& D$ projects. In electric transmission technologies, the adaptability of the optimal costs is adjusted periodically because of the market dynamics and variability of costs. For that, financial analysis adjusts and assumes future costs under high risk (because of changes in data or patterns). Since the evaluation of R\&D projects corresponds to an organization considered as public and non-profit, the economic, social, and political aspects need to be taken into account for evaluating R\&D projects. Therefore, the objectives and strategies of this type of organization are different from other private sectors. Financial methods ignore these aspects, especially considering the objectives and strategies of the organizations. 
Financial methods are used on individual project evaluations. This aspect, combined with focusing only on monetary aspects (not holistic), cannot provide an accurate ranking of projects. This can be seen in the case of the size of organizations and the size of projects. The Power Market Administrators (PMA) such as BPA is considered a large organization.

\subsection{Hierarchical Model Development}

The model development was conducted based on the literature review. Based on this literature review, a preliminary assessment model was created. The comprehensive literature review was done in the area of power transmission $\mathrm{R} \& \mathrm{D}$ projects. The variables were categorized according to the criteria and sub-criteria (technical, market, economic, organizational, and environmental/regulation).To quantify the HDM, experts were identified and asked to weight the criteria and alternatives of the model.

\subsection{Validation of the HDM Model}

The preliminary model was sent to experts EP01 and EP02 for validation using research instruments 1 (RI1 and RI2 for criteria and sub-criteria validation, respectively).

Experts determined which criteria should and should not be included. A two-thirds $(67 \%)$ consensus process was used to include the criterion in the model.

Experts could also add a new factor(s) using research instruments. Again, if twothirds $(67 \%)$ of experts agreed to the new factor(s), it was included in the current model. 
The preliminary model was sent to EP01 and EP02 for validation using Research Instrument 1 (RI1 and RI2 for criteria and sub-criteria validation, respectively).

RI1 and RI2 were used for criteria and sub-criteria validation by expert panels. EP01 determined which criteria should and should not be included. EP02 determined which criteria should and should not be included. The validation process took several iterations. R11 and RI2 were conducted using web-based survey tool Qualtrics. A two-thirds (67\%) consensus process was used to include the criterion in the model. A form of the instrument template is provided in Appendix A. Descriptions of all criteria and sub-criteria are also provided in Appendix A.

EP01 and EP02 could also add a new factor(s) using RI1 and RI2. Again, if twothirds $(67 \%)$ of experts agreed to the new factor(s), it was included in the current model.

A total of 9 experts were contacted and provided information for the model validation and quantification parts. Criteria were validated by expert panel EP1 (9 people), and sub-criteria were validated by expert panel EP2 (6 people).

\subsection{Judgment Quantification}

Experts provide pairwise comparisons among the different elements of the model. In this case, the HDM has four levels (mission, criteria, sub-criteria, and alternatives); therefore, experts provide pairwise comparisons among criteria with respect to the mission, pairwise comparisons among sub-criteria with respect to each criterion, and finally pairwise comparisons among the alternatives with respect to each sub-criterion. The following is a summary of nomenclature and functions of how the weights are calculated: 
Mission: To evaluate a multi-perspective R\&D for project selection in the transmission power sector.

Criteria: Criteria $\mathrm{k}$ under the mission: $\mathrm{C}_{\mathrm{k}}$, with $\mathrm{k}=1, \ldots, \mathrm{K}$.

Sub-criteria: Sub-criteria 1 under the Criteria k: Slk, with $1=1, \ldots, \mathrm{L}$.

Step 1: Quantification of the relative importance of criteria.

Quantify expert judgment to obtain the relative importance of $C_{k}$ concerning its contribution to the mission.

Step 2: Quantification of relative importance of sub-criteria.

Quantify expert judgment to obtain the relative importance of $S_{l k}(1=1, \ldots, L)$ with respect to its contribution to $\mathrm{C}_{\mathrm{k}}$.

Step 3: Quantification of relative importance of transmission $R \& D$ project alternatives.

Quantify expert judgment to obtain the relative importance of $\mathrm{Am}(\mathrm{m}=1, \ldots, \mathrm{M})$ with respect to its contribution to Sik. 
Step 1: Quantification of relative importance of criteria.

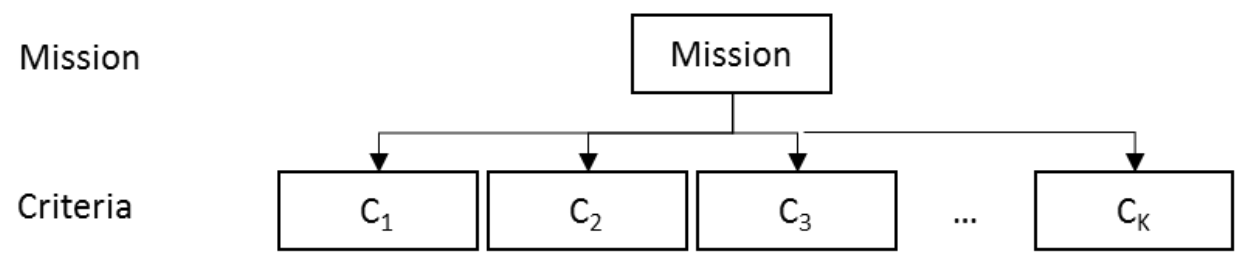

Step 2: Quantification of relative importance of Sub-criteria.

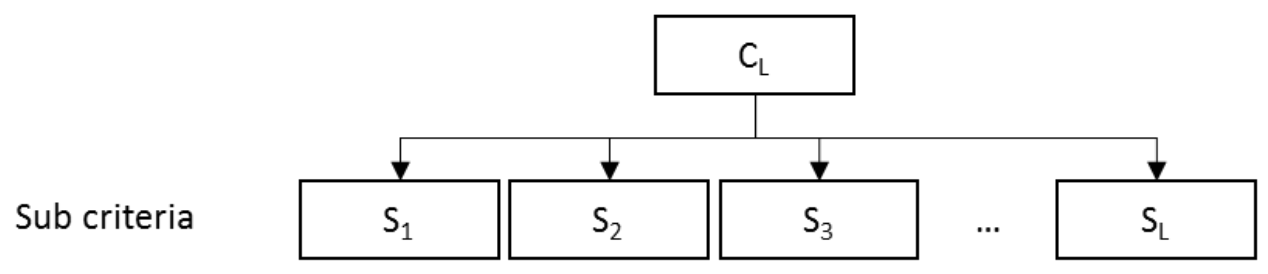

Step 3: Quantification of relative importance of transmission R\&D project alternatives

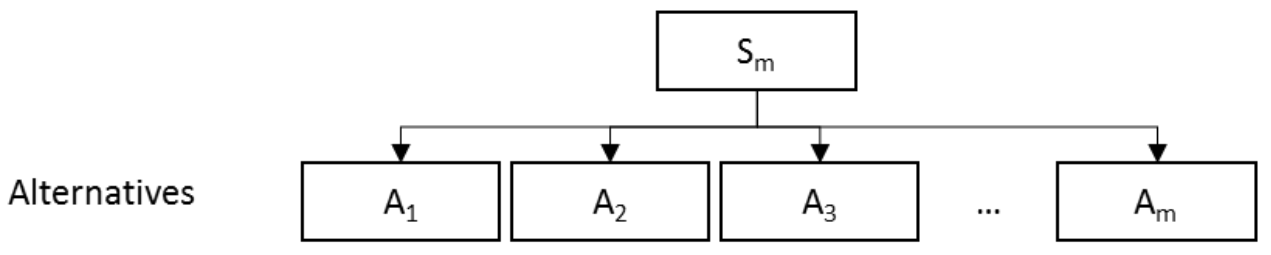

Step 4: Calculation of the overall relative value of $R \& D$ project alternatives.

The calculation of the relative values are based on:

$$
V A_{m}=\sum_{k=1}^{K} \sum_{L=1}^{L} V\left(C_{k}\right) \cdot V\left(S_{L k}\right) \cdot V A_{m L k}
$$

Where: $\mathrm{V}\left(\mathrm{A}_{\mathrm{m}}\right)=$ Overall relative $\mathrm{R} \& \mathrm{D}$ project value 


\subsection{Content and Construct Validity}

Identifying experts and forming panels is very important for the judgment of the model in its different levels. In general, there are five steps for panel formation to minimize any potential bias [232], [233].

There are two concepts to be defined: What is an expert and what is an expert panel [234]. An expert is a person who has the relevant knowledge and experience, and whose opinions are esteemed by peers in his or her field [235], [236]. An expert panel is analyzed by Estep [237], who mentioned that an expert panel is a group of individuals with access to current, high-quality information on a related topic [238].

However, identifying experts and forming panels is challenging. The decisionmaking process needs to have the right experts to ensure reliability when thoughts and opinions are used [235].

Both the concepts and the experts, along with the expert panel, are linked by a common characteristic of having specific knowledge [234] and have access to information or experience. Therefore, the issues of forming panels are highly related to issues of identifying experts. Below, the identification of the issues is focused on two groups-one about issues associated with forming experts, and the other one with the issues associated with identifying experts.

\subsection{Selecting Experts}

It is essential to know who the experts are because there are many problems that can arise from using non-competent experts. The main issues associated with identifying 
experts are regarding the qualifications of the experts and related to the knowledge that these people have about a certain topic. Therefore, as Abotah and Estep [235] and [237] stated, these are the main criteria to take into account when selecting experts:

The experts need to have experience and need to be contributing to the study field. As stated above, it is crucial that they have access to the information. According to Estep [237], this includes individuals' scientific or technical education. Stitt-Gohdes et al. [239] mentioned this aspect as expert qualifications.

Experts and the panel need to be unbiased. For this issue, the experts cannot have any conflicts among the panelists and must be selected from multidisciplinary fields.

The experts need to be willing to participate, their participation should be voluntary, and their judgment needs to be free of any external influence. At the same time, the expert needs to have relevant publications and patents [239] and an advanced degree in the relevant field or relevant awards. Additionally, Estep [237] mentions about additional conditions that expert panels need in order to have the skills to communicate the entire context and purpose of the study and the information.

The panel size should be determined to have reliable information [237], [239]. For example, very large panels could have coordination problems, or very small panels could not be beneficial since experts could think that it is not an obligation to participate [240].

Following the theoretical criteria to select experts and the analysis strategy by Estep; Gibson; Phan [232], [237], [241], the model was validated by experts EP01 and EP02. These two expert panels validated the criteria and sub-criteria respectively in 
iteration until consensus was reached. For the validation, the research instruments RI1 and RI2 were used based on surveys for data collection built-in Qualtrics [242].

Research instrument 3 (RI3) was used by expert panel 1 (EP1) to evaluate the relative importance of the criteria with respect to the mission. Research instrument 4 (RI4) was used by EP2 to evaluate the relative importance of sub-criteria with respect to the criteria. Table 16 below summarizes the expert panels and research instruments' information.

Table 16: Expert Panel Design

\begin{tabular}{|c|c|c|c|c|}
\hline $\begin{array}{c}\text { Panel } \\
\#\end{array}$ & $\begin{array}{c}\text { Research } \\
\text { Instrument }\end{array}$ & Step 1 & Step 2 & Size \\
\hline EP01 & RI1 & \multicolumn{2}{|c|}{ Criteria validation } & $\begin{array}{c}6 \text { to } 18 \\
\text { participants }\end{array}$ \\
\hline EP02 & RI2 & \multicolumn{2}{|c|}{ Sub-criteria validation } & $\begin{array}{c}6 \text { to } 18 \\
\text { participants }\end{array}$ \\
\hline EP1 & RI3 & Quantify the contribution of each criterion to the mission. & $\begin{array}{c}6 \text { to } 11 \\
\text { participants }\end{array}$ \\
\hline EP2 & RI4 & $\begin{array}{c}\text { Quantify the contribution } \\
\text { of technical sub-criteria. }\end{array}$ & $\begin{array}{c}\text { Evaluate the relative contribution } \\
\text { of alternatives with respect to the } \\
\text { technical sub-criteria }\end{array}$ & $\begin{array}{c}6 \text { to } 11 \\
\text { participants }\end{array}$ \\
\hline EP2 & RI4 & $\begin{array}{c}\text { Quantify the contribution } \\
\text { of market sub-criteria. }\end{array}$ & $\begin{array}{c}\text { Evaluate the relative contribution } \\
\text { of alternatives with respect to the } \\
\text { market sub-criteria. }\end{array}$ & $\begin{array}{c}6 \text { to } 11 \\
\text { participants }\end{array}$ \\
\hline EP2 & RI4 & $\begin{array}{c}\text { Quantify the contribution } \\
\text { of organizational sub- } \\
\text { criteria. }\end{array}$ & $\begin{array}{c}\text { Evaluate the relative contribution } \\
\text { of alternatives with respect to the } \\
\text { organizational sub-criteria. }\end{array}$ & $\begin{array}{c}6 \text { to } 11 \\
\text { participants }\end{array}$ \\
\hline EP2 & RI4 & $\begin{array}{c}\text { Quantify the contribution } \\
\text { of economic sub-criteria. }\end{array}$ & $\begin{array}{c}\text { Evaluate the relative contribution } \\
\text { of alternatives with respect to the } \\
\text { economic sub-criteria. }\end{array}$ & $\begin{array}{c}6 \text { to } 11 \\
\text { participants }\end{array}$ \\
\hline RI4 & $\begin{array}{c}\text { Quantify the contribution } \\
\text { of environmental/ } \\
\text { regulation sub-criteria. }\end{array}$ & $\begin{array}{c}\text { Evaluate the relative contribution } \\
\text { of alternatives with respect to the } \\
\text { environmental/ regulation sub- } \\
\text { criteria. }\end{array}$ & $\begin{array}{c}\text { participants } \\
\text { pe } 11\end{array}$ \\
\hline
\end{tabular}




\section{Research Instruments 1 \& 2 (RI1 \& RI2)}

These research instruments are used to validate and the content of the model. The surveys ask experts for their agreement or disagreement to include or drop criteria and subcriteria. The experts had the opportunity to suggest the inclusion of new items, which were validated at $66.67 \%$ of the positive agreement for the inclusion. Additionally, the experts were asked to provide their comments, which are used to improve the concepts and clarify the contents.

\section{Research Instrument 3 (RI3)}

This research instrument is used to evaluate the relative priorities of the five criteria in fulfilling the mission of R\&D project selection in the electric transmission sector. Expert panel EP1 is responsible for fulfilling RI3. Based on judgments quantification from expert panel EP1, the arithmetic mean of the relative priority of the criteria to the mission and the levels of inconsistency and disagreement for the experts were obtained. The arithmetic mean of the panel's evaluation is used to represent the relative ranking of the criteria.

\section{Research instrument 4 (RI4)}

Research instrument 4 is used to evaluate the relative priorities of sub-criteria with respect to the five criteria. EP2 is responsible for fulfilling RI4. Based on judgments quantification from the expert panel, the arithmetic mean of the relative priority of the subcriteria to the criteria and the levels of inconsistency and disagreement for the experts is obtained. The arithmetic mean of the panel's evaluation is used to represent the relative ranking of the sub-criteria. 


\section{CHAPTER 5: DATA COLLECTION}

For the validation of the model, more than six experts were used in each panel. In the case of the quantification process, six to twelve experts are required per expert panel. Some experts belong to more than one panel. The identification of experts by expertise areas was conducted by using the Snowball Sampling Method (SSM) [243]. The general criteria for expert selection include the relevant expertise within the research area, availability and willingness to participate, and balanced perspectives and minimizing biases.

Additionally, experts are identified by using the Social Network Analysis (SNA) [244]. The criteria of this analysis are based on co-authoring SNA using basic research database information focused on papers about technology adoption and directly related to technologies and electrical utilities. The most important sub-networks were considered since this implies that the connection of authors and importance between them are highly related to the size of the network.

\subsection{Expert Panel Defined}

Identifying experts and forming panels is very important for the judgment of the model in its different levels. In general, there are five steps for panel formation to minimize any potential bias [232], [233].

There are two concepts to be defined: What is an expert, and what is an expert panel [234]. An expert is a person who has the relevant knowledge and experience and whose 
opinions are esteemed by peers in his or her field [235], [236]. An expert panel is analyzed by Estep [237], who mentioned that an expert panel is a group of individuals with access to current, high-quality information on a related topic [238].

However, identifying experts and forming panels is challenging. The decisionmaking process needs to have the right experts to ensure reliability when thoughts and opinions are used [235].

Both concepts, experts and expert panel, are linked by a common characteristic of having specific knowledge [234], and having access to information or experience. Therefore, the issues with forming panels are highly related to issues of identifying experts. Below, the identification of the issues is focused on two groups-one about issues associated with forming experts, and the other one with the issues associated with identifying experts.

\subsection{Forming Experts}

There are two important aspects to be considered when forming an expert panel:

First, a panel must be balanced with experts who have diverse areas of knowledge or expertise [235], and second, experts need to be knowledgeable about the domain and have a reputation for high-quality expertise [232].

The panel needs to be unbiased so as not to adversely affect the decision [235] [237]. 


\subsection{Data Analysis}

\subsubsection{Inconsistency Analysis and Group Disagreements}

\section{Inconsistency}

Inconsistency can be defined as the measure of disagreement within an individuals' opinions [237], [235]. The judgments are not perfect and consistent all the time; therefore, there is a level of inconsistency that can be tolerated. The acceptable level of tolerance of inconsistency is considered lower than 0.1 . If the inconsistency is greater than 0.1 , it is necessary that the individual revise their judgment values [235].

The measure of inconsistency has been discussed in many studies such as Abotah, Estep, Gibson, Iskin, and Phan [235], [237], [232], [89], [241]. The inconsistency measure is explained below:

For $n$ elements, the constant sum calculations result in a vector of relative values $r 1, r 2, \ldots$, $r_{n}$ for each of the $n$ ! orientations of the elements. For example, if three elements are evaluated:

$\mathrm{n}=3$,

Number of orientations $=n !=6$

The six orientations are: $\mathrm{ABC}, \mathrm{ACB}, \mathrm{BAC}, \mathrm{BCA}, \mathrm{CAB}$, and $\mathrm{CBA}$.

The relative values ( 6 orientations) are consistent if the pairwise comparisons given by the expert are consistent. In the case that the values and orientations are inconsistent, the relative values are different for each unique orientation. 
In the inconsistency measured by the variance among the relative values of the elements calculated in the $\mathrm{n}$ ! orientations,

Let:

$r_{i j}=$ relative value of the $i^{\text {th }}$ element in the $j^{\text {th }}$ orientation for an expert

$\bar{r}_{i}=$ mean relative value of the ith element for that expert

$$
\bar{r}_{i}=\left(\frac{1}{n !}\right) \sum_{j=1}^{n !} r_{i j}
$$

The inconsistency of the $\mathrm{i}^{\text {th }}$ element is:

$$
\text { Inconsistency }=\frac{1}{n !} \sum_{j=1}^{n !}\left(\bar{r}_{i}-r_{i j}\right)^{2}
$$

For:

$$
\mathrm{i}=1,2, \ldots, \mathrm{n}
$$

$\mathrm{n}=$ number of elements compared

$$
\text { Inconsistency }=\frac{1}{n} \sum_{i=1}^{n} \sqrt{\frac{1}{n !} \sum_{j=1}^{n !}\left(\bar{r}_{i}-r_{i j}\right)^{2}}
$$

There are other measures to use for analyzing inconsistency, which are not used in this research, such as the Abbas [245] new calculation using the root-sum of the variances (RSV) instead of the sum of the standard deviations [232]. To obtain a consensus of the experts' judgments, the reduction in disagreements needs to be done by a repetitive and dynamic process [230]. The inconsistency is evaluated by using the Root of the Sum of 
Variances (RSV) presented by Abbas [245]. Below is a summary of the calculation process of the inconsistency provided by Abbas [245]:

Table 17: Calculation of inconsistency by Abbas [245]

\begin{tabular}{|c|c|c|}
\hline$R S V=\sqrt{\sum_{i=1}^{n} \sigma_{i}^{2}}$ & $\begin{array}{l}\text { HDM } \\
\text { inconsistency }= \\
\text { Root of the Sum of } \\
\text { Variances (RSV) }\end{array}$ & $\begin{array}{l}\sigma i 2=\text { variance of the mean of the ith } \\
\text { decision element }\end{array}$ \\
\hline$\sigma_{i}=\sqrt{\frac{1}{n !} \sum_{j=1}^{n !}\left(x_{i j}-\bar{x}_{i j}\right)^{2}}$ & Standard Deviation & $\begin{array}{l}x i j=\text { normalized relative value of the } \\
\text { variable } i \text { for the jth orientation in } n \\
\text { factorial orientations } \\
\overline{x i j}=\text { mean of the normalized relative } \\
\text { value of the variable } i \text { for the jth } \\
\text { orientation }\end{array}$ \\
\hline $\bar{x}_{i j}=\frac{1}{n !} \sum_{j=1}^{n !} x_{i j}$ & $\begin{array}{l}\overline{x i j}=\text { mean of the } \\
\text { normalized relative } \\
\text { value of the } \\
\text { variable } i \text { for the } \\
\text { jth orientation }\end{array}$ & $\begin{array}{l}x i j=\text { normalized relative value of the } \\
\text { variable } \mathrm{i} \text { for the jth orientation in } \mathrm{n} \\
\text { factorial orientations }\end{array}$ \\
\hline
\end{tabular}

\section{Disagreements}

Disagreements among experts or groups of experts can be measured, and disagreement between experts is used to identify experts who have a significantly different opinion than the rest of the experts. Therefore, the disagreement of an expert is the deviation of the judgments of the experts with respect to the judgments of other experts [235]. Two measures can test disagreement of experts [235], the interclass correlation coefficient and the F-test. The F-test statistic can measure the disagreement. 
Judgment quantifications are done by using the constant sum method. Using of HDM Software [246] can verify the disagreement level. As Abotah, Estep, Gibson, Iskin, Phan [235], [237], [232], [89], [241] explain, the disagreement level calculation (interclass correlation coefficient) is shown below:

The interclass correlation coefficient (ICC) is a statistical measure that allows for knowing the degree of agreement between experts with respect to each other on the relative contribution of $\mathrm{n}$ elements in the comparison. The ICC describes the average correlation across all possible orderings of the judgments' matrices.

Table 18: Interclass Correlation Coefficient (ICC)

\begin{tabular}{|c|c|}
\hline Calculation & Nomenclature \\
\hline $\begin{array}{l}I C C=\frac{M S B S-M S R}{M S B S+(k-1)+\frac{k(M S B)-M S R}{n}} \\
\mathrm{MSBJ}=\frac{S S B J}{d f_{B J}} \\
S S B J=\sum_{j=1}^{k}\left[\frac{\left(\sum X_{j}\right)^{2}}{n}\right]-\frac{\left(\sum X_{T}\right)^{2}}{n k} \\
\mathrm{MSBS}=\frac{S S B S}{d f_{B S}} \\
S S B S=\sum_{i=1}^{n}\left[\frac{\left(\sum S_{i}\right)^{2}}{k}\right]-\frac{\left(\sum X_{T}\right)^{2}}{n k} \\
\mathrm{Df}{ }_{B S}=\mathrm{n}-1 \\
\mathrm{MSR}=\frac{S S R}{d f_{\text {res }}} \\
\mathrm{SSR}=S S T-S S B J-S S B S \\
d f_{\text {res }}=\sum X_{T}^{2}-\frac{\left(\sum X_{T}\right)^{2}}{n k}\end{array}$ & $\begin{array}{l}\text { ICC: Interclass correlation coefficient } \\
\text { MSBJ: Mean square between judges } \\
\text { SSBJ: Sum of square between judges } \\
\text { dfBJ: Degree of freedom between judges } \\
\text { MSBS: Mean square between judges } \\
\text { SSBS: Sum of square between judges } \\
\text { dfBS: Degree of freedom between judges } \\
\text { MSR: Mean square residual SSR: Sum of } \\
\text { square residual } \\
\text { dfres: Degree of freedom residual } \\
\text { SST: Total of sum of square between judges } \\
\text { Si: Relative values of expert i } \\
\text { Xj: Relative values for subject j } \\
\text { X.T:: Grand total of relative values for } \\
\text { subject j } \\
\text { k: Number of judges } \\
\text { n: Number of subjects }\end{array}$ \\
\hline
\end{tabular}

The different range of ICC values and the interpretation are summarized below: 
Table 19: Range of ICC Values

\begin{tabular}{|l|l|}
\hline \multicolumn{1}{|c|}{ ICC Value } & \multicolumn{1}{c|}{ Interpretation } \\
\hline$-1<$ ICC $<1$ & ICC Range \\
\hline ICC $=1$ & Absolute agreement between judges \\
\hline ICC $=-1$ & Absolute disagreement but is treated in the same ways as ICC $=0$ \\
\hline ICC $=0$ & Substantial difference between judgments on value of subjects \\
\hline $0<\mathrm{ICC}<1$ & $\begin{array}{l}\text { indicates a degree of agreement between judges and the higher the value, the greater } \\
\text { the level of agreement }\end{array}$ \\
\hline$-1<\mathrm{ICC}<0$ & $\begin{array}{l}\text { This range makes ICC open for different interpretation of the results and not a very } \\
\text { reliable coefficient for judgment }\end{array}$ \\
\hline
\end{tabular}

Additionally, the statistical F-test is used to measure ICC. Therefore, the F-test tests the null hypothesis at a certain level of confidence:

Ho: $\mathrm{ICC}=0$

If the ICC is not rejected, this means that there was absolute disagreement between experts. Therefore, there is no correlation. The F-value in an F-test can be calculated as the ratio of two sums of squares. In the case of HDM, the F-value can be estimated by:

$$
F=\frac{M S B S}{M S R}
$$

The levels of confidence $(\alpha)$ are usually with the values of $0.01,0.05,0.025$, or more. Based on these $\alpha$ levels, the critical $\mathrm{F}$ values are found in tables.

If $\mathrm{F}$ calculated $>\mathrm{F}$ critical, then Ho is rejected; therefore, there is no disagreement among the experts' judgments. The calculated $F$ is the value provided by the HDM software.

As Estep [237] explained, Iskin [89] used hierarchical clustering to examine disagreements between experts. By using the clustering, disagreements between experts or a group of experts can be identified. Acceptable disagreement is a value of 0.1 or less. 


\subsubsection{Sensitivity Analysis}

The initial condition that established the model can change due to many reasons. Therefore, it is important to measure the effects of these changes. Multi-criteria models, and more specifically, HDM, incorporate this analysis of the impact of potential changes. As Gibson [232] established, there are many methods to analyze potential changes known as a sensitivity analysis. HDM sensitive analysis is a method developed by Chen and Kocaoglu [247]. This method uses a mathematical deduction approach to analyze the changes, the effects, and the flexibility and robustness of the results. A sensitivity analysis could be done at any level or for any element [232]. Additionally, this method has been used as scenario analysis, such as Estep [237], who measured the impact on the rank due to changes in top-level perspectives in the model.

Sensitivity analysis can be used to consider changes in any level or any element of the HDM decision model. Due to possible changes and the respective analysis, it is possible to know and understand the effects of the decisions on the rank or order of the elements [232].

Sensitivity analysis can be used to establish how much the decision variables can change before changing the order of alternatives [235]. Abotah [235] summarized the explanation by Chen and Kocaoglu [247] in an HDM four-level model:

$$
C_{i}^{A-M}=\sum_{l=1}^{L} \sum_{k=1}^{k} C_{i}^{C-M} \cdot C_{k l}^{G-S} \cdot C_{i k}^{A-S}
$$

Where: 


\section{$\mathrm{A}_{\mathrm{i}}$ : Alternatives}

M: Mission

$C_{i}^{C-M}:$ Local contribution of the $\mathrm{L}^{\text {th }}$ criterion to the mission

$C_{k l}^{S-C}:$ Local contribution of the $\mathrm{k}^{\text {th }}$ sub-criterion to the $\mathrm{L}^{\text {th }}$ objective

$C_{i}^{A-M}:$ Overall contribution of $\mathrm{i}^{\text {th }}$ alternative to the mission

$C_{i k}^{A-S}:$ Local contribution of $\mathrm{i}^{\text {th }}$ alternative to the $\mathrm{K}^{\text {th }}$ sub-criterion

$C_{i l}^{A-C} \quad:$ Global contribution of $\mathrm{i}^{\text {th }}$ alternative to the $\mathrm{L}^{\text {th }}$ criteria

The calculation of the parameters allows for knowing the effects on the alternatives. At the same time, it is possible to establish the tolerance, which is defined as "the allowable range in which a contribution value can vary without changing the rank order of decision alternatives" [235].

If there is perturbation $P_{l *}^{o}$ in the criteria level (top level $C_{i}^{C}$ ), where,

$$
-C_{l *}^{C} \leq P_{l *}^{C} \leq 1-C_{l *}^{C}
$$

The original ranking of the alternatives $A_{i}$ and $A_{r+n}$ will not change if:

$$
\lambda \geq P_{i}^{C} \cdot \lambda^{C}
$$

Where:

$$
\lambda=C_{r}^{A}-C_{r+n}^{A}
$$

The feasibility condition is: 


$$
-C_{l *}^{C} \leq P_{l *}^{C} \leq 1-C_{l *}^{C}
$$

The ranking of alternatives will keep the same in the below equation if $n=1$ and $\mathrm{r}=1,2 \ldots . \mathrm{I}-1$.

$$
\lambda^{C}=C_{r+n, l *}^{A-C}-C_{r l *}^{A}-\sum_{l=1, l \neq l *}^{L} C_{r+n, l *}^{A-C} \cdot \frac{C_{l}^{C}}{\sum_{l=1, l \neq l *}^{L} C_{l}^{O}}+\sum_{l=1, l \neq l *}^{L} \frac{C_{r l}^{A-O}}{\sum_{l=1, l \neq l *}^{L} C_{l}^{O}}
$$

If only the first alternative is important to keep unchangeable, the $\mathrm{r}=1$ and $\mathrm{n}=1,2, \ldots, \mathrm{I}-1$

Allowance range of perturbations $C_{i}^{C}$ to keep the current ranking is:

$$
\left[\delta_{i-}^{C}, \delta C_{i+}^{O}\right]
$$

The sensitivity coefficient is calculated by:

$$
1 /\left|\delta_{i+}^{C}, \delta_{i-}^{C}\right|
$$




\section{CHAPTER 6: DEVELOPMENT OF THE RESEARCH MODEL}

\subsection{Expert Panel Formation}

The final number of experts, their characteristics, and the distribution through the stages of the research are shown below.

Table 20: Expert Panel Design

\begin{tabular}{|c|c|c|c|c|}
\hline $\begin{array}{c}\text { Panel } \\
\#\end{array}$ & $\begin{array}{l}\text { Research } \\
\text { Instrument }\end{array}$ & Step 1 & Step 2 & Size \\
\hline EP01 & RI1 & \multicolumn{2}{|c|}{ Criteria validation } & 18 participants \\
\hline EP02 & RI2 & \multicolumn{2}{|c|}{ Sub-criteria validation } & 30 participants \\
\hline EP1 & RI3 & \multicolumn{2}{|c|}{$\begin{array}{l}\text { Quantify the contribution of each criterion to the } \\
\text { mission. }\end{array}$} & 9 participants \\
\hline EP2 & RI4 & $\begin{array}{l}\text { Quantify the contribution } \\
\text { of technical sub-criteria. }\end{array}$ & $\begin{array}{l}\text { Evaluate the relative } \\
\text { contribution of } \\
\text { alternatives with respect } \\
\text { to the technical sub- } \\
\text { criteria }\end{array}$ & 7 participants \\
\hline EP2 & RI4 & $\begin{array}{l}\text { Quantify the contribution } \\
\text { of market sub-criteria. }\end{array}$ & $\begin{array}{l}\text { Evaluate the relative } \\
\text { contribution of } \\
\text { alternatives with respect } \\
\text { to the market sub-criteria. }\end{array}$ & 7 participants \\
\hline EP2 & RI4 & $\begin{array}{l}\text { Quantify the contribution } \\
\text { of organizational sub- } \\
\text { criteria. }\end{array}$ & $\begin{array}{l}\text { Evaluate the relative } \\
\text { contribution of } \\
\text { alternatives with respect } \\
\text { to the organizational sub- } \\
\text { criteria. }\end{array}$ & 8 participants \\
\hline EP2 & RI4 & $\begin{array}{l}\text { Quantify the contribution } \\
\text { of economic sub-criteria. }\end{array}$ & $\begin{array}{l}\text { Evaluate the relative } \\
\text { contribution of } \\
\text { alternatives with respect } \\
\text { to the economic sub- } \\
\text { criteria. }\end{array}$ & 7 participants \\
\hline EP2 & RI4 & $\begin{array}{l}\text { Quantify the contribution } \\
\text { of External/Regulation/ } \\
\text { Environmental. }\end{array}$ & $\begin{array}{l}\text { Evaluate the relative } \\
\text { contribution of } \\
\text { alternatives with respect } \\
\text { to the } \\
\text { External/Regulation/ } \\
\text { Environmental. }\end{array}$ & 8 participants \\
\hline
\end{tabular}


Table 21: Distribution of Experts for Validation and Quantification of the HDM

\begin{tabular}{|c|c|c|c|c|c|c|c|c|c|c|c|c|}
\hline \multirow[b]{3}{*}{ Expert ID } & \multicolumn{6}{|c|}{ Model Validation } & \multicolumn{6}{|c|}{ Model Quantification } \\
\hline & \multirow[b]{2}{*}{ Criteria } & \multicolumn{5}{|c|}{ Sub-criteria } & \multirow[b]{2}{*}{ Criteria } & \multicolumn{5}{|c|}{ Sub-criteria } \\
\hline & & 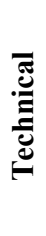 & 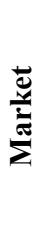 & 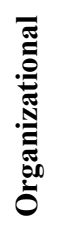 & 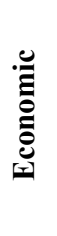 & 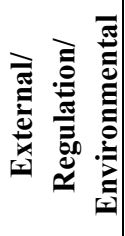 & & 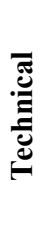 & 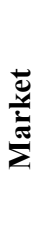 & 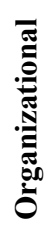 & 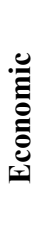 & 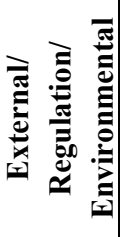 \\
\hline Expert 1 & & $\mathrm{X}$ & & $\mathrm{X}$ & $\mathrm{X}$ & & & & $\mathrm{X}$ & $\mathrm{X}$ & & \\
\hline Expert 2 & & $\mathrm{X}$ & $\mathrm{X}$ & $\mathrm{X}$ & & & & & $\mathrm{X}$ & & $\mathrm{X}$ & \\
\hline Expert 3 & $\mathrm{X}$ & $\mathrm{X}$ & & $\mathrm{X}$ & & $\mathrm{X}$ & & & & & & \\
\hline Expert 4 & $\mathrm{X}$ & $\mathrm{X}$ & $\mathrm{X}$ & & $\mathrm{X}$ & & $\mathrm{X}$ & $\mathrm{X}$ & & & & \\
\hline Expert 5 & $\mathrm{X}$ & $\mathrm{X}$ & & & & $\mathrm{X}$ & & $\mathrm{X}$ & & & & \\
\hline Expert 6 & $\mathrm{X}$ & & $\mathrm{X}$ & $\mathrm{X}$ & $\mathrm{X}$ & & & & & & & \\
\hline Expert 7 & $\mathrm{X}$ & & & & & & $\mathrm{X}$ & & & & $\mathrm{X}$ & \\
\hline Expert 8 & & & & & & & & & $\mathrm{X}$ & & $\mathrm{X}$ & \\
\hline Expert 9 & & & & & & & & & $\mathrm{X}$ & & $\mathrm{X}$ & \\
\hline Expert 10 & $\mathrm{X}$ & & $\mathrm{X}$ & & $\mathrm{X}$ & $\mathrm{X}$ & $\mathrm{X}$ & & & & & $\mathrm{X}$ \\
\hline Expert 11 & & $\mathrm{X}$ & $\mathrm{X}$ & & $\mathrm{X}$ & $\mathrm{X}$ & & & $\mathrm{X}$ & & & $\mathrm{X}$ \\
\hline Expert 12 & $\mathrm{X}$ & $X$ & & $\mathrm{X}$ & & & $\mathrm{X}$ & & & & & \\
\hline Expert 13 & $\mathrm{X}$ & $\mathrm{X}$ & $\mathrm{X}$ & & & $\mathrm{X}$ & $\mathrm{X}$ & & & & & $\mathrm{X}$ \\
\hline Expert 14 & & & & & & & & & $\mathrm{X}$ & & & $\mathrm{X}$ \\
\hline Expert 15 & & $\mathrm{X}$ & & $\mathrm{X}$ & $\mathrm{X}$ & $\mathrm{X}$ & & $\mathrm{X}$ & & & $\mathrm{X}$ & \\
\hline Expert 16 & & $\mathrm{X}$ & & $\mathrm{X}$ & & & & $\mathrm{X}$ & & $\mathrm{X}$ & & \\
\hline Expert 17 & $\mathrm{X}$ & $\mathrm{X}$ & $\mathrm{X}$ & & $\mathrm{X}$ & $\mathrm{X}$ & & & & & & \\
\hline Expert 18 & & & & & & & & & $X$ & & & \\
\hline Expert 19 & $\mathrm{X}$ & & $\mathrm{X}$ & $\mathrm{X}$ & $\mathrm{X}$ & $\mathrm{X}$ & $\mathrm{X}$ & & & & & $\mathrm{X}$ \\
\hline Expert 20 & & $X$ & & $X$ & $\mathrm{X}$ & $\mathrm{X}$ & & & & & & \\
\hline Expert 21 & $\mathrm{X}$ & & & & & & & & & $\mathrm{X}$ & $\mathrm{X}$ & \\
\hline Expert 22 & $\mathrm{X}$ & $\mathrm{X}$ & $\mathrm{X}$ & & $\mathrm{X}$ & $\mathrm{X}$ & & & & & & \\
\hline Expert 23 & $\mathrm{X}$ & & $\mathrm{X}$ & $\mathrm{X}$ & $\mathrm{X}$ & $\mathrm{X}$ & $\mathrm{X}$ & & & $\mathrm{X}$ & & \\
\hline Expert 24 & & & $\mathrm{X}$ & $\mathrm{X}$ & $\mathrm{X}$ & $\mathrm{X}$ & & & & & & \\
\hline Expert 25 & $\mathrm{X}$ & $\mathrm{X}$ & $\mathrm{X}$ & & $\mathrm{X}$ & $\mathrm{X}$ & $\mathrm{X}$ & $\mathrm{X}$ & & $\mathrm{X}$ & & $\mathrm{X}$ \\
\hline Expert 26 & & & & & & & $X$ & & & & $\mathrm{X}$ & \\
\hline Expert 27 & $\mathrm{X}$ & $\mathrm{X}$ & & $\mathrm{X}$ & & $\mathrm{X}$ & & $\mathrm{X}$ & & $\mathrm{X}$ & & \\
\hline Expert 28 & & $X$ & $\mathrm{X}$ & & & $\mathrm{X}$ & & $\mathrm{X}$ & & $\mathrm{X}$ & & \\
\hline Expert 29 & $\mathrm{X}$ & & & & & & & & & & & \\
\hline Expert 30 & & $\mathrm{X}$ & $\mathrm{X}$ & & & $\mathrm{X}$ & & & & & & \\
\hline Expert 31 & $\mathrm{X}$ & & & & & & & & & & & \\
\hline Expert 32 & $\mathrm{X}$ & & $\mathrm{X}$ & & $X$ & $\mathrm{X}$ & & & & & & \\
\hline $\begin{array}{l}\text { Total Number } \\
\text { of Experts }\end{array}$ & 18 & 17 & 15 & 12 & 14 & 17 & 9 & 7 & 7 & 7 & 7 & 6 \\
\hline
\end{tabular}


Experts were selected according to the type of organization to eliminate any bias and capture the information from perspectives. These organizations are from academia and form the industrial field. At the same time, experts from private establishments, RTOs, regional organizations, and National Labs in the United States were selected.

Table 22: Experts by Type of Organization

\begin{tabular}{|l|c|}
\hline & Type of Organization \\
\hline Academia & 12 \\
\hline BPA & 9 \\
\hline Regulated Utility & 4 \\
\hline Lab & 3 \\
\hline Private Transmission Analyst & 2 \\
\hline Regional Organization & 1 \\
\hline RTO & 1 \\
\hline Total & $\mathbf{3 2}$ \\
\hline
\end{tabular}

The present model, as shown above, is based on theoretical aspects and represents an opportunity to be generalized for its use in different regions around the world. Therefore, the experts were selected from different parts of the world, such as Spain, the Netherland, and Sweden. These countries were selected since they have similar energy and regulation markets.

Table 23: Experts by Country

\begin{tabular}{|l|c|}
\hline & Country \\
\hline USA & 27 \\
\hline Spain & 3 \\
\hline Netherland & 1 \\
\hline Sweden & 1 \\
\hline Grand Total & $\mathbf{3 2}$ \\
\hline
\end{tabular}




\subsection{Results and Data Analysis - Research Application}

\subsection{Step 1: Hierarchical Model Development}

The model development was conducted based on the literature review. Based on this literature review, a preliminary assessment model was created. The comprehensive literature review was done in the area of power transmission $\mathrm{R} \& \mathrm{D}$ projects. The variables were categorized according to the criteria and sub-criteria (technical, market, economic, organizational, and environmental/regulation).

The established objective is to evaluate multi-perspective $R \& D$ for project selection in the power sector. Five different criteria and 18 sub-criteria have been identified and shown in the HDM model.

\section{Conceptual HDM}

The objective is to evaluate multi-perspective $R \& D$ for project selection in the power sector. The HDM is: 


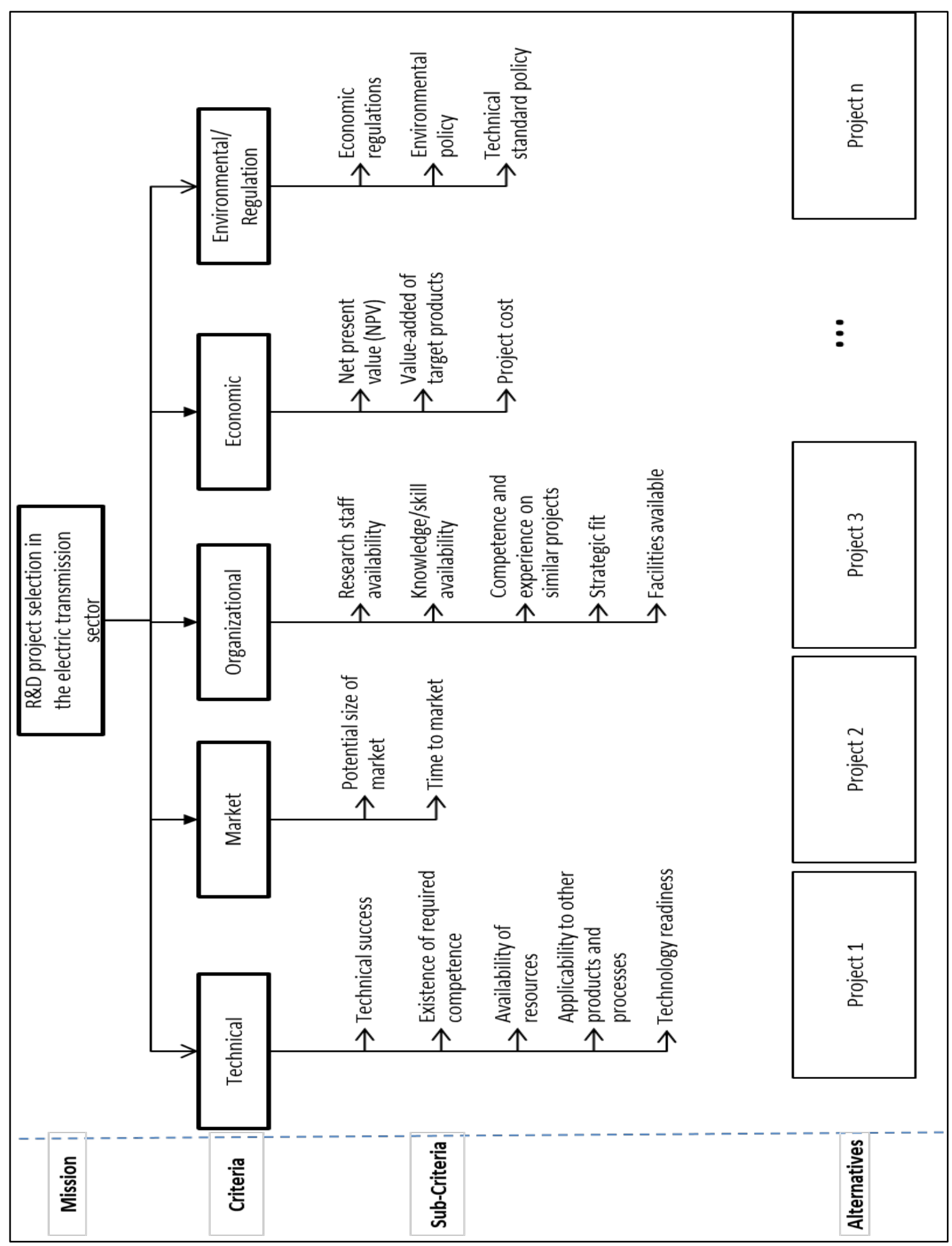

Figure 18: Hierarchical Model Development 
Table 24: Description of Criteria - Level 2

\begin{tabular}{|c|c|c|}
\hline Criteria & Description of Criteria - Level 2 & Reference \\
\hline Technical & $\begin{array}{l}\text { This criterion is related to the technological context, } \\
\text { which relates to how technology characteristics } \\
\text { themselves can influence the R\&D projects. }\end{array}$ & $\begin{array}{l}\text { [77], [78], [5], [79], [35], } \\
{[80],[81],[212],[214],} \\
{[227],[114],[169],[179],} \\
{[189]}\end{array}$ \\
\hline Market & $\begin{array}{l}\text { These attributes scrutinize the various market limits } \\
\text { associated with the development of new technologies } \\
\text { through R\&D projects. It is directly associated with the } \\
\text { side of the size of demand. }\end{array}$ & $\begin{array}{l}\text { [77], [78], [5], [79], [35], } \\
{[80],[81],[214],[227],} \\
{[114],[169],[179],[189]}\end{array}$ \\
\hline Organizational & $\begin{array}{l}\text { The organizational context is related to the characteristics } \\
\text { of the organization. It looks at the structure and processes } \\
\text { of an organization that constrains or facilitates the R\&D } \\
\text { projects. }\end{array}$ & $\begin{array}{l}\text { [78], [5], [79], [214], [212], } \\
{[215],[214],[211]}\end{array}$ \\
\hline Economic & Financial characteristics of the $R \& D$ projects. & $\begin{array}{l}{[78],[35],[80],[82],[97],} \\
{[227],[114],[169],[179],} \\
{[189],[97],[128],[226],} \\
{[126]}\end{array}$ \\
\hline Environmental & $\begin{array}{l}\text { These attributes consider external factors that influence } \\
\text { R\&D projects, considering mainly environmental and } \\
\text { governmental factors. Additionally, technical standards } \\
\text { and stakeholders' voices are considered. }\end{array}$ & $\begin{array}{l}\text { [77], [5], [80], [227], [114], } \\
{[169],[179],[189],[97],} \\
{[128],[226],[126]}\end{array}$ \\
\hline
\end{tabular}

Table 25: Description of Sub-Criteria - Level 3

\begin{tabular}{|c|l|l|c|}
\hline Criteria & \multicolumn{1}{|c|}{ Sub-Criteria } & \multicolumn{1}{|c|}{ Description of Sub-Criteria - Level 3 } & References \\
\hline \multirow{5}{*}{ Technical } & Technical success & $\begin{array}{l}\text { Opportunity (probability, prospect) of } \\
\text { success for thechnology. This sub- } \\
\text { criterium considers implicitly technical } \\
\text { risk. }\end{array}$ & $\begin{array}{c}\text { [79], [81], [82], } \\
{[10],[212],} \\
{[211],[214]}\end{array}$ \\
\cline { 2 - 5 } & $\begin{array}{l}\text { Existence of } \\
\text { required competence }\end{array}$ & $\begin{array}{l}\text { The ability, knowledge, and skills to to } \\
\text { perform and develop the R\&D project } \\
\text { consistently over time. }\end{array}$ & $\begin{array}{c}{[77],[79],[81],} \\
{[214],[209]}\end{array}$ \\
\cline { 2 - 5 } & $\begin{array}{l}\text { Availability of } \\
\text { resources }\end{array}$ & $\begin{array}{l}\text { Availability of technical resources, } \\
\text { technical support, and equipment support. }\end{array}$ & $\begin{array}{c}{[77],[81],[82],} \\
{[10],[212],[211]}\end{array}$ \\
\cline { 2 - 5 } & $\begin{array}{l}\text { Applicability to } \\
\text { other products and } \\
\text { processes }\end{array}$ & $\begin{array}{l}\text { Opportunity to apply the new technology } \\
\text { to other products or processes different } \\
\text { from the original objectives. }\end{array}$ & {$[77],[97]$} \\
\cline { 2 - 5 } & $\begin{array}{l}\text { Technology Readiness Levels (TRL) are a } \\
\text { method of estimating technology maturity } \\
\text { of Critical Technology Elements (CTE) of } \\
\text { a program during the acquisition process. }\end{array}$ & $\begin{array}{c}{[35],[81],[212],} \\
{[209]}\end{array}$ \\
\hline
\end{tabular}




\begin{tabular}{|c|c|c|c|}
\hline Criteria & Sub-Criteria & Description of Sub-Criteria - Level 3 & References \\
\hline \multirow{5}{*}{ Market } & $\begin{array}{l}\text { Potential size of } \\
\text { market }\end{array}$ & $\begin{array}{l}\text { The market size is typically defined by the } \\
\text { number of units sold (energy level) in the } \\
\text { market in a given year. This is used as an } \\
\text { input to determine the baseline energy } \\
\text { consumption (using the average unit } \\
\text { energy consumption; it is the actual market } \\
\text { energy consumption - BPA Firm energy). }\end{array}$ & $\begin{array}{c}\text { [77], [5], [79], } \\
{[35],[81],[10],} \\
{[84],[212],} \\
{[214],[213],} \\
{[126],[212],} \\
{[215],[214],} \\
{[211]} \\
\end{array}$ \\
\hline & Time to market & $\begin{array}{l}\text { It is the length of time that development } \\
\text { takes a product being conceived until its } \\
\text { being available for sale or its use. }\end{array}$ & $\begin{array}{l}{[79],[81],[82],} \\
{[10],[211],[214]}\end{array}$ \\
\hline & $\begin{array}{l}\text { Additional (variety) } \\
\text { applications opened }\end{array}$ & $\begin{array}{l}\text { Additional technologies and applications } \\
\text { that can be derived from the results of the } \\
\text { R\&D project }\end{array}$ & {$[5],[79],[82]$} \\
\hline & Market risk & $\begin{array}{l}\text { Stability of the market, specifically } \\
\text { referred to the variations of the size of the } \\
\text { market as defined above. }\end{array}$ & $\begin{array}{c}{[5],[79],[35],} \\
{[77]}\end{array}$ \\
\hline & $\begin{array}{l}\text { Load and Power } \\
\text { System Planning }\end{array}$ & $\begin{array}{l}\text { How the power system will grow over a } \\
\text { period of time. The load forecasting is } \\
\text { based on facts, assumptions, and logic } \\
\text { judgments. }\end{array}$ & $\begin{array}{l}\text { Added by SME - } \\
\text { RI02 }\end{array}$ \\
\hline \multirow{5}{*}{ Organizational } & $\begin{array}{l}\text { Research staff } \\
\text { availability }\end{array}$ & $\begin{array}{l}\text { Available technical staff for research and } \\
\text { development of a specific project. }\end{array}$ & $\begin{array}{c}{[212],[211],} \\
{[214],[97],[126]}\end{array}$ \\
\hline & $\begin{array}{l}\text { Knowledge/skill } \\
\text { availability }\end{array}$ & $\begin{array}{l}\text { The capability of the research team such as } \\
\text { the competence (progressive and } \\
\text { diversified training and experience) of the } \\
\text { project leader and technical staff. }\end{array}$ & [77], [97], [126] \\
\hline & $\begin{array}{l}\text { Competence and } \\
\text { experience on } \\
\text { similar projects }\end{array}$ & $\begin{array}{l}\text { Ability to perform the new project based } \\
\text { on the experience in similar or previous } \\
\text { projects. }\end{array}$ & {$[77],[248]$} \\
\hline & Strategic fit & $\begin{array}{l}\text { Appropriateness of the project concerning } \\
\text { an organization's overall objectives. }\end{array}$ & $\begin{array}{c}\text { [77], [79], [214], } \\
{[126],[209],} \\
{[227],[114],} \\
{[97],[128],} \\
{[226],[126],} \\
{[212],[215],} \\
{[214],[211]} \\
\end{array}$ \\
\hline & Available facilities & $\begin{array}{l}\text { Buildings or equipment for developing } \\
\text { the project. }\end{array}$ & {$[211]$} \\
\hline \multirow{4}{*}{ Economic } & $\begin{array}{l}\text { Net present value } \\
(\mathrm{NPV}) .\end{array}$ & $\begin{array}{l}\text { The present amount invested and future } \\
\text { cash amount discounted by a specified rate } \\
\text { of return. }\end{array}$ & [79], [12], [214] \\
\hline & $\begin{array}{l}\text { Value-added of } \\
\text { target products }\end{array}$ & $\begin{array}{l}\text { Economic benefits of developing the } \\
\text { product. }\end{array}$ & $\begin{array}{c}78],[82],[97] \\
{[128],[226]} \\
{[126]}\end{array}$ \\
\hline & Project cost & $\begin{array}{l}\text { Total expending in the project, including } \\
\text { capital and operation costs. }\end{array}$ & $\begin{array}{c}{[10],[84],[211],} \\
{[213],[126]}\end{array}$ \\
\hline & Economic risk & $\begin{array}{l}\text { The associated risk with financial and } \\
\text { economic factors on the project, such as } \\
\text { costs or economic benefits. }\end{array}$ & $\begin{array}{l}\text { Added by SME - } \\
\text { RI02 }\end{array}$ \\
\hline
\end{tabular}




\begin{tabular}{|c|c|c|c|}
\hline Criteria & Sub-Criteria & Description of Sub-Criteria - Level 3 & References \\
\hline \multirow{5}{*}{$\begin{array}{l}\text { Level } 3 \\
\text { (Sub-Criteria) } \\
\text { External/ } \\
\text { Regulation/ } \\
\text { Environmental }\end{array}$} & $\begin{array}{l}\text { Economic } \\
\text { regulations }\end{array}$ & $\begin{array}{l}\text { Legislative measures and government } \\
\text { regulations to affect economic outcomes. }\end{array}$ & $\begin{array}{c}5],[79],[10], \\
{[214],[213],} \\
{[227],} \\
{[114][209],} \\
{[169],[179],} \\
{[189],}\end{array}$ \\
\hline & $\begin{array}{l}\text { Environmental } \\
\text { policy }\end{array}$ & $\begin{array}{l}\text { The relationship between the R\&D project } \\
\text { and the commitment of an organization to } \\
\text { the laws, regulations, and other policy } \\
\text { mechanisms regarding technical, } \\
\text { economic, and environmental issues. }\end{array}$ & $\begin{array}{c}\text { [77], [5], [79], } \\
{[82],[10],[214],} \\
{[169],[179],} \\
{[189]}\end{array}$ \\
\hline & $\begin{array}{l}\text { Reliability, } \\
\text { resilience, state } \\
\text { Awareness technical } \\
\text { standards }\end{array}$ & $\begin{array}{l}\text { It is an established norm or requirement } \\
\text { regarding technical systems to ensure the } \\
\text { reliability of the bulk power system. }\end{array}$ & $\begin{array}{c}{[5],[82],[213],} \\
{[97],[209]}\end{array}$ \\
\hline & $\begin{array}{l}\text { Power Quality } \\
\text { standards }\end{array}$ & $\begin{array}{l}\text { Standards related to reducing the } \\
\text { disturbances of covering areas of voltage, } \\
\text { harmonic distortion, flicker, disturbances, } \\
\text { frequency. }\end{array}$ & $\begin{array}{l}\text { Added by SME - } \\
\text { RI02 }\end{array}$ \\
\hline & $\begin{array}{l}\text { Acceptance of } \\
\text { stakeholders }\end{array}$ & $\begin{array}{l}\text { Stakeholders' perception of the project } \\
\text { and/or new technology. }\end{array}$ & $\begin{array}{l}\text { Added by SME - } \\
\text { RI02 }\end{array}$ \\
\hline
\end{tabular}

\subsection{Step 2: Model Development Update based on Identification of Supporting}

\section{Theories}

Organizations that present characteristics of a natural monopoly are often regulated.

A natural monopoly appears when only one firm can produce at a lower cost than many companies. In this case, the production can be done by only one firm, because competition is not socially desirable [249]. However, a natural monopoly is regulated in order to increase the social welfare. Regulated organizations invest to maximize their profits; these organizations will produce lower quantities at high prices; therefore, not socially desirable. In the electrical utility market, regulations are focused on three main aspects: energy price, quality of the product, and the quantity to be generated, transmitted, and distributed. 
Consequently, the selection of R\&D projects will be both defined by the strategy of the organization and affected by regulations.

Theories about investment in R\&D in regulated organizations are different from organizations operating in competitive markets. The first theory is associated with "natural monopoly," which requires government intervention. The regulated aspects are price, quantity, and quality of the product. Two theories explain the regulation due to the "market failure.” These are Public Interest Theory and Interest Group Theory [249]. The four main aspects regulated are price, quantity, quality, and environment.

$R \& D$ projects are associated with economic regulation, such as price and financial aspects. At the same time, technical aspects determine what to invest and how much. Moreover, risks are associated with the financial and technical aspects. The quality of the product can be explained by the increasing cost of high quality required and the "natural behavior" of organizations selecting the lower costs regarding quality, and more so if this connected with monopoly or natural monopoly markets. Therefore, these are the main aspects to be taken into account: quantity, price (financial) quality, regulation, environment, and risk.

The decision to select $R \& D$ projects is directly related to investment, innovation, market models, and market conditions. In the case of utilities, the environment is related to natural monopoly conditions and the "necessity" of the government intervention to protect the customers since the products are considered essential services and are provided only for one firm that has power over its customers. In natural monopolies, the regulation allows incentive organizations to produce the levels of outputs and prices that are socially 
optimum. The possible alternatives to regulate are price discrimination, Peak-Load Pricing, Price-Cap Regulation, Public Ownership, and others. Therefore, the criteria for evaluating $R \& D$ projects for regulated organizations include the criteria for non-profit organizations; however, the non-profit criteria exclude market and risk criteria.

The criteria need to incorporate these aspects and certain or specific conditions of regulations. This condition cannot be treated the same as in perfect market competition, in which the decision of the price, quantity, and innovation is socially efficient. The government intervention will modify the strategy of the organizations and decide the R\&D investments and will choose the $R \& D$ projects according to all the criteria associated with the innovation, price, quantity, market, and government requirements.

Environmental regulation is based on negative externalities. Additionally, the Economics of Quality can explain that there is a minimum level of quality at the lowest cost. The quality and continuity of the service need to be guaranteed; however, the quality of service needs to be high, which is related to a high cost.

Innovation can be based on Schumpeterian principles. The continuous innovation makes that Long Average Cost have a structural change; however, the changes in prices or rates are not as fast as the differences in costs and demand. Therefore, this will depend on legal and regulatory and political dimensions. The adjustments of the decisions of the organizations (strategy) depend on the criteria listed, as well as the dynamic of the market conditions [250].

- The main theories that explain R\&D investments are the following: 
- Market Structure (Natural monopoly theory and Economics of quality)

- Regulation (Public Interest Theory and Interest Group Theory)

- Innovation (Schumpeterian innovation and Dynamic Natural Monopolist)

- Environment (Pigovian tax)

Four main aspects are regulated: price, quantity, quality, and environment. R\&D projects are associated with economic regulation, such as price and financial aspects. At the same time, technical aspects determine what to invest and how much. Moreover, risks are associated with the financial and technical aspects. 


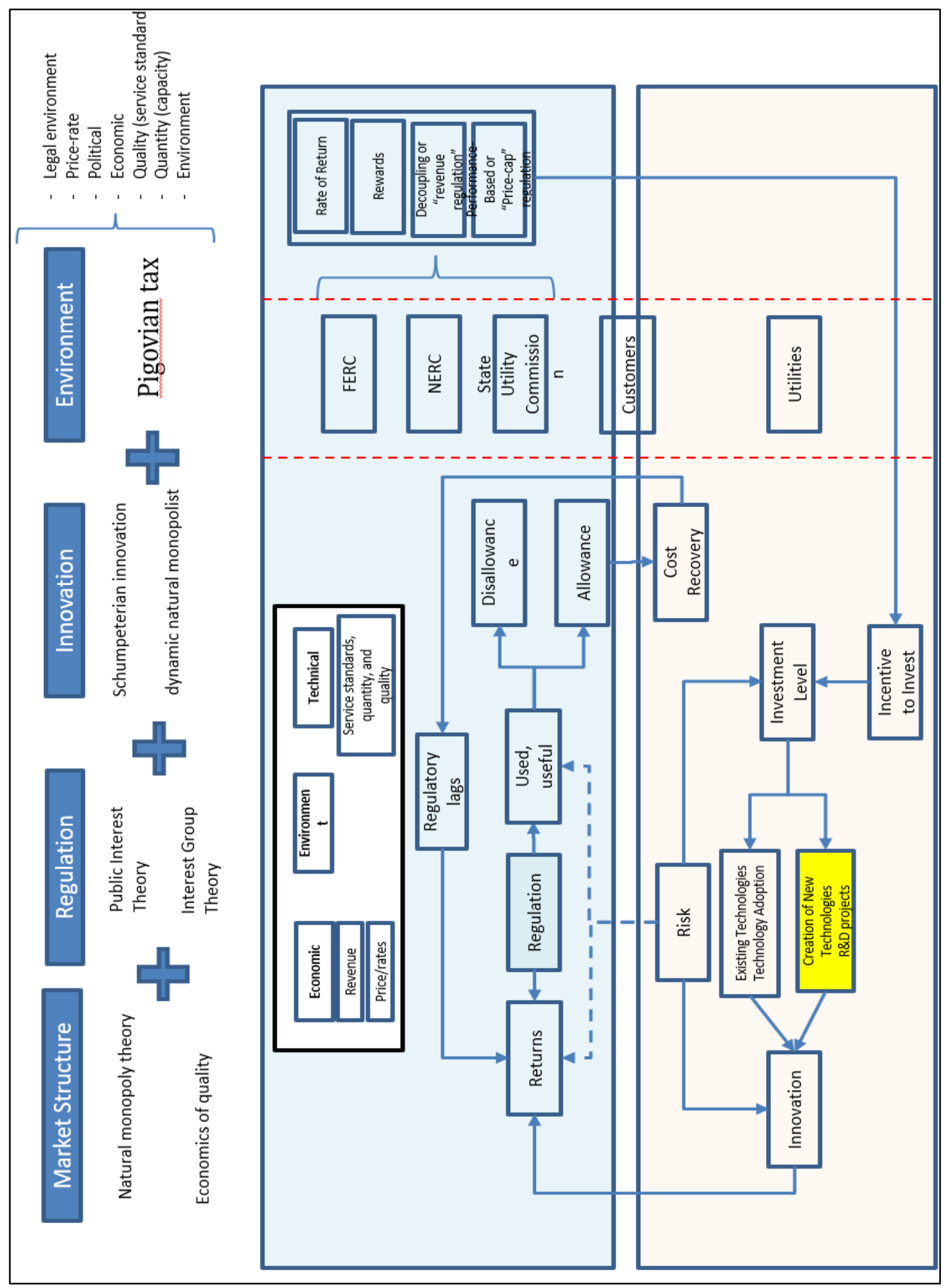

Figure 19: Integrating elements from Theoretical Models - Supporting Theories - Step 1 
Based on the identified theories, the criteria and sub-criteria identified in stage 2 were evaluated. Therefore, the criteria identified in the literature review were confirmed (criteria are directly associated with theoretical aspects), while the number of sub-criteria increases from 18 to 22. See the figure below.

All the criteria have been taken into account. Since regulated monopolies and projects, in general, are differentiated in the regulatory factors, the Technical, Market, Organizational, and Economic criteria correspond to both cases. The Environmental /Regulation contains all the factors associated with regulated organizations. Risk has been incorporated in the three main areas: Technical risk, market risk, and economic risk. Technical risk is intrinsically defined in the technical success sub-criterion.

Market risk is associated with changes in the levels of demand, these days a very sensitive issue, due to solar power or distributed generation. Economic risk is associated with monetary losses or changes in the economy. 


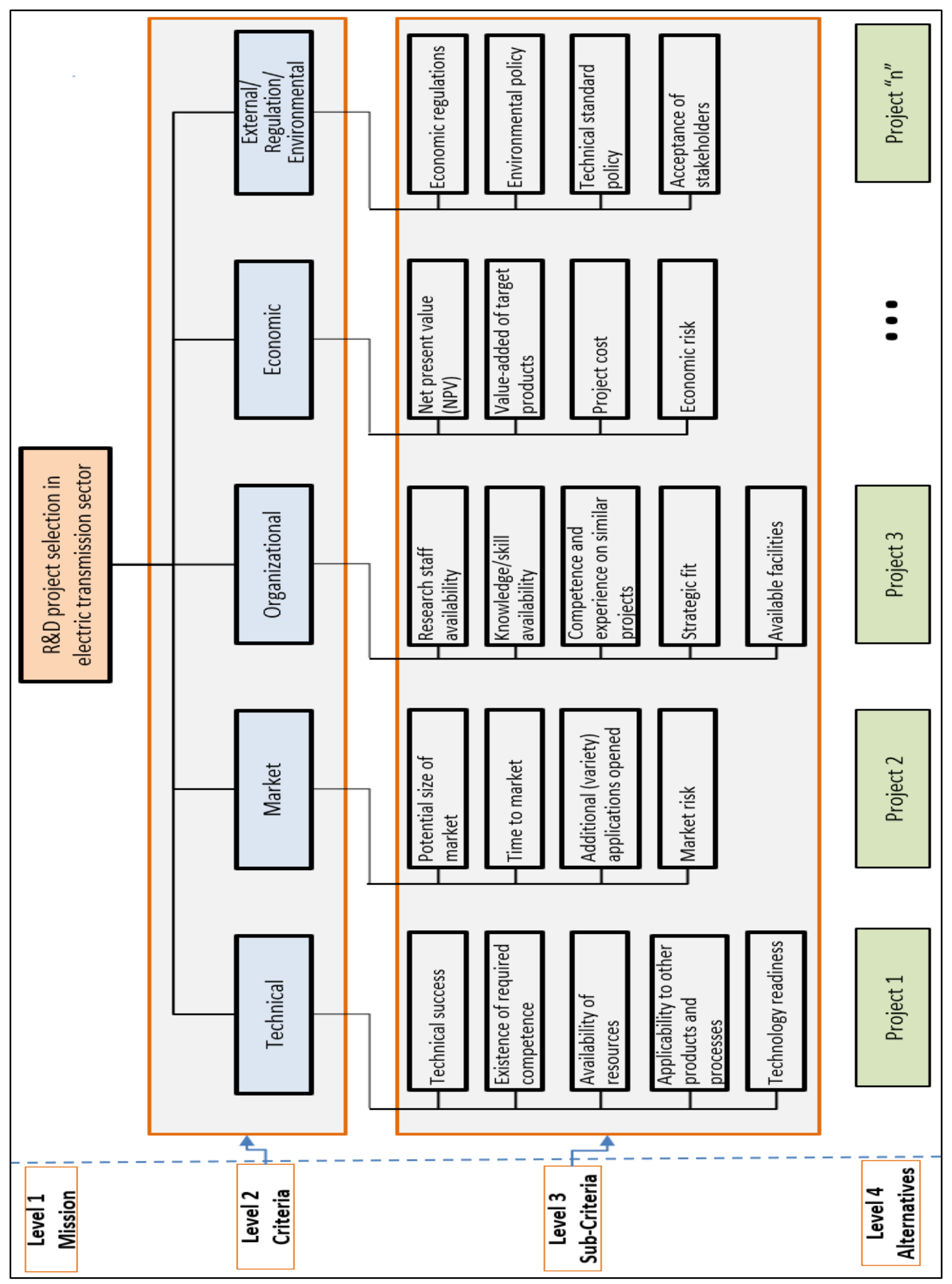

Figure 20: HDM Based on Literature Review and Theories 


\section{CHAPTER 7: RESULTS OF MODEL QUANTIFICATION}

\subsection{Content Validation}

Expert panels EP01 and EP02 consisted of 18 and 30 participants, respectively. Expert panels were formed based on their knowledge of energy, technology management, and previous experience working on $R \& D$ project planning in the electrical sector to get more consistent and logical results.

The panels were asked to comment on the model structure and content. The assessment tool was intended to capture their judgment about the criteria and sub-criteria and identify those that might have gone undetected during the literature review. A 2/3 majority criterion was necessary to keep the element. They were asked if the proposed criteria and sub-criteria were appropriate for evaluating $\mathrm{R} \& \mathrm{D}$ projects in a transmission power utility.

In addition to asking expert panels EP01 and EP02 to identify criteria and subcriteria, the experts were asked to comment on the model content. There were 18 participants in expert panel EP01 and 30 experts in panel EP02. Criteria and sub-criteria identified from literature research were presented to the experts. Experts were asked if the proposed criteria and sub-criteria were appropriate for R\&D project selection in the electric transmission sector and if there were other elements that should be excluded or added. The experts had the option to comment on other attributes that were not presented. 
The diagram below represents the proposed initial HDM model. This model was provided to expert panels EP01 and EP02 to evaluate using the research instruments RI1 and RI2.

\subsubsection{Criteria Validation}

Expert panel EP1 focused on validating the criteria. Content validity instrument RI01 was sent to Experts. A total of 18 experts provided input. As a result, all criteria were accepted and included in the final model. The table below shows a summary of the experts' responses.

Table 26: Criteria Validation - Experts' Responses

\begin{tabular}{|c|c|c|c|c|c|c|c|c|}
\hline & Sub-criteria & & & & No & Total & $\begin{array}{c}\text { Ratio } \\
\text { (Yes/Total) }\end{array}$ & Decision \\
\hline 1 & Technical & 18 & $100.00 \%$ & 0 & $0.00 \%$ & 18 & $100.00 \%$ & Included \\
\hline 2 & Market & 15 & $83.33 \%$ & 3 & $16.67 \%$ & 18 & $83.33 \%$ & Included \\
\hline 3 & Organizational & 15 & $83.33 \%$ & 3 & $16.67 \%$ & 18 & $83.33 \%$ & Included \\
\hline 4 & Economic & 17 & $94.44 \%$ & 1 & $5.56 \%$ & 18 & $94.44 \%$ & Included \\
\hline 5 & $\begin{array}{l}\text { External/ Regulation/ } \\
\text { Environmental }\end{array}$ & 16 & $88.89 \%$ & 2 & $11.11 \%$ & 18 & $88.89 \%$ & Included \\
\hline
\end{tabular}

Number of Experts who Agreed to Include the Criteria in the Framework

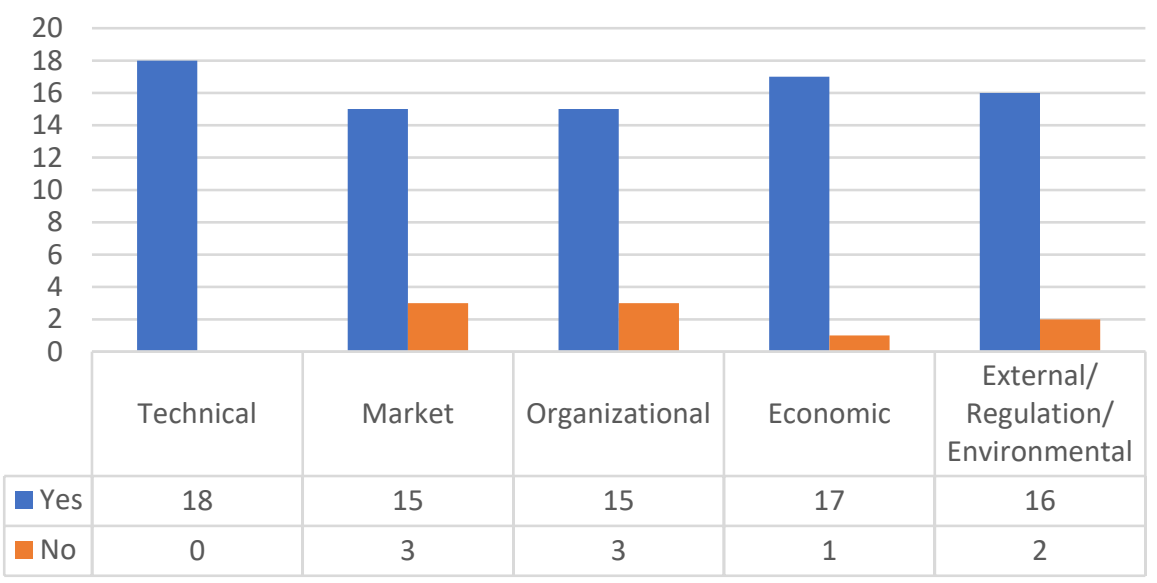

Figure 21: Criteria Validation - Experts' Responses 


\subsubsection{Sub-criteria Validation}

\section{Technical Criterion - Sub-criteria Validation}

Expert panel EP02 focused on validating the Technical sub-criteria in satisfying the Technical criterion. This panel EP02, conformed by 17 experts, validated the content of Technical criteria using the research instrument RI2. As a result, all Technical sub-criteria were accepted and included in the final model.

Table 27: Technical Criterion - Sub-Criteria Validation - Experts' Responses

Technical Criterion

\begin{tabular}{|c|l|c|c|c|c|c|c|c|}
\hline \multicolumn{1}{|c|}{ Sub-criteria } & \multicolumn{2}{|c|}{ Yes } & \multicolumn{2}{c|}{ No } & Total & $\begin{array}{c}\text { Ratio } \\
\text { (Yes/Total) }\end{array}$ & Decision \\
\hline 1 & Technical success & 16 & $94.12 \%$ & 1 & $5.88 \%$ & 17 & $94.12 \%$ & Included \\
\hline 2 & $\begin{array}{l}\text { Existence of required } \\
\text { competence }\end{array}$ & 14 & $82.35 \%$ & 3 & $17.65 \%$ & 17 & $82.35 \%$ & Included \\
\hline 3 & Availability of resources & 17 & $100.00 \%$ & 0 & $0.00 \%$ & 17 & $100.00 \%$ & Included \\
\hline 4 & $\begin{array}{l}\text { Applicability to other } \\
\text { products and processes }\end{array}$ & 12 & $70.59 \%$ & 5 & $29.41 \%$ & 17 & $70.59 \%$ & Included \\
\hline 5 & Technology readiness & 15 & $88.24 \%$ & 2 & $11.76 \%$ & 17 & $88.24 \%$ & Included \\
\hline
\end{tabular}

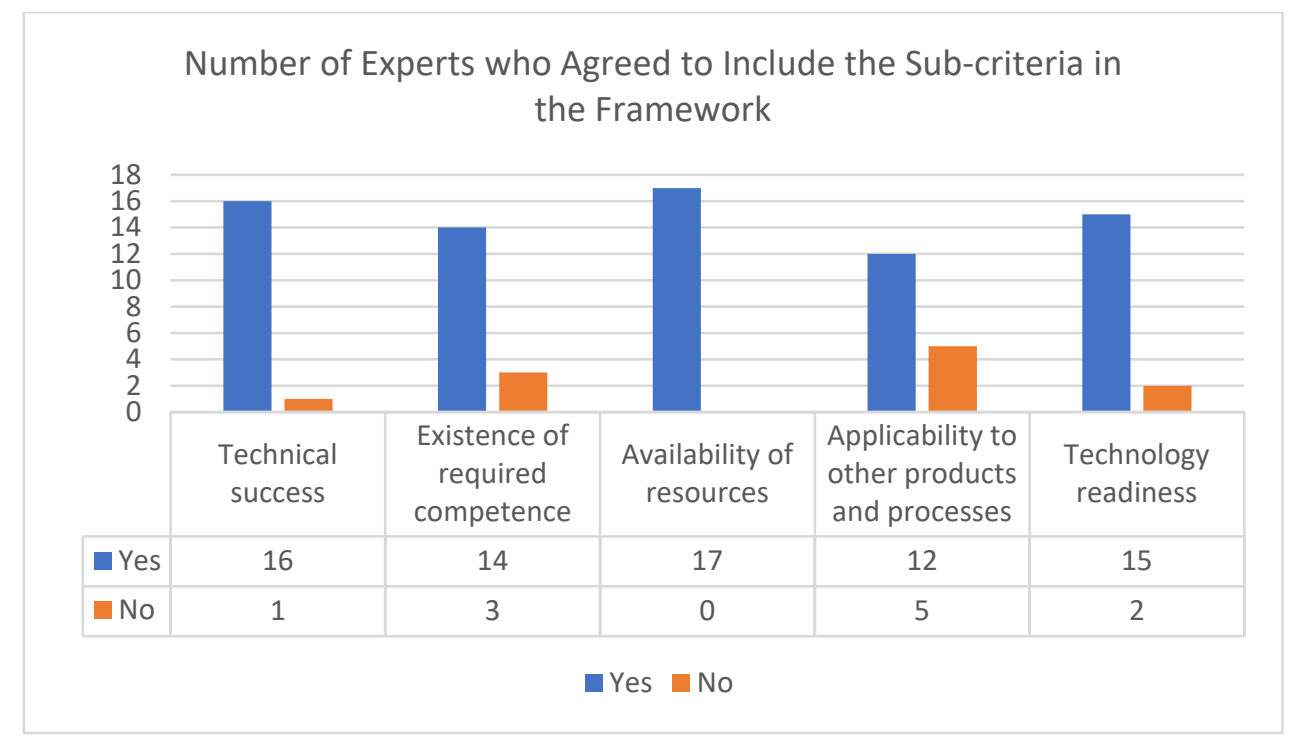

Figure 22: Technical Criterion - Sub-Criteria Validation - Experts' Responses 


\section{Market Criterion - Sub-criteria Validation}

Expert panel EP02 focused on validating the Market sub-criteria in satisfying the Market criterion. Content validity instrument RI02 was sent to the expert panel EP02. A total of 15 experts provided input. As a result, all Market sub-criteria were accepted and included in the final model.

Table 28: Market Criterion - Sub-Criteria Validation - Experts' Responses

Market Criterion

\begin{tabular}{|l|l|c|c|c|c|c|c|l|}
\hline \multicolumn{1}{|c|}{ Sub-criteria } & \multicolumn{2}{|c|}{ Yes } & \multicolumn{2}{c|}{ No } & Total & $\begin{array}{c}\text { Ratio } \\
\text { (Yes/Total) }\end{array}$ & Decision \\
\hline 1 & Potential size of market & 12 & $80.00 \%$ & 3 & $20.00 \%$ & 15 & $80.00 \%$ & Included \\
\hline 2 & Time to market & 15 & $100.00 \%$ & 0 & $0.00 \%$ & 15 & $100.00 \%$ & Included \\
\hline 3 & $\begin{array}{l}\text { Additional (variety) } \\
\text { applications opened }\end{array}$ & 12 & $80.00 \%$ & 3 & $20.00 \%$ & 15 & $80.00 \%$ & Included \\
\hline 4 & Market risk & 13 & $86.67 \%$ & 2 & $13.33 \%$ & 15 & $86.67 \%$ & Included \\
\hline 5 & $\begin{array}{l}\text { Load and Power System } \\
\text { Planning }\end{array}$ & 13 & $86.67 \%$ & 2 & $13.33 \%$ & 15 & $86.67 \%$ & Included \\
\hline
\end{tabular}

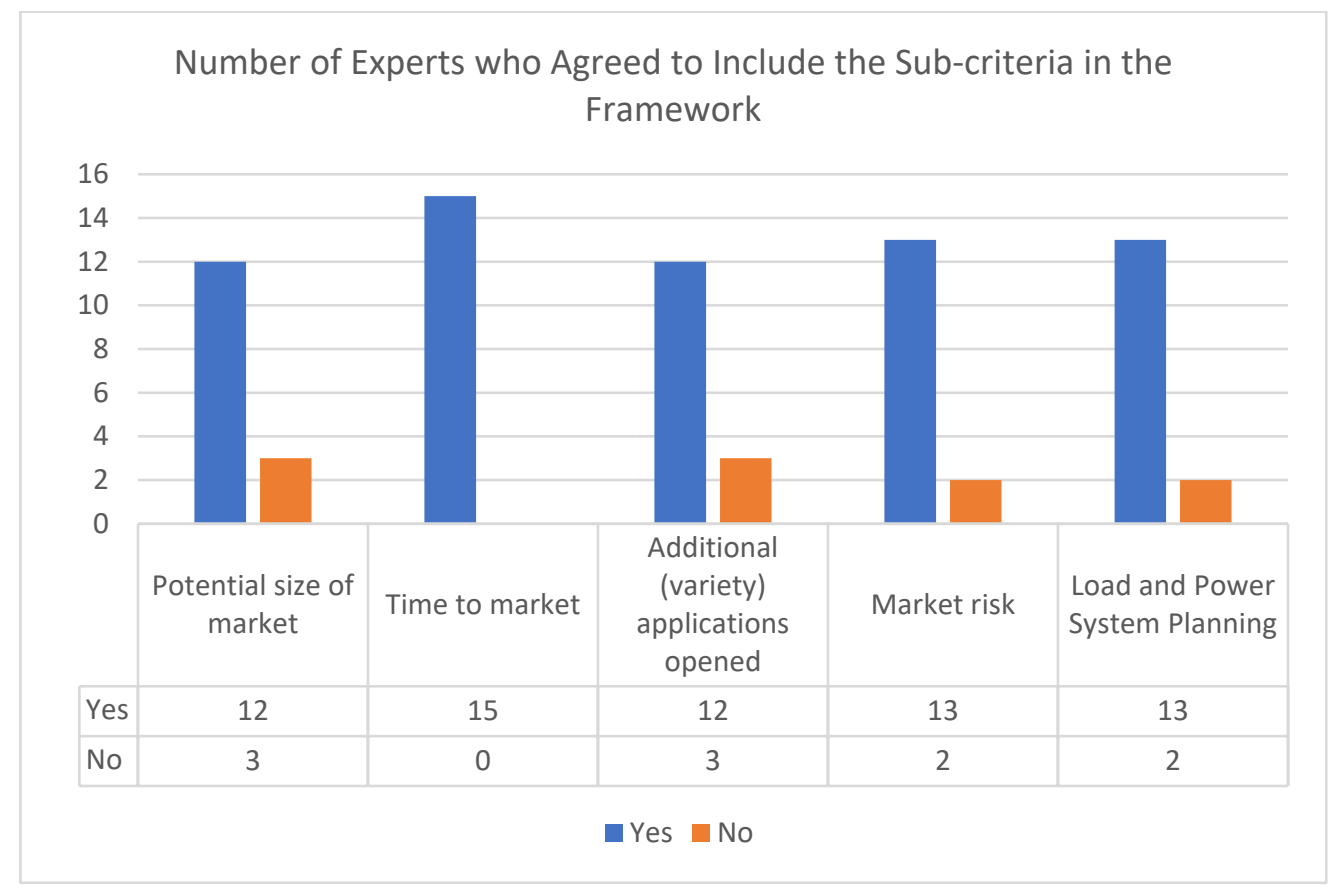

Figure 23: Market Criterion - Sub-Criteria Validation - Experts’ Responses 


\section{Organizational Criterion - Sub-criteria Validation}

Expert panel EP02 focused on validating the Organizational sub-criteria in satisfying the Organizational criterion. Content validity instrument RI2 was sent to the expert panel EP02. A total of 12 experts provided input. As a result, all Organizational subcriteria were accepted and included in the final model.

Table 29: Organizational Criterion - Sub-Criteria Validation - Experts' Responses Organizational Criterion

\begin{tabular}{|c|l|c|c|c|c|c|c|c|}
\hline \multicolumn{1}{|c|}{ Sub-criteria } & \multicolumn{2}{|c|}{ Yes } & \multicolumn{2}{c|}{ No } & Total & $\begin{array}{c}\text { Ratio } \\
\text { (Yes/Total) }\end{array}$ & Decision \\
\hline 1 & Research staff availability & 11 & $91.67 \%$ & 1 & $8.33 \%$ & 12 & $91.67 \%$ & Included \\
\hline 2 & Knowledge/skill availability & 11 & $91.67 \%$ & 1 & $8.33 \%$ & 12 & $91.67 \%$ & Included \\
\hline 3 & $\begin{array}{l}\text { Competence and experience on } \\
\text { similar projects }\end{array}$ & 11 & $91.67 \%$ & 1 & $8.33 \%$ & 12 & $91.67 \%$ & Included \\
\hline 4 & Strategic fit & 11 & $91.67 \%$ & 1 & $8.33 \%$ & 12 & $91.67 \%$ & Included \\
\hline 5 & Available facilities & 9 & $75.00 \%$ & 3 & $25.00 \%$ & 12 & $75.00 \%$ & Included \\
\hline
\end{tabular}

Number of Experts who Agreed to Include the Sub-criteria in the Framework

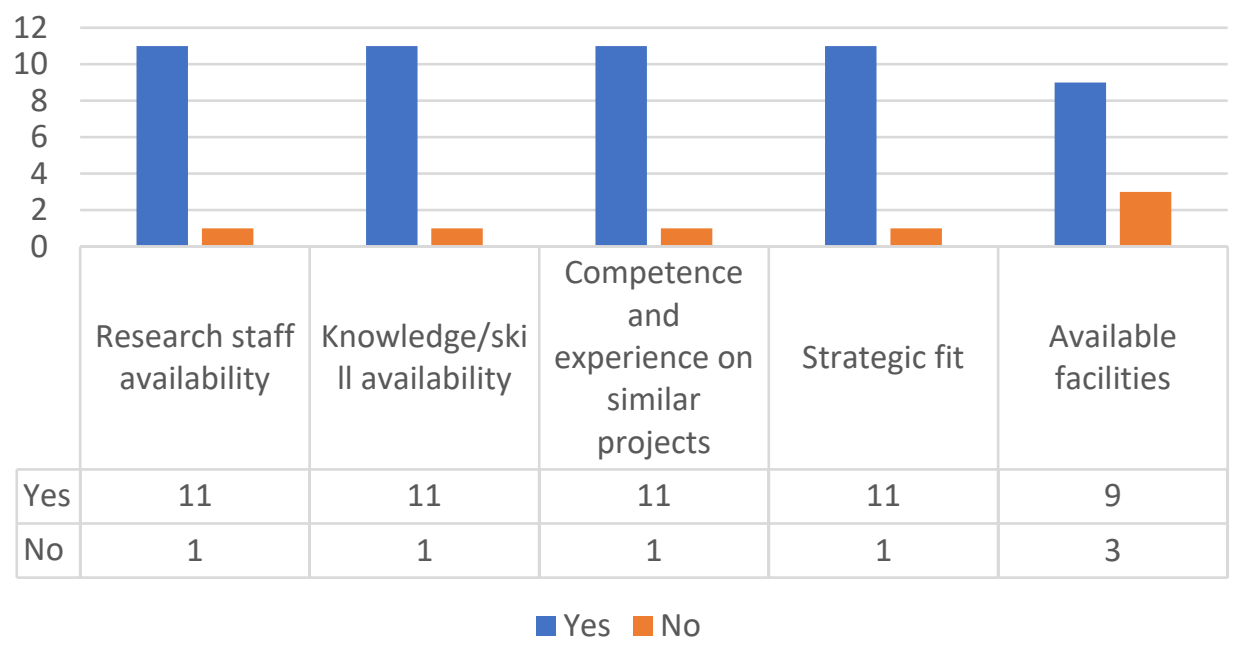

Figure 24: Organizational Criterion - Sub-Criteria Validation - Experts' Responses 


\section{Economic Criterion - Sub-criteria Validation}

Expert panel EP02 focused on validating the Economic sub-criteria in satisfying the Economic criterion. A total of 14 experts provided input in expert panel EP02 using research instrument RI2. All Economic sub-criteria were accepted and included in the final model.

Table 30: Economic Criterion - Sub-Criteria Validation - Experts' Responses

Economic Criterion

\begin{tabular}{|c|c|c|c|c|c|c|c|c|}
\hline & Sub-criteria & & Yes & & No & Total & $\begin{array}{c}\text { Ratio } \\
\text { (Yes/Total) }\end{array}$ & Decision \\
\hline 1 & Net present value (NPV) & 13 & $92.86 \%$ & 1 & $7.14 \%$ & 14 & $92.86 \%$ & Included \\
\hline 2 & $\begin{array}{l}\text { Value-added of target } \\
\text { products }\end{array}$ & 11 & $78.57 \%$ & 3 & $21.43 \%$ & 14 & $78.57 \%$ & Included \\
\hline 3 & Project cost & 14 & $100.00 \%$ & 0 & $0.00 \%$ & 14 & $100.00 \%$ & Included \\
\hline 4 & Economic risk & 13 & $92.86 \%$ & 1 & $7.14 \%$ & 14 & $92.86 \%$ & Included \\
\hline 5 & $\begin{array}{l}\text { Cost-Time Process } \\
\text { improvement }\end{array}$ & 7 & $50.00 \%$ & 7 & $50.00 \%$ & 14 & $50.00 \%$ & Excluded \\
\hline
\end{tabular}

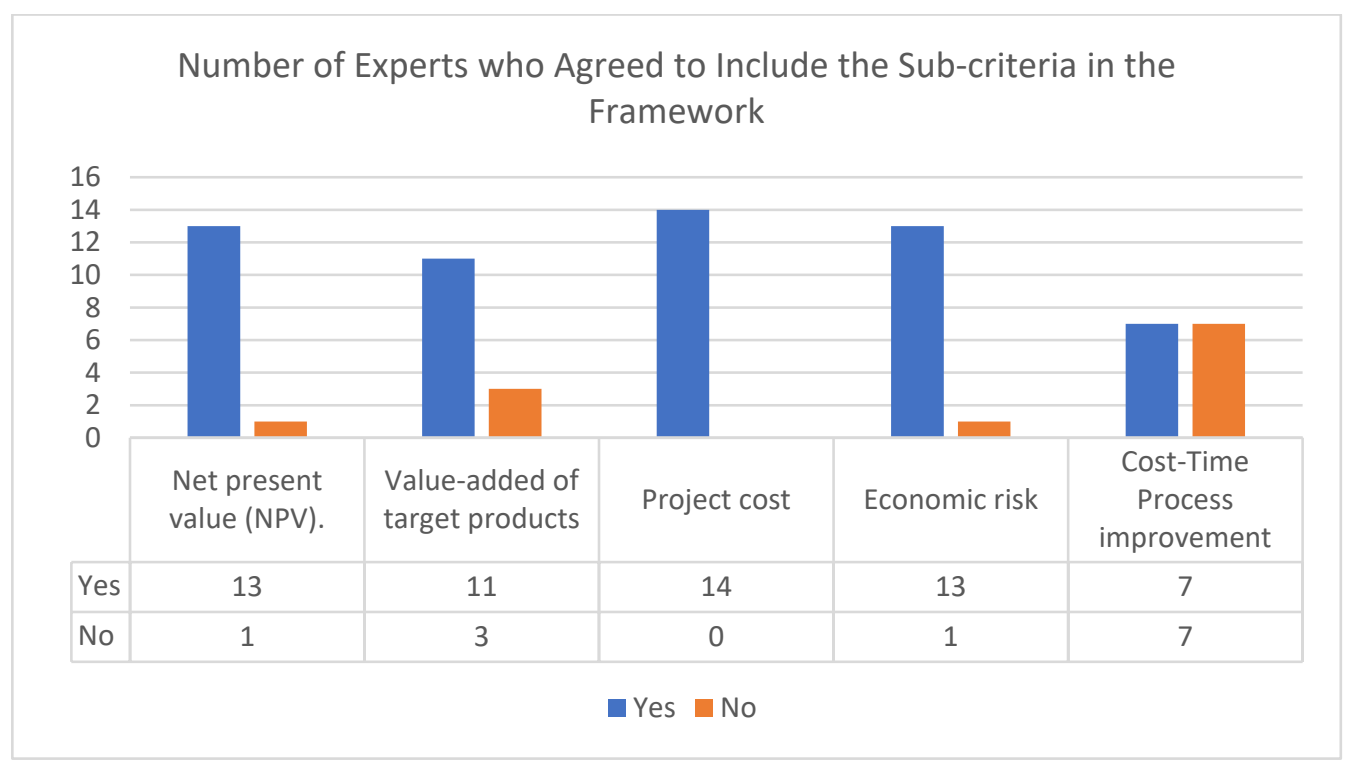

Figure 25: Economic Criterion - Sub-Criteria Validation - Experts' Responses 


\section{External/Regulation/Environmental Validation Criterion - Sub-criteria Validation}

Expert panel EP02 focused on validating the Environmental/Regulation sub-criteria in satisfying the Environmental/Regulation criterion. Content validity instrument RI2 was sent to the expert panel EP02. A total of 17 experts provided input and agreed to include in the model all Environmental/ Regulation sub-criteria.

Table 31: External/ Regulation/ Environmental Criterion - Sub-Criteria Validation - Experts' Responses External/ Regulation/ Environmental Criterion

\begin{tabular}{|c|l|c|c|c|c|c|c|c|}
\hline \multicolumn{1}{|c|}{ Sub-criteria } & \multicolumn{2}{|c|}{ Yes } & \multicolumn{2}{c|}{ No } & Total & $\begin{array}{c}\text { Ratio } \\
\text { (Yes/Total) }\end{array}$ & Decision \\
\hline 1 & Economic regulations & 16 & $94.12 \%$ & 1 & $5.88 \%$ & 17 & $94.12 \%$ & Included \\
\hline 2 & Environmental policy & 17 & $100.00 \%$ & 0 & $0.00 \%$ & 17 & $100.00 \%$ & Included \\
\hline 3 & $\begin{array}{l}\text { Reliability, resilience, state } \\
\text { Awareness technical } \\
\text { standards }\end{array}$ & 15 & $88.24 \%$ & 2 & $11.76 \%$ & 17 & $88.24 \%$ & Included \\
\hline 4 & Power Quality standards & 13 & $76.47 \%$ & 4 & $23.53 \%$ & 17 & $76.47 \%$ & Included \\
\hline 5 & Acceptance of stakeholders & 15 & $88.24 \%$ & 2 & $11.76 \%$ & 17 & $88.24 \%$ & Included \\
\hline
\end{tabular}

Number of Experts who Agreed to Include the Sub-criteria in the Framework

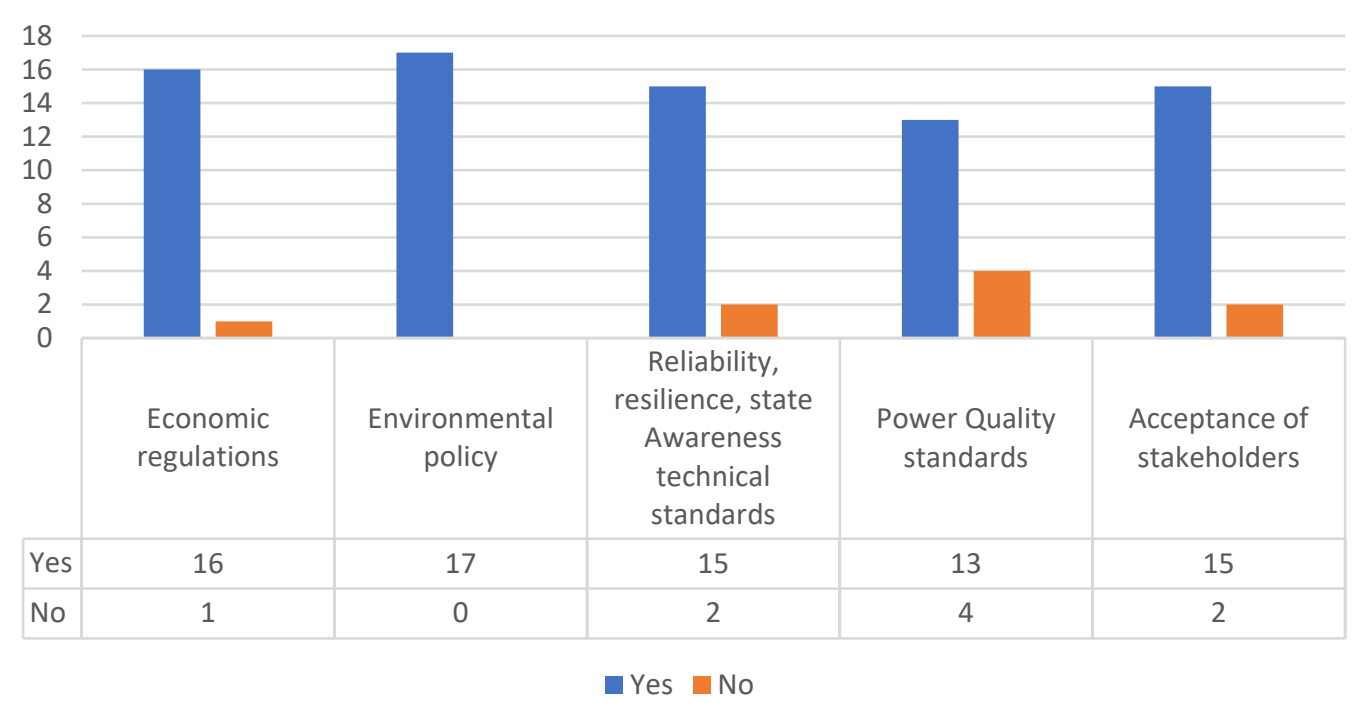

Figure 26: External/ Regulation/ Environmental Criterion - Sub-Criteria Validation - Experts' Responses 


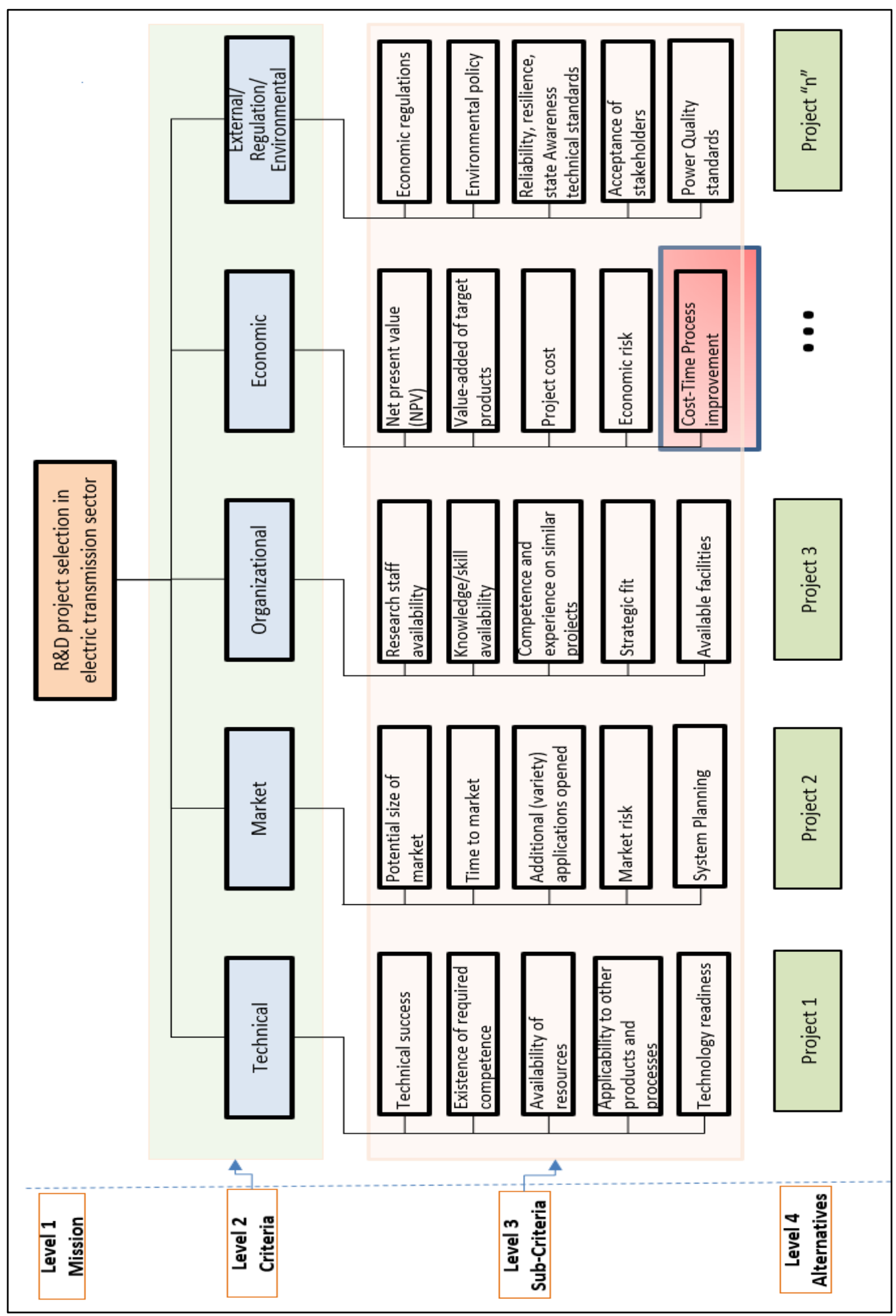

Figure 27: Pre-Validated HDM Model 
There were 32 experts identified who were grouped in 6 different panels. The experts were identified using Social Network Analysis and Snowballing methods. These experts were balanced according to their experience, affiliations, and locations. There were 10 to 20 experts in each panel (experts participated in 2 or more panels according to their expertise). It is important to mention that in the quantification part (not an objective of this paper), the same experts were used; however, the size of the panel varies from 6 to 11 experts.

The model validation had three principal results. First, all the criteria were validated with agreements higher than $67 \%$. Second, experts who validated the criteria suggested adding two sub-criteria. This model, including the additional sub-criteria suggested by experts, was validated by other experts who validate 23 out of 24 sub-criteria. The final model is shown below. 


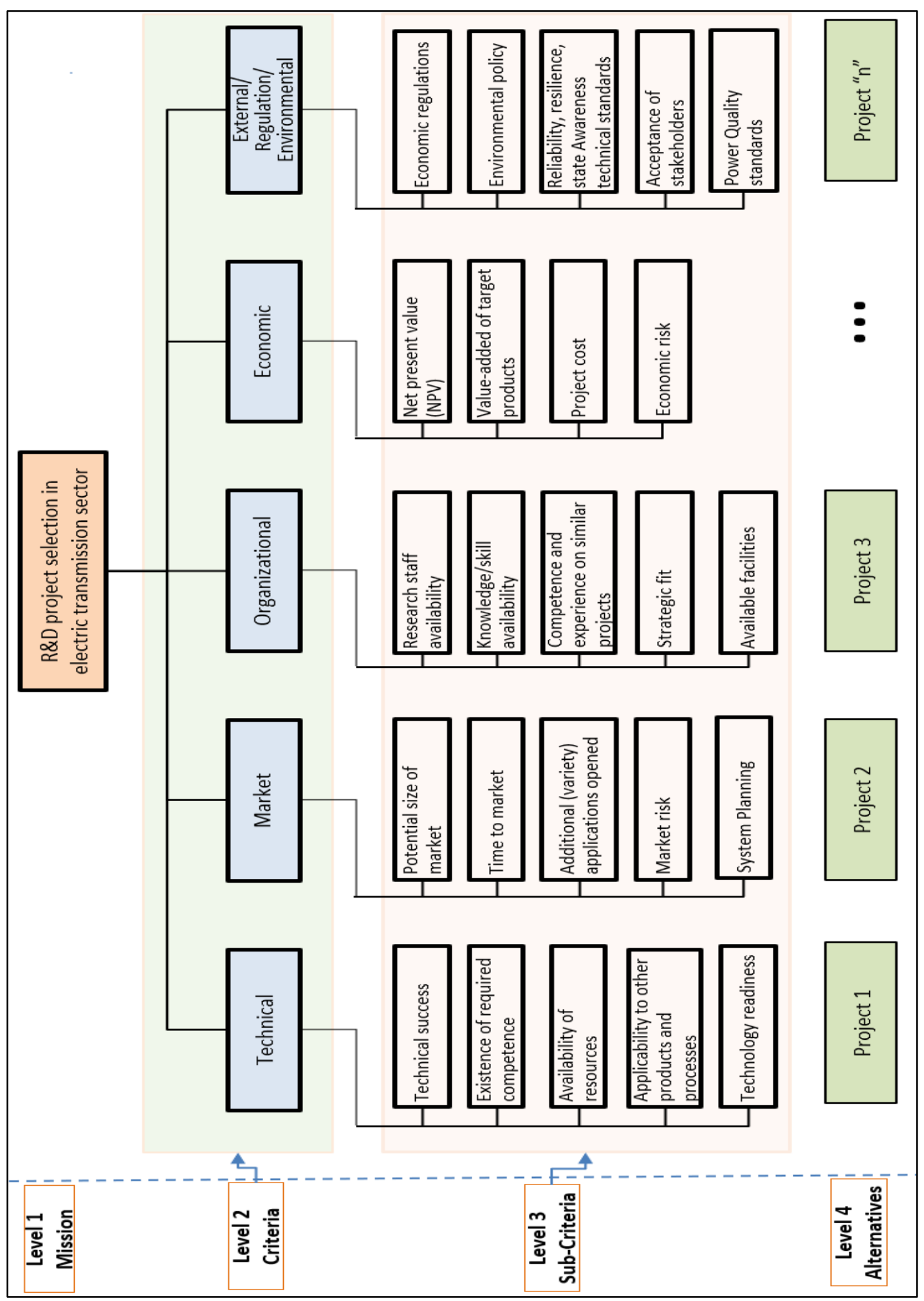

Figure 28: Validated HDM by Experts - Levels 1, 2, 3 


\subsection{Quantification of the Model}

The judgment quantification, experts' inconsistencies, and group disagreements for each expert panel are discussed below.

This section presents pairwise comparisons to determine the weights of the decision model. The expert panels EP1 and EP2, described above, received invitation letters and accepted to participate in the model quantification phase. Then, the experts received a link to a survey assessment tool to produce pairwise comparisons (research instruments RI3 and RI4). The panels were asked to distribute 100 points between two criteria or subcriteria, depending on the panel. This data was analyzed by using the Hierarchical Decision Model Software ${ }^{\circledR}$ to calculate the weights for each alternative, the inconsistency, and the disagreement.

The expert's inconsistency or group disagreement below the value of 0.1 was accepted. If there were groups with any disagreements, then the option of dividing the panel into subgroups would be considered (as shown below, it was not necessary).

It is important to mention that, in this part, the inconsistencies below 0.1 are used to have acceptable results, and it is not necessarily additional verification through the Ftest, which is frequently used to test inconsistency. This is a statistical test that is mostly used to decide if a statistical model is the best fit for a set of data using the least squares. However, it was found that the F-test is not reliable because it fails to explain identical or close judgments with no variance. Additionally, the F-test assumes a normal distribution, while the data might not be normally distributed [235]. 


\subsubsection{Criteria Quantification Results}

Expert Panel EP1 evaluated the relative importance of five criteria regarding their relative importance to the mission $(\mathrm{R} \& \mathrm{D}$ project selection in the electric transmission sector). There were 9 experts in Expert Panel EP1. The arithmetic means of the experts' judgments for the relative importance of considered criteria are shown in Table 32 below.

The initial results, as shown in Table 32, indicated that all the criteria were relatively important from an overall assessment point of view. The relative importance of the criteria to the mission is ranging from the relative value of 0.15 to 0.27 .

Table 32: Relative Importance of Criteria

\begin{tabular}{|l|c|c|c|c|c|c|}
\hline $\begin{array}{c}\text { R\&D project } \\
\text { selection in } \\
\text { electric } \\
\text { transmission } \\
\text { sector }\end{array}$ & Technical & Market & Organizational & Economic & $\begin{array}{c}\text { External/ } \\
\text { Regulation/ } \\
\text { Environmental }\end{array}$ & Inconsistency \\
\hline Expert 26 & 0.18 & 0.21 & 0.14 & 0.27 & 0.2 & 0.02 \\
\hline Expert 19 & 0.23 & 0.06 & 0.17 & 0.21 & 0.34 & 0.03 \\
\hline Expert 7 & 0.14 & 0.17 & 0.15 & 0.2 & 0.34 & 0.09 \\
\hline Expert 25 & 0.11 & 0.06 & 0.08 & 0.37 & 0.37 & 0.04 \\
\hline Expert 10 & 0.13 & 0.23 & 0.18 & 0.2 & 0.26 & 0.04 \\
\hline Expert 13 & 0.34 & 0.13 & 0.16 & 0.16 & 0.21 & 0.05 \\
\hline Expert 4 & 0.2 & 0.2 & 0.2 & 0.2 & 0.2 & 0 \\
\hline Expert 12 & 0.11 & 0.26 & 0.12 & 0.26 & 0.24 & 0.01 \\
\hline Expert 23 & 0.31 & 0 & 0.23 & 0.14 & 0.31 & 0.05 \\
\hline Mean & 0.19 & 0.15 & 0.16 & 0.22 & 0.27 & \\
\hline Minimum & 0.11 & 0 & 0.08 & 0.14 & 0.2 & \\
\hline Maximum & 0.34 & 0.26 & 0.23 & 0.37 & 0.37 & \\
\hline Std. Deviation & 0.08 & 0.08 & 0.04 & 0.06 & 0.06 & \\
\hline Disagreement & & & & & & 0.065 \\
\hline
\end{tabular}




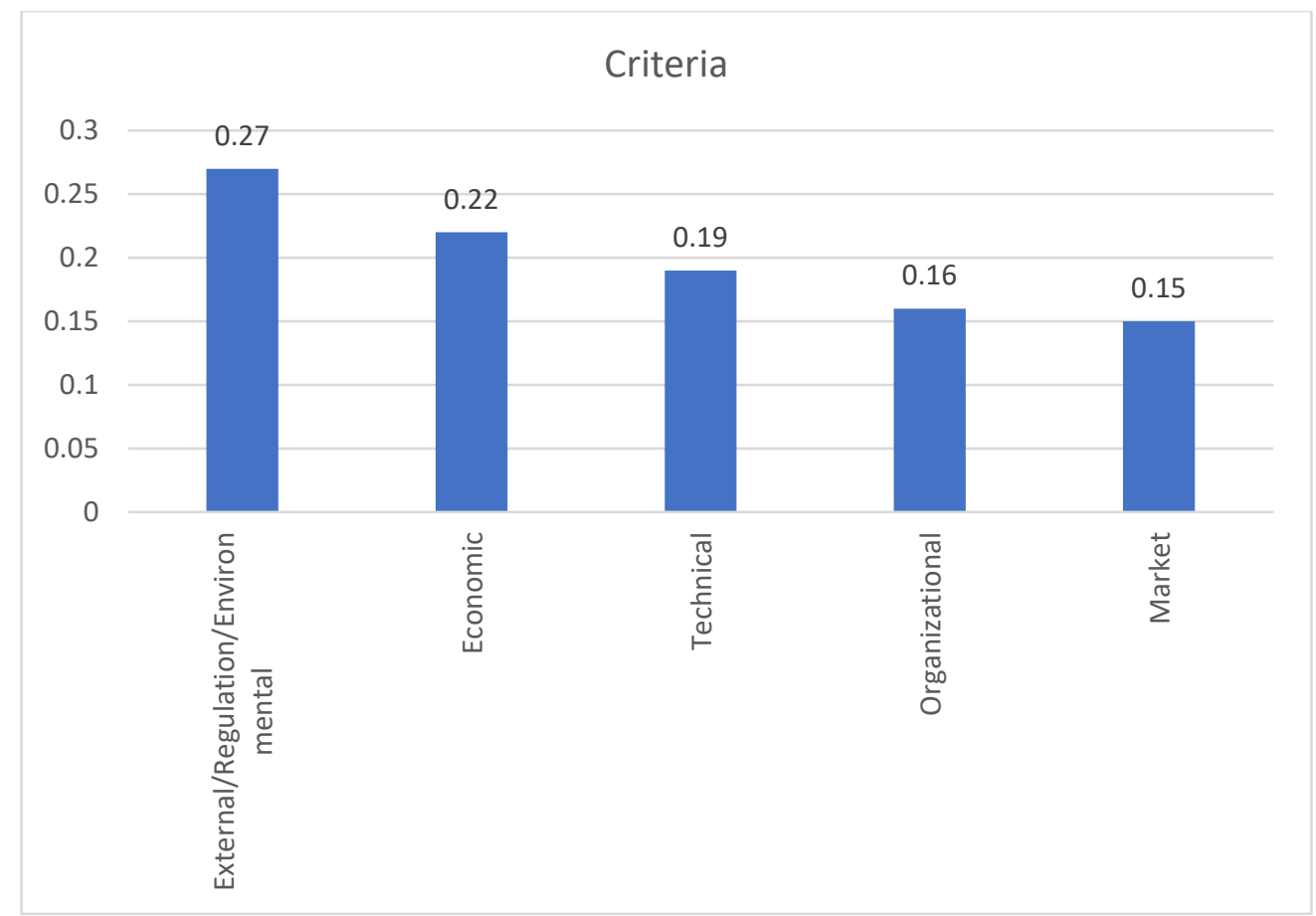

Figure 29: Relative Importance of Criteria

The inconsistency within each expert is acceptable (all $<0.10)$. This expert panel considered the External/Regulation/Environmental criterion as the most important (0.27).

\subsubsection{Sub-criteria Quantification Results}

\section{Technical Sub-Criterion Results}

Expert panel EP2 (7 participants) assessed the relative contribution of the five subcriteria to the technical criteria. The relative values are shown in Table 33. 
Table 33: Relative Importance of Technical Sub-criteria

\begin{tabular}{|l|c|c|c|c|c|c|}
\hline Technical & $\begin{array}{c}\text { Technical } \\
\text { success }\end{array}$ & $\begin{array}{c}\text { Existence of } \\
\text { required } \\
\text { competence }\end{array}$ & $\begin{array}{c}\text { Availability } \\
\text { of resources }\end{array}$ & $\begin{array}{c}\text { Applicability } \\
\text { to other } \\
\text { products and } \\
\text { processes }\end{array}$ & $\begin{array}{c}\text { Technology } \\
\text { readiness }\end{array}$ & Inconsistency \\
\hline Expert 16 & 0.25 & 0.09 & 0.22 & 0.16 & 0.28 & 0.04 \\
\hline Expert 25 & 0.31 & 0.12 & 0.13 & 0.08 & 0.37 & 0.04 \\
\hline Expert 28 & 0.14 & 0.23 & 0.27 & 0.21 & 0.15 & 0.01 \\
\hline Expert 27 & 0.3 & 0.29 & 0.17 & 0.16 & 0.08 & 0.09 \\
\hline Expert 5 & 0.36 & 0.29 & 0.19 & 0.08 & 0.08 & 0.07 \\
\hline Expert 4 & 0.2 & 0.2 & 0.2 & 0.2 & 0.2 & 0 \\
\hline Expert 15 & 0.35 & 0.17 & 0.26 & 0.07 & 0.15 & 0.08 \\
\hline Mean & 0.27 & 0.2 & 0.21 & 0.14 & 0.19 & \\
\hline Minimum & 0.14 & 0.09 & 0.13 & 0.07 & 0.08 & \\
\hline Maximum & 0.36 & 0.29 & 0.27 & 0.21 & 0.37 & \\
\hline $\begin{array}{l}\text { Std. } \\
\text { Deviation }\end{array}$ & 0.07 & 0.07 & 0.05 & 0.06 & 0.1 & 0.07 \\
\hline Disagreement & & & & & & \\
\hline
\end{tabular}

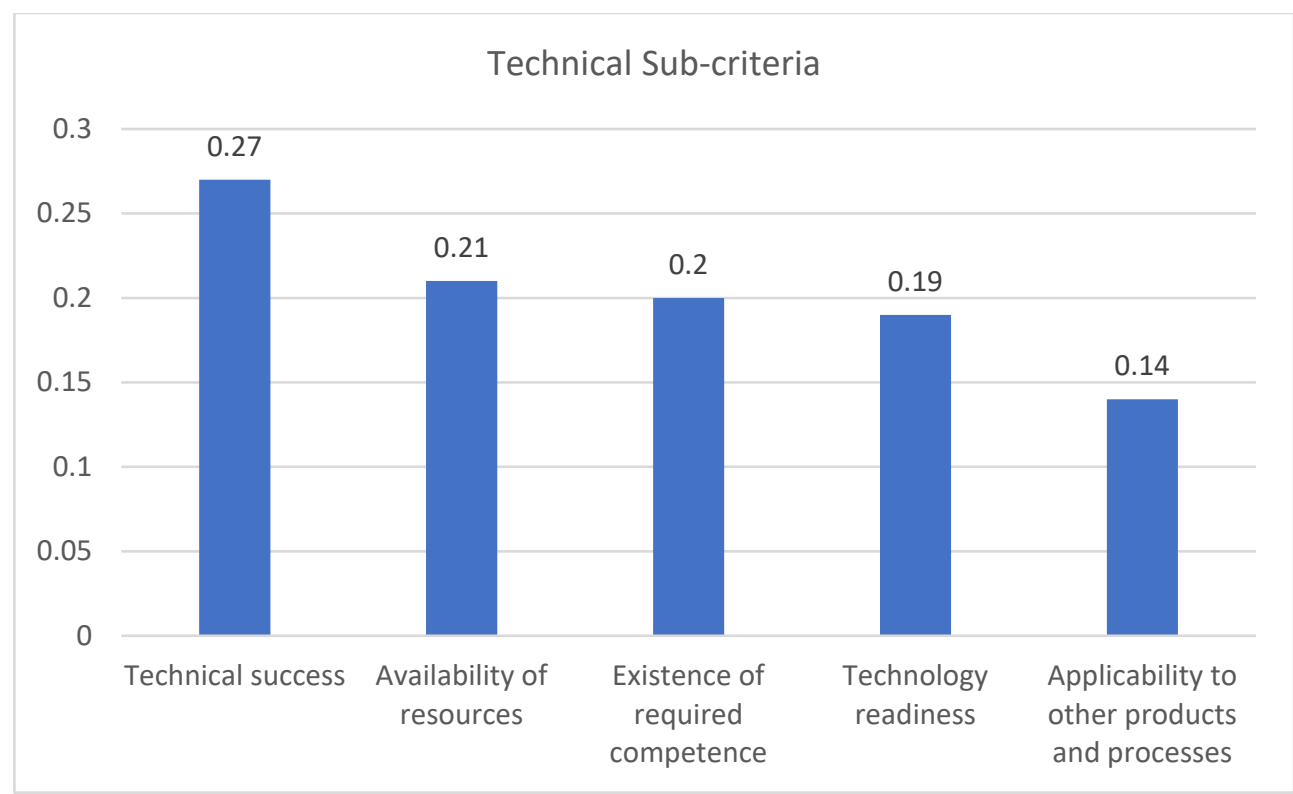

Figure 30: Relative Importance of Technical Sub-criterion

The inconsistency level within each expert is acceptable (all $<0.10)$. Since the values are acceptable, it is considered not necessary to use the F-test data. There is also no significant level of disagreement among experts (0.07). This expert panel considered the External/Regulation/Environmental sub-criterion as most important (0.27). 


\section{Market Sub-criteria Results}

Expert panel EP2 (7 participants) assessed the relative contribution of the five subcriteria to the Market criterion. The relative values are shown in Table 34.

Table 34: Relative Importance of Market Sub-criterion

\begin{tabular}{|l|c|c|c|c|c|c|}
\hline \multicolumn{1}{|c|}{ Market } & $\begin{array}{c}\text { Potential } \\
\text { size of } \\
\text { market }\end{array}$ & $\begin{array}{c}\text { Time to } \\
\text { market }\end{array}$ & $\begin{array}{c}\text { Additional } \\
\text { (variety) } \\
\text { applications } \\
\text { opened }\end{array}$ & $\begin{array}{c}\text { Market } \\
\text { risk }\end{array}$ & $\begin{array}{c}\text { System } \\
\text { Planning }\end{array}$ & Inconsistency \\
\hline Expert 8 & 0.2 & 0.27 & 0.12 & 0.32 & 0.09 & 0.06 \\
\hline Expert 1 & 0.23 & 0.23 & 0.2 & 0.14 & 0.2 & 0.03 \\
\hline Expert 18 & 0.11 & 0.2 & 0.23 & 0.13 & 0.32 & 0.01 \\
\hline Expert 11 & 0.18 & 0.08 & 0.28 & 0.27 & 0.2 & 0.03 \\
\hline Expert 9 & 0.27 & 0.33 & 0.05 & 0.17 & 0.18 & 0.08 \\
\hline Expert 14 & 0.28 & 0.24 & 0.18 & 0.15 & 0.16 & 0.02 \\
\hline Expert 2 & 0.13 & 0.22 & 0.07 & 0.19 & 0.38 & 0.02 \\
\hline Mean & 0.2 & 0.22 & 0.16 & 0.2 & 0.22 & \\
\hline Minimum & 0.11 & 0.08 & 0.05 & 0.13 & 0.09 & \\
\hline Maximum & 0.28 & 0.33 & 0.28 & 0.32 & 0.38 & \\
\hline $\begin{array}{l}\text { Std. } \\
\text { Deviation }\end{array}$ & 0.06 & 0.07 & 0.08 & 0.07 & 0.09 & \\
\hline Disagreement & & & & & & 0.072 \\
\hline
\end{tabular}

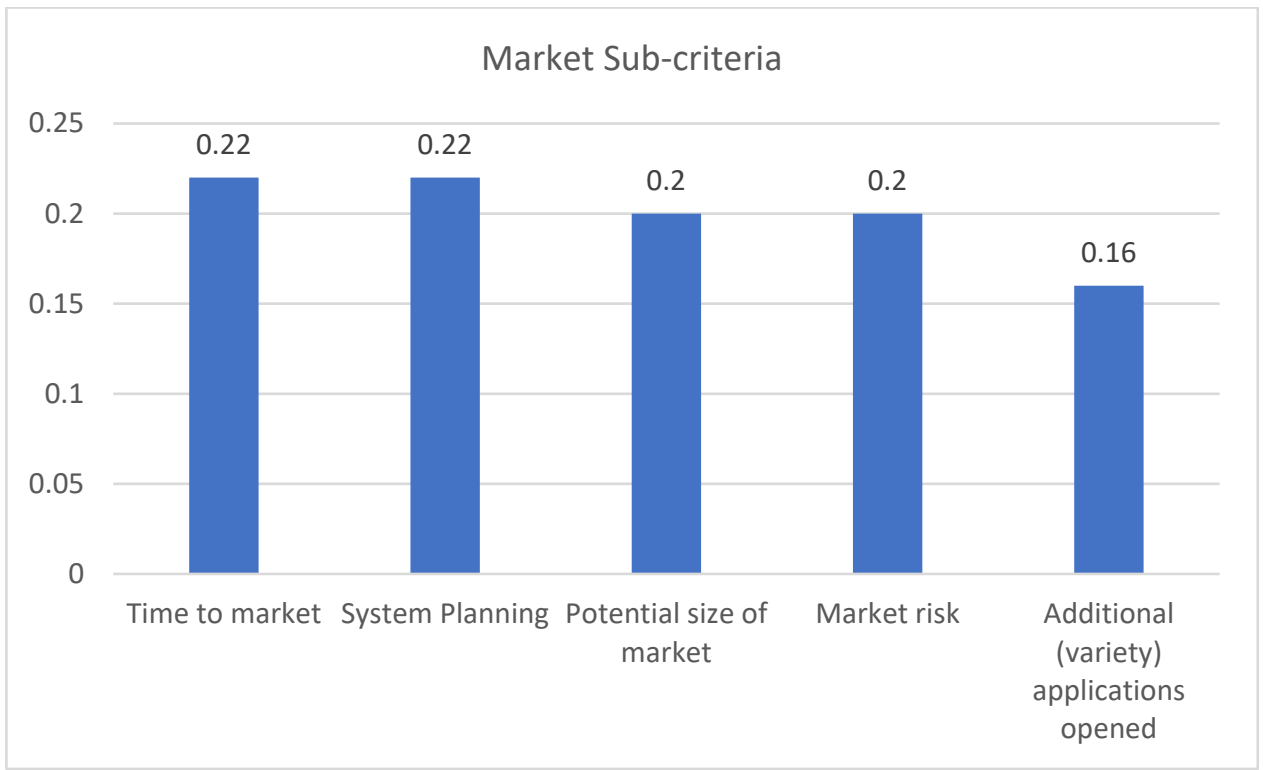

Figure 31: Relative Importance of Market Sub-criterion 
The inconsistency level within each expert is acceptable $($ all $<0.10)$. Since the values are acceptable, there is also no significant level of disagreement among experts (0.069). This expert panel considered the Potential Size of Market sub-criteria as most important (0.58).

\section{Organizational Sub-criterion Results}

Expert panel EP2 (8 participants) assessed the relative contribution of the five subcriteria to the Strategic Fit criterion. The corresponding values are shown in Table 35.

Table 35: Relative Importance of Organizational Sub-criteria

\begin{tabular}{|l|c|c|c|c|c|c|}
\hline Organizational & $\begin{array}{c}\text { Research } \\
\text { staff } \\
\text { availability }\end{array}$ & $\begin{array}{c}\text { Knowledge/ } \\
\text { skill } \\
\text { availability }\end{array}$ & $\begin{array}{c}\text { Competence } \\
\text { and } \\
\text { experience on } \\
\text { similar } \\
\text { projects }\end{array}$ & $\begin{array}{c}\text { Strategic } \\
\text { fit }\end{array}$ & $\begin{array}{c}\text { Available } \\
\text { facilities }\end{array}$ & Inconsistency \\
\hline Expert 1 & 0.09 & 0.16 & 0.28 & 0.26 & 0.21 & 0.02 \\
\hline Expert 16 & 0.22 & 0.19 & 0.11 & 0.33 & 0.15 & 0.04 \\
\hline Expert 21 & 0.12 & 0.24 & 0.1 & 0.47 & 0.07 & 0.07 \\
\hline Expert 25 & 0.09 & 0.33 & 0.26 & 0.17 & 0.14 & 0.02 \\
\hline Expert 3 & 0.11 & 0.18 & 0.21 & 0.41 & 0.08 & 0.05 \\
\hline Expert 28 & 0.15 & 0.25 & 0.27 & 0.19 & 0.14 & 0.02 \\
\hline Expert 12 & 0.23 & 0.23 & 0.2 & 0.17 & 0.17 & 0 \\
\hline Expert 23 & 0.24 & 0.2 & 0.2 & 0.17 & 0.2 & 0.01 \\
\hline Mean & 0.16 & 0.22 & 0.2 & 0.27 & 0.15 & \\
\hline Minimum & 0.09 & 0.16 & 0.1 & 0.17 & 0.07 & \\
\hline Maximum & 0.24 & 0.33 & 0.28 & 0.47 & 0.21 & \\
\hline Std. Deviation & 0.06 & 0.05 & 0.06 & 0.11 & 0.05 & \\
\hline Disagreement & & & & & & 0.069 \\
\hline
\end{tabular}

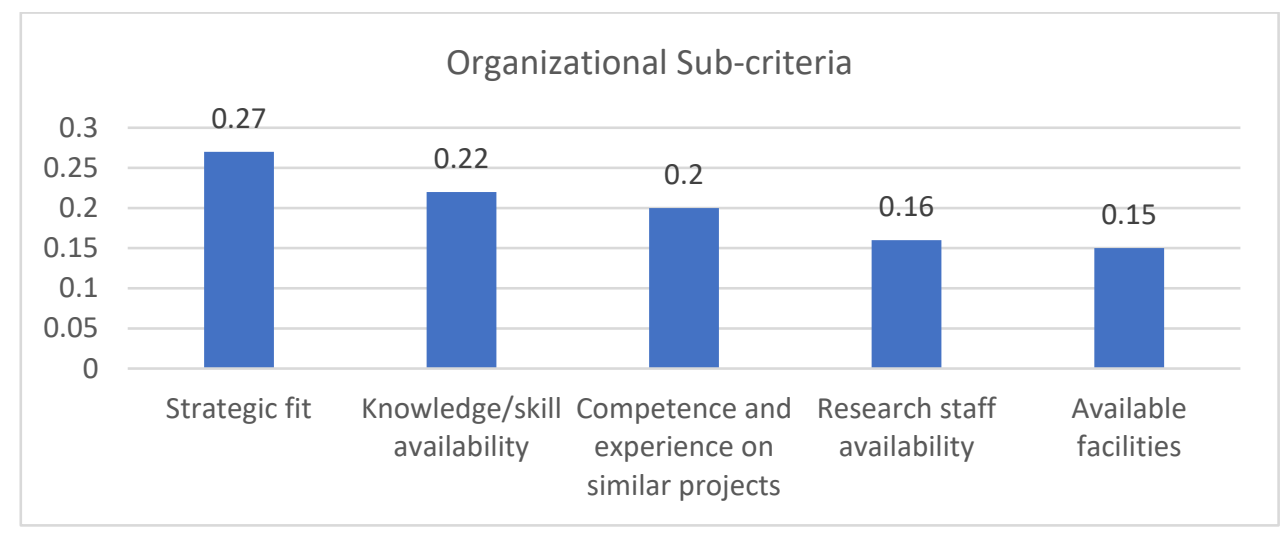

Figure 32: Relative Importance of Organizational Sub-criterion 
The inconsistency level within each expert is acceptable (all $<0.10)$. Since the values are acceptable, it is considered not necessary to use the F-test data (see the note above about using the F-test). There is also no significant level of disagreement among experts (0.069). This expert panel considered the Strategic Fit sub-criteria as most important (0.27).

\section{Economic Sub-criteria Results}

Expert panel EP2 (8 participants) assessed the relative contribution of the three sub-criteria to the Economic criterion. The corresponding values are shown in Table 36.

Table 36: Relative Importance of Economic Sub-criterion

\begin{tabular}{|l|c|c|c|c|c|}
\hline \multicolumn{1}{|c|}{ Economic } & $\begin{array}{c}\text { Net present } \\
\text { value (NPV) }\end{array}$ & $\begin{array}{c}\text { Value-added of } \\
\text { target products }\end{array}$ & $\begin{array}{c}\text { Project } \\
\text { cost }\end{array}$ & $\begin{array}{c}\text { Economic } \\
\text { risk }\end{array}$ & Inconsistency \\
\hline Expert 26 & 0.23 & 0.4 & 0.21 & 0.15 & 0.01 \\
\hline Expert 8 & 0.14 & 0.29 & 0.24 & 0.32 & 0.02 \\
\hline Expert 18 & 0.17 & 0.13 & 0.31 & 0.39 & 0.01 \\
\hline Expert 7 & 0.18 & 0.34 & 0.29 & 0.18 & 0.06 \\
\hline Expert 21 & 0.25 & 0.23 & 0.26 & 0.26 & 0.09 \\
\hline Expert 9 & 0.33 & 0.32 & 0.14 & 0.2 & 0.01 \\
\hline Expert 2 & 0.17 & 0.37 & 0.17 & 0.29 & 0.08 \\
\hline Expert 15 & 0.33 & 0.18 & 0.23 & 0.26 & 0.01 \\
\hline Mean & 0.23 & 0.28 & 0.23 & 0.26 & \\
\hline Minimum & 0.14 & 0.13 & 0.14 & 0.15 & \\
\hline Maximum & 0.33 & 0.4 & 0.31 & 0.39 & \\
\hline Std. & 0.09 & 0.05 & 0.07 & \\
\hline Deviation & 0.07 & & & & 0.069 \\
\hline Disagreement & & & & & \\
\hline
\end{tabular}




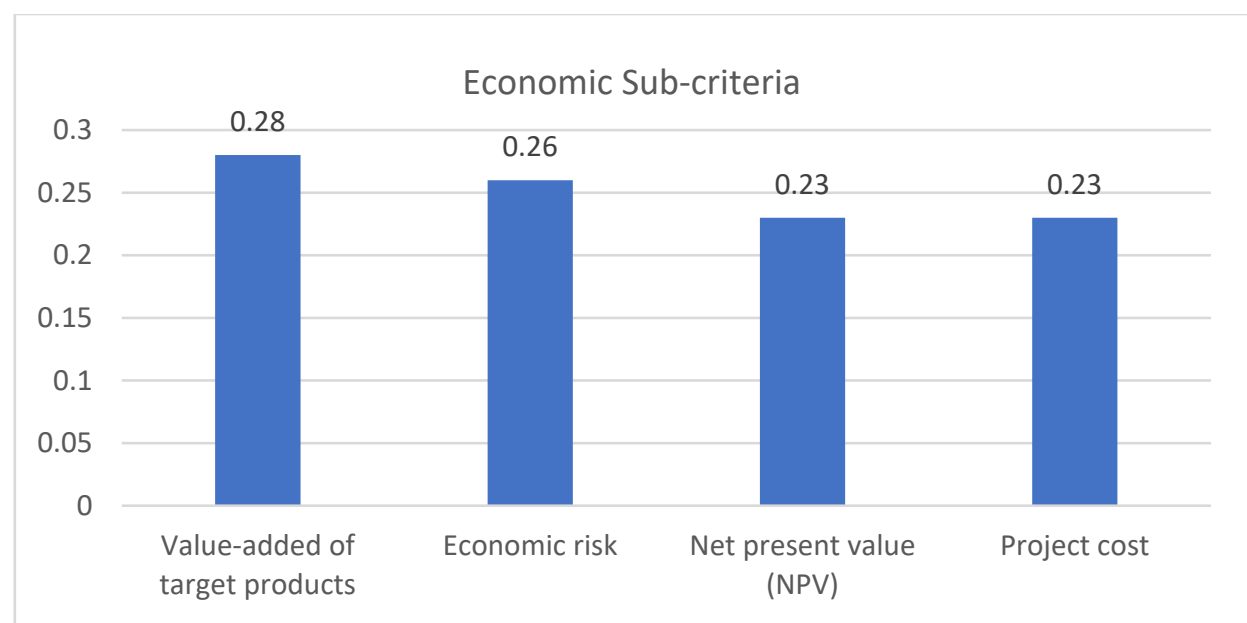

Figure 33: Relative Importance of Economic Sub-criterion

The inconsistency level within each expert is acceptable $($ all $<0.10)$. Since the values are acceptable, it is considered not necessary to use the F-test data (see the note above about using the F-test). There is also no significant level of disagreement among experts (0.069). This expert panel considered the Value-added of Target Products subcriteria as most important (0.28).

\section{External/Regulation/ Environmental Sub-criterion Results}

Expert panel EP2 (6 participants) assessed the relative contribution of the five subcriteria to the Environmental/Regulation criterion. The relative values are shown in Table 37. There is also no significant level of disagreement among experts (0.073). The inconsistency within each expert is acceptable (all $<0.10)$. This expert panel considered the Reliability, Resilience, State Awareness Technical Standards sub-criterion as the most important (0.23). 
Table 37: Relative Importance of External/Regulation/Environmental Sub-criteria

\begin{tabular}{|l|c|c|c|c|c|c|}
\hline $\begin{array}{c}\text { External/ } \\
\text { Regulation/ } \\
\text { Environmental }\end{array}$ & Economic & Eegulations & $\begin{array}{c}\text { Reliability, } \\
\text { resilience, } \\
\text { state } \\
\text { policy } \\
\text { Awareness } \\
\text { technical } \\
\text { standards }\end{array}$ & $\begin{array}{c}\text { Acceptance } \\
\text { of } \\
\text { stakeholders }\end{array}$ & $\begin{array}{c}\text { Power } \\
\text { Quality } \\
\text { standards }\end{array}$ & Inconsistency \\
\hline Expert 19 & 0.15 & 0.34 & 0.15 & 0.22 & 0.15 & 0 \\
\hline Expert 11 & 0.25 & 0.15 & 0.25 & 0.19 & 0.15 & 0.03 \\
\hline Expert 25 & 0.08 & 0.13 & 0.33 & 0.02 & 0.43 & 0.09 \\
\hline Expert 10 & 0.24 & 0.21 & 0.18 & 0.17 & 0.2 & 0.02 \\
\hline Expert 14 & 0.22 & 0.17 & 0.15 & 0.27 & 0.19 & 0.01 \\
\hline Expert 13 & 0.13 & 0.23 & 0.34 & 0.1 & 0.2 & 0.05 \\
\hline Mean & 0.18 & 0.21 & 0.23 & 0.16 & 0.22 & \\
\hline Minimum & 0.08 & 0.13 & 0.15 & 0.02 & 0.15 & \\
\hline Maximum & 0.25 & 0.34 & 0.34 & 0.27 & 0.43 & \\
\hline Std. Deviation & 0.06 & 0.07 & 0.08 & 0.08 & 0.1 & \\
\hline Disagreement & & & & & & 0.073 \\
\hline
\end{tabular}

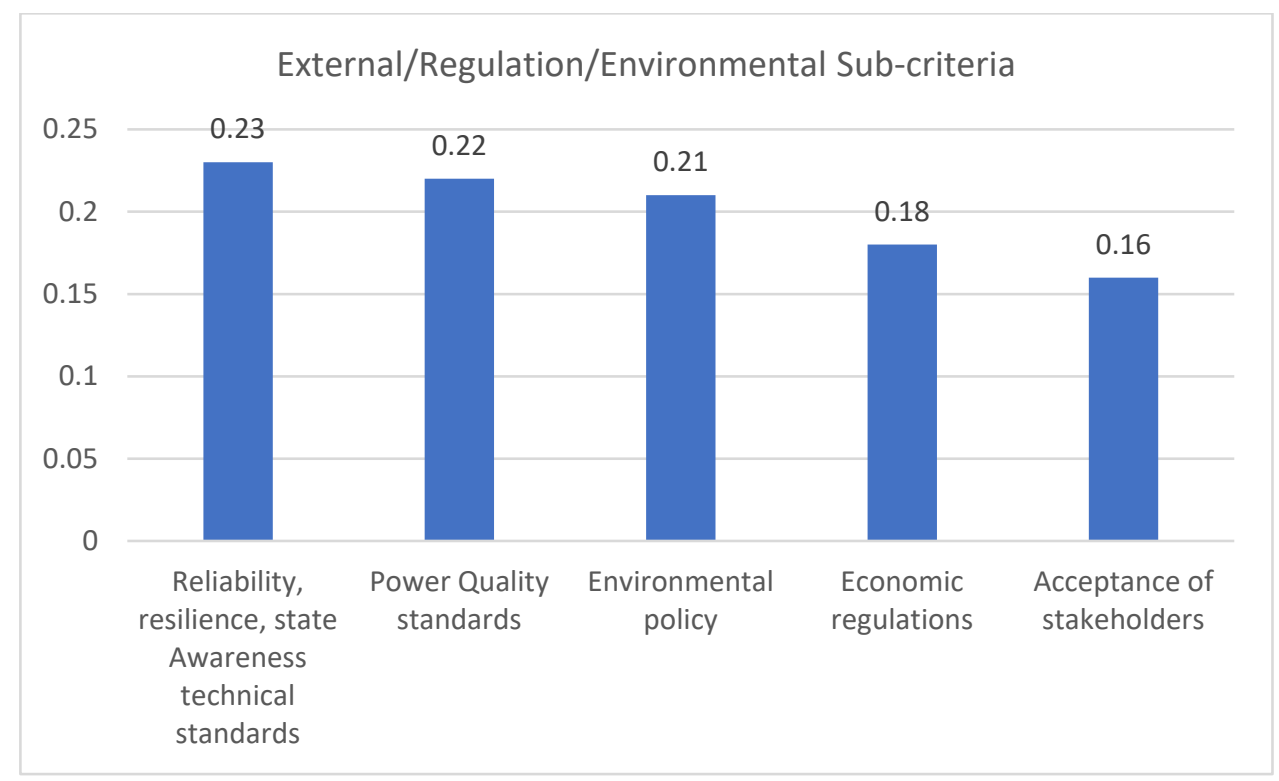

Figure 34: Relative Importance of External/Regulation/Environmental Sub-criterion 


\subsubsection{Quantification: Analysis of the Differences Between Criteria}

The relative values of criteria with respect to the mission are very close; therefore, a statistical analysis was performed to see if there is any statistical difference among the relative value.

As the first step, it is assumed that the data is normally distributed. Under the assumptions that the data is independent and identically distributed, the data are Normal, and for two independent sample (unpaired) $t$-tests, it is assumed that variance of the two groups is equal which typically holds unless there is an internal structure. As a second step, normality and equal variance are tested.
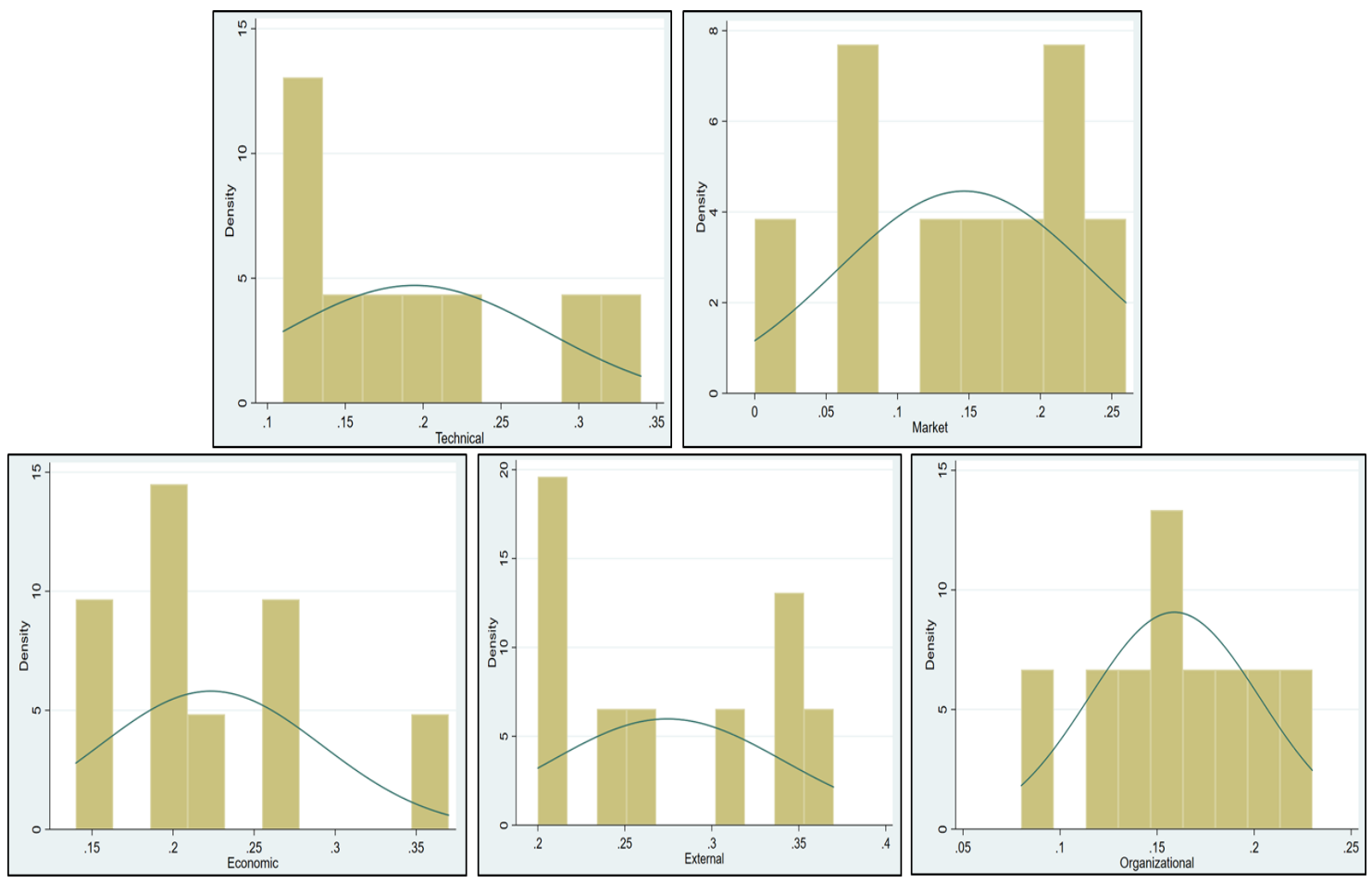

Figure 35: Graphical (histogram) Test for Normality 


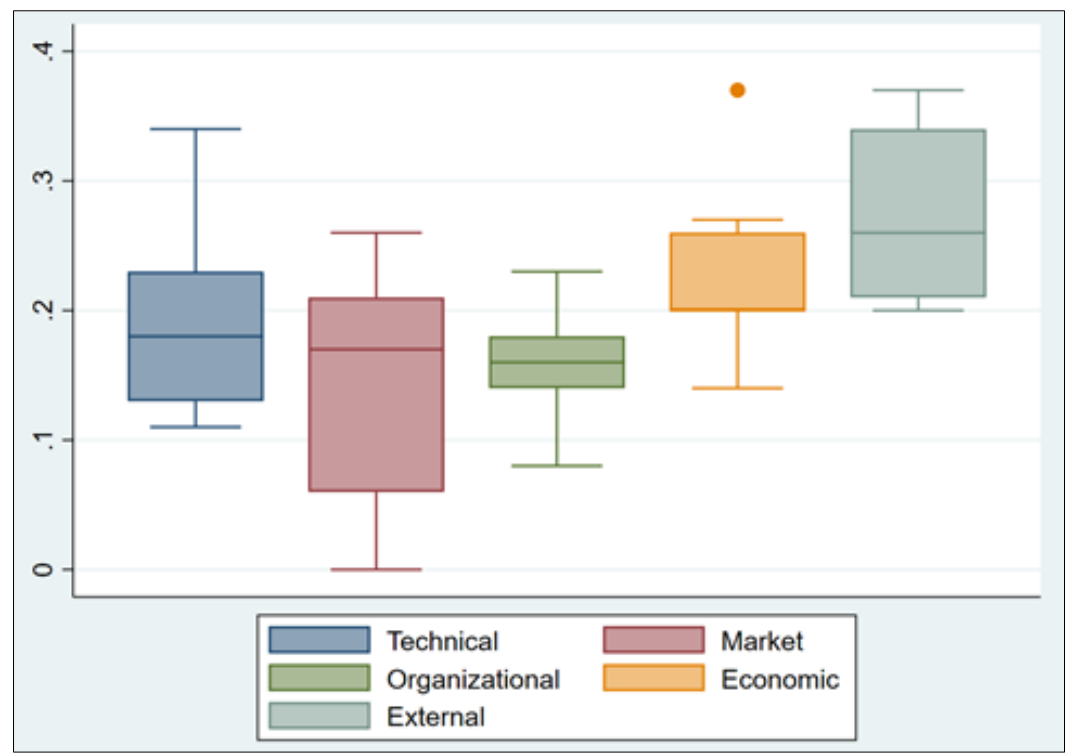

Figure 36" Graphical (Box Plot) - Test for Normality

Table 38: Shapiro -Wilk and Shapiro -Francia Tests for Normality

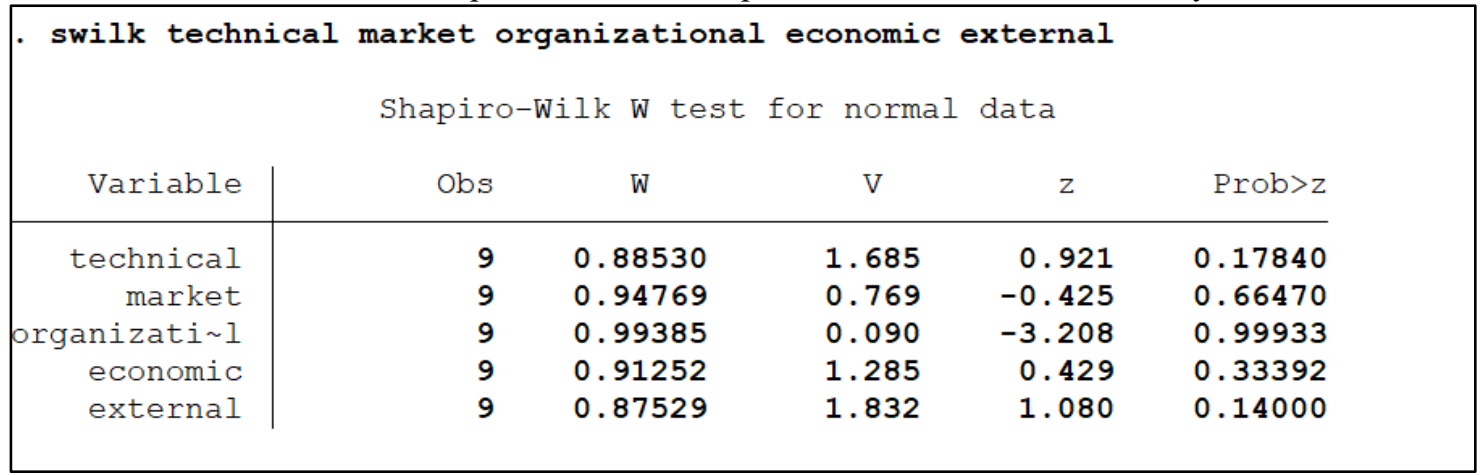

A Numerical Method (Shapiro-Wilk and Shapiro-Francia tests for normality) was performed; the results do not reject the null hypothesis that the data is not normally distributed (Prob. $>0.05$ ). All variables appear normally distributed $\mathrm{P}<0.05$ ). However, a graphical method, visualizing the Box Plots and histograms, shows non normal distributions in most of the criteria. By visualizing the histograms, it appears that the variables are not normally distributed, contradicting the "Shapiro-Wilk W test." 
The normality test results are not consistent (Q-Q plots). Since the Q-Q plots show that criteria are not normally distributed, a log transformation of data was performed (Appendix B). The Q-Q plots do show no clear normality of the distribution of the data, even using logarithms, therefore "t statistic" test cannot be performed because the sample size in each group is not $\geq 30$ (Rule of Thumb).

Equal Variance Tests were performed for all the criteria pairs (Appendix B). All pairs of variable variances were found to be equal in an F-test, except for "market and economic." Consequently, equal variances can be used except in the case of "marketeconomic."

The 'no consistency' and 'not clear' results from numerical and graphic methods testing for normality are due to the amount of data $(<30)$. Since we cannot rely on the specific assumptions, "nonparametric" tests are performed. The Kruskal-Wallis rank test Anova in non-normal heteroskedastic cases was tested, showing that there is at least one variable different. 
Table 39: Kruskal-Wallis rank test Anova

\begin{tabular}{|c|c|c|c|c|}
\hline \multicolumn{5}{|c|}{$\begin{array}{l}\text { kwallis score, by(score) } \\
\text { Kruskal-Wallis equality-of-populations }\end{array}$} \\
\hline score & Obs & Rank Sum & & \\
\hline 0 & 1 & 1.00 & & \\
\hline $\begin{array}{l}.06 \\
.08\end{array}$ & $\begin{array}{l}2 \\
1\end{array}$ & $\begin{array}{l}5.00 \\
4.00\end{array}$ & $\begin{array}{l}\text { Category } \\
\text { number }\end{array}$ & Criterion \\
\hline .11 & 2 & 11.00 & & \\
\hline .12 & 1 & 7.00 & 1 & Technological \\
\hline .13 & 2 & 17.00 & & \\
\hline & $\begin{array}{l}3 \\
1\end{array}$ & $\begin{array}{l}33.00 \\
13.00\end{array}$ & 2 & Market \\
\hline .16 & 2 & 29.00 & & \\
\hline .17 & 2 & 33.00 & 3 & Organizational \\
\hline .18 & 2 & 37.00 & & \\
\hline & $\begin{array}{l}8 \\
3\end{array}$ & $\begin{array}{r}188.00 \\
87.00\end{array}$ & 4 & Economic \\
\hline .23 & 3 & 96.00 & & \\
\hline .24 & 1 & 34.00 & 5 & External \\
\hline .26 & 3 & 108.00 & & \\
\hline .27 & 1 & 38.00 & & \\
\hline .31 & 2 & 79.00 & & \\
\hline .34 & 3 & 126.00 & & \\
\hline .37 & 2 & 89.00 & & \\
\hline $\begin{array}{l}\text { chi-squared } \\
\text { probability }\end{array}$ & $\begin{array}{l}= \\
=\end{array}$ & $\begin{array}{l}43.675 \text { with } \\
0.0010\end{array}$ & 19 d.f. & \\
\hline $\begin{array}{l}\text { chi-squared } \\
\text { probability }\end{array}$ & $\begin{array}{l}\text { with } \\
=\end{array}$ & $\begin{array}{l}\text { ties }= \\
0.0009\end{array}$ & 4.000 with & 19 d.f. \\
\hline
\end{tabular}

In order to identify what variable is different, Sidak, Bonferroni, Scheffe Tests were performed. All the results show that there are no significant differences among the mean between variables, except for the pairs 2-5 (market - external/environmental/regulation) and 3-5 (organizational - external/environmental/regulation). 


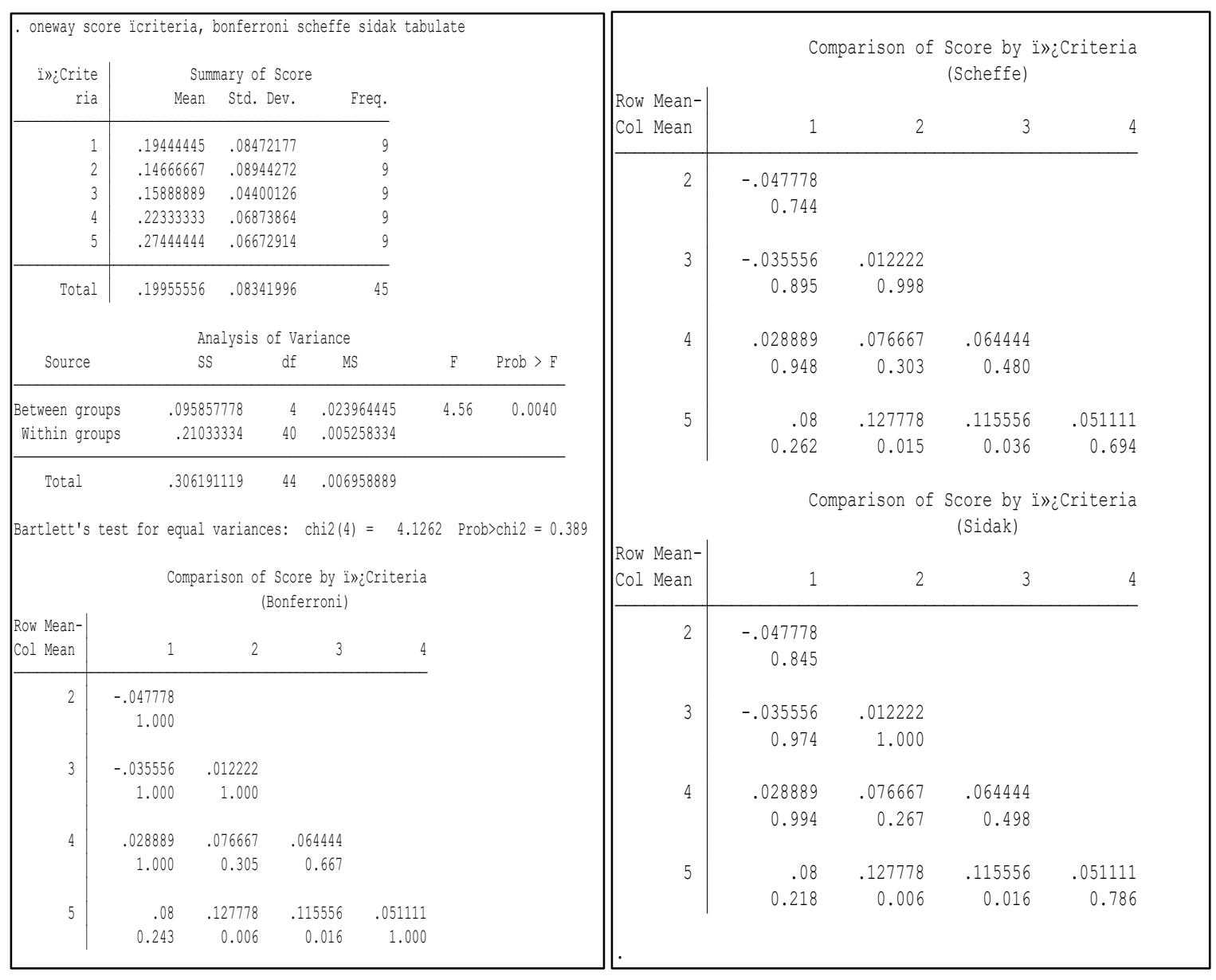

Table 40: Post-Hoc Pairwise Comparisons 


\section{CHAPTER 8: CASE STUDY}

\subsection{Overview of Case Application Organization}

The application of the model is focused on the U.S. Northwest, specifically on the utilities that transport electrical energy. The model is built considering an electrical utility as the decision-maker. The projects to be analyzed are at Bonneville Power Administration (BPA). BPA is a Federal Electric Utility (FEU) in the Pacific Northwest. As one of the main electrical utilities in the Northwest, experts who quantify the criteria, sub-criteria, and alternatives (providing the weights), and validate the model are selected from BPA. The application of the research is focused on power transmission technology projects.

Based on an initial interview at BPA, the contact-point expert's areas were:

- BPA - Project Managers

- BPA - Technology Planning

- $\quad$ BPA - Technology Innovation

The Northwest power pool is integrated by many states; which are Washington, Oregon, Idaho, Wyoming, Montana, Nevada, and Utah, a small part of Northern California, and the Canadian provinces of British Columbia and Alberta [251].

As transmission utility, BPA is considered important in the Northwest of the U.S., as was mentioned by Energy Secretary Ernest Moniz, 2014: “The Bonneville Power Administration is vitally important to serving the energy needs of the Pacific Northwest and contributes greatly to the Energy Department's mission [252]." BPA markets the electricity generated by that plant and also acts as the balancing authority for the region, 
which means it ensures that electricity supply matches electricity demand at all times [253]. BPA provides about 28 percent of the electric power used in the Northwest, mainly based on hydroelectric generation. BPA also operates and maintains about three-fourths of the high-voltage transmission in its service territory [254].

Table 41: BPA's Customers and Organization Type

\begin{tabular}{|c|c|c|c|}
\hline \multicolumn{2}{|c|}{ BPA's Customers } & Type of Organization & Organizations \\
\hline Cooperatives & 54 & Publicly Owned Utilities & $\begin{array}{l}\text { West Oregon Electric Coop., } \\
\text { Central Electric Coop, } \\
\text { Blachly- Lane Co. Coop, } \\
\text { Midstate Electric Coop. }\end{array}$ \\
\hline Municipalities & 42 & Publicly Owned Utilities & $\begin{array}{l}\text { Seattle City Light (Washington) } \\
\text { Tacoma Power in Washington } \\
\text { Eugene Water (Oregon) } \\
\text { Electric Board in Oregon }\end{array}$ \\
\hline $\begin{array}{l}\text { Public utility } \\
\text { districts }\end{array}$ & 28 & Publicly Owned Utilities & $\begin{array}{l}\text { Snohomish County Public Utility } \\
\text { District in Everett } \\
\text { Washington, Tillamook PUD } \\
\text { Central Lincoln PUD } \\
\text { Emerald PUD }\end{array}$ \\
\hline $\begin{array}{l}\text { Federal } \\
\text { agencies }\end{array}$ & 7 & Direct Service Industries (“DSIs”) & $\begin{array}{l}\text { U.S. Bureau of Reclamation } \\
\text { U.S. Bureau of Mines } \\
\text { Fairchild Air Force Base } \\
\text { U.S. Navy bases (Puget Sound Naval } \\
\text { Yard, Jim Creek, Bangor) } \\
\text { Department of Energy, Richland- } \\
\text { Midway }\end{array}$ \\
\hline $\begin{array}{l}\text { Investor- } \\
\text { owned utilities }\end{array}$ & 6 & Investor-owned Utilities (IOUs) & $\begin{array}{l}\text { Avista } \\
\text { Idaho Power Co. } \\
\text { NorthWestern Energy } \\
\text { PacifiCorp } \\
\text { Portland General Electric } \\
\text { Puget Sound Energy }\end{array}$ \\
\hline $\begin{array}{l}\text { Direct-service } \\
\text { industries } \\
\text { (DSIs) }\end{array}$ & 2 & $\begin{array}{l}\text { Direct Service Industries ("DSIs") } \\
\text { two aluminum smelters }\end{array}$ & $\begin{array}{l}\text { One aluminum plant owned by Alcoa in } \\
\text { Washington. The other DSI in the region } \\
\text { is a small pulp and paper mill in Port } \\
\text { Townsend, Washington. }\end{array}$ \\
\hline Port districts & 1 & $\begin{array}{c}\text { Direct Service Industries (“DSIs") } \\
\text { Local electric cooperatives provide } \\
\text { power (Umatilla Electric } \\
\text { Cooperative, Columbia Basin } \\
\text { Electric) }\end{array}$ & Port of Morrow (POM) \\
\hline
\end{tabular}




\begin{tabular}{|l|c|c|l|}
\hline \multicolumn{2}{|c|}{ BPA's Customers } & Type of Organization & \multicolumn{1}{c|}{ Organizations } \\
\hline Tribal utilities & 2 & $\begin{array}{c}\text { Publicly Owned Utilities } \\
\text { (These utilities are same as } \\
\text { cooperatives) }\end{array}$ & $\begin{array}{l}\text { Umpqua Indian Utility Coop. } \\
\text { Yakama Power }\end{array}$ \\
\hline Total & 142 & & \\
\hline
\end{tabular}

Focusing on the organizations that are related to BPA, Table 42 shows specific information about missions as presented by each organization:

Table 42: Business Information of the Power Marketing Agencies (PMAs)

\begin{tabular}{|l|l|}
\hline \multicolumn{2}{|c|}{ Bonneville Power Administration (BPA) } \\
\hline $\begin{array}{l}\text { Mission } \\
\text { Statement }\end{array}$ & $\begin{array}{l}\text { "The Bonneville Power Administration's (BPA) mission as a public service organization is } \\
\text { to create and deliver the best value for our customers and constituents as we act in concert } \\
\text { rith oliable power to provide the Pacific Northwest: • An adequate, efficient, economical, and } \\
\text { transmitting power from Federal and non-Federal generating units; providing service to } \\
\text { BPA's customers; providing interregional interconnections; and maintaining electrical } \\
\text { reliability and stability; and - Mitigation of the Federal Columbia River Power System's } \\
\text { impacts on fish and wildlife." }\end{array}$ \\
\hline $\begin{array}{l}\text { Mission } \\
\text { Statement }\end{array}$ & $\begin{array}{l}\text { "SEPA will market and deliver federal hydroelectric power, at the lowest possible cost, to } \\
\text { public bodies and cooperatives in the Southeastern United States." }\end{array}$ \\
\hline \multicolumn{1}{|c|}{ Southwestern Power Administration (SWPA) } \\
\hline $\begin{array}{l}\text { Mission } \\
\text { Statement }\end{array}$ & $\begin{array}{l}\text { "SWPA markets and reliably deliver Federal hydroelectric power with preference to public } \\
\text { bodies and cooperatives. This is accomplished by maximizing the use of Federal assets to } \\
\text { repay the Federal investment and participating with other water resource users in an effort to } \\
\text { balance their diverse interests with power needs within broad parameters set by the U.S. Army } \\
\text { Corps of Engineers (Corps), and implementing public policy." } \\
\text { Western Area Power Administration (WAPA) }\end{array}$ \\
\hline $\begin{array}{l}\text { Mission } \\
\text { Statement }\end{array}$ & $\begin{array}{l}\text { "WAPA's mission is to market and deliver reliable, clean, renewal, reliable, cost-based } \\
\text { federal hydroelectric power and related services within a 15-state region of the central and } \\
\text { western states, delivering electricity generated from 14 multi-use water projects". }\end{array}$ \\
\hline
\end{tabular}
Source:[253]

Below are described the main characteristics of power transmission utilities in the United

States. 


\subsubsection{Power Marketing Agencies (PMAs)}

These organizations market wholesale power having a role in the transmission and electric power system [255], they are essential for the U.S. electricity infrastructure. There are four PMAs in the United States: Bonneville Power Administration (BPA), the Western Area Power Administration (WAPA), the Southeastern Power Administration (SEPA), and the Southwestern Power Administration (SWPA) [256]. FERC is the authority that regulates the electric transmission market, except when the seller is a public agency. Therefore, PMAs and local municipal utilities are exempt from general regulation by FERC [63].

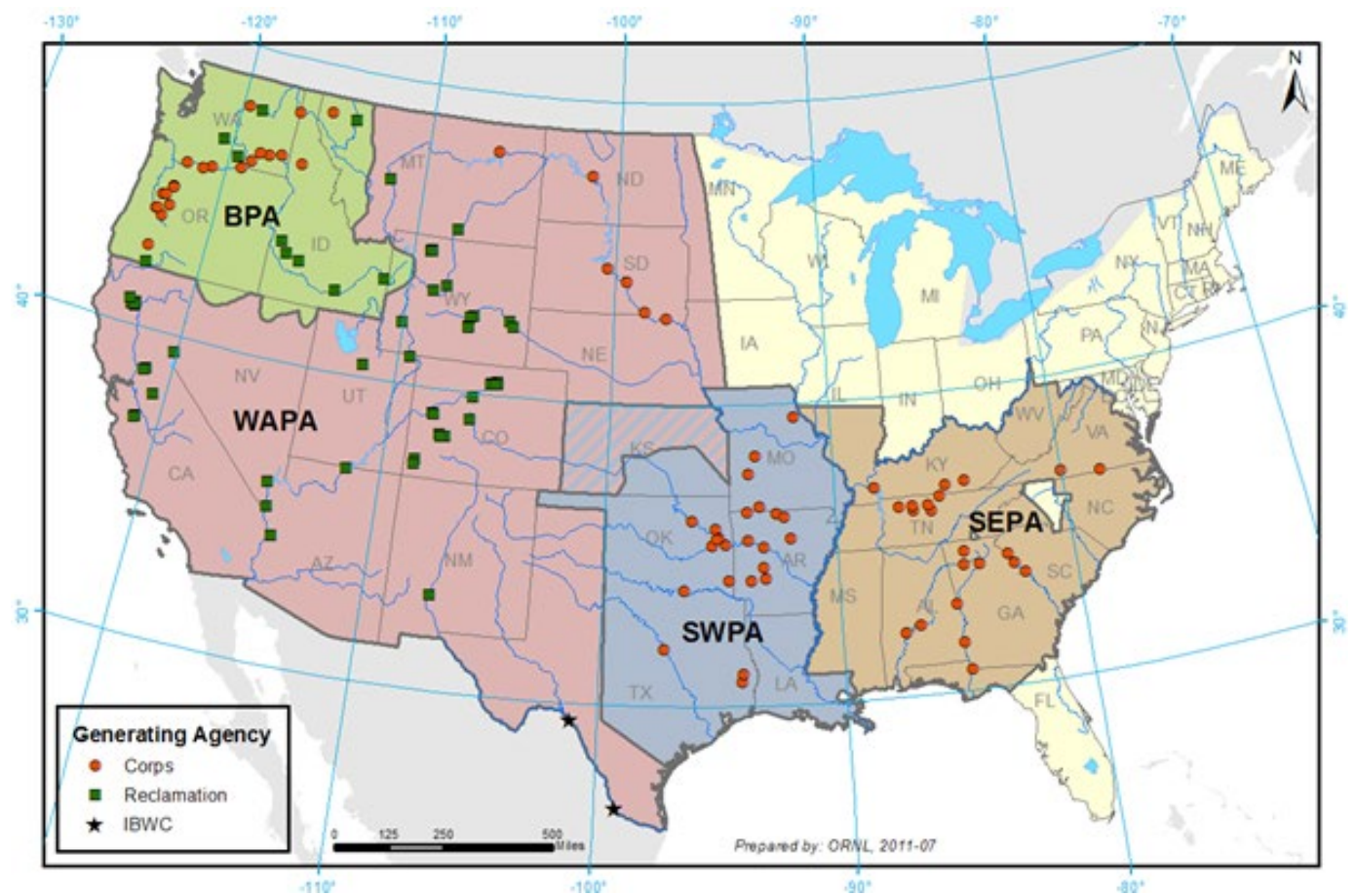

Figure 37: Federal Power Marketing Administration Territories and Facilities Source: [255]

In the particular case of the Northwest, BPA markets the electricity generated by that plant. Additionally, BPA balances the power system, ensuring that electricity supply matches electricity demand at all times [255]. As a part of BPA, the U.S. Army Corps of 
Engineers (USACE) owns and operates hydroelectric power plants in the PMAs' regions. These PMAs do not own power plants [51]. BPA is the only PMA that is self-financing and does not receive tax revenues [58].

\subsubsection{Regional Transmission Organizations and Independent System Operators}

As part of the wholesale power market, the Regional Transmission Organizations (RTOs) and Independent System Operators (ISOs) are part of the wholesale power market, with similar functions as BPA. Both type of organizations has similar roles and were created by recommendations of FERC. ISOs operate and administrate the wholesale electric market, considering reliability standards in the planification of the system. RTOs have the same function as ISOs plus greater responsibilities for the transmission networks. Therefore, RTOs coordinate, control, and monitor electric power system operations. Both of them, RTOs and ISOs, are part of the regional planning to ensure to meet the appropriate infrastructure for reliability aspects [51].

There are currently seven ISOs in the United States [51]:

- CAISO (California ISO),

- NYISO (New York ISO),

- ERCOT (Electric Reliability Council of Texas, also a Regional Reliability Council),

- MISO (Midcontinent Independent System Operator),

- ISO-NE (ISO New England),

- AESO (Alberta Electric System Operator), 
- IESO (Independent Electricity System Operator)

There are currently 4 RTOs in the U.S. [51]:

- PJM (PJM Interconnection)

- MISO (Midcontinent Independent System Operator); also, an RTO

- SPP (Southwest Power Pool); also, a Regional Reliability Council

ISONE (ISO New England); also, an RTO

\subsection{R\&D Project Alternatives}

\subsubsection{Identification of R\&D Projects to be Evaluated}

The R\&D projects to be evaluated at BPA for this application case have the common objective to focus on increasing the reliability and stability of the high voltage power transmission system. The projects emphasize the monitoring systems and prevention of the effects of natural disasters or malfunction of the stability of the system.

The R\&D projects at BPA are categorized in the following "asset categories":

1- Transmission Services

2 - Federal Hydro

3 - Facilities

4 - IT

5 - Corporate Sponsored

6 - Other 
As stated above, for this specific application case, the selected projects follow in the category of Transmission Service. Therefore, the characteristics of the R\&D selected projects are:

- Focused on increasing the reliability and stability of the high-power transmission system.

- The projects emphasize the monitoring systems and prevention of the effects of natural disasters or malfunction of the stability of the system.

- The duration of the projects is more than 12 months.

- $\quad$ Projects focusing on Transmission - transformers and lines.

Since the number of projects to be evaluated is high and the variety of characteristics of the projects, even in the same transmission service category, a more effective analysis can be done clustering the projects.

Homogeneity of the elements needs to be compared. Using the AHP or HDM, the experts can provide judgments when they are comparable [257]. Therefore, Saaty considers clustering and homogeneity conditions to compare the elements. Below is presented the development of clustering the R\&D projects to be used in the application case.

\section{Clustering the R\&D Projects}

The variables considered for clustering are the following:

\section{- Derivable of the project}

- Documents 
- Software/Design/Data

- Hardware/Software/Document

\section{- Impact on System component}

- Generation

- TX Line

- Transformer

- Load

- All

- Impact on System Function

- Power system modeling

- Improve the economic efficiency - modeling

- Increase the Reliability of the system

- Increase the capacity with less cost (efficiency) with hardware

- Power system performance (TECHNICAL) (the system will work smoothly - a mix of technical and economic)

- Improve the Environmental conditions

- All

- Collaborative

- No

- Yes

The results of clustering the R\&D project alternatives are shown below. The selected cluster has 4 R\&D projects (TIP-Technology Innovation Projects at BPA). 


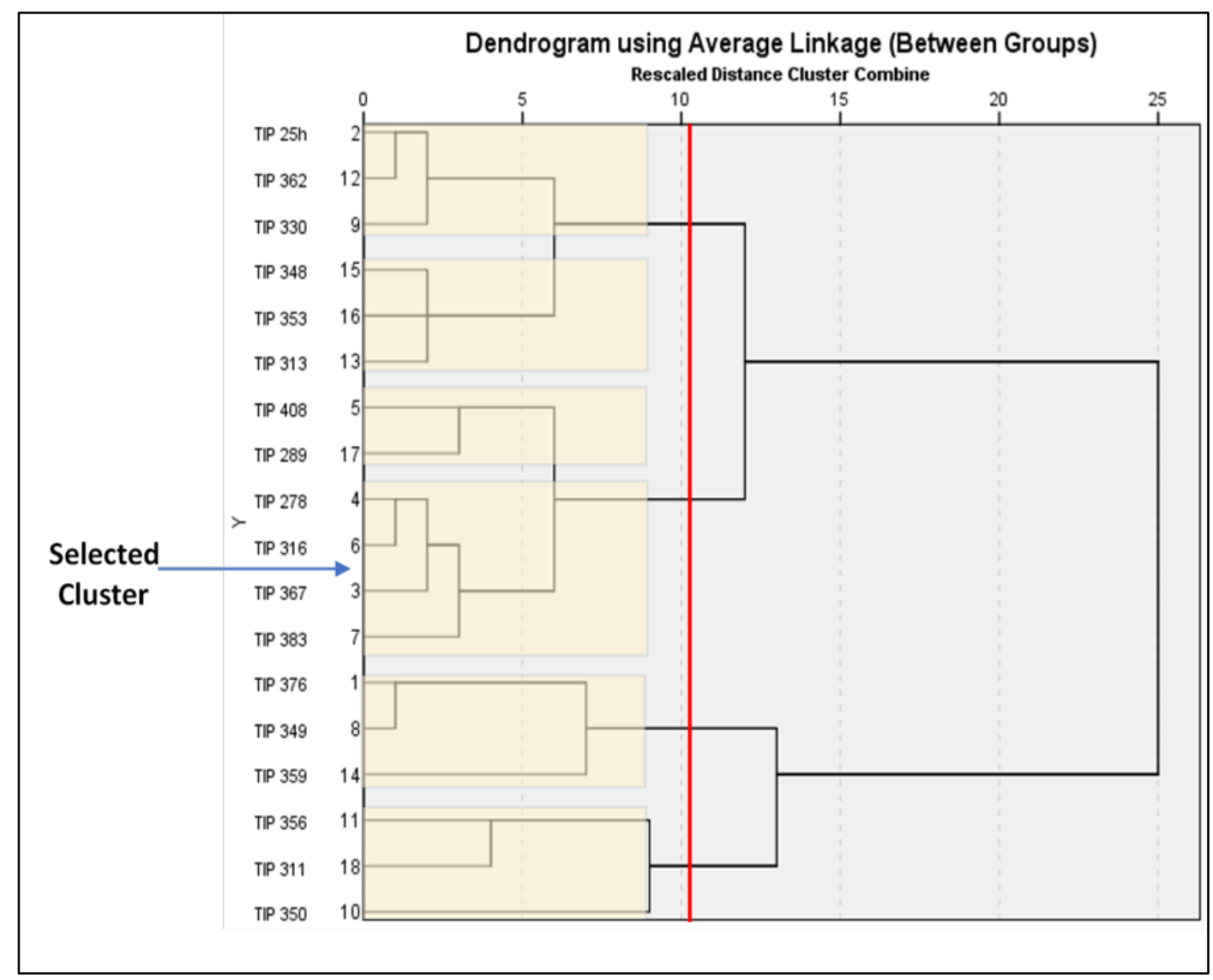

Figure 38: R\&D Project Clusters - Results

*TIP: R\&D Project at BPA - Technology Innovation Office 
Table 43: R\&D Projects Selected Cluster - Results of Cluster Analysis

\begin{tabular}{|c|c|c|}
\hline TIP* & Project Title & Description \\
\hline $\begin{array}{l}\text { TIP } \\
316\end{array}$ & $\begin{array}{l}\text { Combined Horizontal- } \\
\text { Vertical Seismic Isolation } \\
\text { System for HighVoltage } \\
\text { Power Transformer }\end{array}$ & $\begin{array}{l}\text { This project researches to develop and demonstrate the effectiveness } \\
\text { of a practical 3- dimensional seismic isolation system for use with } \\
\text { high-voltage power transformers. }\end{array}$ \\
\hline $\begin{array}{l}\text { TIP } \\
367\end{array}$ & $\begin{array}{l}\text { EPRI P37: Power } \\
\text { Transformer Through- } \\
\text { fault Risk Assessment }\end{array}$ & $\begin{array}{l}\text { The project approaches the power transformer as a system of major } \\
\text { subcomponents, including the main body, load tap changer, } \\
\text { dielectric fluid, bushings, cooling, and other auxiliaries. } \\
\text { Transformers are designed to withstand certain levels of stress such } \\
\text { as number of through-faults, fault } \\
\text { magnitude, and duration. Over time, as the transformer experiences } \\
\text { through-faults, the resulting stress impacts the transformer's future } \\
\text { survivability }\end{array}$ \\
\hline $\begin{array}{l}\text { TIP } \\
278\end{array}$ & $\begin{array}{l}\text { Transformer Bushing } \\
\text { Performance }\end{array}$ & 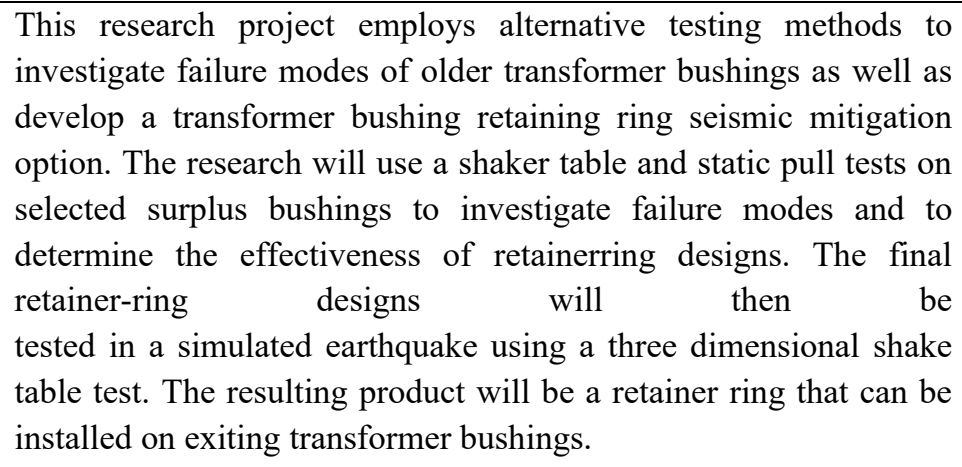 \\
\hline $\begin{array}{l}\text { TIP } \\
383\end{array}$ & $\begin{array}{l}\text { Unmanned Aircraft } \\
\text { Systems Power } \\
\text { Equipment Inspections: } \\
\text { Optimizing Workflows } \\
\text { and Automation Tools }\end{array}$ & $\begin{array}{l}\text { This project will be performed in three stages. First, the research } \\
\text { team will determine the optimal flight mission plans and platforms } \\
\text { for inspecting and monitoring transmission lines, conductors, } \\
\text { towers, abstations. } \\
\text { Second, using visible and near-infrared (VNIR) multispectral } \\
\text { imagery and thermal infrared (TIR) imagery, the team will develop } \\
\text { a workflow for identifying encroaching vegetation hazards based on } \\
\text { estimates of the proximity and potential for vegetation growth in } \\
\text { critical } \\
\text { areas. } \\
\text { Third, the team will develop tools for assessing thermal conditions } \\
\text { of power system equipment such as circuit breakers and } \\
\text { transformers within a substation using the TIR imagery collected } \\
\text { from a UAS. Temperature monitoring by infrared inspection using } \\
\text { both rotary and fixed-wing UAS platforms may provide an efficient } \\
\text { and inexpensive assessment of the condition of the connectors and } \\
\text { isolators. }\end{array}$ \\
\hline
\end{tabular}

Source: Bonneville Power Administration Website. Technology Innovation Office [254] 
After identifying the clusters and the R\&D projects (TIPs), the final model is described in Figure 39. The model described has 4 levels, including the R\&D project alternatives.

Table 44: Information about the R\&D Project Alternatives to be Evaluated

\begin{tabular}{|c|c|c|c|c|}
\hline & TIP 316 & TIP 367 & $\begin{array}{l}\text { TIP } 278 \\
\end{array}$ & TIP 383 \\
\hline & $\begin{array}{c}\text { ALTERNATIVE } \\
1\end{array}$ & ALTERNATIVE 2 & ALTERNATIVE 3 & $\begin{array}{c}\text { ALTERNATIVE } \\
4\end{array}$ \\
\hline & $\begin{array}{c}\text { Combined } \\
\text { Horizontal- } \\
\text { Vertical Seismic } \\
\text { Isolation System } \\
\text { for High Voltage } \\
\text { Power } \\
\text { Transformer } \\
\end{array}$ & $\begin{array}{c}\text { Power } \\
\text { Transformer } \\
\text { Through-fault Risk } \\
\text { Assessment }\end{array}$ & $\begin{array}{l}\text { Transformer } \\
\text { Bushing } \\
\text { Performance }\end{array}$ & $\begin{array}{c}\text { Unmanned Aircraft } \\
\text { Systems Power } \\
\text { Equipment } \\
\text { Inspections: } \\
\text { Optimizing } \\
\text { Workflows and } \\
\text { Automation Tools } \\
\end{array}$ \\
\hline Description & $\begin{array}{l}\text { Description: } \\
\text { High-Voltage } \\
\text { Power } \\
\text { Transformers are } \\
\text { seismically } \\
\text { vulnerable. Seismic } \\
\text { base isolation } \\
\text { systems only } \\
\text { provide protection } \\
\text { against the } \\
\text { horizontal } \\
\text { components of } \\
\text { earthquake motion. } \\
\text { This project } \\
\text { conducts research } \\
\text { to develop and } \\
\text { demonstrate the } \\
\text { effectiveness of a } \\
\text { practical 3- } \\
\text { dimensional } \\
\text { seismic isolation } \\
\text { system. Analytical } \\
\text { models of the tested } \\
\text { system will be } \\
\text { developed to } \\
\text { compare results to } \\
\text { the experimental } \\
\text { data, thus validating } \\
\text { the models. }\end{array}$ & $\begin{array}{l}\text { Description: } \\
\text { Over time as the } \\
\text { transformer } \\
\text { experiences multiple } \\
\text { through-fault events, } \\
\text { the resulting stress } \\
\text { impacts the } \\
\text { transformer's } \\
\text { survivability. The } \\
\text { project approaches } \\
\text { the power } \\
\text { transformer as a } \\
\text { system } \\
\text { subcomponents: } \\
\text { main body, load tap } \\
\text { changer, dielectric } \\
\text { fluid, bushings, } \\
\text { cooling, and other } \\
\text { auxiliaries. } \\
\text { The project will } \\
\text { generate data, a } \\
\text { methodology, } \\
\text { algorithms related to } \\
\text { transformers' } \\
\text { applications and } \\
\text { operations. } \\
\text { Considerations and } \\
\text { apply algorithms } \\
\text { with utility data and } \\
\text { review results. } \\
\text { Objectives } \\
\text { To develop a new } \\
\text { methodology to }\end{array}$ & $\begin{array}{l}\text { Description: } \\
\text { Porcelain bushings, } \\
\text { on top of the } \\
\text { transformer, are } \\
\text { susceptible to failure } \\
\text { during earthquakes. } \\
\text { This research } \\
\text { project employs } \\
\text { alternative testing } \\
\text { methods to } \\
\text { investigate failure } \\
\text { modes of older } \\
\text { transformer } \\
\text { bushings as well as } \\
\text { develop a } \\
\text { transformer bushing } \\
\text { retaining ring } \\
\text { seismic mitigation } \\
\text { option. The research } \\
\text { will use a shaker } \\
\text { table and static pull } \\
\text { tests to investigate } \\
\text { failure modes and to } \\
\text { determine the } \\
\text { effectiveness of } \\
\text { retainerring designs. } \\
\text { The final retainer- } \\
\text { ring designs will } \\
\text { then be tested in a } \\
\text { simulated } \\
\text { earthquake using a } \\
\text { three dimensional } \\
\text { shake table test. }\end{array}$ & $\begin{array}{l}\text { Description: } \\
\text { Unmanned aircraft } \\
\text { systems (UAS) for } \\
\text { inspecting and } \\
\text { monitoring } \\
\text { substations, towers, } \\
\text { and transmission lines } \\
\text { can provide high- } \\
\text { quality remote sensing } \\
\text { data quickly, safely, } \\
\text { and economically. } \\
\text { This project will be } \\
\text { performed in } \\
\text { determining the } \\
\text { optimal flight mission } \\
\text { plans and platforms } \\
\text { for inspecting and } \\
\text { monitoring } \\
\text { transmission lines, } \\
\text { conductors, towers, } \\
\text { and substations. Using } \\
\text { visible and near- } \\
\text { infrared (VNIR) } \\
\text { multispectral imagery } \\
\text { and thermal infrared } \\
\text { (TIR) imagery, it will } \\
\text { be developed a } \\
\text { workflow for } \\
\text { identifying } \\
\text { encroaching } \\
\text { vegetation hazards. It } \\
\text { will develop tools for } \\
\text { assessing the thermal }\end{array}$ \\
\hline
\end{tabular}




\begin{tabular}{|c|c|c|c|c|}
\hline & TIP 316 & TIP 367 & TIP 278 & TIP 383 \\
\hline & $\begin{array}{c}\text { ALTERNATIVE } \\
1 \\
\end{array}$ & ALTERNATIVE 2 & ALTERNATIVE 3 & $\begin{array}{c}\text { ALTERNATIVE } \\
\mathbf{4} \\
\end{array}$ \\
\hline & $\begin{array}{c}\text { Combined } \\
\text { Horizontal- } \\
\text { Vertical Seismic } \\
\text { Isolation System } \\
\text { for HighVoltage } \\
\text { Power } \\
\text { Transformer } \\
\end{array}$ & $\begin{array}{c}\text { Power } \\
\text { Transformer } \\
\text { Through-fault Risk } \\
\text { Assessment }\end{array}$ & $\begin{array}{l}\text { Transformer } \\
\text { Bushing } \\
\text { Performance }\end{array}$ & $\begin{array}{c}\text { Unmanned Aircraft } \\
\text { Systems Power } \\
\text { Equipment } \\
\text { Inspections: } \\
\text { Optimizing } \\
\text { Workflows and } \\
\text { Automation Tools }\end{array}$ \\
\hline & $\begin{array}{l}\text { horizontal and } \\
\text { vertical acceleration } \\
\text { isolation system } \\
\text { that provides a } \\
\text { significant } \\
\text { reduction in the } \\
\text { earthquake input } \\
\text { motions (horizontal } \\
\text { and vertical) to the } \\
\text { high-voltage } \\
\text { transformer for both } \\
\text { retrofit and new } \\
\text { installations } \\
\text { Derivable: } \\
\text { Documents: } \\
\text { Reports of } \\
\text { mitigation options, } \\
\text { analysis and } \\
\text { preliminary and } \\
\text { final testing of } \\
\text { selected options. } \\
\text { Investment level } \\
\text { (US \$) = 948,000 } \\
\text { Time spam } \\
\text { (months) = 59 }\end{array}$ & $\begin{array}{l}\text { assess the } \\
\text { susceptibility of a } \\
\text { power transformer to } \\
\text { a through-fault } \\
\text { failure. The goal is } \\
\text { to understand the } \\
\text { impact as function of } \\
\text { number of through } \\
\text { faults, fault } \\
\text { magnitude and } \\
\text { duration using } \\
\text { readily available } \\
\text { data and use results } \\
\text { in utility transformer } \\
\text { replacement } \\
\text { strategy. } \\
\text { Derivable: Software } \\
\text { / Design / Data: } \\
\text { A report } \\
\text { documenting the } \\
\text { underlying } \\
\text { methodology, data, } \\
\text { algorithm, } \\
\text { approaches. } \\
\text { Investment level } \\
\text { (US \$) = 22,500 } \\
\text { Time spam } \\
\text { (months) = 38 }\end{array}$ & $\begin{array}{l}\text { Objectives } \\
\text { To develop a } \\
\text { seismic mitigation } \\
\text { option for high- } \\
\text { voltage power } \\
\text { transformer } \\
\text { bushings as well as } \\
\text { improve testing } \\
\text { methods and } \\
\text { qualification } \\
\text { procedures. } \\
\text { Derivable: } \\
\text { Documents: } \\
\text { Reports about the } \\
\text { retainer ring that can } \\
\text { be installed on } \\
\text { exiting transformer } \\
\text { bushings, performed } \\
\text { tests, data of testing, } \\
\text { and internal core } \\
\text { vibration effects. } \\
\text { Investment level } \\
\text { (US \$) = 200,147 } \\
\text { Time spam } \\
\text { (months) = } 25\end{array}$ & $\begin{array}{l}\text { conditions of power } \\
\text { system equipment. } \\
\text { Objectives } \\
\text { To determine optimal } \\
\text { flight mission plans } \\
\text { and sensor } \\
\text { configurations, and to } \\
\text { develop automated } \\
\text { workflows that will } \\
\text { advance the } \\
\text { Technology Readiness } \\
\text { Level (TRL) of UAS } \\
\text { inspection, } \\
\text { monitoring, and } \\
\text { mapping of } \\
\text { transmission towers, } \\
\text { lines, and substations. } \\
\text { Derivable: Software / } \\
\text { Design / Data: } \\
\text { Reports about } \\
\text { literature review, } \\
\text { results of the test } \\
\text { flights, } \\
\text { algorithms/procedures } \\
\text { for vegetation } \\
\text { encroachment, flight } \\
\text { planning and } \\
\text { processing for wildlife } \\
\text { management. } \\
\text { Investment level (US } \\
\text { \$) = 1,125,000 } \\
\text { Time spam (months) } \\
=35 \\
\end{array}$ \\
\hline $\begin{array}{l}\text { Derivable of } \\
\text { the project }\end{array}$ & $\begin{array}{l}\text { Derivable: } \\
\text { Documents: } \\
\text { Reports of } \\
\text { mitigation options, } \\
\text { analysis and } \\
\text { preliminary and } \\
\text { final testing of } \\
\text { selected options. }\end{array}$ & $\begin{array}{l}\text { Derivable: Software } \\
\text { / Design / Data: } \\
\text { A report } \\
\text { documenting the } \\
\text { underlying } \\
\text { methodology, data, } \\
\text { algorithm, } \\
\text { approaches. }\end{array}$ & $\begin{array}{l}\text { Derivable: } \\
\text { Documents: } \\
\text { Reports about the } \\
\text { retainer ring that can } \\
\text { be installed on } \\
\text { exiting transformer } \\
\text { bushings, performed } \\
\text { tests, data of testing, }\end{array}$ & $\begin{array}{l}\text { Derivable: Software / } \\
\text { Design / Data: } \\
\text { Reports about } \\
\text { literature review, } \\
\text { results of the test } \\
\text { flights, } \\
\text { algorithms/procedures } \\
\text { for vegetation } \\
\text { encroachment, flight }\end{array}$ \\
\hline
\end{tabular}




\begin{tabular}{|c|c|c|c|c|}
\hline & TIP 316 & TIP 367 & TIP 278 & TIP 383 \\
\hline & $\begin{array}{c}\text { ALTERNATIVE } \\
1\end{array}$ & ALTERNATIVE 2 & ALTERNATIVE 3 & $\begin{array}{c}\text { ALTERNATIVE } \\
4\end{array}$ \\
\hline & $\begin{array}{c}\text { Combined } \\
\text { Horizontal- } \\
\text { Vertical Seismic } \\
\text { Isolation System } \\
\text { for HighVoltage } \\
\text { Power } \\
\text { Transformer } \\
\end{array}$ & $\begin{array}{c}\text { Power } \\
\text { Transformer } \\
\text { Through-fault Risk } \\
\text { Assessment }\end{array}$ & $\begin{array}{l}\text { Transformer } \\
\text { Bushing } \\
\text { Performance }\end{array}$ & $\begin{array}{c}\text { Unmanned Aircraft } \\
\text { Systems Power } \\
\text { Equipment } \\
\text { Inspections: } \\
\text { Optimizing } \\
\text { Workflows and } \\
\text { Automation Tools } \\
\end{array}$ \\
\hline & & & $\begin{array}{l}\text { and internal core } \\
\text { vibration effects. }\end{array}$ & $\begin{array}{l}\text { planning and } \\
\text { processing for wildlife } \\
\text { management. }\end{array}$ \\
\hline $\begin{array}{l}\text { Investment } \\
\text { level (US \$) }\end{array}$ & $\begin{array}{l}\text { Investment level } \\
(\text { US \$ })=948,000\end{array}$ & $\begin{array}{l}\text { Investment level } \\
(\text { US \$ })=22,500\end{array}$ & $\begin{array}{l}\text { Investment level } \\
(\text { US \$) }=200,147\end{array}$ & $\begin{array}{l}\text { Investment level (US } \\
\$ \text { ) }=1,125,000\end{array}$ \\
\hline $\begin{array}{l}\text { Time spam } \\
\text { (months) }\end{array}$ & $\begin{array}{l}\text { Time spam } \\
(\text { months })=59\end{array}$ & $\begin{array}{l}\text { Time spam } \\
(\text { months })=38\end{array}$ & $\begin{array}{l}\text { Time spam } \\
(\text { months })=25\end{array}$ & $\begin{array}{l}\text { Time spam (months) } \\
=35\end{array}$ \\
\hline $\begin{array}{l}\text { Impact on } \\
\text { System } \\
\text { component }\end{array}$ & Transformer & Transformer & Transformer & $\begin{array}{l}\text { Transmission Line, } \\
\text { tower, transformer }\end{array}$ \\
\hline $\begin{array}{l}\text { Impact on } \\
\text { System } \\
\text { Function } \\
\end{array}$ & $\begin{array}{l}\text { Increase the } \\
\text { Reliability of the } \\
\text { system }\end{array}$ & $\begin{array}{l}\text { Increase the } \\
\text { Reliability of the } \\
\text { system }\end{array}$ & $\begin{array}{l}\text { Increase the } \\
\text { Reliability of the } \\
\text { system }\end{array}$ & $\begin{array}{l}\text { Increase the Reliability } \\
\text { of the system }\end{array}$ \\
\hline Collaborative & No & Yes & No & No \\
\hline $\begin{array}{l}\text { Asset } \\
\text { Category }\end{array}$ & Transmission & Transmission & Transmission & Transmission \\
\hline
\end{tabular}

Source: [254] 


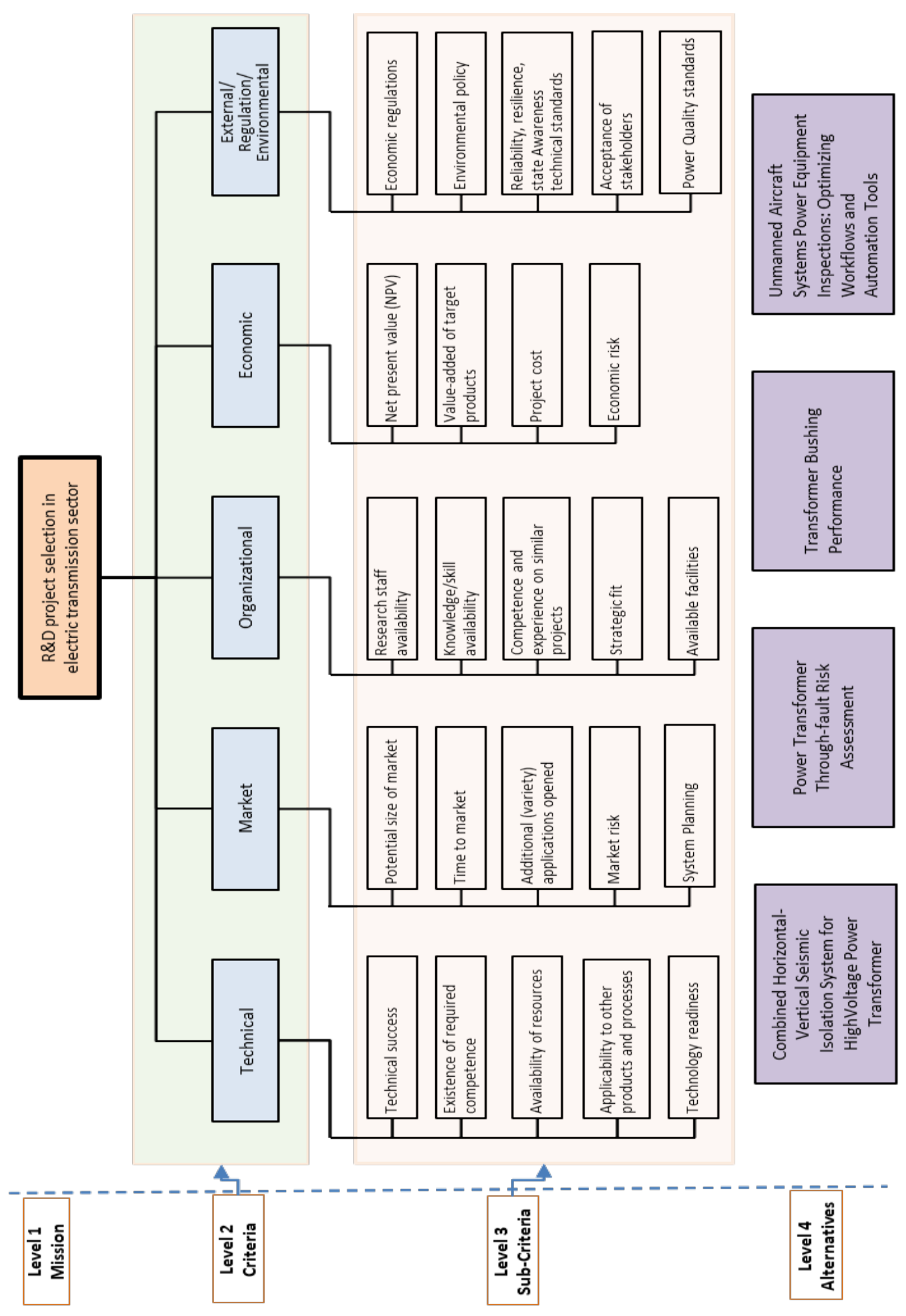

Figure 39: Final Validated HDM Model 


\subsection{Alternatives Quantification Results}

Expert Panel EP2 evaluated the relative importance of alternatives with respect to each of the twenty-four sub-criteria. The arithmetic means of experts' judgments for the relative importance of considered alternatives are shown below.

\section{Results of Alternatives with Respect to Technical Success Sub-criterion}

Expert panel EP2 evaluated the relative importance of alternatives with respect to the Technical Success sub-criterion using the research instrument RI4. The arithmetic means of experts' judgments for the relative importance of considered alternatives are shown in Table 45 and Figure 40 below.

Table 45: Relative Importance of Alternatives Respect to Technical Success Sub-criterion

\begin{tabular}{|c|c|c|c|c|c|}
\hline & Alternative 1 & Alternative 2 & Alternative 3 & Alternative 4 & \\
\hline $\begin{array}{l}\text { Technical } \\
\text { Success }\end{array}$ & $\begin{array}{c}\text { Combined } \\
\text { Horizontal- } \\
\text { Vertical } \\
\text { Seismic } \\
\text { Isolation } \\
\text { System for } \\
\text { High Voltage } \\
\text { Power } \\
\text { Transformer }\end{array}$ & $\begin{array}{c}\text { Power } \\
\text { Transformer } \\
\text { Through-fault } \\
\text { Risk } \\
\text { Assessment }\end{array}$ & $\begin{array}{l}\text { Transformer } \\
\text { Bushing } \\
\text { Performance }\end{array}$ & $\begin{array}{c}\text { Unmanned } \\
\text { Aircraft } \\
\text { Systems } \\
\text { Power } \\
\text { Equipment } \\
\text { Inspections: } \\
\text { Optimizing } \\
\text { Workflows } \\
\text { and } \\
\text { Automation } \\
\text { Tools }\end{array}$ & Inconsistency \\
\hline Expert 16 & 0.32 & 0.38 & 0.1 & 0.2 & 0.02 \\
\hline Expert 25 & 0.34 & 0.45 & 0.07 & 0.15 & 0.08 \\
\hline Expert 28 & 0.22 & 0.33 & 0.2 & 0.25 & 0 \\
\hline Expert 27 & 0.36 & 0.14 & 0.37 & 0.13 & 0.07 \\
\hline Expert 5 & 0.15 & 0.31 & 0.12 & 0.43 & 0.06 \\
\hline Expert 4 & 0.25 & 0.25 & 0.25 & 0.25 & 0 \\
\hline Expert 15 & 0.47 & 0.32 & 0.14 & 0.07 & 0.06 \\
\hline Mean & 0.3 & 0.31 & 0.18 & 0.21 & \\
\hline Minimum & 0.15 & 0.14 & 0.07 & 0.07 & \\
\hline Maximum & 0.47 & 0.45 & 0.37 & 0.43 & \\
\hline $\begin{array}{c}\text { Std. } \\
\text { Deviation }\end{array}$ & 0.1 & 0.09 & 0.1 & 0.11 & \\
\hline Disagreement & & & & & 0.091 \\
\hline
\end{tabular}




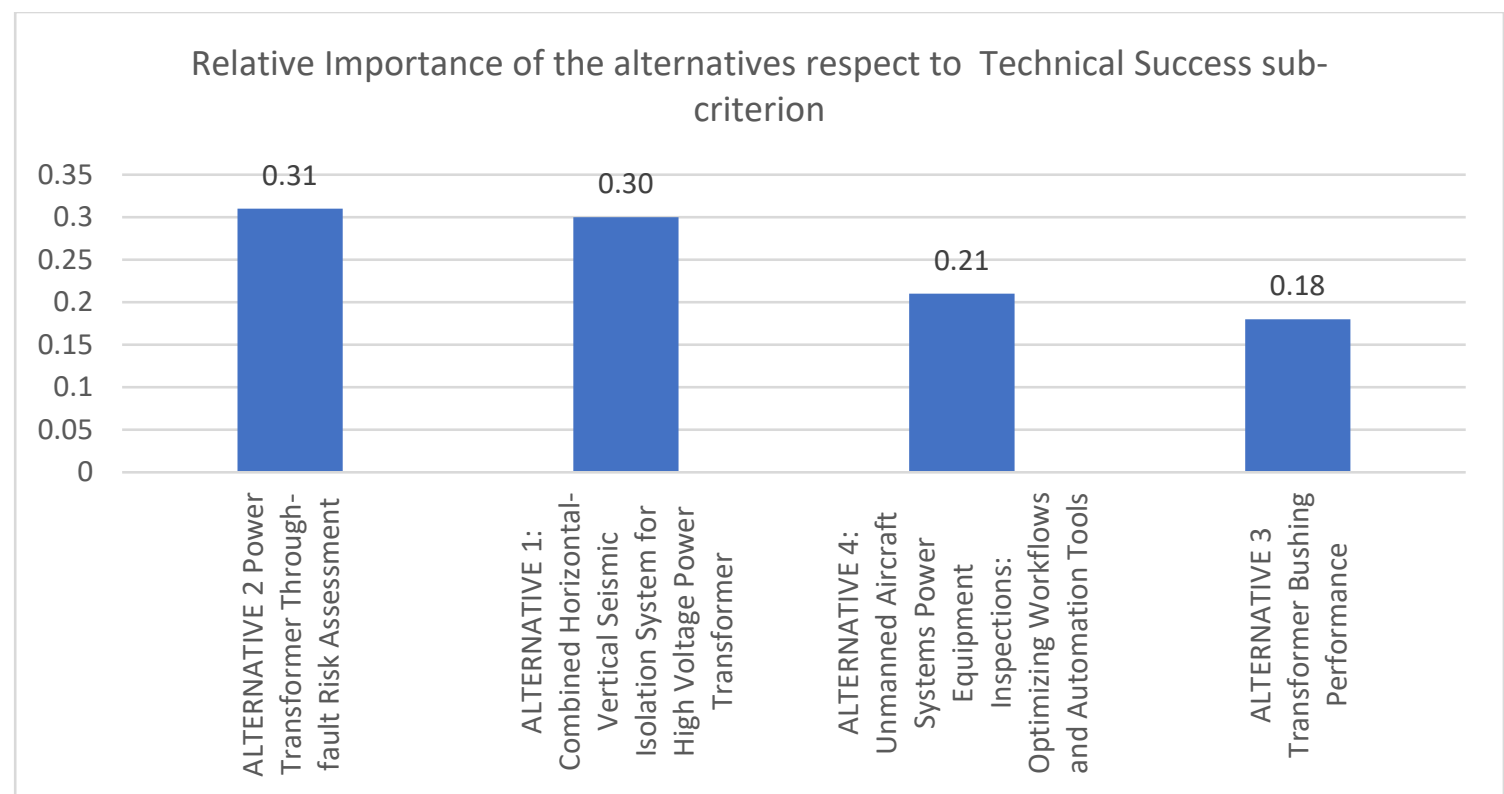

Figure 40: Relative Importance of Alternatives Respect to Technical Success Sub-criterion

According to the results, Alternative 2 scored the most important (23\%) with respect to the Technical Success sub-criterion. Alternative 1, Alternative 4, and Alternative 3 followed in importance $(30 \%, 21 \%$, and $18 \%$, respectively).

The inconsistency level within each expert is acceptable $($ all $<0.10)$. There is also no significant level of disagreement among experts (0.091).

\section{Results of Alternatives with Respect to the Existence of Required Competence Sub- criterion}

Expert panel EP2 evaluated the relative importance of alternatives with respect to the Existence of Required Competence sub-criterion using the research instrument RI4. The arithmetic means of experts' judgments for the relative importance of considered alternatives are shown in Table 46. 
Table 46: Relative Importance of Alternatives Respect to Existence of Required Competence Sub-criterion

\begin{tabular}{|c|c|c|c|c|c|}
\hline & Alternative 1 & Alternative 2 & Alternative 3 & Alternative 4 & \\
\hline $\begin{array}{l}\text { Existence of } \\
\text { Required } \\
\text { Competence }\end{array}$ & $\begin{array}{c}\text { Combined } \\
\text { Horizontal- } \\
\text { Vertical } \\
\text { Seismic } \\
\text { Isolation } \\
\text { System for } \\
\text { High Voltage } \\
\text { Power } \\
\text { Transformer }\end{array}$ & $\begin{array}{c}\text { Power } \\
\text { Transformer } \\
\text { Through-fault } \\
\text { Risk } \\
\text { Assessment }\end{array}$ & $\begin{array}{l}\text { Transformer } \\
\text { Bushing } \\
\text { Performance }\end{array}$ & $\begin{array}{c}\text { Unmanned } \\
\text { Aircraft } \\
\text { Systems } \\
\text { Power } \\
\text { Equipment } \\
\text { Inspections: } \\
\text { Optimizing } \\
\text { Workflows } \\
\text { and } \\
\text { Automation } \\
\text { Tools }\end{array}$ & Inconsistency \\
\hline Expert 16 & 0.33 & 0.43 & 0.11 & 0.14 & 0.01 \\
\hline Expert 25 & 0.67 & 0.16 & 0.12 & 0.05 & 0.05 \\
\hline Expert 28 & 0.24 & 0.31 & 0.23 & 0.22 & 0.00 \\
\hline Expert 27 & 0.35 & 0.25 & 0.24 & 0.16 & 0.03 \\
\hline Expert 5 & 0.08 & 0.24 & 0.30 & 0.38 & 0.02 \\
\hline Expert 4 & 0.25 & 0.25 & 0.25 & 0.25 & 0.00 \\
\hline Expert 15 & 0.25 & 0.24 & 0.41 & 0.10 & 0.04 \\
\hline Mean & 0.31 & 0.27 & 0.24 & 0.19 & \\
\hline Minimum & 0.08 & 0.16 & 0.11 & 0.05 & \\
\hline Maximum & 0.67 & 0.43 & 0.41 & 0.38 & \\
\hline $\begin{array}{l}\text { Std. } \\
\text { Deviation }\end{array}$ & 0.17 & 0.08 & 0.10 & 0.10 & \\
\hline Disagreement & & & & & 0.098 \\
\hline
\end{tabular}

According to the results, Alternative 1 scored the most important (31\%) with respect to the Existence of Required Competence sub-criterion. Alternative 2, Alternative 3 , and Alternative 4 followed in importance (27\%, 24\%, and 19\%, respectively).

The inconsistency within each expert is acceptable $($ all $<0.10)$. There is also no significant level of disagreement among experts (0.098). 


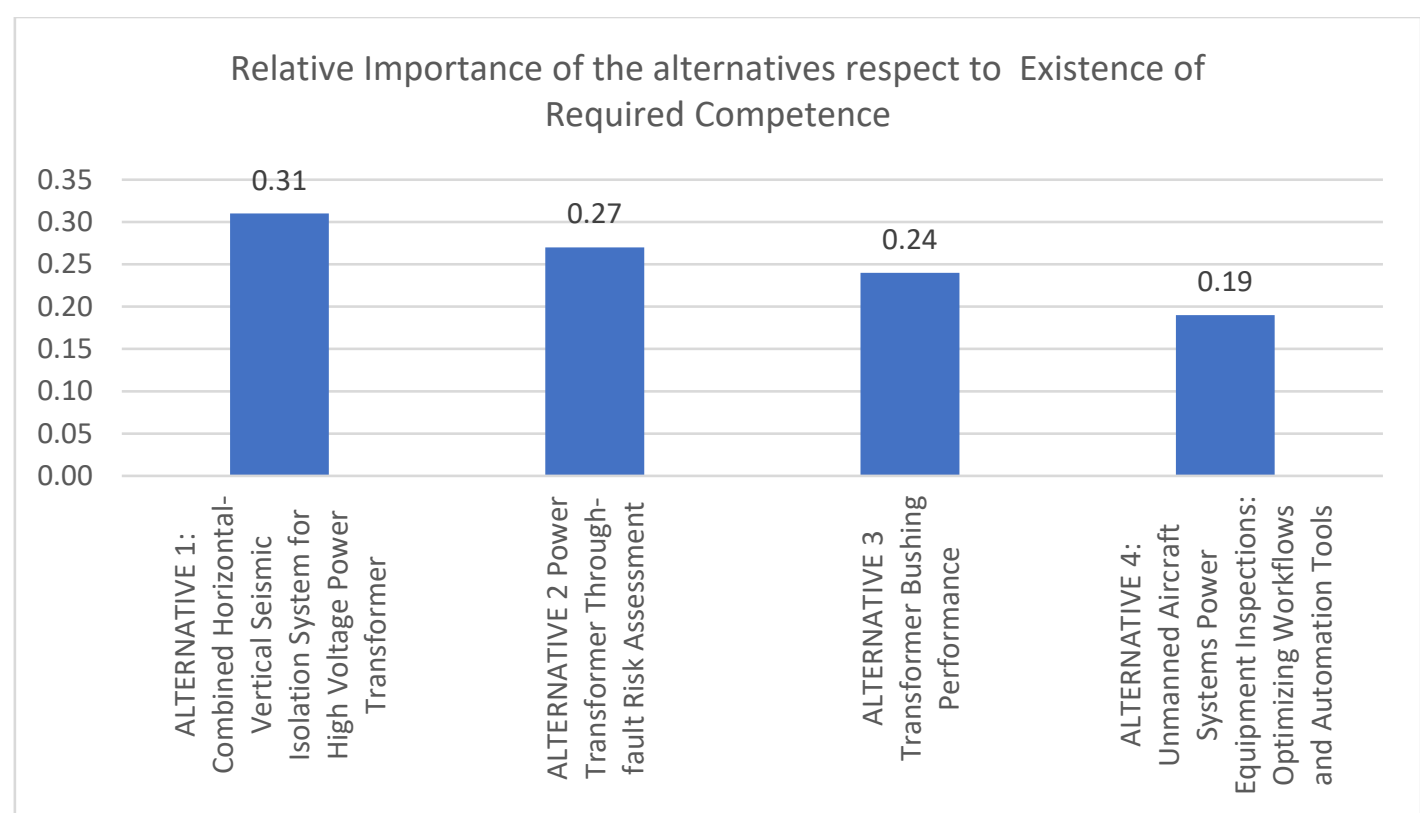

Figure 41: Relative Importance of Alternatives Respect to Existence of Required Competence Sub-criterion

\section{Results of Alternatives with Respect to Availability of Resources Sub-criterion}

Expert panel EP2 evaluated the relative importance of alternatives with respect to the Availability of Resources sub-criterion using the research instrument RI4. The arithmetic means of experts' judgments for the relative importance of considered alternatives are shown in Table 47 and Figure 42 below. 
Table 47: Relative Importance of Alternatives Respect to Availability of Resources Sub-criterion

\begin{tabular}{|c|c|c|c|c|c|}
\hline & Alternative 1 & Alternative 2 & Alternative 3 & Alternative 4 & \\
\hline $\begin{array}{l}\text { Availability } \\
\text { of Resources }\end{array}$ & $\begin{array}{c}\text { Combined } \\
\text { Horizontal- } \\
\text { Vertical } \\
\text { Seismic } \\
\text { Isolation } \\
\text { System for } \\
\text { High Voltage } \\
\text { Power } \\
\text { Transformer }\end{array}$ & $\begin{array}{c}\text { Power } \\
\text { Transformer } \\
\text { Through- } \\
\text { fault Risk } \\
\text { Assessment }\end{array}$ & $\begin{array}{l}\text { Transformer } \\
\text { Bushing } \\
\text { Performance }\end{array}$ & $\begin{array}{c}\text { Unmanned } \\
\text { Aircraft } \\
\text { Systems Power } \\
\text { Equipment } \\
\text { Inspections: } \\
\text { Optimizing } \\
\text { Workflows } \\
\text { and } \\
\text { Automation } \\
\text { Tools }\end{array}$ & Inconsistency \\
\hline Expert 16 & 0.36 & 0.42 & 0.11 & 0.12 & 0.02 \\
\hline Expert 25 & 0.22 & 0.50 & 0.15 & 0.12 & 0.07 \\
\hline Expert 28 & 0.20 & 0.27 & 0.25 & 0.27 & 0.03 \\
\hline Expert 27 & 0.25 & 0.33 & 0.27 & 0.16 & 0.02 \\
\hline Expert 5 & 0.15 & 0.19 & 0.26 & 0.40 & 0.00 \\
\hline Expert 4 & 0.25 & 0.25 & 0.25 & 0.25 & 0.00 \\
\hline Expert 15 & 0.13 & 0.40 & 0.40 & 0.07 & 0.03 \\
\hline Mean & 0.22 & 0.34 & 0.24 & 0.20 & \\
\hline Minimum & 0.13 & 0.19 & 0.11 & 0.07 & \\
\hline Maximum & 0.36 & 0.50 & 0.40 & 0.40 & \\
\hline Std. Deviation & 0.07 & 0.10 & 0.09 & 0.11 & \\
\hline Disagreement & & & & & 0.084 \\
\hline
\end{tabular}

Relative Importance of the alternatives respect to Availability of Resources

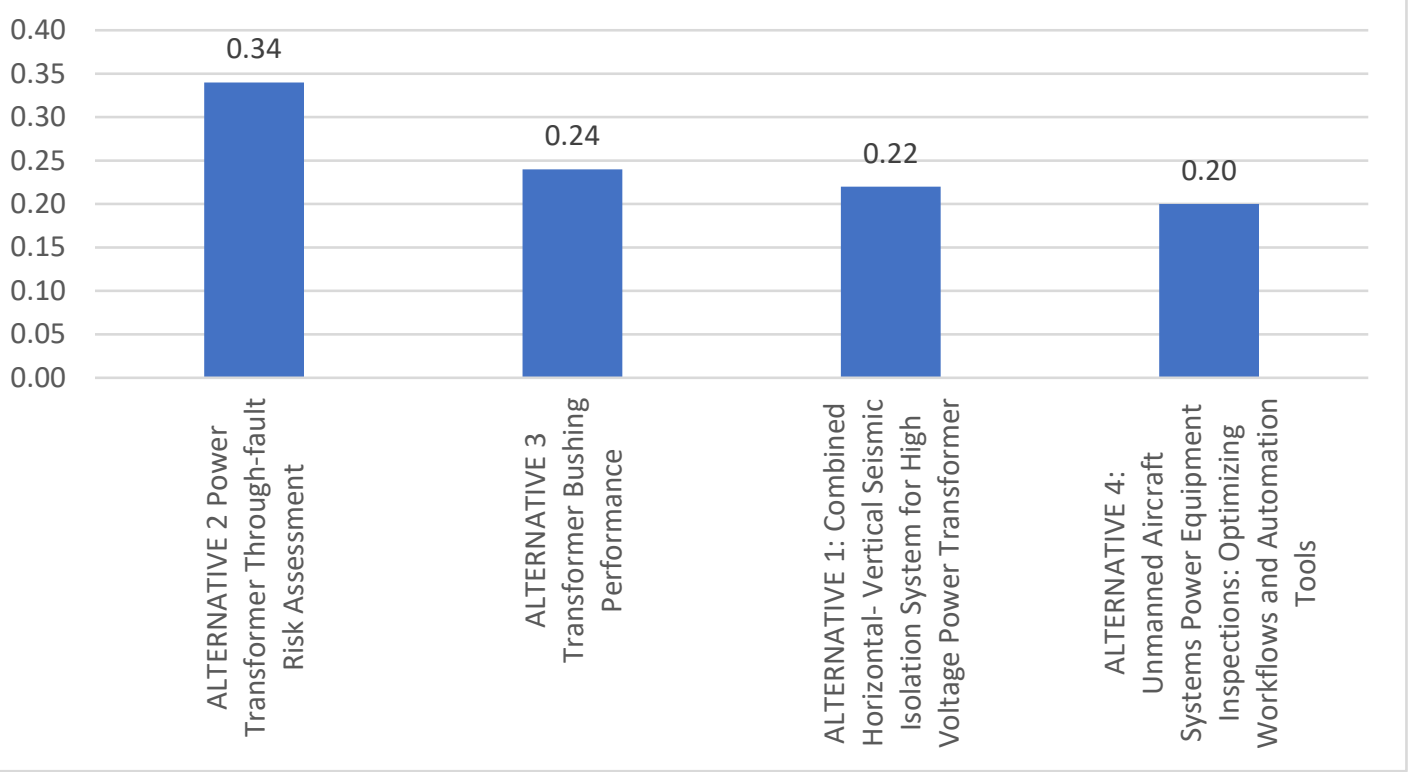

Figure 42: Relative Importance of Alternatives Respect to Availability of Resources Sub-criterion 
According to the results, Alternative 2 scored the most important (34\%) with respect to the Availability of Resources sub-criterion. Alternative 3, Alternative 1, and Alternative 4 followed in importance (24\%, 22\%, and 20\%, respectively).

The inconsistency within each expert is acceptable (all $<0.10)$. There is also no significant level of disagreement among experts (0.084).

\section{Results of Alternatives with Respect to Applicability to Other Products and Processes}

\section{Sub-criterion}

Expert panel EP2 evaluated the relative importance of alternatives with respect to the Applicability to Other Products and Processes sub-criterion using the research instrument RI4. The arithmetic means of experts' judgments for the relative importance of considered alternatives are shown in Table 48 and Figure 43 below.

Table 48: Relative Importance of Alternatives Respect to Applicability to Other Products and Processes

Sub-criterion

\begin{tabular}{|c|c|c|c|c|c|}
\hline & Alternative 1 & Alternative 2 & Alternative 3 & Alternative 4 & \\
\hline $\begin{array}{l}\text { Applicability } \\
\text { to other } \\
\text { Products and } \\
\text { Processes }\end{array}$ & $\begin{array}{c}\text { Combined } \\
\text { Horizontal- } \\
\text { Vertical Seismic } \\
\text { Isolation System } \\
\text { for High Voltage } \\
\text { Power } \\
\text { Transformer } \\
\end{array}$ & $\begin{array}{c}\text { Power } \\
\text { Transformer } \\
\text { Through-fault } \\
\text { Risk } \\
\text { Assessment }\end{array}$ & $\begin{array}{l}\text { Transformer } \\
\text { Bushing } \\
\text { Performance }\end{array}$ & $\begin{array}{c}\text { Unmanned } \\
\text { Aircraft Systems } \\
\text { Power Equipment } \\
\text { Inspections: } \\
\text { Optimizing } \\
\text { Workflows and } \\
\text { Automation Tools }\end{array}$ & Inconsistency \\
\hline Expert 16 & 0.53 & 0.31 & 0.10 & 0.06 & 0.04 \\
\hline Expert 25 & 0.43 & 0.24 & 0.16 & 0.17 & 0.01 \\
\hline Expert 28 & 0.21 & 0.33 & 0.19 & 0.27 & 0.01 \\
\hline Expert 27 & 0.34 & 0.19 & 0.32 & 0.15 & 0.01 \\
\hline Expert 5 & 0.13 & 0.20 & 0.20 & 0.48 & 0.00 \\
\hline Expert 4 & 0.25 & 0.25 & 0.25 & 0.25 & 0.00 \\
\hline Expert 15 & 0.25 & 0.33 & 0.37 & 0.05 & 0.01 \\
\hline Mean & 0.31 & 0.26 & 0.23 & 0.20 & \\
\hline Minimum & 0.13 & 0.19 & 0.10 & 0.05 & \\
\hline Maximum & 0.53 & 0.33 & 0.37 & 0.48 & \\
\hline Std. Deviation & 0.13 & 0.05 & 0.09 & 0.14 & \\
\hline Disagreement & & & & & 0.097 \\
\hline
\end{tabular}




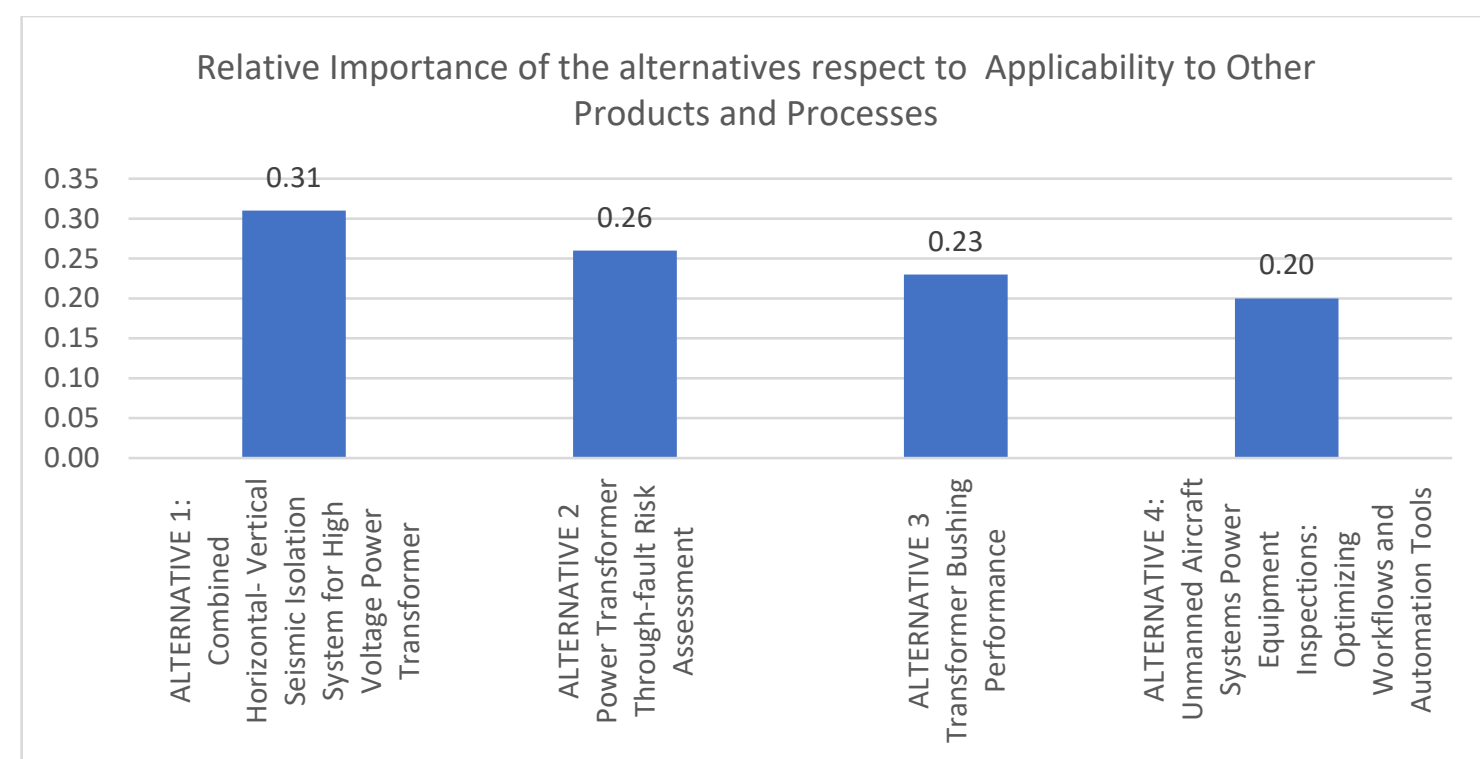

Figure 43: Relative Importance of Alternatives Respect to Applicability to Other Products and Processes Sub-criterion

According to the results, Alternative 1 scored the most important (31\%) with respect to Applicability to Other Products and Processes. Alternative 2, Alternative 3, and Alternative 4 followed in importance $(26 \%, 23 \%$, and 20\%, respectively).

The inconsistency within each expert is acceptable $($ all $<0.10)$. There is also no significant level of disagreement among experts (0.097).

\section{Results of Alternatives with Respect to Technology Readiness Sub-criterion}

Expert panel EP2 evaluated the relative importance of alternatives with respect to the Technology Readiness sub-criterion using the research instrument RI4. The arithmetic means of experts' judgments for the relative importance of considered alternatives are shown in Table 49 and Figure 44 below.

Table 49: Relative Importance of Alternatives Respect to Technology Readiness Sub-criterion 


\begin{tabular}{|c|c|c|c|c|c|}
\hline & Alternative 1 & Alternative 2 & Alternative 3 & Alternative 4 & \\
\hline $\begin{array}{l}\text { Technology } \\
\text { Readiness }\end{array}$ & $\begin{array}{c}\text { Combined } \\
\text { Horizontal- } \\
\text { Vertical } \\
\text { Seismic } \\
\text { Isolation } \\
\text { System for } \\
\text { High Voltage } \\
\text { Power } \\
\text { Transformer } \\
\end{array}$ & $\begin{array}{c}\text { Power } \\
\text { Transformer } \\
\text { Through- } \\
\text { fault Risk } \\
\text { Assessment }\end{array}$ & $\begin{array}{l}\text { Transformer } \\
\text { Bushing } \\
\text { Performance }\end{array}$ & $\begin{array}{c}\text { Unmanned } \\
\text { Aircraft } \\
\text { Systems Power } \\
\text { Equipment } \\
\text { Inspections: } \\
\text { Optimizing } \\
\text { Workflows and } \\
\text { Automation } \\
\text { Tools } \\
\end{array}$ & Inconsistency \\
\hline Expert 16 & 0.41 & 0.36 & 0.13 & 0.09 & 0.01 \\
\hline Expert 25 & 0.41 & 0.39 & 0.17 & 0.03 & 0.05 \\
\hline Expert 28 & 0.22 & 0.33 & 0.18 & 0.27 & 0.01 \\
\hline Expert 27 & 0.17 & 0.29 & 0.38 & 0.16 & 0.01 \\
\hline Expert 5 & 0.50 & 0.14 & 0.26 & 0.10 & 0.09 \\
\hline Expert 4 & 0.25 & 0.25 & 0.25 & 0.25 & 0.00 \\
\hline Expert 15 & 0.31 & 0.31 & 0.32 & 0.05 & 0.00 \\
\hline Mean & 0.32 & 0.30 & 0.24 & 0.14 & \\
\hline Minimum & 0.17 & 0.14 & 0.13 & 0.03 & \\
\hline Maximum & 0.50 & 0.39 & 0.38 & 0.27 & \\
\hline Std. Deviation & 0.11 & 0.08 & 0.08 & 0.09 & \\
\hline Disagreement & & & & & 0.088 \\
\hline
\end{tabular}

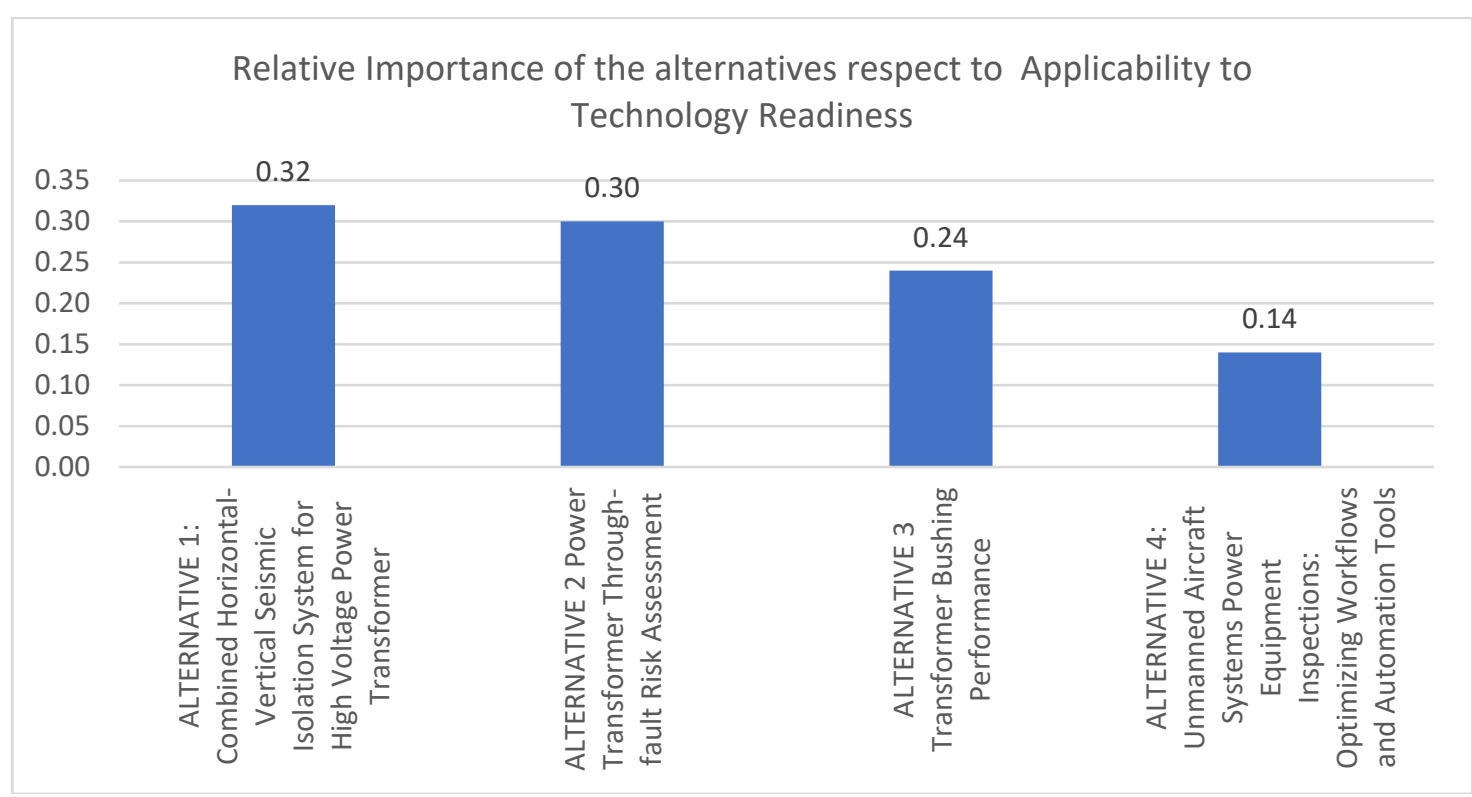

Figure 44: Relative Importance of Alternatives Respect to Technology Readiness Sub-criterion 
According to the results, Alternative 1 scored the most important (32\%) with respect to Technology Readiness. Alternative 2, Alternative 3, and Alternative 4 followed in importance $(30 \%, 24 \%$, and $14 \%$, respectively).

The inconsistency within each expert is acceptable (all $<0.10)$. There is also no significant level of disagreement among experts (0.088).

\section{Results of Alternatives with Respect to Potential Size of Market Sub-criterion}

Expert panel EP2 evaluated the relative importance of alternatives with respect to the Potential Size of Market sub-criterion using the research instrument RI4. The arithmetic means of experts' judgments for the relative importance of considered alternatives are shown in Table 50 and Figure 45 below.

Table 50: Relative Importance of Alternatives Respect to Potential Size of Market Sub-criterion

\begin{tabular}{|c|c|c|c|c|c|}
\hline \multirow[b]{2}{*}{$\begin{array}{c}\text { Potential Size } \\
\text { of Market }\end{array}$} & Alternative 1 & Alternative 2 & Alternative 3 & Alternative 4 & \multirow[b]{2}{*}{ Inconsistency } \\
\hline & $\begin{array}{c}\text { Combined } \\
\text { Horizontal- } \\
\text { Vertical } \\
\text { Seismic } \\
\text { Isolation } \\
\text { System for } \\
\text { High Voltage } \\
\text { Power } \\
\text { Transformer } \\
\end{array}$ & $\begin{array}{c}\text { Power } \\
\text { Transformer } \\
\text { Through-fault } \\
\text { Risk } \\
\text { Assessment }\end{array}$ & $\begin{array}{l}\text { Transformer } \\
\text { Bushing } \\
\text { Performance }\end{array}$ & $\begin{array}{c}\text { Unmanned } \\
\text { Aircraft Systems } \\
\text { Power } \\
\text { Equipment } \\
\text { Inspections: } \\
\text { Optimizing } \\
\text { Workflows and } \\
\text { Automation } \\
\text { Tools } \\
\end{array}$ & \\
\hline Expert 8 & 0.36 & 0.21 & 0.14 & 0.29 & 0.05 \\
\hline Expert 1 & 0.23 & 0.32 & 0.31 & 0.14 & 0.04 \\
\hline Expert 18 & 0.38 & 0.11 & 0.34 & 0.16 & 0.07 \\
\hline Expert 11 & 0.48 & 0.09 & 0.21 & 0.21 & 0.08 \\
\hline Expert 9 & 0.16 & 0.29 & 0.42 & 0.13 & 0.07 \\
\hline Expert 14 & 0.27 & 0.26 & 0.19 & 0.27 & 0.00 \\
\hline Expert 2 & 0.13 & 0.23 & 0.38 & 0.26 & 0.03 \\
\hline Mean & 0.29 & 0.22 & 0.28 & 0.21 & \\
\hline Minimum & 0.13 & 0.09 & 0.14 & 0.13 & \\
\hline Maximum & 0.48 & 0.32 & 0.42 & 0.29 & \\
\hline Std. Deviation & 0.12 & 0.08 & 0.10 & 0.06 & \\
\hline Disagreement & & & & & 0.089 \\
\hline
\end{tabular}




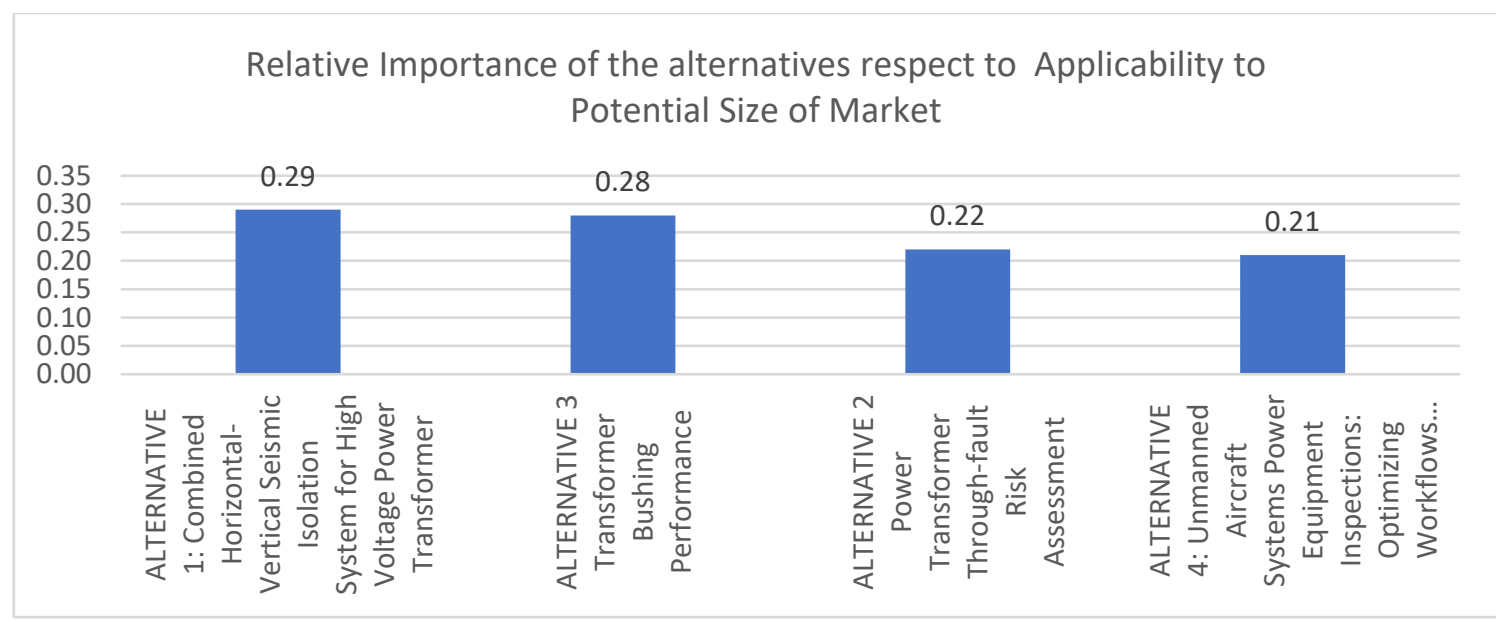

Figure 45: Relative Importance of Alternatives Respect to Applicability to Potential Size of Market

According to the results, Alternative 1 scored the most important (29\%) with respect to Potential Size of Market. Alternative 3, Alternative 2, and Alternative 4 followed in importance $(28 \%, 22 \%$, and $21 \%$, respectively).

The inconsistency within each expert is acceptable (all $<0.10)$. There is also no significant level of disagreement among experts (0.089).

\section{Results of Alternatives with Respect to Time to Market Sub-criterion}

Expert panel EP2 evaluated the relative importance of alternatives with respect to the Time to Market sub-criterion using the research instrument RI4. The arithmetic means of experts' judgments for the relative importance of considered alternatives are shown in Table 51 and Figure 46 below. 
Table 51: Relative Importance of Alternatives Respect to Time to Market Sub-criterion

\begin{tabular}{|c|c|c|c|c|c|}
\hline & Alternative 1 & Alternative 2 & Alternative 3 & Alternative 4 & \\
\hline $\begin{array}{l}\text { Time to } \\
\text { Market }\end{array}$ & $\begin{array}{c}\text { Combined } \\
\text { Horizontal- } \\
\text { Vertical } \\
\text { Seismic } \\
\text { Isolation } \\
\text { System for } \\
\text { High Voltage } \\
\text { Power } \\
\text { Transformer }\end{array}$ & $\begin{array}{c}\text { Power } \\
\text { Transformer } \\
\text { Through-fault } \\
\text { Risk } \\
\text { Assessment }\end{array}$ & $\begin{array}{c}\text { Transformer } \\
\text { Bushing } \\
\text { Performance }\end{array}$ & $\begin{array}{c}\text { Unmanned } \\
\text { Aircraft } \\
\text { Systems } \\
\text { Power } \\
\text { Equipment } \\
\text { Inspections: } \\
\text { Optimizing } \\
\text { Workflows } \\
\text { and } \\
\text { Automation } \\
\text { Tools }\end{array}$ & Inconsistency \\
\hline Expert 8 & 0.37 & 0.20 & 0.27 & 0.17 & 0.06 \\
\hline Expert 1 & 0.15 & 0.25 & 0.39 & 0.21 & 0.06 \\
\hline Expert 18 & 0.36 & 0.20 & 0.36 & 0.09 & 0.01 \\
\hline Expert 11 & 0.59 & 0.27 & 0.12 & 0.03 & 0.09 \\
\hline Expert 9 & 0.22 & 0.18 & 0.18 & 0.42 & 0.01 \\
\hline Expert 14 & 0.32 & 0.29 & 0.18 & 0.21 & 0.01 \\
\hline Expert 2 & 0.22 & 0.30 & 0.30 & 0.18 & 0.04 \\
\hline Mean & 0.32 & 0.24 & 0.26 & 0.19 & \\
\hline Minimum & 0.15 & 0.18 & 0.12 & 0.03 & \\
\hline Maximum & 0.59 & 0.30 & 0.39 & 0.42 & \\
\hline $\begin{array}{l}\text { Std. } \\
\text { Deviation }\end{array}$ & 0.13 & 0.04 & 0.09 & 0.11 & \\
\hline Disagreement & & & & & 0.091 \\
\hline
\end{tabular}

Relative Importance of the alternatives respect to Applicability to Time to Market

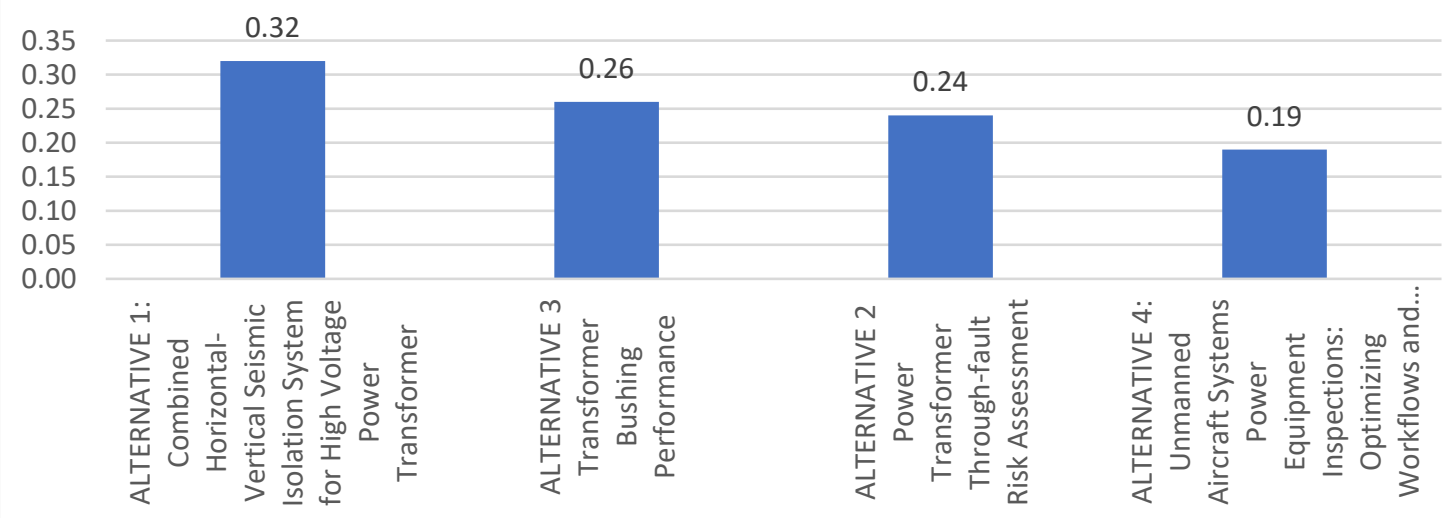

Figure 46: Relative Importance of Alternatives Respect to Time to Market Sub-criterion 
According to the results, Alternative 1 scored the most important (32\%) with respect to Time to Market. Alternative 3, Alternative 2, and Alternative 4 followed in importance $(26 \%, 24 \%$, and $19 \%$, respectively).

The inconsistency within each expert is acceptable (all $<0.10)$. There is also no significant level of disagreement among experts (0.091).

\section{Results of Alternatives with Respect to Potential Size of Market Sub-criterion}

Expert panel EP2 evaluated the relative importance of alternatives with respect to the Potential Size of Market sub-criterion using the research instrument RI4. The arithmetic means of experts' judgments for the relative importance of considered alternatives are shown in Table 52 and Figure 47 below.

Table 52: Relative Importance of Alternatives Respect to Additional (variety) applications opened Subcriterion

\begin{tabular}{|c|c|c|c|c|c|}
\hline & Alternative 1 & Alternative 2 & Alternative 3 & Alternative 4 & \\
\hline $\begin{array}{l}\text { Additional } \\
\text { (variety) } \\
\text { Applications } \\
\text { Opened }\end{array}$ & $\begin{array}{c}\text { Combined } \\
\text { Horizontal- } \\
\text { Vertical } \\
\text { Seismic } \\
\text { Isolation } \\
\text { System for } \\
\text { High Voltage } \\
\text { Power } \\
\text { Transformer }\end{array}$ & $\begin{array}{c}\text { Power } \\
\text { Transformer } \\
\text { Through- } \\
\text { fault Risk } \\
\text { Assessment }\end{array}$ & $\begin{array}{l}\text { Transformer } \\
\text { Bushing } \\
\text { Performance }\end{array}$ & $\begin{array}{c}\text { Unmanned } \\
\text { Aircraft Systems } \\
\text { Power } \\
\text { Equipment } \\
\text { Inspections: } \\
\text { Optimizing } \\
\text { Workflows and } \\
\text { Automation } \\
\text { Tools }\end{array}$ & Inconsistency \\
\hline Expert 8 & 0.30 & 0.25 & 0.26 & 0.18 & 0.09 \\
\hline Expert 1 & 0.26 & 0.38 & 0.26 & 0.10 & 0.03 \\
\hline Expert 18 & 0.41 & 0.17 & 0.35 & 0.07 & 0.04 \\
\hline Expert 11 & 0.50 & 0.28 & 0.08 & 0.14 & 0.07 \\
\hline Expert 9 & 0.24 & 0.19 & 0.19 & 0.38 & 0.02 \\
\hline Expert 14 & 0.28 & 0.22 & 0.16 & 0.34 & 0.00 \\
\hline Expert 2 & 0.11 & 0.23 & 0.19 & 0.47 & 0.01 \\
\hline Mean & 0.30 & 0.25 & 0.21 & 0.24 & \\
\hline Minimum & 0.11 & 0.17 & 0.08 & 0.07 & \\
\hline Maximum & 0.50 & 0.38 & 0.35 & 0.47 & \\
\hline Std. Deviation & 0.12 & 0.06 & 0.08 & 0.14 & \\
\hline Disagreement & & & & & 0.099 \\
\hline
\end{tabular}




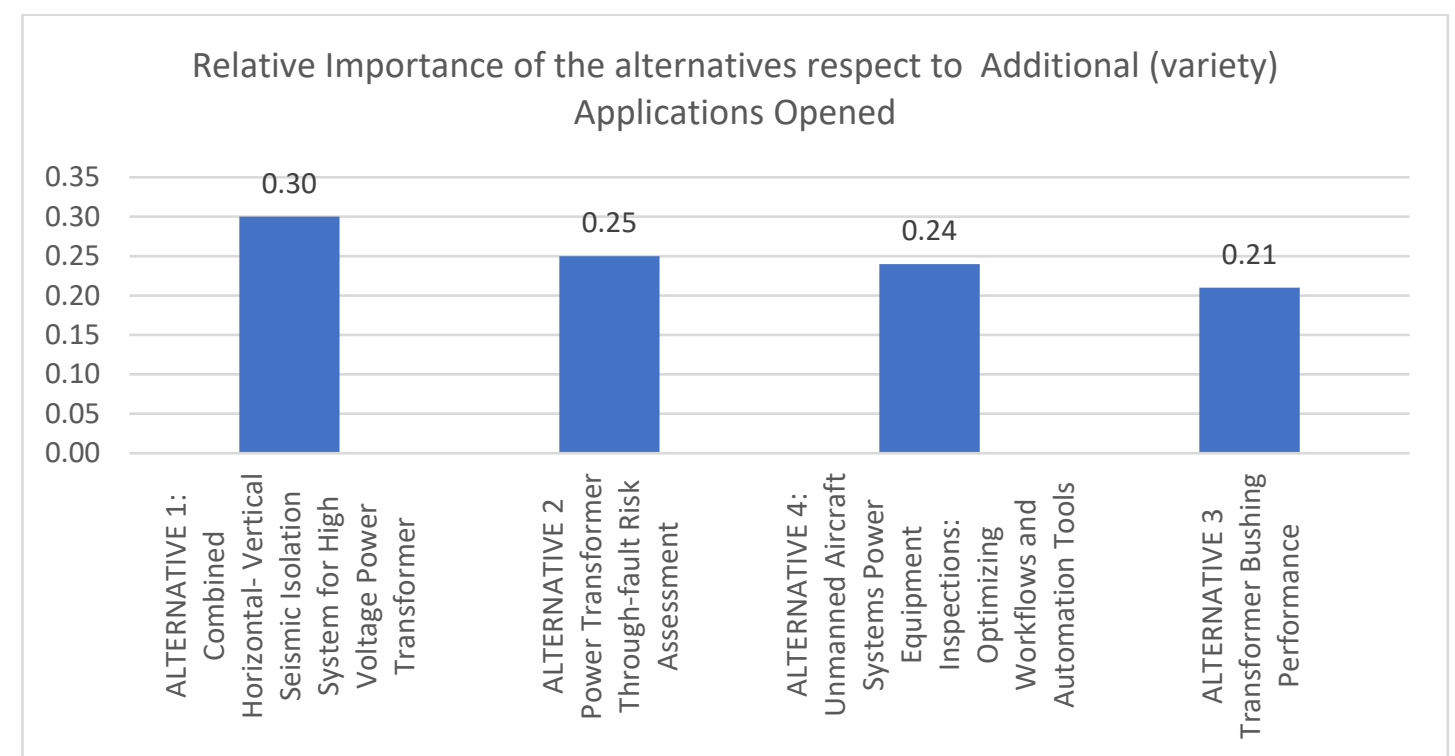

Figure 47: Relative Importance of Alternatives Respect to Additional (variety) Applications Opened Subcriterion

According to the results, Alternative 1 scored the most important (30\%) with respect to Additional (variety) Applications Opened sub-criterion. Alternative 2, Alternative 4, and Alternative 3 followed in importance $(25 \%$, and $24 \%$, and $21 \%$, respectively).

The inconsistency within each expert is acceptable (all $<0.10)$. There is also no significant level of disagreement among experts (0.099).

\section{Results of Alternatives with Respect to Market Risk Sub-criterion}

Expert panel EP2 evaluated the relative importance of alternatives with respect to the Market Risk sub-criterion using the research instrument RI4. The arithmetic means of 
experts' judgments for the relative importance of considered alternatives are shown in Table 53 and Figure 48 below.

According to the results, Alternative 4 scored the most important (30\%) with respect to Market Risk sub-criterion. Alternative 2, Alternative 1, and Alternative 3 followed in importance $(27 \%$, and $23 \%$, and $22 \%$, respectively).

The inconsistency within each expert is acceptable $($ all $<0.10)$. There is also no significant level of disagreement among experts (0.088).

Table 53: Relative Importance of Alternatives Respect to Market Risk Sub-criterion

\begin{tabular}{|c|c|c|c|c|c|}
\hline & Alternative 1 & Alternative 2 & Alternative 3 & Alternative 4 & \\
\hline Market Risk & $\begin{array}{l}\text { Combined } \\
\text { Horizontal- } \\
\text { Vertical } \\
\text { Seismic } \\
\text { Isolation } \\
\text { System for } \\
\text { High Voltage } \\
\text { Power } \\
\text { Transformer }\end{array}$ & $\begin{array}{c}\text { Power } \\
\text { Transformer } \\
\text { Through- } \\
\text { fault Risk } \\
\text { Assessment }\end{array}$ & $\begin{array}{l}\text { Transformer } \\
\text { Bushing } \\
\text { Performance }\end{array}$ & $\begin{array}{c}\text { Unmanned } \\
\text { Aircraft Systems } \\
\text { Power Equipment } \\
\text { Inspections: } \\
\text { Optimizing } \\
\text { Workflows and } \\
\text { Automation Tools }\end{array}$ & Inconsistency \\
\hline Expert 8 & 0.26 & 0.42 & 0.17 & 0.15 & 0.05 \\
\hline Expert 1 & 0.18 & 0.27 & 0.27 & 0.27 & 0.02 \\
\hline Expert 18 & 0.29 & 0.26 & 0.34 & 0.11 & 0.01 \\
\hline Expert 11 & 0.19 & 0.19 & 0.19 & 0.44 & 0.00 \\
\hline Expert 9 & 0.17 & 0.18 & 0.12 & 0.53 & 0.03 \\
\hline Expert 14 & 0.34 & 0.25 & 0.14 & 0.26 & 0.02 \\
\hline Expert 2 & 0.17 & 0.31 & 0.30 & 0.22 & 0.00 \\
\hline Mean & 0.23 & 0.27 & 0.22 & 0.28 & \\
\hline Minimum & 0.17 & 0.18 & 0.12 & 0.11 & \\
\hline Maximum & 0.34 & 0.42 & 0.34 & 0.53 & \\
\hline Std. Deviation & 0.06 & 0.07 & 0.08 & 0.14 & \\
\hline Disagreement & & & & & 0.088 \\
\hline
\end{tabular}




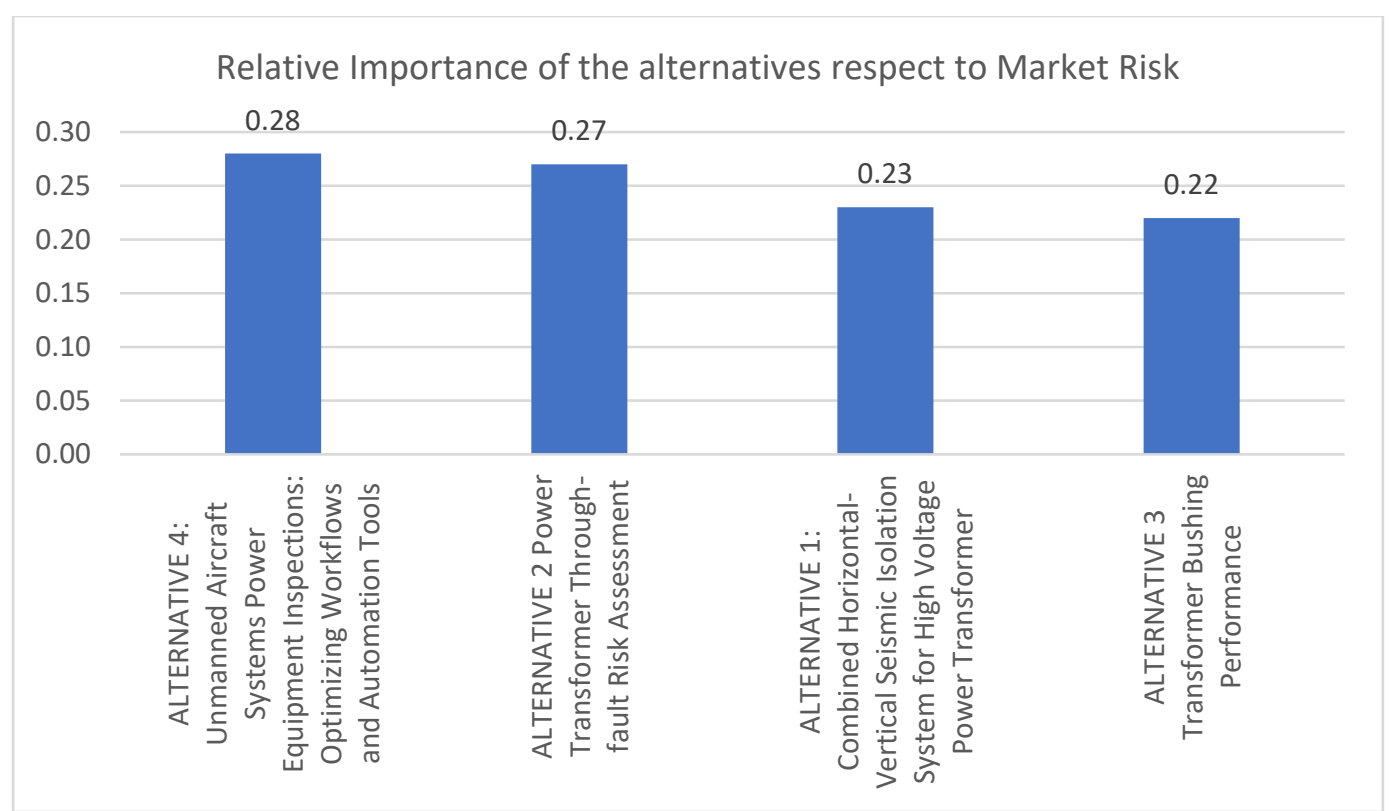

Figure 48: Relative Importance of Alternatives Respect to Market Risk Sub-criterion

\section{Results of Alternatives with Respect to System Planning Sub-criterion}

Expert panel EP2 evaluated the relative importance of alternatives with respect to the System Planning sub-criterion using the research instrument RI4. The arithmetic means of experts' judgments for the relative importance of considered alternatives are shown in Table 54 and Figure 49 below.

According to the results, Alternative 1 scored the most important (30\%) with respect to System Planning sub-criterion. Alternative 2, Alternative 4, and Alternative 3 followed in importance (26\%, and $22 \%$, and $21 \%$, respectively).

The inconsistency within each expert is acceptable (all $<0.10)$. There is also no significant level of disagreement among experts (0.092). 
Table 54: Relative Importance of Alternatives Respect to System planning Sub-criterion

\begin{tabular}{|l|c|c|c|c|c|}
\hline System & Alternative 1 & Alternative 2 & Alternative 3 & Alternative 4 & \\
\cline { 2 - 5 } Planning & $\begin{array}{c}\text { Combined } \\
\text { Horizontal- } \\
\text { Vertical } \\
\text { Seismic } \\
\text { Isolation } \\
\text { System for } \\
\text { High Voltage } \\
\text { Power } \\
\text { Transformer }\end{array}$ & $\begin{array}{c}\text { Power } \\
\text { Transformer } \\
\text { Through-fault } \\
\text { Risk } \\
\text { Assessment }\end{array}$ & $\begin{array}{c}\text { Transformer } \\
\text { Bushing } \\
\text { Performance }\end{array}$ & $\begin{array}{c}\text { Unmanned } \\
\text { Aircraft } \\
\text { Systems } \\
\text { Power } \\
\text { Equipment } \\
\text { Inspections: } \\
\text { Optimizing } \\
\text { Workflows } \\
\text { and } \\
\text { Automation } \\
\text { Tools }\end{array}$ & Inconsistency \\
\hline Expert 8 & 0.33 & 0.25 & 0.31 & 0.11 & \\
\hline Expert 1 & 0.22 & 0.33 & 0.27 & 0.18 & 0.07 \\
\hline Expert 18 & 0.25 & 0.25 & 0.25 & 0.25 & 0.01 \\
\hline Expert 11 & 0.63 & 0.21 & 0.09 & 0.07 & 0.01 \\
\hline Expert 9 & 0.21 & 0.19 & 0.14 & 0.46 & 0.01 \\
\hline Expert 14 & 0.21 & 0.32 & 0.14 & 0.32 & 0.01 \\
\hline Expert 2 & 0.25 & 0.30 & 0.30 & 0.16 & 0.02 \\
\hline Mean & 0.30 & 0.26 & 0.21 & 0.22 & \\
\hline Minimum & 0.21 & 0.19 & 0.09 & 0.07 & \\
\hline Maximum & 0.63 & 0.33 & 0.31 & 0.46 & \\
\hline Std. & 0.14 & 0.05 & 0.08 & 0.12 & \\
\hline Deviation & & & & & 0.092 \\
\hline Disagreement & & & & & \\
\hline
\end{tabular}

\section{Relative Importance of the alternatives respect to System Planning}

\begin{tabular}{|c|c|c|c|c|}
\hline $\begin{array}{l}0.35 \\
0.30\end{array}$ & 0.30 & \multirow{2}{*}{0.26} & \multirow[b]{2}{*}{0.22} & \multirow[b]{2}{*}{0.21} \\
\hline 0.25 & & & & \\
\hline 0.20 & & & & \\
\hline 0.15 & & & & \\
\hline 0.10 & & & & \\
\hline 0.05 & & & & \\
\hline 0.00 & 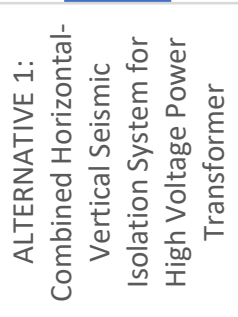 & 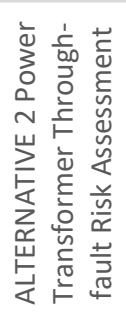 & 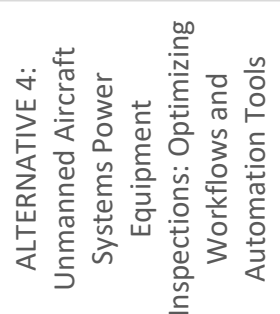 & 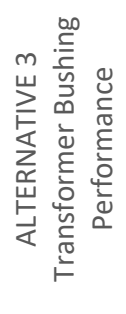 \\
\hline
\end{tabular}

Figure 49: Relative Importance of Alternatives Respect to System Planning Sub-criterion 


\section{Results of Alternatives with Respect to Research Staff Availability Sub-criterion}

Expert panel EP2 evaluated the relative importance of alternatives with respect to the Research Staff Availability sub-criterion using the research instrument RI4. The arithmetic means of experts' judgments for the relative importance of considered alternatives are shown in Table 55 and Figure 50 below.

Table 55: Relative Importance of Alternatives Respect to Research Staff Availability Sub-criterion

\begin{tabular}{|c|c|c|c|c|c|}
\hline & Alternative 1 & Alternative 2 & Alternative 3 & Alternative 4 & \\
\hline $\begin{array}{c}\text { Research } \\
\text { Staff } \\
\text { Availability }\end{array}$ & $\begin{array}{c}\text { Combined } \\
\text { Horizontal- } \\
\text { Vertical } \\
\text { Seismic } \\
\text { Isolation } \\
\text { System for } \\
\text { High Voltage } \\
\text { Power } \\
\text { Transformer }\end{array}$ & $\begin{array}{c}\text { Power } \\
\text { Transformer } \\
\text { Through- } \\
\text { fault Risk } \\
\text { Assessment }\end{array}$ & $\begin{array}{l}\text { Transformer } \\
\text { Bushing } \\
\text { Performance }\end{array}$ & $\begin{array}{c}\text { Unmanned } \\
\text { Aircraft } \\
\text { Systems Power } \\
\text { Equipment } \\
\text { Inspections: } \\
\text { Optimizing } \\
\text { Workflows } \\
\text { and } \\
\text { Automation } \\
\text { Tools } \\
\end{array}$ & Inconsistency \\
\hline Expert 1 & 0.28 & 0.30 & 0.25 & 0.18 & 0.02 \\
\hline Expert 16 & 0.28 & 0.50 & 0.13 & 0.09 & 0.07 \\
\hline Expert 21 & 0.36 & 0.17 & 0.17 & 0.31 & 0.02 \\
\hline Expert 25 & 0.37 & 0.41 & 0.18 & 0.03 & 0.06 \\
\hline Expert 28 & 0.27 & 0.27 & 0.18 & 0.27 & 0.02 \\
\hline Expert 27 & 0.36 & 0.27 & 0.23 & 0.14 & 0.00 \\
\hline Expert 23 & 0.25 & 0.25 & 0.25 & 0.25 & 0.00 \\
\hline Mean & 0.31 & 0.31 & 0.20 & 0.18 & \\
\hline Minimum & 0.25 & 0.17 & 0.13 & 0.03 & \\
\hline Maximum & 0.37 & 0.50 & 0.25 & 0.31 & \\
\hline Std. Deviation & 0.05 & 0.10 & 0.04 & 0.09 & \\
\hline Disagreement & & & & & 0.07 \\
\hline
\end{tabular}




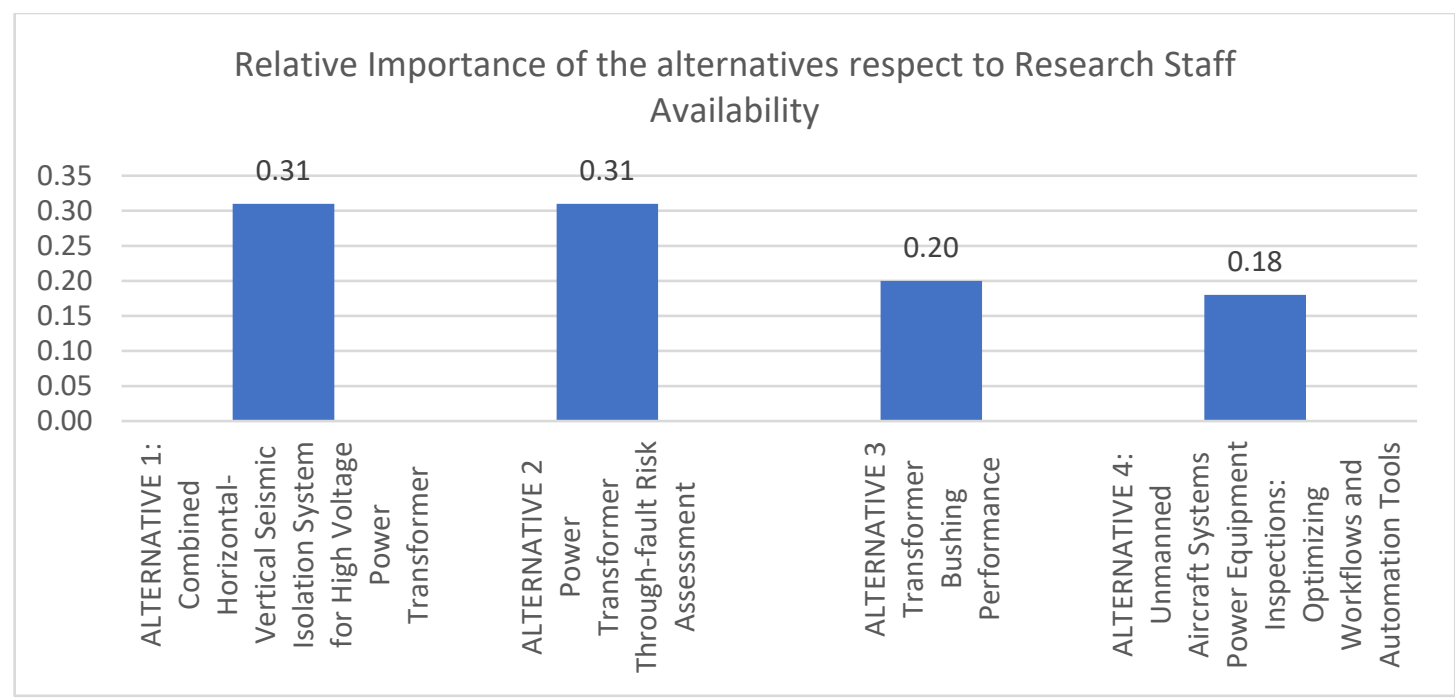

Figure 50: Relative Importance of Alternatives Respect to Research Staff Availability Sub-criterion

According to the results, Alternative 1 and Alternative 2 scored the most important (31\% each) with respect to Research Staff Availability. Alternative 3 and Alternative 4 followed in importance $(20 \%, 18 \%$, respectively).

The inconsistency within each expert is acceptable $($ all $<0.10)$. There is also no significant level of disagreement among experts (0.07).

\section{Results of Alternatives with Respect to Knowledge/Skill Availability Sub-criterion}

Expert panel EP2 evaluated the relative importance of alternatives with respect to the Knowledge/Skill Availability sub-criterion using the research instrument RI4. The arithmetic means of experts' judgments for the relative importance of considered alternatives are shown in Table 56 and Figure 51 below. 
Table 56: Relative Importance of Alternatives Respect to Knowledge/skill Availability Sub-criterion

\begin{tabular}{|l|c|c|c|c|c|}
\hline & Alternative 1 & Alternative 2 & Alternative 3 & Alternative 4 & \\
\cline { 2 - 5 } Knowledge/Skill \\
Availability & $\begin{array}{c}\text { Combined } \\
\text { Horizontal- } \\
\text { Vertical } \\
\text { Seismic } \\
\text { Isolation } \\
\text { System for } \\
\text { High Voltage } \\
\text { Power } \\
\text { Transformer }\end{array}$ & $\begin{array}{c}\text { Power } \\
\text { Transformer } \\
\text { Through- } \\
\text { fault Risk } \\
\text { Assessment }\end{array}$ & $\begin{array}{c}\text { Transformer } \\
\text { Bushing } \\
\text { Performance }\end{array}$ & $\begin{array}{c}\text { Unmanned } \\
\text { Aircraft } \\
\text { Systems } \\
\text { Power } \\
\text { Equipment } \\
\text { Inspections: } \\
\text { Optimizing } \\
\text { Workflows } \\
\text { and } \\
\text { Automation } \\
\text { Tools }\end{array}$ & Inconsistency \\
\hline Expert 1 & 0.18 & 0.25 & 0.27 & 0.30 & \\
\hline Expert 16 & 0.35 & 0.51 & 0.07 & 0.07 & 0.02 \\
\hline Expert 21 & 0.36 & 0.17 & 0.14 & 0.34 & 0.02 \\
\hline Expert 25 & 0.50 & 0.21 & 0.26 & 0.03 & 0.00 \\
\hline Expert 28 & 0.22 & 0.33 & 0.18 & 0.27 & 0.01 \\
\hline Expert 27 & 0.37 & 0.30 & 0.15 & 0.18 & 0.05 \\
\hline Expert 12 & 0.16 & 0.22 & 0.14 & 0.48 & 0.01 \\
\hline Expert 23 & 0.25 & 0.25 & 0.25 & 0.25 & 0.00 \\
\hline Mean & 0.30 & 0.28 & 0.18 & 0.24 & \\
\hline Minimum & 0.16 & 0.17 & 0.07 & 0.03 & \\
\hline Maximum & 0.50 & 0.51 & 0.27 & 0.48 & \\
\hline Std. Deviation & 0.11 & 0.10 & 0.07 & 0.14 & \\
\hline Disagreement & & & & & 0.095 \\
\hline
\end{tabular}

Relative Importance of the alternatives respect to Knowledge/Skill Availability

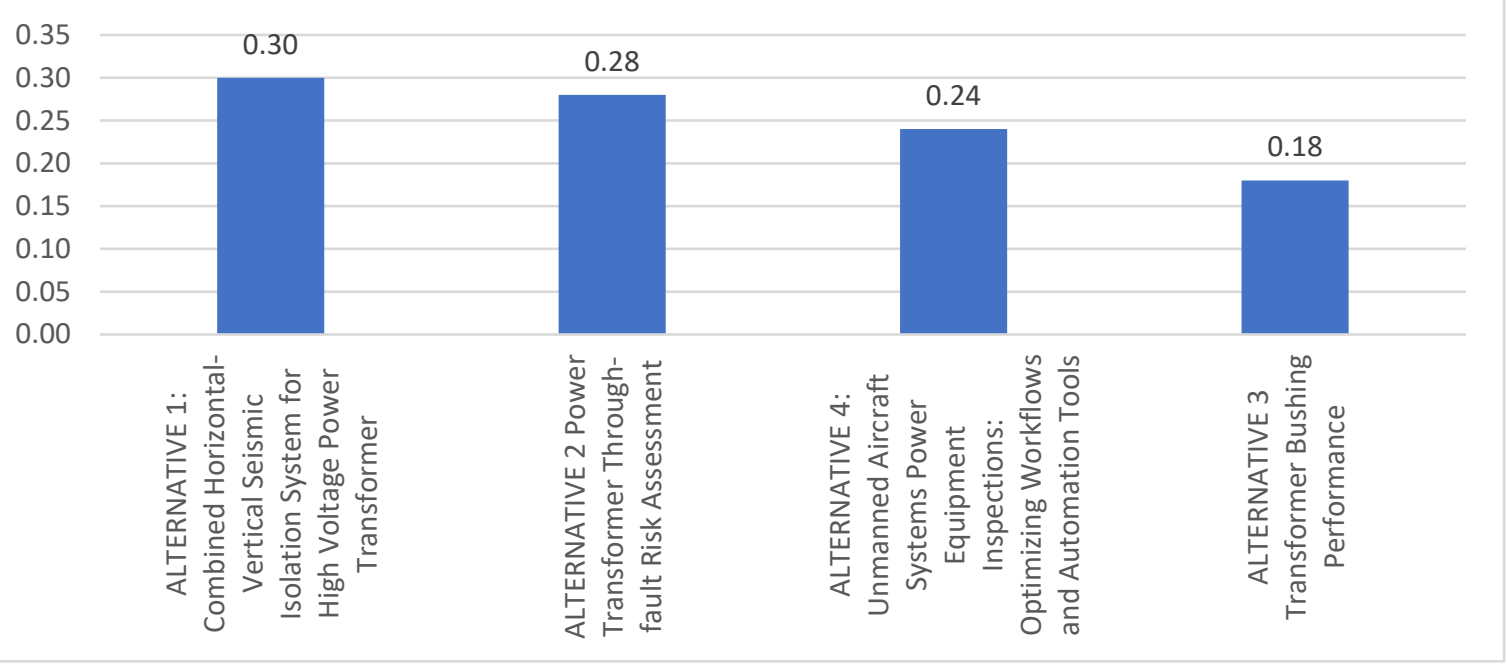

Figure 51: Relative Importance of Alternatives Respect to Knowledge/Skill Availability Sub-criterion 
According to the results, Alternative 1 scored the most important (30\%) with respect to Knowledge/Skill Availability sub-criterion. Alternative 2, Alternative 4, and Alternative 3 followed in importance $(28 \%, 24 \%$, and 18\%, respectively).

The inconsistency within each expert is acceptable (all $<0.10)$. There is also no significant level of disagreement among experts (0.095).

\section{Results of Alternatives with Respect to Competence and Experience on Similar Projects Sub-criterion}

Expert panel EP2 evaluated the relative importance of alternatives with respect to the Competence and experience on similar projects sub-criterion using the research instrument RI4. The arithmetic means of experts' judgments for the relative importance of considered alternatives are shown in Table 57 and Figure 52 below.

Table 57: Relative Importance of Alternatives Respect to Competence and Experience on Similar Projects Sub-criterion

\begin{tabular}{|c|c|c|c|c|c|}
\hline \multirow[b]{2}{*}{$\begin{array}{l}\text { Competence } \\
\text { and } \\
\text { Experience } \\
\text { on Similar } \\
\text { Projects }\end{array}$} & Alternative 1 & Alternative & Alternative 3 & Alternative 4 & \multirow[b]{2}{*}{ Inconsistency } \\
\hline & $\begin{array}{c}\text { Combined } \\
\text { Horizontal- } \\
\text { Vertical Seismic } \\
\text { Isolation System } \\
\text { for High Voltage } \\
\text { Power } \\
\text { Transformer }\end{array}$ & $\begin{array}{c}\text { Power } \\
\text { Transformer } \\
\text { Through- } \\
\text { fault Risk } \\
\text { Assessment }\end{array}$ & $\begin{array}{l}\text { Transformer } \\
\text { Bushing } \\
\text { Performance }\end{array}$ & $\begin{array}{c}\text { Unmanned } \\
\text { Aircraft Systems } \\
\text { Power Equipment } \\
\text { Inspections: } \\
\text { Optimizing } \\
\text { Workflows and } \\
\text { Automation Tools }\end{array}$ & \\
\hline Expert 1 & 0.26 & 0.32 & 0.23 & 0.19 & 0.03 \\
\hline Expert 16 & 0.29 & 0.54 & 0.10 & 0.07 & 0.01 \\
\hline Expert 21 & 0.33 & 0.12 & 0.14 & 0.41 & 0.04 \\
\hline Expert 28 & 0.27 & 0.32 & 0.19 & 0.22 & 0.01 \\
\hline Expert 27 & 0.27 & 0.12 & 0.14 & 0.47 & 0.01 \\
\hline Expert 12 & 0.16 & 0.19 & 0.14 & 0.52 & 0.01 \\
\hline Expert 23 & 0.25 & 0.25 & 0.25 & 0.25 & 0.00 \\
\hline Mean & 0.26 & 0.27 & 0.17 & 0.30 & \\
\hline Minimum & 0.16 & 0.12 & 0.10 & 0.07 & \\
\hline Maximum & 0.33 & 0.54 & 0.25 & 0.52 & \\
\hline Std. Deviation & 0.05 & 0.14 & 0.05 & 0.15 & \\
\hline Disagreement & & & & & 0.099 \\
\hline
\end{tabular}




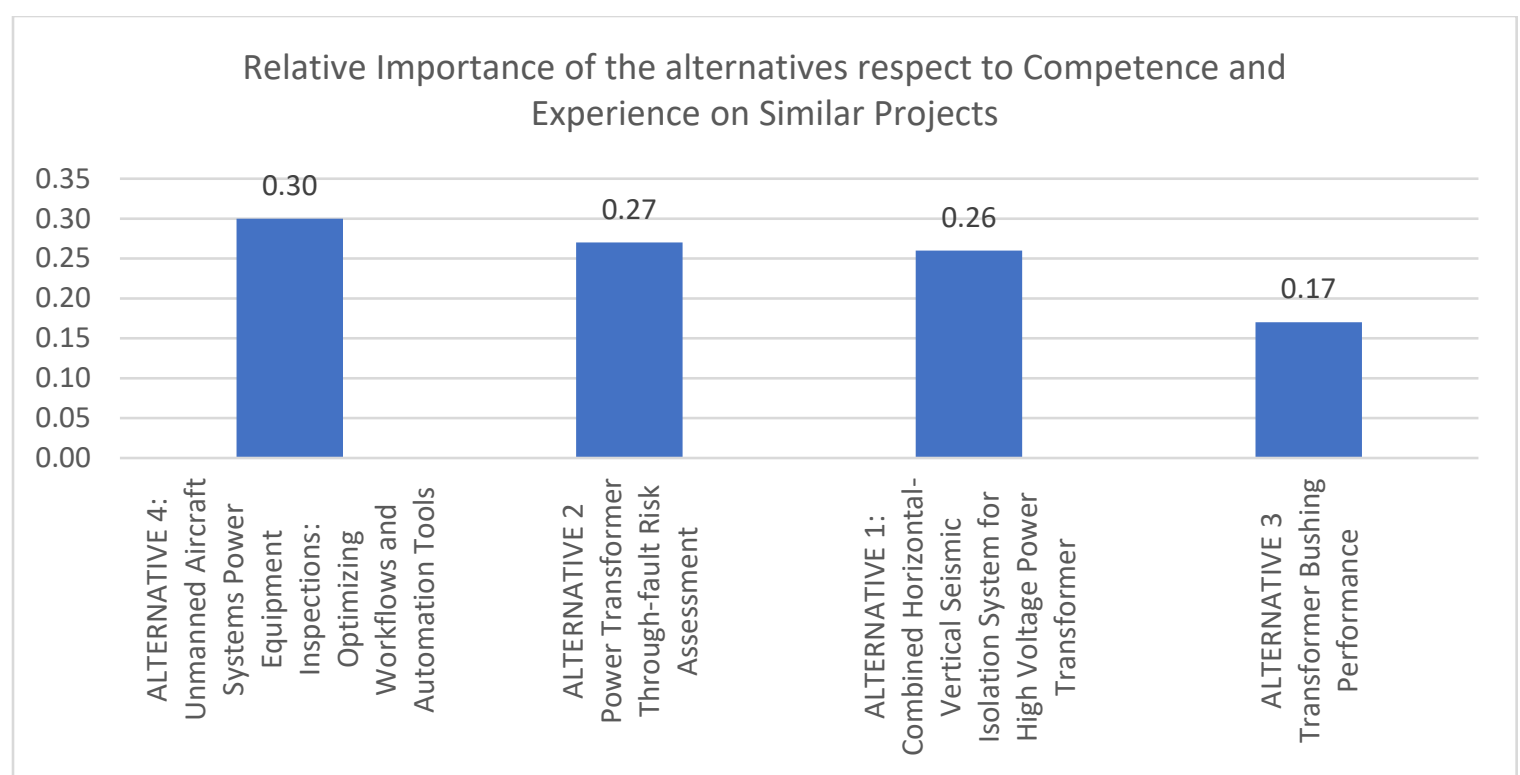

Figure 52: Relative Importance of Alternatives Respect to Competence and Experience on Similar Projects Sub-criterion

According to the results, Alternative 4 scored the most important (30\%) with respect to Competence and Experience on similar projects. Alternative 2, Alternative 1, and Alternative 3 followed in importance $(27 \%, 26 \%$, and $17 \%$, respectively).

The inconsistency within each expert is acceptable (all $<0.10)$. There is also no significant level of disagreement among experts (0.099).

\section{Results of Alternatives with Respect to Strategic Fit Sub-criterion}

Expert panel EP2 evaluated the relative importance of alternatives with respect to the Strategic Fit sub-criterion using the research instrument RI4. The arithmetic means of experts' judgments for the relative importance of considered alternatives are shown in Table 56 and Figure 53 below. 
Table 58: Relative Importance of Alternatives Respect to Strategic Fit Sub-criterion

\begin{tabular}{|l|c|c|c|c|c|}
\hline Strategic Fit & Alternative 1 & Alternative 2 & Alternative 3 & Alternative 4 & \\
\cline { 2 - 5 } & $\begin{array}{c}\text { Combined } \\
\text { Horizontal- } \\
\text { Vertical } \\
\text { Seismic } \\
\text { Isolation } \\
\text { System for } \\
\text { High Voltage } \\
\text { Power } \\
\text { Transformer }\end{array}$ & $\begin{array}{c}\text { Power } \\
\text { Through- } \\
\text { fault Risk } \\
\text { Assessment }\end{array}$ & $\begin{array}{c}\text { Transformer } \\
\text { Bushing } \\
\text { Performance }\end{array}$ & $\begin{array}{c}\text { Unmanned } \\
\text { Aircraft } \\
\text { Systems Power } \\
\text { Equipment } \\
\text { Inspections: } \\
\text { Optimizing } \\
\text { Workflows } \\
\text { and }\end{array}$ & Inconsistency \\
\hline Expert 1 & 0.21 & 0.37 & 0.27 & 0.16 & \\
\hline Expert 16 & 0.32 & 0.47 & 0.14 & 0.07 & 0.01 \\
\hline Expert 21 & 0.43 & 0.13 & 0.11 & 0.33 & 0.01 \\
\hline Expert 25 & 0.30 & 0.22 & 0.42 & 0.05 & 0.08 \\
\hline Expert 28 & 0.28 & 0.32 & 0.19 & 0.22 & 0.01 \\
\hline Expert 27 & 0.32 & 0.16 & 0.10 & 0.42 & 0.00 \\
\hline Expert 12 & 0.17 & 0.26 & 0.15 & 0.42 & 0.01 \\
\hline Expert 23 & 0.25 & 0.25 & 0.25 & 0.25 & 0.00 \\
\hline Mean & 0.29 & 0.27 & 0.20 & 0.24 & \\
\hline Minimum & 0.17 & 0.13 & 0.10 & 0.05 & \\
\hline Maximum & 0.43 & 0.47 & 0.42 & 0.42 & \\
\hline Std. & 0.07 & 0.10 & 0.10 & 0.13 & \\
\hline Deviation & & & & & \\
\hline Disagreement & & & & & \\
\hline & & & & & \\
\hline
\end{tabular}

Relative Importance of the alternatives respect to Strategic Fit

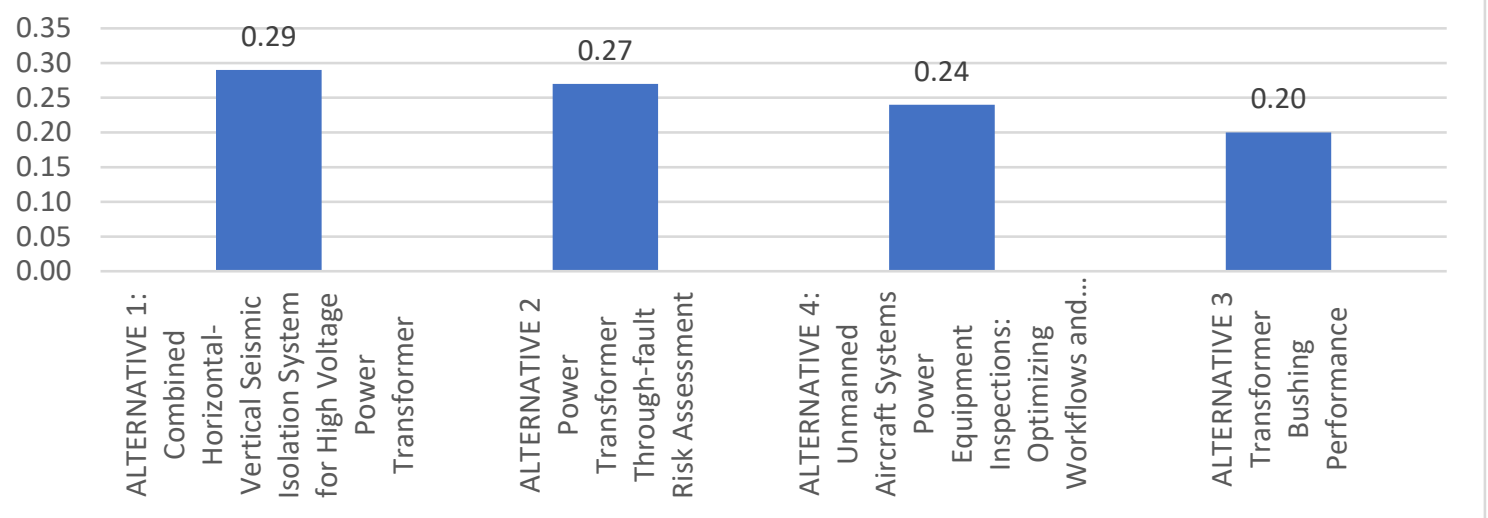

Figure 53: Relative Importance of Alternatives Respect to Strategic Fit Sub-criterion 
According to the results, Alternative 1 scored the most important (29\%) with respect to Strategic Fit. Alternative 2, Alternative 4, and Alternative 3 followed in importance $(27 \%, 24 \%$, and $20 \%$, respectively).

The inconsistency within each expert is acceptable (all $<0.10)$. There is also no significant level of disagreement among experts (0.096).

\section{Results of Alternatives with Respect to Available facilities Sub-criterion}

Expert panel EP2 evaluated the relative importance of alternatives with respect to the Available Facilities sub-criterion using the research instrument RI4. The arithmetic means of experts' judgments for the relative importance of considered alternatives are shown in Table 59 and Figure 54 below.

Table 59: Relative Importance of Alternatives Respect to Available Facilities Sub-criterion

\begin{tabular}{|c|c|c|c|c|c|}
\hline & Alternative 1 & Alternative 2 & Alternative 3 & Alternative 4 & \\
\hline $\begin{array}{l}\text { Available } \\
\text { Facilities }\end{array}$ & $\begin{array}{c}\text { Combined } \\
\text { Horizontal- } \\
\text { Vertical Seismic } \\
\text { Isolation System } \\
\text { for High Voltage } \\
\text { Power } \\
\text { Transformer }\end{array}$ & $\begin{array}{c}\text { Power } \\
\text { Transformer } \\
\text { Through- } \\
\text { fault Risk } \\
\text { Assessment }\end{array}$ & $\begin{array}{l}\text { Transformer } \\
\text { Bushing } \\
\text { Performance }\end{array}$ & $\begin{array}{c}\text { Unmanned } \\
\text { Aircraft Systems } \\
\text { Power Equipment } \\
\text { Inspections: } \\
\text { Optimizing } \\
\text { Workflows and } \\
\text { Automation Tools }\end{array}$ & Inconsistency \\
\hline Expert 1 & 0.24 & 0.28 & 0.34 & 0.15 & 0.02 \\
\hline Expert 16 & 0.36 & 0.46 & 0.12 & 0.06 & 0.05 \\
\hline Expert 21 & 0.14 & 0.21 & 0.16 & 0.50 & 0.03 \\
\hline Expert 25 & 0.16 & 0.54 & 0.23 & 0.06 & 0.04 \\
\hline Expert 28 & 0.27 & 0.30 & 0.20 & 0.23 & 0.01 \\
\hline Expert 27 & 0.34 & 0.30 & 0.18 & 0.18 & 0.01 \\
\hline Expert 12 & 0.17 & 0.23 & 0.17 & 0.43 & 0.01 \\
\hline Expert 23 & 0.25 & 0.25 & 0.25 & 0.25 & 0.00 \\
\hline Mean & 0.24 & 0.32 & 0.21 & 0.23 & \\
\hline Minimum & 0.14 & 0.21 & 0.12 & 0.06 & \\
\hline Maximum & 0.36 & 0.54 & 0.34 & 0.50 & \\
\hline Std. Deviation & 0.08 & 0.11 & 0.06 & 0.15 & \\
\hline Disagreement & & & & & 0.094 \\
\hline
\end{tabular}




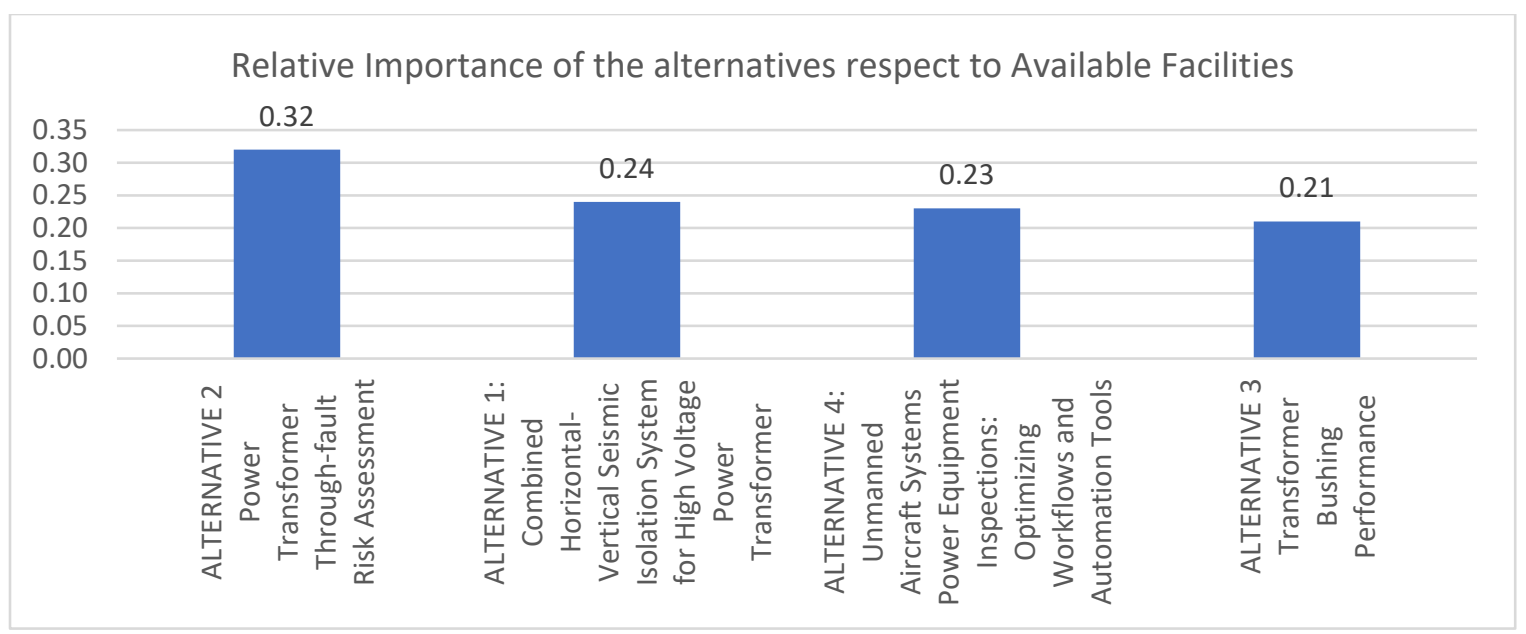

Figure 54: Relative Importance of Alternatives Respect to Available Facilities Sub-criterion

According to the results, Alternative 2 scored the most important (32\%) with respect to Available Facilities. Alternative 1, Alternative 4, and Alternative 3 followed in importance $(24 \%, 23 \%$, and $21 \%$, respectively).

The inconsistency within each expert is acceptable $($ all $<0.10)$. There is also no significant level of disagreement among experts (0.094).

\section{Results of Alternatives with Respect to Net Present Value (NPV) Sub-criterion}

Expert panel EP2 evaluated the relative importance of alternatives with respect to the Net present value (NPV) sub-criterion using the research instrument RI4. The arithmetic means of experts' judgments for the relative importance of considered alternatives are shown in Table 60 and Figure 55 below. 
Table 60: Relative Importance of Alternatives Respect to Net Present Value (NPV) Sub-criterion

\begin{tabular}{|l|c|c|c|c|c|}
\hline Net Present & Alternative 1 & Alternative 2 & Alternative 3 & Alternative 4 & \\
\cline { 2 - 5 } Value (NPV) & $\begin{array}{c}\text { Combined } \\
\text { Horizontal- } \\
\text { Vertical } \\
\text { Seismic } \\
\text { Isolation } \\
\text { System for } \\
\text { High Voltage } \\
\text { Power }\end{array}$ & $\begin{array}{c}\text { Power } \\
\text { Transformer } \\
\text { Through-fault } \\
\text { Risk } \\
\text { Assessment }\end{array}$ & $\begin{array}{c}\text { Transformer } \\
\text { Bushing } \\
\text { Performance }\end{array}$ & $\begin{array}{c}\text { Unmanned } \\
\text { Aircraft } \\
\text { Systems Power } \\
\text { Equipment } \\
\text { Inspections: } \\
\text { Optimizing } \\
\text { Workflows } \\
\text { and }\end{array}$ & Inconsistency \\
\hline Expert 26 & 0.14 & 0.36 & 0.29 & 0.21 & \\
\hline Expert 8 & 0.42 & 0.30 & 0.20 & 0.09 & 0.00 \\
\hline Expert 18 & 0.33 & 0.27 & 0.30 & 0.10 & 0.03 \\
\hline Expert 7 & 0.20 & 0.26 & 0.15 & 0.39 & 0.09 \\
\hline Expert 21 & 0.44 & 0.13 & 0.14 & 0.30 & 0.02 \\
\hline Expert 9 & 0.23 & 0.20 & 0.17 & 0.40 & 0.00 \\
\hline Expert 2 & 0.25 & 0.25 & 0.25 & 0.25 & 0.00 \\
\hline Expert 15 & 0.31 & 0.31 & 0.31 & 0.06 & 0.00 \\
\hline Mean & 0.29 & 0.26 & 0.23 & 0.23 & \\
\hline Minimum & 0.14 & 0.13 & 0.14 & 0.06 & \\
\hline Maximum & 0.44 & 0.36 & 0.31 & 0.40 & \\
\hline Std. Deviation & 0.10 & 0.07 & 0.07 & 0.13 & \\
\hline Disagreement & & & & & \\
\hline & & & & & \\
\hline
\end{tabular}

\section{Relative Importance of the alternatives respect to Net Present Value (NPV)}

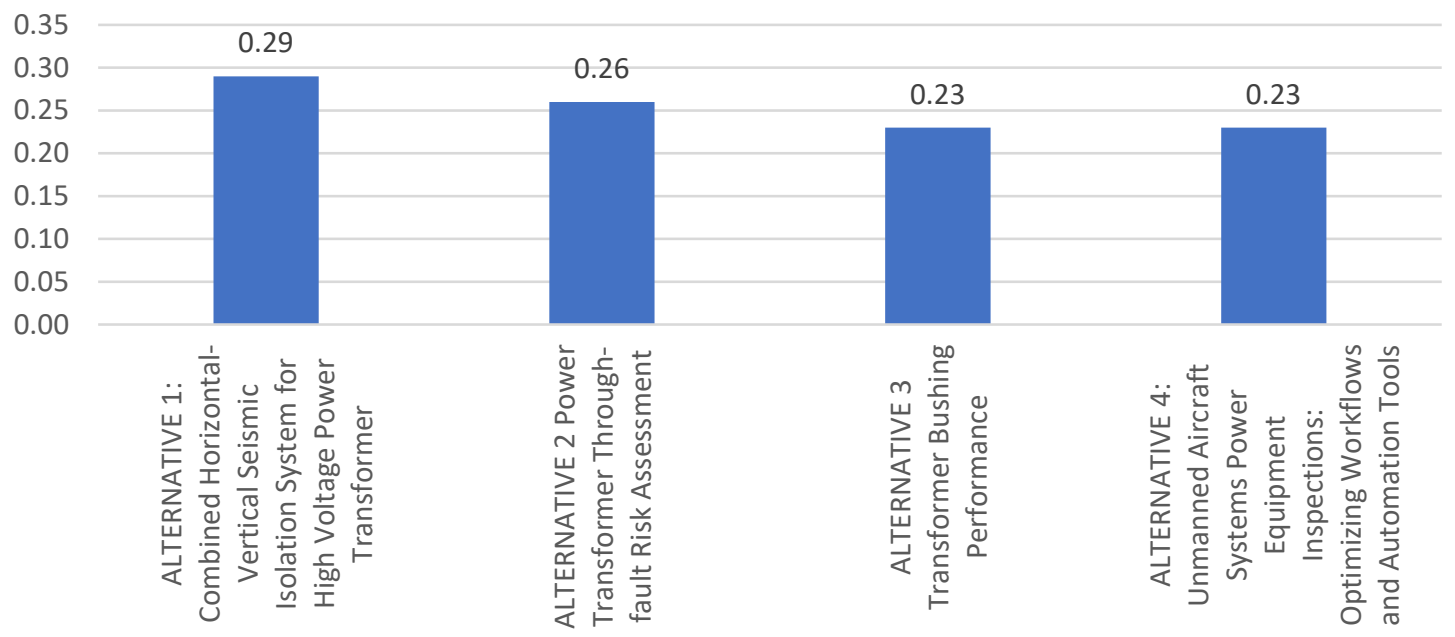

Figure 55: Relative Importance of Alternatives Respect to Net Present Value (NPV) Sub-criterion 
According to the results, Alternative 1 scored the most important (29\%) with respect to Net Present Value (NPV). Alternative 2, alternative 3, and alternative 4 followed in importance $(26 \%, 23 \%$, and $23 \%$, respectively).

The inconsistency within each expert is acceptable (all $<0.10)$. There is also no significant level of disagreement among experts (0.089).

\section{Results of Alternatives with Respect to Value-added of Target Products Sub- criterion}

Expert panel EP2 evaluated the relative importance of alternatives with respect to the Value-added of Target Products sub-criterion using the research instrument RI4. The arithmetic means of experts' judgments for the relative importance of considered alternatives are shown in Table 61 and Figure 56 below.

Table 61: Relative Importance of Alternatives Respect to Value-added of Target Products Sub-criterion

\begin{tabular}{|l|c|c|c|c|c|}
\hline $\begin{array}{c}\text { Value-added of } \\
\text { Target } \\
\text { Products }\end{array}$ & $\begin{array}{c}\text { Alternative 1 } \\
\text { Combined } \\
\text { Vorizontal- } \\
\text { Isolation System } \\
\text { for High } \\
\text { Voltage Power } \\
\text { Transformer }\end{array}$ & $\begin{array}{c}\text { Alternative 2 } \\
\text { Transformer } \\
\text { Through- } \\
\text { fault Risk } \\
\text { Assessment }\end{array}$ & $\begin{array}{c}\text { Alternative 3 } \\
\text { Transformer } \\
\text { Bushing } \\
\text { Performance }\end{array}$ & $\begin{array}{c}\text { Alternative 4 } \\
\text { Unmanned } \\
\text { Aircraft Systems } \\
\text { Power Equipment } \\
\text { Inspections: } \\
\text { Optimizing } \\
\text { Workflows and } \\
\text { Automation Tools }\end{array}$ & Inconsistency \\
\hline Expert 26 & 0.12 & 0.35 & 0.26 & 0.26 & 0.00 \\
\hline Expert 8 & 0.37 & 0.36 & 0.16 & 0.11 & 0.03 \\
\hline Expert 18 & 0.38 & 0.21 & 0.34 & 0.08 & 0.01 \\
\hline Expert 7 & 0.12 & 0.25 & 0.16 & 0.46 & 0.05 \\
\hline Expert 21 & 0.41 & 0.17 & 0.16 & 0.26 & 0.03 \\
\hline Expert 9 & 0.18 & 0.23 & 0.30 & 0.29 & 0.06 \\
\hline Expert 2 & 0.38 & 0.21 & 0.23 & 0.18 & 0.01 \\
\hline Expert 15 & 0.31 & 0.32 & 0.32 & 0.05 & 0.00 \\
\hline Mean & 0.28 & 0.26 & 0.24 & 0.21 & \\
\hline Minimum & 0.12 & 0.17 & 0.16 & 0.05 & 0.46 \\
\hline Maximum & 0.41 & 0.36 & 0.34 & 0.13 & \\
\hline Std. Deviation & 0.12 & 0.07 & 0.07 & & \\
\hline Disagreement & & & & & 0.05 \\
\hline
\end{tabular}




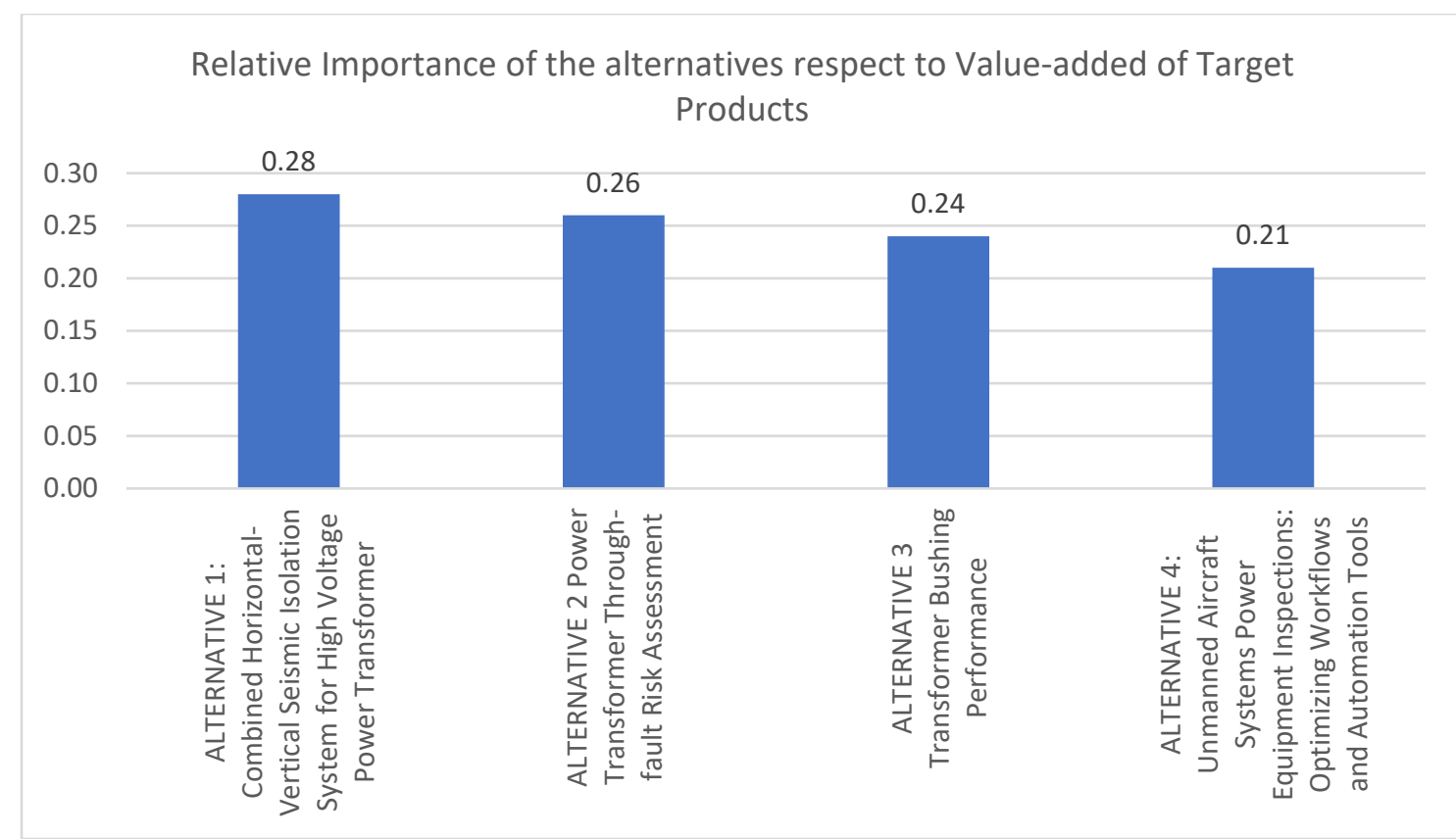

Figure 56: Relative Importance of Alternatives Respect to Value-added of Target Products Sub-criterion

According to the results, Alternative 1 scored the most important (28\%) with respect to the Value-added of Target Products. Alternative 2, Alternative 3, and Alternative 4 followed in importance $(26 \%, 24 \%$, and $21 \%$, respectively).

The inconsistency within each expert is acceptable (all $<0.10)$. There is also no significant level of disagreement among experts (0.095).

\section{Results of Alternatives with Respect to Project Cost Sub-criterion}

Expert panel EP2 evaluated the relative importance of alternatives with respect to the Project cost sub-criterion using the research instrument RI4. The arithmetic means of experts' judgments for the relative importance of considered alternatives are shown in Table 62 and Figure 57 below. 
Table 62: Relative Importance of Alternatives Respect to Project Cost Sub-criterion

\begin{tabular}{|c|c|c|c|c|c|}
\hline & Alternative 1 & Alternative 2 & Alternative 3 & Alternative 4 & \\
\hline Project Cost & $\begin{array}{c}\text { Combined } \\
\text { Horizontal- } \\
\text { Vertical } \\
\text { Seismic } \\
\text { Isolation } \\
\text { System for } \\
\text { High Voltage } \\
\text { Power } \\
\text { Transformer }\end{array}$ & $\begin{array}{c}\text { Power } \\
\text { Transformer } \\
\text { Through-fault } \\
\text { Risk } \\
\text { Assessment }\end{array}$ & $\begin{array}{l}\text { Transformer } \\
\text { Bushing } \\
\text { Performance }\end{array}$ & $\begin{array}{c}\text { Unmanned } \\
\text { Aircraft } \\
\text { Systems Power } \\
\text { Equipment } \\
\text { Inspections: } \\
\text { Optimizing } \\
\text { Workflows } \\
\text { and } \\
\text { Automation } \\
\text { Tools }\end{array}$ & Inconsistency \\
\hline Expert 26 & 0.19 & 0.23 & 0.26 & 0.32 & 0.01 \\
\hline Expert 18 & 0.33 & 0.24 & 0.33 & 0.10 & 0.00 \\
\hline Expert 7 & 0.14 & 0.40 & 0.15 & 0.30 & 0.07 \\
\hline Expert 21 & 0.34 & 0.14 & 0.14 & 0.38 & 0.00 \\
\hline Expert 9 & 0.22 & 0.18 & 0.14 & 0.46 & 0.00 \\
\hline Expert 2 & 0.25 & 0.25 & 0.25 & 0.25 & 0.00 \\
\hline Expert 15 & 0.31 & 0.32 & 0.31 & 0.05 & 0.00 \\
\hline Mean & 0.25 & 0.25 & 0.23 & 0.27 & \\
\hline Minimum & 0.14 & 0.14 & 0.14 & 0.05 & \\
\hline Maximum & 0.34 & 0.40 & 0.33 & 0.46 & \\
\hline $\begin{array}{l}\text { Std. } \\
\text { Deviation }\end{array}$ & 0.07 & 0.08 & 0.08 & 0.14 & \\
\hline Disagreement & & & & & 0.087 \\
\hline
\end{tabular}

\section{Relative Importance of the alternatives respect to Project Cost}

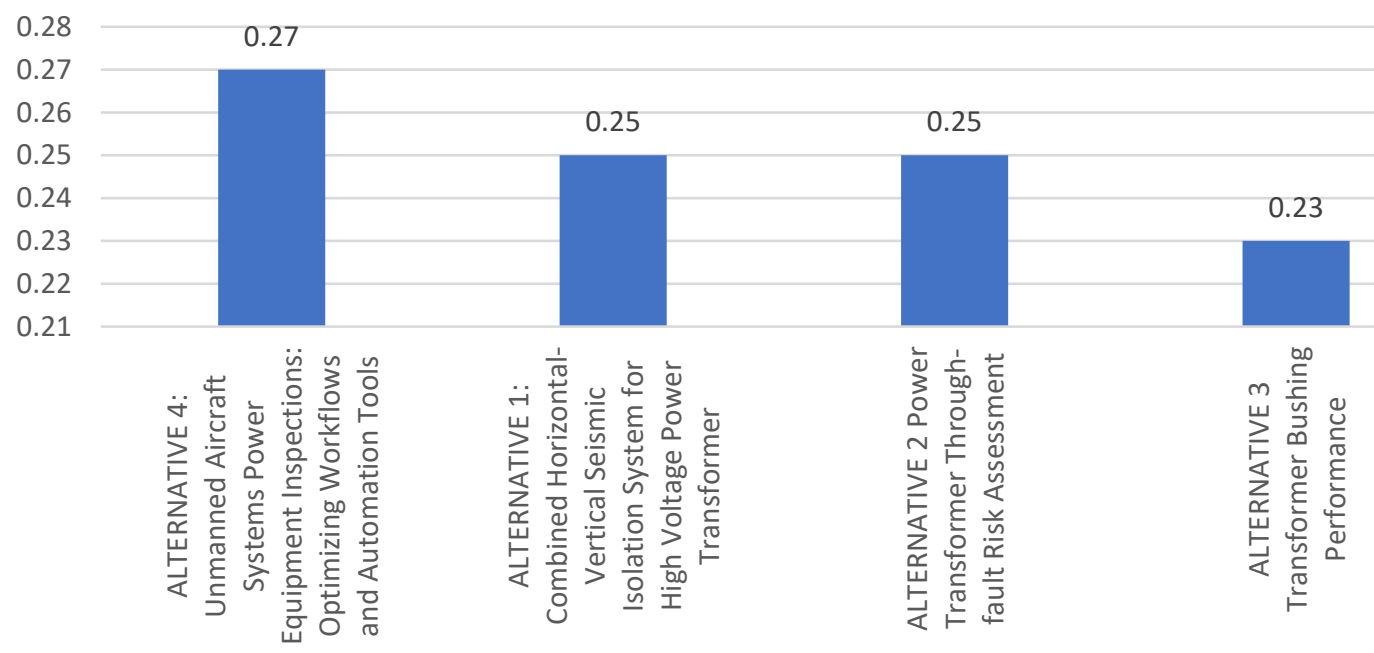

Figure 57: Relative Importance of Alternatives Respect to Project Cost Sub-criterion 
According to the results, Alternative 4 scored the most important (27\%) with respect to Project Cost. Alternative 1, Alternative 2, and Alternative 3 followed in importance $(25 \%, 25 \%$, and $23 \%$, respectively).

The inconsistency within each expert is acceptable (all $<0.10)$. There is also no significant level of disagreement among experts (0.087).

\section{Results of Alternatives with Respect to Economic Risk Sub-criterion}

Expert panel EP2 evaluated the relative importance of alternatives with respect to the Economic Risk sub-criterion using the research instrument RI4. The arithmetic means of experts' judgments for the relative importance of considered alternatives are shown in Table 63 and Figure 58 below.

Table 63: Relative Importance of Alternatives Respect to Economic Risk Sub-criterion

\begin{tabular}{|l|c|c|c|c|c|}
\hline \multicolumn{1}{|c|}{$\begin{array}{c}\text { Economic } \\
\text { Risk }\end{array}$} & $\begin{array}{c}\text { Alternative 1 } \\
\text { Combined } \\
\text { Horizontal- } \\
\text { Vertical } \\
\text { Seismic } \\
\text { Isolation } \\
\text { System for } \\
\text { High Voltage } \\
\text { Power } \\
\text { Transformer }\end{array}$ & $\begin{array}{c}\text { Alternative 2 } \\
\text { Transformer } \\
\text { Through- } \\
\text { fault Risk } \\
\text { Assessment }\end{array}$ & $\begin{array}{c}\text { Alternative 3 } \\
\text { Transformer } \\
\text { Bushing } \\
\text { Performance }\end{array}$ & $\begin{array}{c}\text { Alternative 4 } \\
\text { Unmanned } \\
\text { Aircraft } \\
\text { Systems Power } \\
\text { Equipment } \\
\text { Inspections: } \\
\text { Optimizing } \\
\text { Workflows and } \\
\text { Automation } \\
\text { Tools }\end{array}$ & Inconsistency \\
\hline Expert 26 & 0.49 & 0.16 & 0.20 & 0.15 & 0.02 \\
\hline Expert 8 & 0.29 & 0.18 & 0.44 & 0.09 & 0.04 \\
\hline Expert 18 & 0.35 & 0.24 & 0.34 & 0.08 & 0.01 \\
\hline Expert 7 & 0.19 & 0.35 & 0.37 & 0.09 & 0.05 \\
\hline Expert 21 & 0.48 & 0.12 & 0.15 & 0.25 & 0.07 \\
\hline Expert 9 & 0.24 & 0.24 & 0.16 & 0.36 & 0.02 \\
\hline Expert 2 & 0.25 & 0.25 & 0.25 & 0.25 & 0.00 \\
\hline Expert 15 & 0.31 & 0.32 & 0.32 & 0.05 & 0.00 \\
\hline Mean & 0.33 & 0.23 & 0.28 & 0.17 & 0.092 \\
\hline Minimum & 0.19 & 0.12 & 0.15 & 0.05 & \\
\hline Maximum & 0.49 & 0.35 & 0.44 & 0.36 & \\
\hline Std. Deviation & 0.10 & 0.07 & 0.10 & 0.10 & \\
\hline Disagreement & & & & & \\
\hline
\end{tabular}




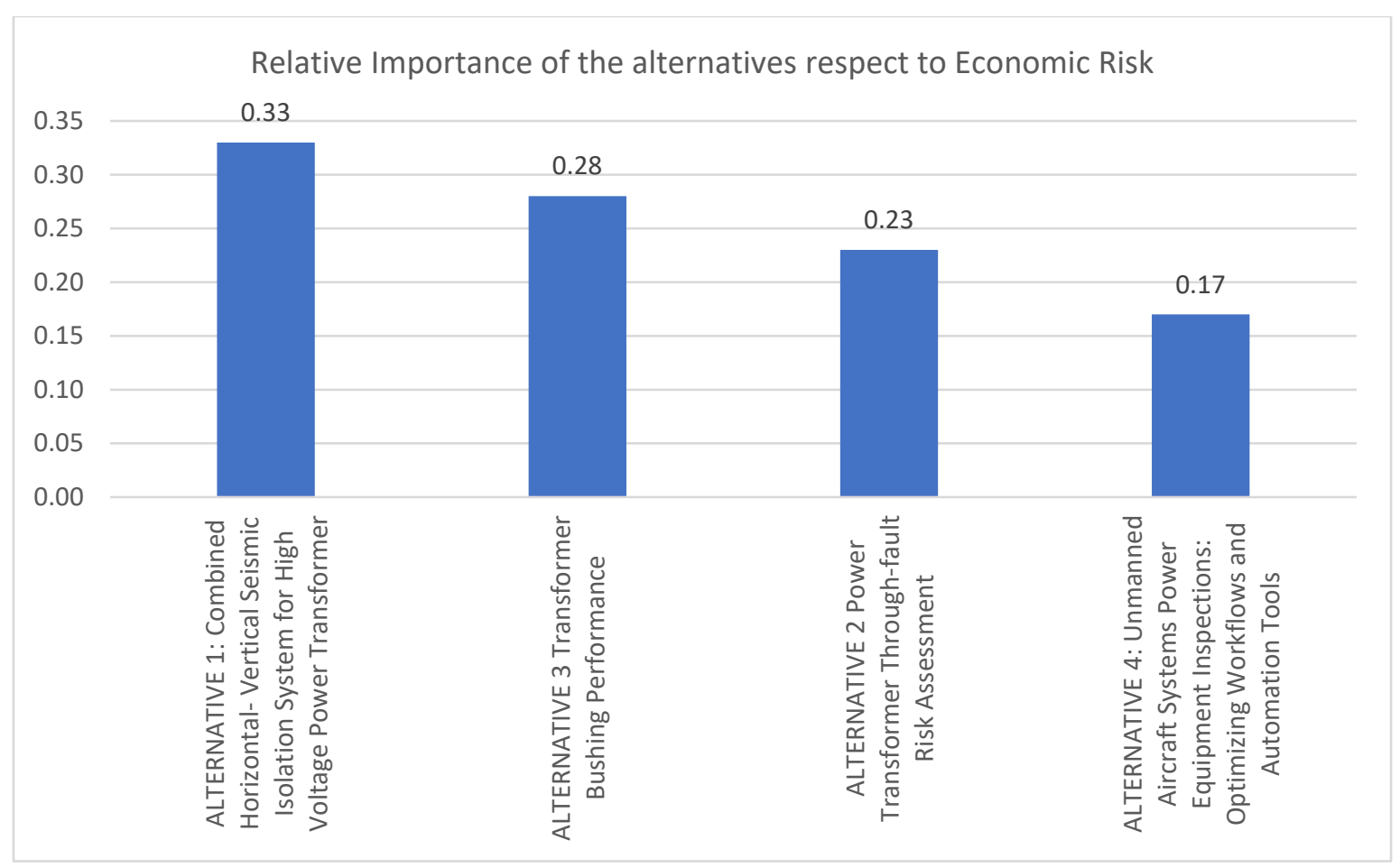

Figure 58: Relative Importance of Alternatives Respect to Economic Risk Sub-criterion

According to the results, Alternative 1 scored the most important (33\%) with respect to Economic Risk. Alternative 3, Alternative 2, and Alternative 4 followed in importance $(28 \%, 23 \%$, and $17 \%$, respectively).

The inconsistency within each expert is acceptable $($ all $<0.10)$. There is also no significant level of disagreement among experts (0.092).

\section{Results of Alternatives with Respect to Economic Regulations Sub-criterion}

Expert panel EP2 evaluated the relative importance of alternatives with respect to the Economic Regulations sub-criterion using the research instrument RI4. The arithmetic means of experts' judgments for the relative importance of considered alternatives are shown in Table 64 and Figure 59 below. 
Table 64: Relative Importance of Alternatives Respect to Economic Regulations Sub-criterion

\begin{tabular}{|c|c|c|c|c|c|}
\hline & Alternative 1 & Alternative 2 & Alternative 3 & Alternative 4 & \\
\hline $\begin{array}{c}\text { Economic } \\
\text { Regulations }\end{array}$ & $\begin{array}{c}\text { Combined } \\
\text { Horizontal- } \\
\text { Vertical } \\
\text { Seismic } \\
\text { Isolation } \\
\text { System for } \\
\text { High Voltage } \\
\text { Power } \\
\text { Transformer }\end{array}$ & $\begin{array}{c}\text { Power } \\
\text { Transformer } \\
\text { Through- } \\
\text { fault Risk } \\
\text { Assessment }\end{array}$ & $\begin{array}{l}\text { Transformer } \\
\text { Bushing } \\
\text { Performance }\end{array}$ & $\begin{array}{c}\text { Unmanned } \\
\text { Aircraft } \\
\text { Systems } \\
\text { Power } \\
\text { Equipment } \\
\text { Inspections: } \\
\text { Optimizing } \\
\text { Workflows } \\
\text { and } \\
\text { Automation } \\
\text { Tools }\end{array}$ & Inconsistency \\
\hline Expert 19 & 0.17 & 0.26 & 0.17 & 0.40 & 0.00 \\
\hline Expert 11 & 0.25 & 0.22 & 0.20 & 0.33 & 0.00 \\
\hline Expert 25 & 0.45 & 0.23 & 0.24 & 0.09 & 0.07 \\
\hline Expert 10 & 0.28 & 0.22 & 0.22 & 0.28 & 0.03 \\
\hline Expert 14 & 0.27 & 0.27 & 0.15 & 0.31 & 0.01 \\
\hline Expert 13 & 0.20 & 0.22 & 0.25 & 0.34 & 0.01 \\
\hline Mean & 0.27 & 0.24 & 0.21 & 0.29 & \\
\hline Minimum & 0.17 & 0.22 & 0.15 & 0.09 & \\
\hline Maximum & 0.45 & 0.27 & 0.25 & 0.40 & \\
\hline Std. Deviation & 0.09 & 0.02 & 0.04 & 0.10 & \\
\hline Disagreement & & & & & 0.055 \\
\hline
\end{tabular}

Relative Importance of the alternatives respect to Economic Regulations

\begin{tabular}{|c|c|c|c|c|}
\hline $\begin{array}{l}0.35 \\
0.30\end{array}$ & 0.29 & 0.27 & & \\
\hline 0.25 & & & 0.24 & 0,21 \\
\hline 0.20 & & & & \\
\hline 0.15 & & & & \\
\hline 0.10 & 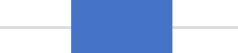 & & & \\
\hline 0.05 & & & & \\
\hline 0.00 & 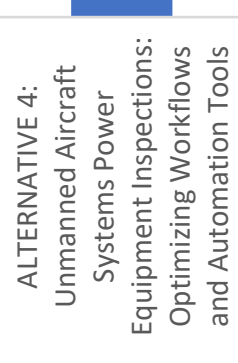 & 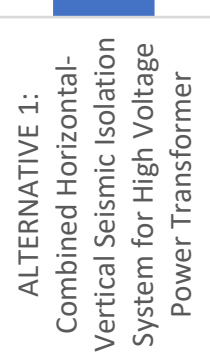 & 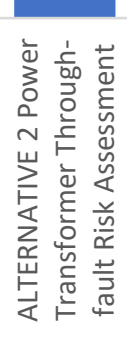 & 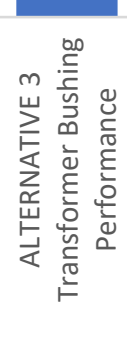 \\
\hline
\end{tabular}

Figure 59: Relative Importance of Alternatives Respect to Economic regulations Sub-criterion 
According to the results, Alternative 4 scored the most important (29\%) with respect to Economic Regulations sub-criterion. Alternative 1, Alternative 2, and Alternative 3 followed in importance $(27 \%, 24 \%$, and 21\%, respectively.

The inconsistency within each expert is acceptable (all $<0.10)$. There is also no significant level of disagreement among experts $(0.055)$.

\section{Results of Alternatives with Respect to Environmental policy Sub-criterion}

Expert panel EP2 evaluated the relative importance of alternatives with respect to the Environmental Policy sub-criterion using the research instrument RI4. The arithmetic means of experts' judgments for the relative importance of considered alternatives are shown in Table 65 and Figure 60 below.

Table 65: Relative Importance of Alternatives Respect to Environmental Policy Sub-criterion

\begin{tabular}{|c|c|c|c|c|c|}
\hline & Alternative 1 & Alternative 2 & Alternative 3 & Alternative 4 & \\
\hline $\begin{array}{c}\text { Environmenta } \\
\text { I policy }\end{array}$ & $\begin{array}{c}\text { Combined } \\
\text { Horizontal- } \\
\text { Vertical } \\
\text { Seismic } \\
\text { Isolation } \\
\text { System for } \\
\text { High Voltage } \\
\text { Power } \\
\text { Transformer } \\
\end{array}$ & $\begin{array}{c}\text { Power } \\
\text { Transformer } \\
\text { Through- } \\
\text { fault Risk } \\
\text { Assessment }\end{array}$ & $\begin{array}{l}\text { Transformer } \\
\text { Bushing } \\
\text { Performance }\end{array}$ & $\begin{array}{c}\text { Unmanned } \\
\text { Aircraft } \\
\text { Systems Power } \\
\text { Equipment } \\
\text { Inspections: } \\
\text { Optimizing } \\
\text { Workflows and } \\
\text { Automation } \\
\text { Tools } \\
\end{array}$ & Inconsistency \\
\hline Expert 19 & 0.00 & 0.33 & 0.00 & 0.67 & 0.05 \\
\hline Expert 11 & 0.36 & 0.26 & 0.16 & 0.22 & 0.04 \\
\hline Expert 25 & 0.35 & 0.26 & 0.28 & 0.11 & 0.08 \\
\hline Expert 10 & 0.28 & 0.22 & 0.22 & 0.28 & 0.03 \\
\hline Expert 14 & 0.31 & 0.25 & 0.13 & 0.31 & 0.01 \\
\hline Expert 13 & 0.22 & 0.22 & 0.22 & 0.33 & 0.00 \\
\hline Mean & 0.25 & 0.26 & 0.17 & 0.32 & \\
\hline Minimum & 0.22 & 0.22 & 0.13 & 0.11 & \\
\hline Maximum & 0.36 & 0.33 & 0.28 & 0.67 & \\
\hline Std. Deviation & 0.12 & 0.04 & 0.09 & 0.17 & \\
\hline Disagreement & & & & & 0.091 \\
\hline
\end{tabular}




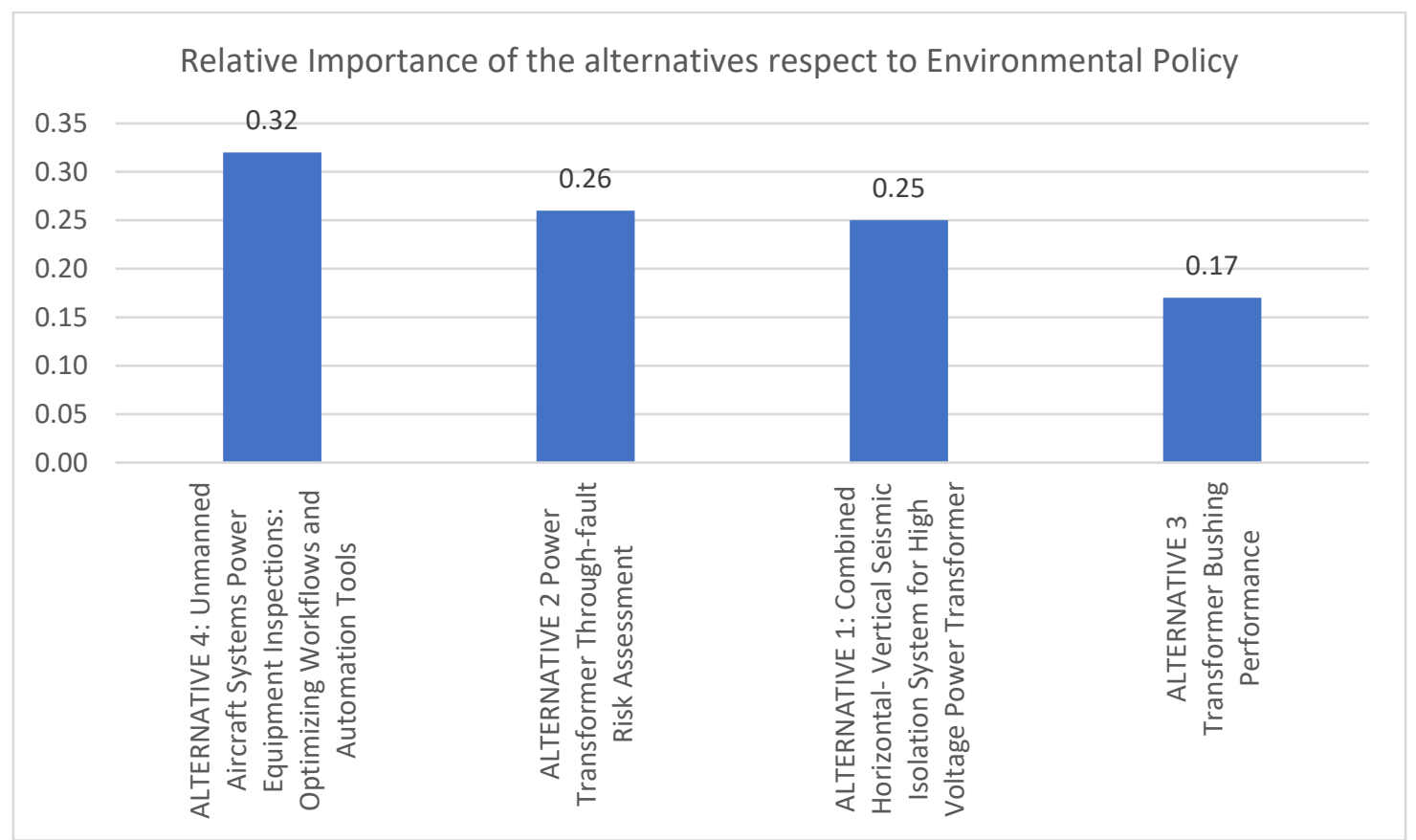

Figure 60: Relative Importance of Alternatives Respect to Environmental Policy Sub-criterion

According to the results, Alternative 4 scored the most important (32\%) with respect to the Environmental policy sub-criterion. Alternative 2, Alternative 1, and Alternative 3 followed in importance $(26 \%, 25 \%$, and $17 \%$, respectively).

The inconsistency within each expert is acceptable $($ all $<0.10)$. There is also no significant level of disagreement among experts (0.091).

\section{Results of Alternatives with Respect to Technical standard policy Sub-criterion}

Expert panel EP2 evaluated the relative importance of alternatives with respect to the Technical standard policy sub-criterion using the research instrument RI4. The arithmetic means of experts' judgments for the relative importance of considered alternatives are shown in Table 66 and Figure 61 below. 
Table 66: Relative Importance of Alternatives Respect to Reliability, Resilience, State Awareness Technical Standards Sub-criterion

\begin{tabular}{|c|c|c|c|c|c|}
\hline & Alternative 1 & Alternative 2 & Alternative 3 & Alternative 4 & \\
\hline $\begin{array}{l}\text { Reliability, } \\
\text { Resilience, } \\
\text { State } \\
\text { Awareness } \\
\text { Technical } \\
\text { Standards }\end{array}$ & $\begin{array}{c}\text { Combined } \\
\text { Horizontal- } \\
\text { Vertical } \\
\text { Seismic } \\
\text { Isolation } \\
\text { System for } \\
\text { High Voltage } \\
\text { Power } \\
\text { Transformer }\end{array}$ & $\begin{array}{c}\text { Power } \\
\text { Transformer } \\
\text { Through- } \\
\text { fault Risk } \\
\text { Assessment }\end{array}$ & $\begin{array}{l}\text { Transformer } \\
\text { Bushing } \\
\text { Performance }\end{array}$ & $\begin{array}{c}\text { Unmanned } \\
\text { Aircraft } \\
\text { Systems Power } \\
\text { Equipment } \\
\text { Inspections: } \\
\text { Optimizing } \\
\text { Workflows and } \\
\text { Automation } \\
\text { Tools }\end{array}$ & Inconsistency \\
\hline Expert 19 & 0.07 & 0.41 & 0.07 & 0.44 & 0.07 \\
\hline Expert 11 & 0.45 & 0.32 & 0.10 & 0.12 & 0.01 \\
\hline Expert 25 & 0.30 & 0.30 & 0.34 & 0.06 & 0.02 \\
\hline Expert 10 & 0.24 & 0.28 & 0.26 & 0.22 & 0.03 \\
\hline Expert 14 & 0.30 & 0.26 & 0.17 & 0.27 & 0.00 \\
\hline Expert 13 & 0.22 & 0.22 & 0.21 & 0.35 & 0.00 \\
\hline Mean & 0.26 & 0.30 & 0.19 & 0.24 & \\
\hline Minimum & 0.07 & 0.22 & 0.07 & 0.06 & \\
\hline Maximum & 0.45 & 0.41 & 0.34 & 0.44 & \\
\hline Std. Deviation & 0.11 & 0.06 & 0.09 & 0.13 & \\
\hline Disagreement & & & & & 0.09 \\
\hline
\end{tabular}

Relative Importance of the alternatives respect to Reliability, Resilience, State Awareness Technical Standards

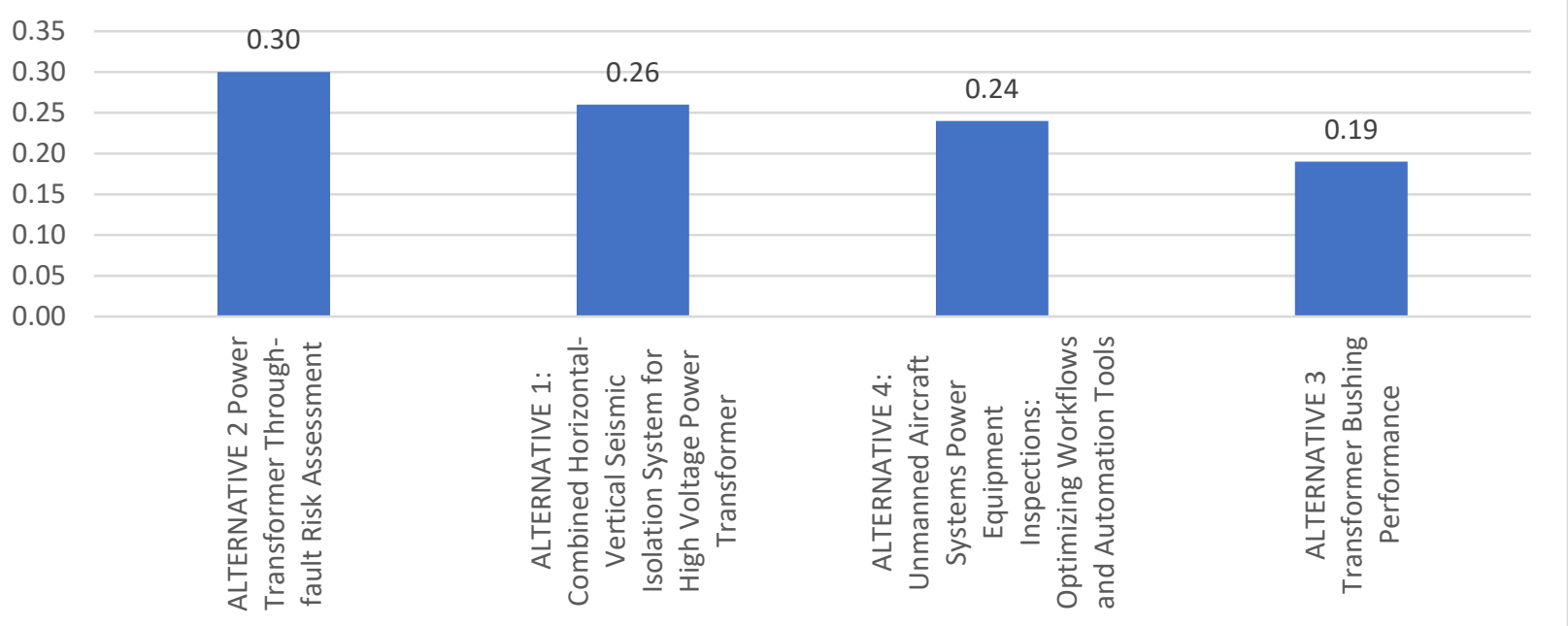

Figure 61: Relative Importance of Alternatives Respect to Reliability, Resilience, State Awareness Technical Standards Sub-criterion

According to the results, Alternative 2 scored the most important (30\%) with respect to Reliability, Resilience, State Awareness Technical Standards sub-criterion. 
Alternative 1, Alternative 4, and Alternative 3 followed in importance $(26 \%, 24 \%$, and $19 \%$, respectively).

The inconsistency within each expert is acceptable (all $<0.10)$. There is also no significant level of disagreement among experts (0.09).

\section{Results of Alternatives with Respect to Acceptance of Stakeholders Sub-criterion}

Expert panel EP2 evaluated the relative importance of alternatives with respect to the Acceptance of Stakeholders sub-criterion using the research instrument RI4. The arithmetic means of experts' judgments for the relative importance of considered alternatives are shown in Table 67 and Figure 62 below.

Table 67: Relative Importance of Alternatives Respect to Acceptance of Stakeholders Sub-criterion

\begin{tabular}{|c|c|c|c|c|c|}
\hline & Alternative 1 & Alternative 2 & Alternative 3 & Alternative 4 & \\
\hline $\begin{array}{l}\text { Acceptance of } \\
\text { Stakeholders }\end{array}$ & $\begin{array}{c}\text { Combined } \\
\text { Horizontal- } \\
\text { Vertical Seismic } \\
\text { Isolation System } \\
\text { for High Voltage } \\
\text { Power } \\
\text { Transformer }\end{array}$ & $\begin{array}{c}\text { Power } \\
\text { Transformer } \\
\text { Through-fault } \\
\text { Risk } \\
\text { Assessment }\end{array}$ & $\begin{array}{l}\text { Transformer } \\
\text { Bushing } \\
\text { Performance }\end{array}$ & $\begin{array}{c}\text { Unmanned } \\
\text { Aircraft Systems } \\
\text { Power Equipment } \\
\text { Inspections: } \\
\text { Optimizing } \\
\text { Workflows and } \\
\text { Automation Tools }\end{array}$ & Inconsistency \\
\hline Expert 19 & 0.14 & 0.14 & 0.14 & 0.57 & 0.00 \\
\hline Expert 11 & 0.48 & 0.26 & 0.22 & 0.03 & 0.07 \\
\hline Expert 25 & 0.32 & 0.31 & 0.26 & 0.11 & 0.01 \\
\hline Expert 10 & 0.37 & 0.25 & 0.22 & 0.15 & 0.01 \\
\hline Expert 14 & 0.23 & 0.27 & 0.15 & 0.36 & 0.00 \\
\hline Expert 13 & 0.25 & 0.22 & 0.22 & 0.30 & 0.00 \\
\hline Mean & 0.30 & 0.24 & 0.20 & 0.25 & \\
\hline Minimum & 0.14 & 0.14 & 0.14 & 0.03 & \\
\hline Maximum & 0.48 & 0.31 & 0.26 & 0.57 & \\
\hline Std. Deviation & 0.11 & 0.05 & 0.04 & 0.18 & \\
\hline Disagreement & & & & & 0.098 \\
\hline
\end{tabular}


According to the results, Alternative 1 scored the most important (30\%) with respect to Reliability, Resilience, State Awareness Technical Standards sub-criterion. Alternative 4, Alternative 2, and Alternative 3 followed in importance $(25 \%, 24 \%$, and $20 \%$, respectively).

The inconsistency within each expert is acceptable (all $<0.10)$. There is also no significant level of disagreement among experts (0.098).

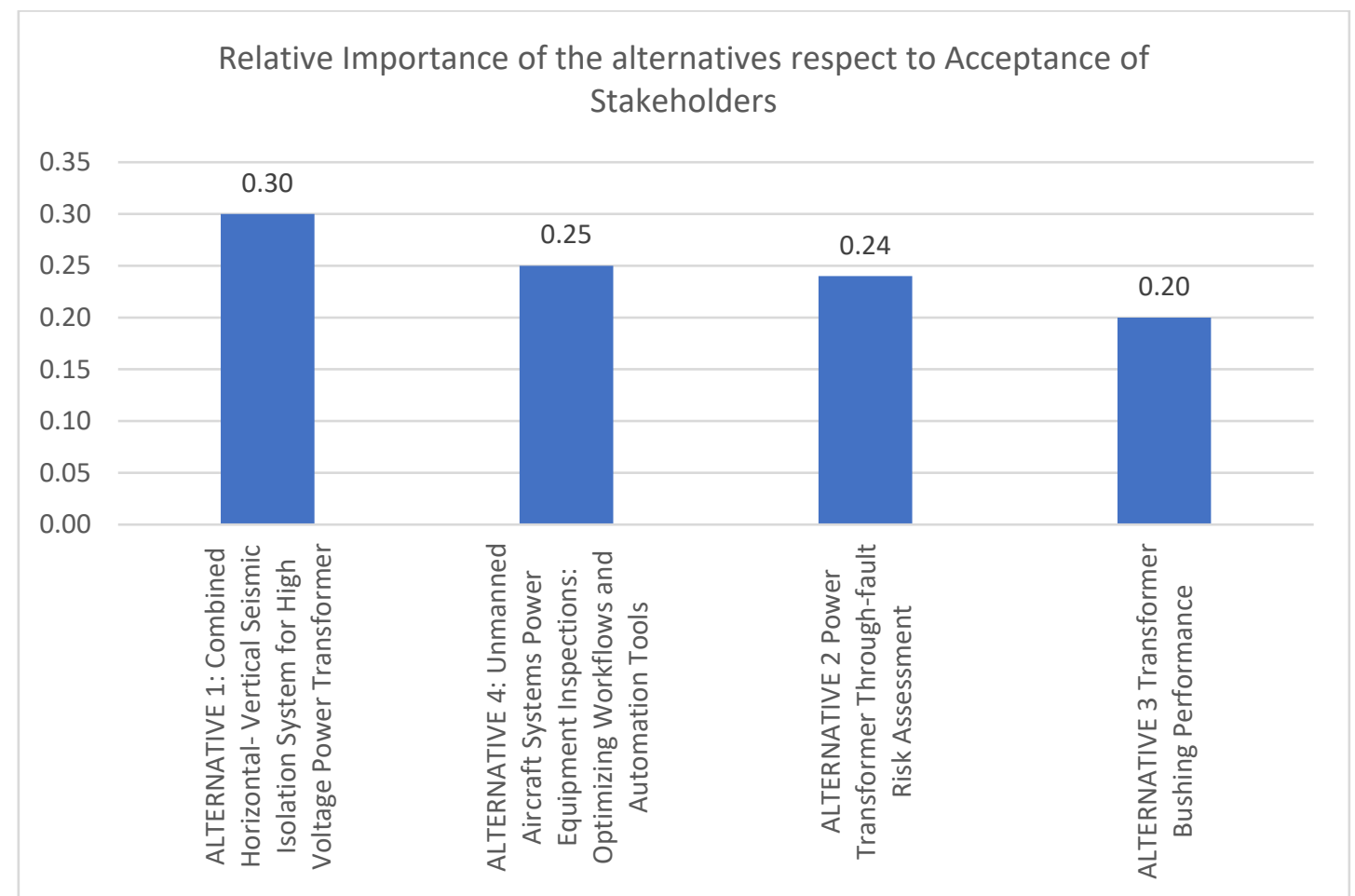

Figure 62: Relative Importance of Alternatives with Respect to Acceptance of Stakeholders Sub-criterion

\section{Results of Alternatives with Respect to Power Quality Standards Sub-criterion}

Expert panel EP2 evaluated the relative importance of alternatives with respect to the Power Quality standards sub-criterion using the research instrument RI4. The arithmetic means of experts' judgments for the relative importance of considered alternatives are shown in Table 68 and Figure 63 below. 
Table 68: Relative Importance of Alternatives Respect to Power Quality Standards Sub-criterion

\begin{tabular}{|c|c|c|c|c|c|}
\hline & Alternative 1 & Alternative 2 & Alternative 3 & Alternative 4 & \\
\hline $\begin{array}{c}\text { Power } \\
\text { Quality } \\
\text { Standards }\end{array}$ & $\begin{array}{c}\text { Combined } \\
\text { Horizontal- } \\
\text { Vertical } \\
\text { Seismic } \\
\text { Isolation } \\
\text { System for } \\
\text { High Voltage } \\
\text { Power } \\
\text { Transformer }\end{array}$ & $\begin{array}{c}\text { Power } \\
\text { Transformer } \\
\text { Through- } \\
\text { fault Risk } \\
\text { Assessment }\end{array}$ & $\begin{array}{l}\text { Transformer } \\
\text { Bushing } \\
\text { Performance }\end{array}$ & $\begin{array}{c}\text { Unmanned } \\
\text { Aircraft } \\
\text { Systems Power } \\
\text { Equipment } \\
\text { Inspections: } \\
\text { Optimizing } \\
\text { Workflows } \\
\text { and } \\
\text { Automation } \\
\text { Tools }\end{array}$ & Inconsistency \\
\hline Expert 19 & 0.05 & 0.50 & 0.05 & 0.40 & 0.00 \\
\hline Expert 11 & 0.26 & 0.32 & 0.31 & 0.11 & 0.01 \\
\hline Expert 25 & 0.33 & 0.38 & 0.19 & 0.10 & 0.06 \\
\hline Expert 10 & 0.37 & 0.27 & 0.21 & 0.15 & 0.00 \\
\hline Expert 14 & 0.27 & 0.25 & 0.15 & 0.33 & 0.00 \\
\hline Expert 13 & 0.22 & 0.22 & 0.22 & 0.33 & 0.00 \\
\hline Mean & 0.25 & 0.32 & 0.19 & 0.24 & \\
\hline Minimum & 0.05 & 0.22 & 0.05 & 0.10 & \\
\hline Maximum & 0.37 & 0.50 & 0.31 & 0.40 & \\
\hline Std. Deviation & 0.10 & 0.09 & 0.08 & 0.12 & \\
\hline Disagreement & & & & & 0.093 \\
\hline
\end{tabular}

\section{Relative Importance of the alternatives respect to Power Quality Standards}

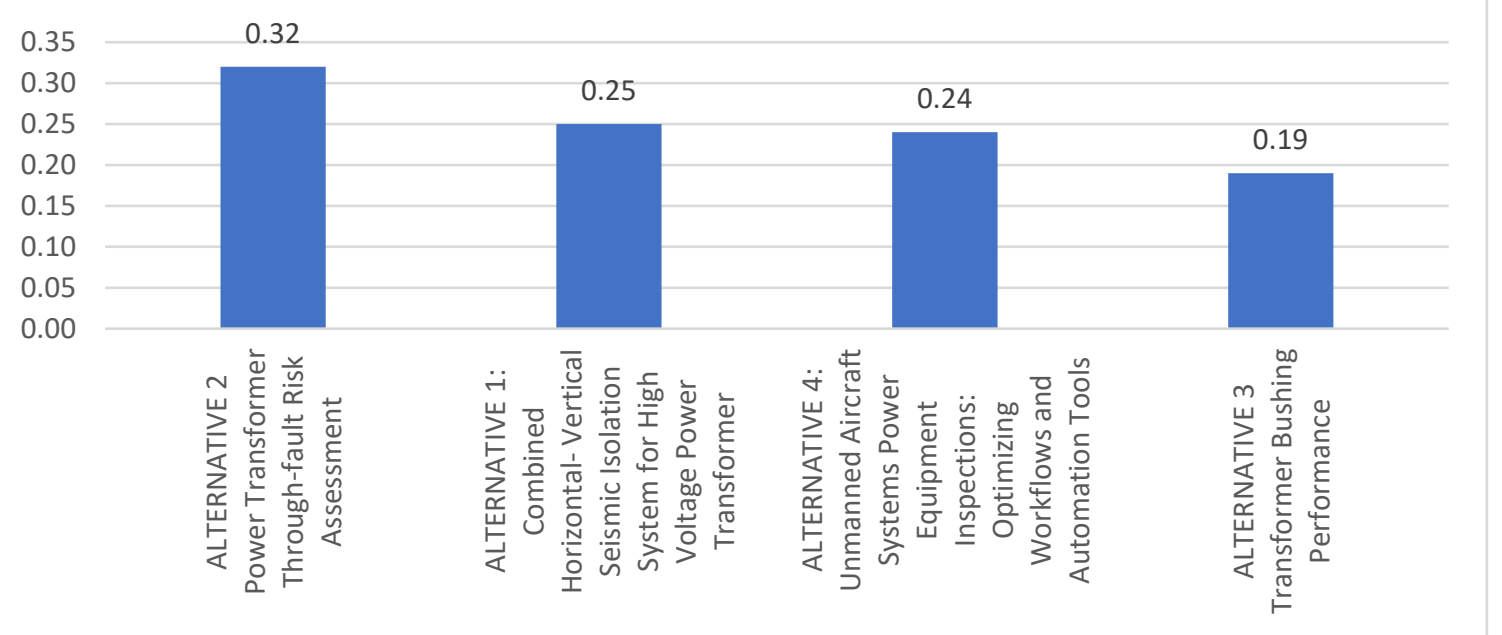

Figure 63: Relative Importance of Alternatives with Respect to Power Quality Standards Sub-criterion 
According to the results, Alternative 2 scored the most important (32\%) with respect to the Power Quality Standards sub-criterion. Alternative 1, Alternative 4, and Alternative 3 followed in importance (25\%, 24\%, and 19\%, respectively).

The inconsistency within each expert is acceptable (all $<0.10)$. There is also no significant level of disagreement among experts (0.093).

Table 69: Summary of Weights / Importance of Alternatives with Respect to Each Criterion

\begin{tabular}{|c|c|c|c|c|c|}
\hline \multirow[b]{2}{*}{ Criteria } & \multirow[b]{2}{*}{ Sub-criteria } & $\begin{array}{c}\text { Alternative } \\
\quad 1\end{array}$ & $\begin{array}{l}\text { Alternative } \\
\quad 2\end{array}$ & $\begin{array}{c}\text { Alternative } \\
\mathbf{3}\end{array}$ & $\begin{array}{c}\text { Alternative } \\
4\end{array}$ \\
\hline & & $\begin{array}{c}\text { Combined } \\
\text { Horizontal- } \\
\text { Vertical } \\
\text { Seismic } \\
\text { Isolation } \\
\text { System for } \\
\text { High } \\
\text { Voltage } \\
\text { Power } \\
\text { Transformer }\end{array}$ & $\begin{array}{c}\text { Power } \\
\text { Transformer } \\
\text { Through- } \\
\text { fault Risk } \\
\text { Assessment }\end{array}$ & $\begin{array}{l}\text { Transformer } \\
\text { Bushing } \\
\text { Performance }\end{array}$ & $\begin{array}{c}\text { Unmanned } \\
\text { Aircraft } \\
\text { Systems } \\
\text { Power } \\
\text { Equipment } \\
\text { Inspections: } \\
\text { Optimizing } \\
\text { Workflows } \\
\text { and } \\
\text { Automation } \\
\text { Tools }\end{array}$ \\
\hline \multirow{5}{*}{ Technical } & $\begin{array}{l}\text { Technical } \\
\text { success }\end{array}$ & 0.30 & 0.31 & 0.18 & 0.21 \\
\hline & $\begin{array}{l}\text { Existence of } \\
\text { required } \\
\text { competence }\end{array}$ & 0.31 & 0.27 & 0.24 & 0.19 \\
\hline & $\begin{array}{l}\text { Availability of } \\
\text { resources }\end{array}$ & 0.22 & 0.34 & 0.24 & 0.20 \\
\hline & $\begin{array}{l}\text { Applicability to } \\
\text { other products } \\
\text { and processes }\end{array}$ & 0.31 & 0.26 & 0.23 & 0.20 \\
\hline & $\begin{array}{l}\text { Technology } \\
\text { readiness }\end{array}$ & 0.32 & 0.30 & 0.24 & 0.14 \\
\hline \multirow{5}{*}{ Market } & $\begin{array}{l}\text { Potential size of } \\
\text { market }\end{array}$ & 0.29 & 0.22 & 0.28 & 0.21 \\
\hline & Time to market & 0.32 & 0.24 & 0.26 & 0.19 \\
\hline & $\begin{array}{l}\text { Additional } \\
\text { (variety) } \\
\text { applications } \\
\text { opened }\end{array}$ & 0.30 & 0.25 & 0.21 & 0.24 \\
\hline & Market risk & 0.23 & 0.27 & 0.22 & 0.28 \\
\hline & System Planning & 0.30 & 0.26 & 0.21 & 0.22 \\
\hline Organizational & $\begin{array}{l}\text { Research staff } \\
\text { availability }\end{array}$ & 0.31 & 0.31 & 0.20 & 0.18 \\
\hline
\end{tabular}




\begin{tabular}{|c|c|c|c|c|c|}
\hline \multirow{6}{*}{ Criteria } & & $\begin{array}{c}\text { Alternative } \\
1\end{array}$ & $\begin{array}{c}\text { Alternative } \\
2\end{array}$ & $\begin{array}{c}\text { Alternative } \\
\mathbf{3}\end{array}$ & $\begin{array}{c}\text { Alternative } \\
4\end{array}$ \\
\hline & Sub-criteria & $\begin{array}{c}\text { Combined } \\
\text { Horizontal- } \\
\text { Vertical } \\
\text { Seismic } \\
\text { Isolation } \\
\text { System for } \\
\text { High } \\
\text { Voltage } \\
\text { Power } \\
\text { Transformer }\end{array}$ & $\begin{array}{c}\text { Power } \\
\text { Transformer } \\
\text { Through- } \\
\text { fault Risk } \\
\text { Assessment }\end{array}$ & $\begin{array}{l}\text { Transformer } \\
\text { Bushing } \\
\text { Performance }\end{array}$ & $\begin{array}{c}\text { Unmanned } \\
\text { Aircraft } \\
\text { Systems } \\
\text { Power } \\
\text { Equipment } \\
\text { Inspections: } \\
\text { Optimizing } \\
\text { Workflows } \\
\text { and } \\
\text { Automation } \\
\text { Tools }\end{array}$ \\
\hline & $\begin{array}{l}\text { Knowledge/skill } \\
\text { availability }\end{array}$ & 0.30 & 0.28 & 0.18 & 0.24 \\
\hline & $\begin{array}{l}\text { Competence and } \\
\text { experience on } \\
\text { similar projects }\end{array}$ & 0.26 & 0.27 & 0.17 & 0.30 \\
\hline & Strategic fit & 0.29 & 0.27 & 0.20 & 0.24 \\
\hline & $\begin{array}{l}\text { Available } \\
\text { facilities }\end{array}$ & 0.24 & 0.32 & 0.21 & 0.23 \\
\hline \multirow{4}{*}{ Economic } & $\begin{array}{l}\text { Net present value } \\
(\mathrm{NPV})\end{array}$ & 0.29 & 0.26 & 0.23 & 0.23 \\
\hline & $\begin{array}{l}\text { Value-added of } \\
\text { target products }\end{array}$ & 0.28 & 0.26 & 0.24 & 0.21 \\
\hline & Project cost & 0.25 & 0.25 & 0.23 & 0.27 \\
\hline & Economic risk & 0.33 & 0.23 & 0.28 & 0.17 \\
\hline \multirow{5}{*}{$\begin{array}{c}\text { External/ } \\
\text { Regulation/ } \\
\text { Environmental }\end{array}$} & $\begin{array}{l}\text { Economic } \\
\text { regulations }\end{array}$ & 0.27 & 0.24 & 0.21 & 0.29 \\
\hline & $\begin{array}{l}\text { Environmental } \\
\text { policy }\end{array}$ & 0.25 & 0.26 & 0.17 & 0.32 \\
\hline & $\begin{array}{l}\text { Reliability, } \\
\text { resilience, state } \\
\text { Awareness } \\
\text { technical } \\
\text { standards }\end{array}$ & 0.26 & 0.30 & 0.19 & 0.24 \\
\hline & $\begin{array}{l}\text { Acceptance of } \\
\text { stakeholders }\end{array}$ & 0.30 & 0.24 & 0.20 & 0.25 \\
\hline & $\begin{array}{l}\text { Power Quality } \\
\text { standards }\end{array}$ & 0.25 & 0.32 & 0.19 & 0.24 \\
\hline
\end{tabular}




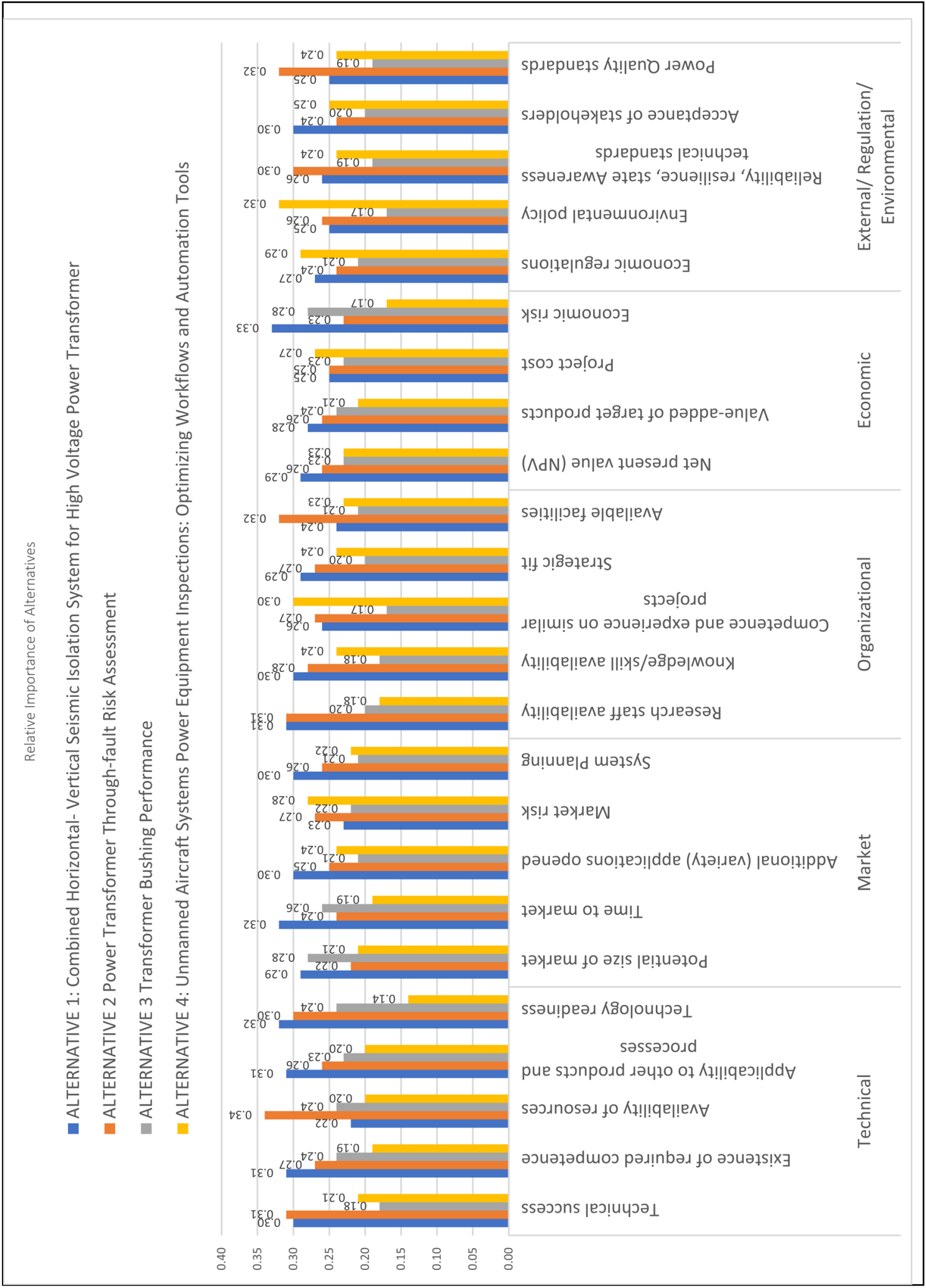

Figure 64: Summary of Weights / Importance of Alternatives with Respect to Each Criterion 
The relative importance of alternatives' respects to each sub-criterion shows that the significance of each alternative follows logical order with respect to criteria and subcriteria. Alternative 1 has the highest weight in most of the sub-criteria. Alternative 1 ranks second in the cases compared with Alternative 2 in those instances of comparing relatively to the sub-criteria Availability of Resources (Technical), Available Facilities (Organizational), Resilience, State Awareness Technical Standards (External / Regulation /

Environmental), and Power Quality Standards (External / Regulation/ Environmental). This shows that Alternative 2, which focused on a general risk assessment of transformers, provides a higher impact for protecting the stability of the system compared with Alternative 1, which is focused on protecting transformers from seismic events. On the other hand, Alternatives 3 and 4 are ranked with very close weights in each sub-criterion.

\subsubsection{Final Model Weights / Importance of Alternatives with respect to Mission}

Here is presented the final result of the importance of alternatives with respect to the mission. Overall, there is not a remarkable difference among the alternatives; however, the importance values of Alternative 1 (Combined Horizontal- Vertical Seismic Isolation System for High Voltage Power Transformer) is the most important (28\%). It was found that Alternative 3 (Transformer Bushing Performance) has the lowest value $(21 \%)$. Additionally, the values of disagreement (0.00) and the inconsistency (0.09) are acceptable. 
Table 70: Final Model Weights / Importance of Alternatives with respect to Mission

\begin{tabular}{|c|c|c|c|c|c|}
\hline & Alternative 1 & Alternative 2 & Alternative 3 & Alternative 4 & \\
\hline $\begin{array}{l}\text { R\&D Project } \\
\text { Selection in } \\
\text { Electric } \\
\text { Transmission } \\
\text { Sector }\end{array}$ & $\begin{array}{c}\text { Combined } \\
\text { Horizontal- } \\
\text { Vertical } \\
\text { Seismic } \\
\text { Isolation } \\
\text { System for } \\
\text { High Voltage } \\
\text { Power } \\
\text { Transformer } \\
\end{array}$ & $\begin{array}{c}\text { Power } \\
\text { Transformer } \\
\text { Through- } \\
\text { fault Risk } \\
\text { Assessment }\end{array}$ & $\begin{array}{l}\text { Transformer } \\
\text { Bushing } \\
\text { Performance }\end{array}$ & $\begin{array}{c}\text { Unmanned } \\
\text { Aircraft } \\
\text { Systems Power } \\
\text { Equipment } \\
\text { Inspections: } \\
\text { Optimizing } \\
\text { Workflows and } \\
\text { Automation } \\
\text { Tools } \\
\end{array}$ & Inconsistency \\
\hline Composite & 0.28 & 0.27 & 0.21 & 0.23 & 0.09 \\
\hline Mean & 0.28 & 0.27 & 0.21 & 0.23 & \\
\hline Minimum & 0.28 & 0.27 & 0.21 & 0.23 & \\
\hline Maximum & 0.28 & 0.27 & 0.21 & 0.23 & \\
\hline Std. Deviation & 0 & 0 & 0 & 0 & \\
\hline Disagreement & & & & & 0 \\
\hline
\end{tabular}

\section{Relative Importance of the Alternatives Respect to the Mission}

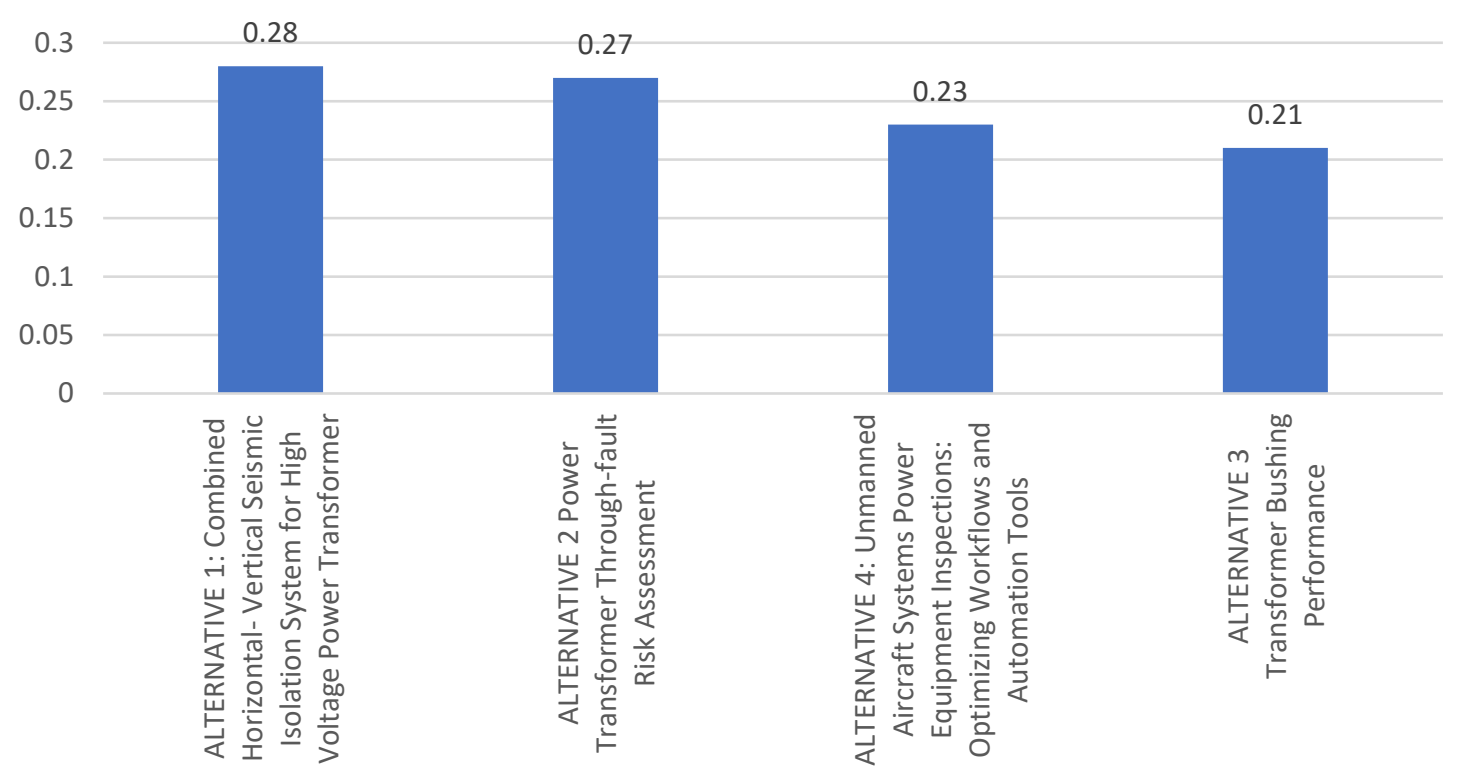

Figure 44: Final Model Weights / Importance of Alternatives with respect to Mission 


\subsubsection{Synthesis of Priorities}

Based on the panel results, synthesis of priorities is calculated for different levels of the decision hierarchy: the relative priority of criteria with respect to the mission, the relative priorities of sub-criteria, and the relative importance of alternatives. At the end, it provided a matrix that shows a summary of the relative values in each level and the respective importance of alternatives with respect to the mission (Table 71).

Table 71: Synthesis of Priorities

\begin{tabular}{|c|c|c|c|c|c|c|}
\hline \multicolumn{2}{|c|}{ Criteria } & \multicolumn{2}{|c|}{ Sub-criteria } & \multicolumn{3}{|c|}{ Alternatives } \\
\hline & Value & & Value & & $\begin{array}{c}\text { Relative } \\
\text { Value }\end{array}$ & $\begin{array}{l}\text { Relative Value } \\
\text { respect to Mission }\end{array}$ \\
\hline \multirow{20}{*}{ Technical } & \multirow{20}{*}{0.19} & \multirow{4}{*}{$\begin{array}{l}\text { Technical } \\
\text { success }\end{array}$} & \multirow{4}{*}{0.27} & Alternative 1 & 0.3 & 0.0154 \\
\hline & & & & Alternative 2 & 0.31 & 0.0159 \\
\hline & & & & Alternative 3 & 0.18 & 0.0092 \\
\hline & & & & Alternative 4 & 0.21 & 0.0108 \\
\hline & & \multirow{4}{*}{$\begin{array}{l}\text { Existence of } \\
\text { required } \\
\text { competence }\end{array}$} & \multirow{4}{*}{0.2} & Alternative 1 & 0.31 & 0.0118 \\
\hline & & & & Alternative 2 & 0.27 & 0.0103 \\
\hline & & & & Alternative 3 & 0.24 & 0.0091 \\
\hline & & & & Alternative 4 & 0.19 & 0.0072 \\
\hline & & \multirow{4}{*}{$\begin{array}{l}\text { Availability } \\
\text { of resources }\end{array}$} & \multirow{4}{*}{0.22} & Alternative 1 & 0.22 & 0.0092 \\
\hline & & & & Alternative 2 & 0.34 & 0.0142 \\
\hline & & & & Alternative 3 & 0.24 & 0.0100 \\
\hline & & & & Alternative 4 & 0.2 & 0.0084 \\
\hline & & \multirow{4}{*}{$\begin{array}{l}\text { Applicability } \\
\text { to other } \\
\text { products and } \\
\text { processes }\end{array}$} & \multirow{4}{*}{0.14} & Alternative 1 & 0.31 & 0.0082 \\
\hline & & & & Alternative 2 & 0.26 & 0.0069 \\
\hline & & & & Alternative 3 & 0.23 & 0.0061 \\
\hline & & & & Alternative 4 & 0.2 & 0.0053 \\
\hline & & \multirow{4}{*}{$\begin{array}{l}\text { Technology } \\
\text { readiness }\end{array}$} & \multirow{4}{*}{0.19} & Alternative 1 & 0.32 & 0.0116 \\
\hline & & & & Alternative 2 & 0.3 & 0.0108 \\
\hline & & & & Alternative 3 & 0.24 & 0.0087 \\
\hline & & & & Alternative 4 & 0.14 & 0.0051 \\
\hline
\end{tabular}




\begin{tabular}{|c|c|c|c|c|c|c|}
\hline \multicolumn{2}{|l|}{ Criteria } & \multicolumn{2}{|c|}{ Sub-criteria } & \multicolumn{3}{|c|}{ Alternatives } \\
\hline & Value & & Value & & $\begin{array}{c}\text { Relative } \\
\text { Value }\end{array}$ & $\begin{array}{c}\text { Relative Value } \\
\text { respect to Mission }\end{array}$ \\
\hline \multirow{20}{*}{ Market } & \multirow{20}{*}{0.15} & \multirow{4}{*}{$\begin{array}{c}\text { Potential size } \\
\text { of market }\end{array}$} & \multirow{4}{*}{0.2} & Alternative 1 & 0.29 & 0.0087 \\
\hline & & & & Alternative 2 & 0.22 & 0.0066 \\
\hline & & & & Alternative 3 & 0.28 & 0.0084 \\
\hline & & & & Alternative 4 & 0.21 & 0.0063 \\
\hline & & \multirow{4}{*}{$\begin{array}{l}\text { Time to } \\
\text { market }\end{array}$} & \multirow{4}{*}{0.22} & Alternative 1 & 0.32 & 0.0106 \\
\hline & & & & Alternative 2 & 0.24 & 0.0079 \\
\hline & & & & Alternative 3 & 0.26 & 0.0086 \\
\hline & & & & Alternative 4 & 0.19 & 0.0063 \\
\hline & & \multirow{4}{*}{$\begin{array}{l}\text { Additional } \\
\text { (variety) } \\
\text { applications } \\
\text { opened }\end{array}$} & \multirow{4}{*}{0.16} & Alternative 1 & 0.3 & 0.0072 \\
\hline & & & & Alternative 2 & 0.25 & 0.0060 \\
\hline & & & & Alternative 3 & 0.21 & 0.0050 \\
\hline & & & & Alternative 4 & 0.24 & 0.0058 \\
\hline & & \multirow{4}{*}{ Market risk } & \multirow{4}{*}{0.2} & Alternative 1 & 0.23 & 0.0069 \\
\hline & & & & Alternative 2 & 0.27 & 0.0081 \\
\hline & & & & Alternative 3 & 0.22 & 0.0066 \\
\hline & & & & Alternative 4 & 0.28 & 0.0084 \\
\hline & & \multirow{4}{*}{$\begin{array}{l}\text { System } \\
\text { Planning }\end{array}$} & \multirow{4}{*}{0.22} & Alternative 1 & 0.3 & 0.0099 \\
\hline & & & & Alternative 2 & 0.26 & 0.0086 \\
\hline & & & & Alternative 3 & 0.21 & 0.0069 \\
\hline & & & & Alternative 4 & 0.22 & 0.0073 \\
\hline \multirow{20}{*}{ Organizational } & \multirow{20}{*}{0.16} & \multirow{4}{*}{$\begin{array}{c}\text { Research } \\
\text { staff } \\
\text { availability }\end{array}$} & \multirow{4}{*}{0.16} & Alternative 1 & 0.31 & 0.0079 \\
\hline & & & & Alternative 2 & 0.31 & 0.0079 \\
\hline & & & & Alternative 3 & 0.2 & 0.0051 \\
\hline & & & & Alternative 4 & 0.18 & 0.0046 \\
\hline & & \multirow{4}{*}{$\begin{array}{c}\text { Knowledge/s } \\
\text { kill } \\
\text { availability }\end{array}$} & \multirow{4}{*}{0.22} & Alternative 1 & 0.3 & 0.0106 \\
\hline & & & & Alternative 2 & 0.28 & 0.0099 \\
\hline & & & & Alternative 3 & 0.18 & 0.0063 \\
\hline & & & & Alternative 4 & 0.24 & 0.0084 \\
\hline & & \multirow{4}{*}{$\begin{array}{c}\text { Competence } \\
\text { and } \\
\text { experience } \\
\text { on similar } \\
\text { projects }\end{array}$} & \multirow{4}{*}{0.2} & Alternative 1 & 0.26 & 0.0083 \\
\hline & & & & Alternative 2 & 0.27 & 0.0086 \\
\hline & & & & Alternative 3 & 0.17 & 0.0054 \\
\hline & & & & Alternative 4 & 0.3 & 0.0096 \\
\hline & & \multirow{4}{*}{ Strategic fit } & \multirow{4}{*}{0.27} & Alternative 1 & 0.29 & 0.0125 \\
\hline & & & & Alternative 2 & 0.27 & 0.0117 \\
\hline & & & & Alternative 3 & 0.2 & 0.0086 \\
\hline & & & & Alternative 4 & 0.24 & 0.0104 \\
\hline & & & & Alternative 1 & 0.24 & 0.0058 \\
\hline & & Available & 0.15 & Alternative 2 & 0.32 & 0.0077 \\
\hline & & facilities & & Alternative 3 & 0.21 & 0.0050 \\
\hline & & & & Alternative 4 & 0.23 & 0.0055 \\
\hline
\end{tabular}




\begin{tabular}{|c|c|c|c|c|c|c|}
\hline \multicolumn{2}{|c|}{ Criteria } & \multicolumn{2}{|c|}{ Sub-criteria } & \multicolumn{3}{|c|}{ Alternatives } \\
\hline & Value & & Value & & $\begin{array}{l}\text { Relative } \\
\text { Value }\end{array}$ & $\begin{array}{l}\text { Relative Value } \\
\text { respect to Mission }\end{array}$ \\
\hline \multirow{16}{*}{ Economic } & \multirow{16}{*}{0.22} & \multirow{4}{*}{$\begin{array}{l}\text { Net present } \\
\text { value (NPV). }\end{array}$} & \multirow{4}{*}{0.23} & Alternative 1 & 0.29 & 0.0147 \\
\hline & & & & Alternative 2 & 0.26 & 0.0132 \\
\hline & & & & Alternative 3 & 0.23 & 0.0116 \\
\hline & & & & Alternative 4 & 0.23 & 0.0116 \\
\hline & & \multirow{4}{*}{$\begin{array}{l}\text { Value-added } \\
\text { of target } \\
\text { products }\end{array}$} & \multirow{4}{*}{0.28} & Alternative 1 & 0.28 & 0.0172 \\
\hline & & & & Alternative 2 & 0.26 & 0.0160 \\
\hline & & & & Alternative 3 & 0.24 & 0.0148 \\
\hline & & & & Alternative 4 & 0.21 & 0.0129 \\
\hline & & \multirow{4}{*}{ Project cost } & \multirow{4}{*}{0.23} & Alternative 1 & 0.25 & 0.0127 \\
\hline & & & & Alternative 2 & 0.25 & 0.0127 \\
\hline & & & & Alternative 3 & 0.23 & 0.0116 \\
\hline & & & & Alternative 4 & 0.27 & 0.0137 \\
\hline & & \multirow{4}{*}{$\begin{array}{l}\text { Economic } \\
\text { risk }\end{array}$} & \multirow{4}{*}{0.26} & Alternative 1 & 0.33 & 0.0189 \\
\hline & & & & Alternative 2 & 0.23 & 0.0132 \\
\hline & & & & Alternative 3 & 0.28 & 0.0160 \\
\hline & & & & Alternative 4 & 0.17 & 0.0097 \\
\hline \multirow{20}{*}{$\begin{array}{c}\text { External/ } \\
\text { Regulation/ } \\
\text { Environmental }\end{array}$} & \multirow{20}{*}{0.27} & \multirow{4}{*}{$\begin{array}{l}\text { Economic } \\
\text { regulations }\end{array}$} & \multirow{4}{*}{0.18} & Alternative 1 & 0.27 & 0.0131 \\
\hline & & & & Alternative 2 & 0.24 & 0.0117 \\
\hline & & & & Alternative 3 & 0.21 & 0.0102 \\
\hline & & & & Alternative 4 & 0.29 & 0.0141 \\
\hline & & \multirow{4}{*}{$\begin{array}{l}\text { Environment } \\
\text { al policy }\end{array}$} & \multirow{4}{*}{0.21} & Alternative 1 & 0.25 & 0.0142 \\
\hline & & & & Alternative 2 & 0.26 & 0.0147 \\
\hline & & & & Alternative 3 & 0.17 & 0.0096 \\
\hline & & & & Alternative 4 & 0.32 & 0.0181 \\
\hline & & \multirow{4}{*}{$\begin{array}{l}\text { Reliability, } \\
\text { resilience, } \\
\text { state } \\
\text { Awareness } \\
\text { technical } \\
\text { standards }\end{array}$} & \multirow{4}{*}{0.23} & Alternative 1 & 0.26 & 0.0161 \\
\hline & & & & Alternative 2 & 0.3 & 0.0186 \\
\hline & & & & Alternative 3 & 0.19 & 0.0118 \\
\hline & & & & Alternative 4 & 0.24 & 0.0149 \\
\hline & & \multirow{4}{*}{$\begin{array}{l}\text { Acceptance } \\
\text { of } \\
\text { stakeholders }\end{array}$} & \multirow{4}{*}{0.16} & Alternative 1 & 0.3 & 0.0130 \\
\hline & & & & Alternative 2 & 0.24 & 0.0104 \\
\hline & & & & Alternative 3 & 0.2 & 0.0086 \\
\hline & & & & Alternative 4 & 0.25 & 0.0108 \\
\hline & & \multirow{4}{*}{$\begin{array}{c}\text { Power } \\
\text { Quality } \\
\text { standards }\end{array}$} & \multirow{4}{*}{0.22} & Alternative 1 & 0.25 & 0.0149 \\
\hline & & & & Alternative 2 & 0.32 & 0.0190 \\
\hline & & & & Alternative 3 & 0.19 & 0.0113 \\
\hline & & & & Alternative 4 & 0.24 & 0.0143 \\
\hline
\end{tabular}


The results of ranking the alternatives are presented in Table 72 which shows that, from higher to lower rank, the alternatives' order is Alternative 1, Alternative 2, Alternative 4, and Alternative 3.

Table 72: Overall Importance of Alternatives with Respect to the Mission

\begin{tabular}{|c|l|c|c|c|}
\hline Alternative & \multicolumn{1}{|c|}{ Alternative Project Title } & Base Values & Rank & Sensitivity Value \\
\hline Alternative 1 & $\begin{array}{l}\text { Combined Horizontal- Vertical } \\
\text { Seismic Isolation System for High } \\
\text { Voltage Power Transformer }\end{array}$ & 0.28 & 1 & 0.28 \\
\hline Alternative 2 & $\begin{array}{l}\text { Power Transformer Through-fault } \\
\text { Risk Assessment }\end{array}$ & 0.27 & 2 & 0.27 \\
\hline Alternative 3 & Transformer Bushing Performance & 0.21 & 4 & 0.21 \\
\hline Alternative 4 & $\begin{array}{l}\text { Unmanned Aircraft Systems Power } \\
\text { Equipment Inspections: Optimizing } \\
\text { Workflows and Automation Tools }\end{array}$ & 0.23 & 3 & 0.23 \\
\hline
\end{tabular}

\subsection{Sensitivity Analysis}

A sensitivity analysis was performed to test the sensitivity of the five criteria. Sensitivity analysis determines the allowable range of each output indicator in order to maintain the priority of sub-factors [235]. As Estep and Abotah[237], [235] use sensitivity analysis; the following results are obtained (Table 73).

The initial importance and order of the values of alternatives with respect to the mission are given by the experts as it was presented above. However, "what if another perspective was evaluated as more important?" [237]. Therefore, four "what if" different scenarios were analyzed. The different scenarios are considered by assigning the value of " 0.96 " to the criterion that dominates, keeping constant the rest of the values of each criterion [237]. 
Table 73 to 83 show the final results and orders of the weights of alternatives based on changes in the values of criteria with dominant values. As it is shown, the changes are not substantial in values (weights); however, the orders have changed, especially for the alternatives considered lower in importance.

Table 73: Sensitivity Analysis with Technical dominant Criterion

\begin{tabular}{|c|c|c|c|c|c|}
\hline Criteria & Technical & Market & Organizational & Economic & $\begin{array}{c}\text { External / Regulation / } \\
\text { Environmental }\end{array}$ \\
\hline Value & 0.96 & 0.01 & 0.01 & 0.01 & 0.01 \\
\hline
\end{tabular}

Table 74: Overall Importance of Alternatives with Respect to the Mission

\begin{tabular}{|c|c|c|c|c|c|}
\hline Alternative & Alternative Project Title & Base Values & Rank & Sensitivity Value & New Rank \\
\hline Alternative 1 & $\begin{array}{l}\text { Combined Horizontal- } \\
\text { Vertical Seismic Isolation } \\
\text { System for High Voltage } \\
\text { Power Transformer }\end{array}$ & 0.28 & 1 & 0.30 & $1-2$ \\
\hline Alternative 2 & $\begin{array}{l}\text { Power Transformer } \\
\text { Through-fault Risk } \\
\text { Assessment }\end{array}$ & 0.27 & 2 & 0.30 & $1-2$ \\
\hline Alternative 3 & $\begin{array}{l}\text { Transformer Bushing } \\
\text { Performance }\end{array}$ & 0.21 & 4 & 0.23 & 3 \\
\hline Alternative 4 & $\begin{array}{l}\text { Unmanned Aircraft } \\
\text { Systems Power Equipment } \\
\text { Inspections: Optimizing } \\
\text { Workflows and } \\
\text { Automation Tools }\end{array}$ & 0.23 & 3 & 0.20 & 4 \\
\hline
\end{tabular}

Table 75: Sensitivity Analysis with Market dominant Criterion

\begin{tabular}{|c|c|c|c|c|c|}
\hline Criteria & Technical & Market & Organizational & Economic & $\begin{array}{c}\text { External/ } \\
\text { Regulation/ } \\
\text { Environmental }\end{array}$ \\
\hline Value & 0.01 & 0.96 & 0.01 & 0.01 & 0.01 \\
\hline
\end{tabular}


Table 76: Overall Importance of Alternatives with Respect to the Mission

\begin{tabular}{|c|l|c|c|c|c|}
\hline Alternative & Alternative Project Title & Base Values & Rank & Sensitivity Value & New Rank \\
\hline Alternative 1 & $\begin{array}{l}\text { Combined Horizontal- } \\
\text { Vertical Seismic Isolation } \\
\text { System for High Voltage } \\
\text { Power Transformer }\end{array}$ & 0.28 & 1 & 0.29 & 1 \\
\hline Alternative 2 & $\begin{array}{l}\text { Power Transformer } \\
\text { Through-fault Risk } \\
\text { Assessment }\end{array}$ & 0.27 & 2 & 0.25 & 2 \\
\hline Alternative 3 & $\begin{array}{l}\text { Transformer Bushing } \\
\text { Performance }\end{array}$ & 0.21 & 4 & 0.24 & 3 \\
\hline & $\begin{array}{l}\text { Unmanned Aircraft } \\
\text { Systems Power Equipment } \\
\text { Inspections: Optimizing } \\
\text { Workflows and } \\
\text { Automation Tools }\end{array}$ & 0.23 & 3 & 0.23 & 4 \\
\hline
\end{tabular}

Table 77: Sensitivity Analysis with Organizational dominant Criterion

\begin{tabular}{|c|c|c|c|c|c|}
\hline Criteria & Technical & Market & Organizational & Economic & $\begin{array}{c}\text { External/ Regulation/ } \\
\text { Environmental }\end{array}$ \\
\hline Value & 0.01 & 0.01 & 0.96 & 0.01 & 0.01 \\
\hline
\end{tabular}

Table 78: Overall Importance of Alternatives with Respect to the Mission

\begin{tabular}{|c|c|c|c|c|c|}
\hline Alternative & Alternative Project Title & Base Values & Rank & Sensitivity Value & New Rank \\
\hline Alternative 1 & $\begin{array}{l}\text { Combined Horizontal- } \\
\text { Vertical Seismic Isolation } \\
\text { System for High Voltage } \\
\text { Power Transformer }\end{array}$ & 0.28 & 1 & 0.28 & 2 \\
\hline Alternative 2 & $\begin{array}{l}\text { Power Transformer } \\
\text { Through-fault Risk } \\
\text { Assessment }\end{array}$ & 0.27 & 2 & 0.29 & 1 \\
\hline Alternative 3 & $\begin{array}{l}\text { Transformer Bushing } \\
\text { Performance }\end{array}$ & 0.21 & 4 & 0.19 & 4 \\
\hline Alternative 4 & $\begin{array}{l}\text { Unmanned Aircraft } \\
\text { Systems Power Equipment } \\
\text { Inspections: Optimizing } \\
\text { Workflows and } \\
\text { Automation Tools }\end{array}$ & 0.23 & 3 & 0.24 & 3 \\
\hline
\end{tabular}

Table 79: Sensitivity Analysis with Economic dominant Criterion

\begin{tabular}{|c|c|c|c|c|c|}
\hline $\begin{array}{c}\text { Criteri } \\
\text { a }\end{array}$ & Technical & Market & $\begin{array}{c}\text { Organization } \\
\text { al }\end{array}$ & $\begin{array}{c}\text { Economi } \\
\text { c }\end{array}$ & $\begin{array}{c}\text { External/ Regulation/ } \\
\text { Environmental }\end{array}$ \\
\hline Value & 0.01 & 0.01 & 0.01 & 0.96 & 0.01 \\
\hline
\end{tabular}


Table 80: Overall Importance of Alternatives with Respect to the Mission

\begin{tabular}{|c|l|c|c|c|c|}
\hline Alternative & Alternative Project Title & Base Values & Rank & Sensitivity Value & New Rank \\
\hline Alternative 1 & $\begin{array}{l}\text { Combined Horizontal- } \\
\text { Vertical Seismic Isolation } \\
\text { System for High Voltage } \\
\text { Power Transformer }\end{array}$ & 0.28 & 1 & 0.29 & 1 \\
\hline Alternative 2 & $\begin{array}{l}\text { Power Transformer } \\
\text { Through-fault Risk } \\
\text { Assessment }\end{array}$ & 0.27 & 2 & 0.25 & 2 \\
\hline Alternative 3 & $\begin{array}{l}\text { Transformer Bushing } \\
\text { Performance }\end{array}$ & 0.21 & 4 & 0.24 & 3 \\
\hline & $\begin{array}{l}\text { Unmanned Aircraft } \\
\text { Systems Power Equipment } \\
\text { Inspections: Optimizing } \\
\text { Workflows and } \\
\text { Automation Tools }\end{array}$ & 0.23 & 3 & 0.22 & 4 \\
\hline
\end{tabular}

Table 81: Sensitivity Analysis with External/ Regulation/ Environmental Dominant Criterion

\begin{tabular}{|c|c|c|c|c|c|}
\hline Criteria & Technical & Market & Organizational & Economic & $\begin{array}{c}\text { External/ } \\
\text { Regulation/ } \\
\text { Environmental }\end{array}$ \\
\hline Value & 0.01 & 0.01 & 0.01 & 0.01 & 0.96 \\
\hline
\end{tabular}

Table 82: Overall Importance of Alternatives with Respect to the Mission

\begin{tabular}{|c|l|c|c|c|c|}
\hline Alternative & Alternative Project Title & Base Values & Rank & Sensitivity Value & New Rank \\
\hline Alternative 1 & $\begin{array}{l}\text { Combined Horizontal- } \\
\text { Vertical Seismic Isolation } \\
\text { System for High Voltage } \\
\text { Power Transformer }\end{array}$ & 0.28 & 1 & 0.26 & 1 \\
\hline Alternative 2 & $\begin{array}{l}\text { Power Transformer } \\
\text { Through-fault Risk } \\
\text { Assessment }\end{array}$ & 0.27 & 2 & 0.28 & 1 \\
\hline Alternative 3 & $\begin{array}{l}\text { Transformer Bushing } \\
\text { Performance }\end{array}$ & 0.21 & 4 & 0.19 & 3 \\
\hline & $\begin{array}{l}\text { Unmanned Aircraft } \\
\text { Systems Power Equipment } \\
\text { Inspections: Optimizing } \\
\text { Workflows and } \\
\text { Automation Tools }\end{array}$ & 0.23 & 3 & 0.27 & 4 \\
\hline
\end{tabular}


Table 83: Summary of Case sensitive Analysis

\begin{tabular}{|c|c|c|c|c|c|c|c|c|c|c|c|c|}
\hline \multirow{3}{*}{ Alternatives } & \multirow{2}{*}{\multicolumn{2}{|c|}{ Base Case }} & \multicolumn{2}{|c|}{ Case 1: } & \multicolumn{2}{|c|}{ Case 2: } & \multicolumn{2}{|c|}{ Case 3: } & \multicolumn{2}{|c|}{ Case 4: } & \multicolumn{2}{|c|}{ Case 5: } \\
\hline & & & \multicolumn{2}{|c|}{$\begin{array}{c}\text { Technical = } \\
0.96 \\
\text { Market }= \\
0.01 \\
\text { Organizational } \\
=0.01 \\
\text { Economic }= \\
0.01 \\
\text { Environmental/ } \\
\text { Regulation = } \\
0.01 \\
\end{array}$} & \multicolumn{2}{|c|}{$\begin{array}{c}\text { Technical = } \\
0.01 \\
\text { Market }= \\
0.96 \\
\text { Organizational } \\
=0.01 \\
\text { Economic = } \\
0.01 \\
\text { Environmental/ } \\
\text { Regulation = } \\
0.01\end{array}$} & \multicolumn{2}{|c|}{$\begin{array}{c}\text { Technical = } \\
0.01 \\
\text { Market }= \\
0.01 \\
\text { Organizational } \\
=0.96 \\
\text { Economic = } \\
0.01 \\
\text { Environmental/ } \\
\text { Regulation = } \\
0.01\end{array}$} & \multicolumn{2}{|c|}{$\begin{array}{c}\text { Technical = } \\
0.01 \\
\text { Market }= \\
0.01 \\
\text { Organizational } \\
=0.01 \\
\text { Economic }= \\
0.96 \\
\text { Environmental/ } \\
\text { Regulation = } \\
0.01\end{array}$} & \multicolumn{2}{|c|}{$\begin{array}{c}\text { Technical = } \\
0.01 \\
\text { Market }= \\
0.01 \\
\text { Organizational } \\
=0.01 \\
\text { Economic = } \\
0.01 \\
\text { Environmental/ } \\
\text { Regulation = } \\
0.96\end{array}$} \\
\hline & $\begin{array}{c}\text { Base } \\
\text { Values }\end{array}$ & $\begin{array}{l}\text { Base } \\
\text { Rank }\end{array}$ & $\begin{array}{c}\text { New } \\
\text { Value }\end{array}$ & $\begin{array}{l}\text { New } \\
\text { Rank }\end{array}$ & $\begin{array}{c}\text { New } \\
\text { Value }\end{array}$ & $\begin{array}{l}\text { New } \\
\text { Rank }\end{array}$ & $\begin{array}{c}\text { New } \\
\text { Value }\end{array}$ & $\begin{array}{l}\text { New } \\
\text { Rank }\end{array}$ & $\begin{array}{c}\text { New } \\
\text { Value }\end{array}$ & $\begin{array}{l}\text { New } \\
\text { Rank }\end{array}$ & $\begin{array}{l}\text { New } \\
\text { Value }\end{array}$ & $\begin{array}{l}\text { New } \\
\text { Rank }\end{array}$ \\
\hline $\begin{array}{c}\text { Alternative } \\
1\end{array}$ & 0.28 & 1 & 0.30 & $1-2$ & 0.29 & 1 & 0.28 & 2 & 0.29 & 1 & 0.26 & $1-2$ \\
\hline $\begin{array}{c}\text { Alternative } \\
2\end{array}$ & 0.27 & 2 & 0.30 & $1-2$ & 0.25 & 2 & 0.29 & 1 & 0.25 & 2 & 0.28 & $1-2$ \\
\hline $\begin{array}{c}\text { Alternative } \\
3\end{array}$ & 0.21 & 4 & 0.23 & 3 & 0.24 & 3 & 0.19 & 4 & 0.24 & 3 & 0.19 & 3 \\
\hline $\begin{array}{c}\text { Alternative } \\
4\end{array}$ & 0.23 & 3 & 0.20 & 4 & 0.23 & 4 & 0.24 & 3 & 0.22 & 4 & 0.27 & 4 \\
\hline
\end{tabular}




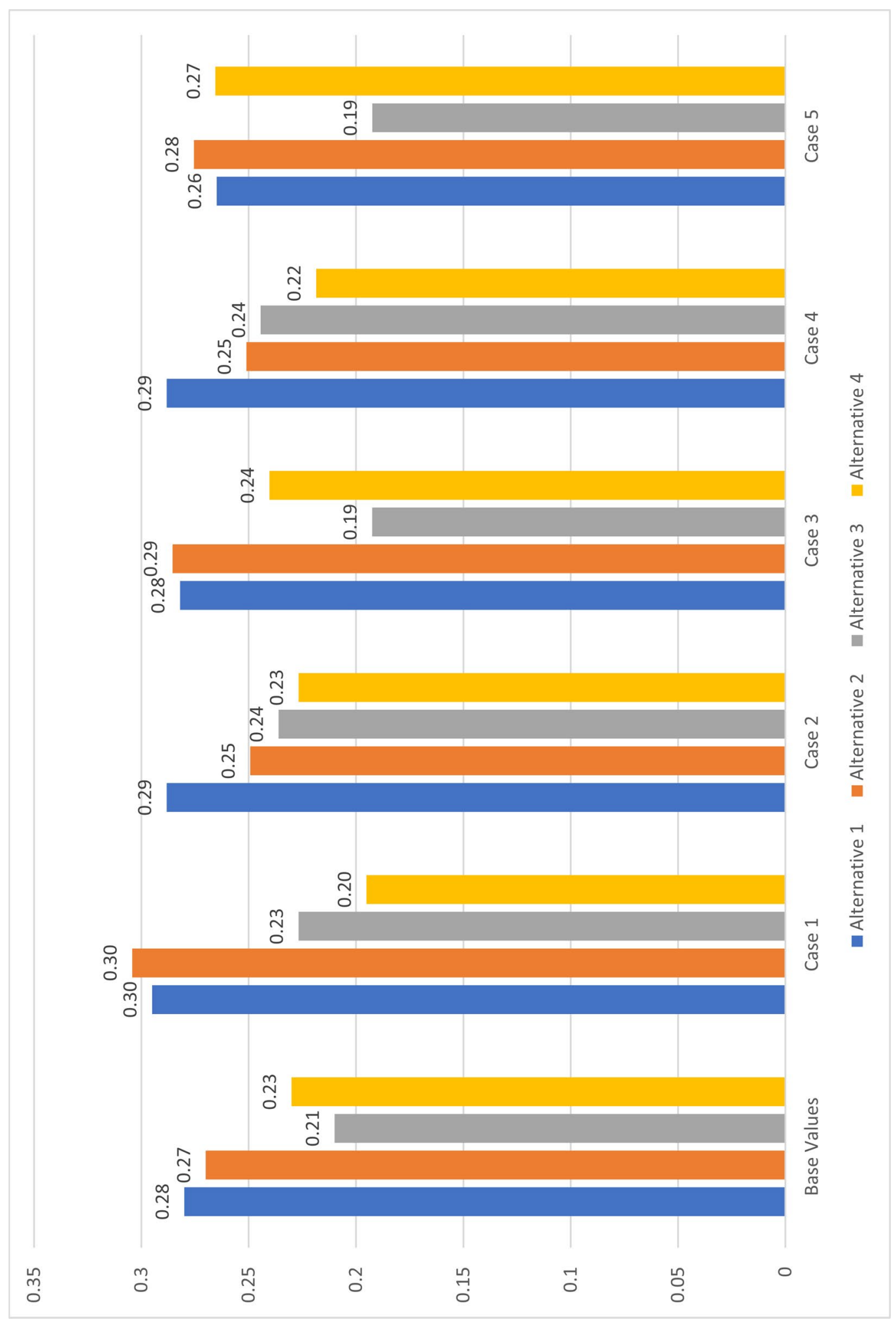

Figure 65: Summary of Case sensitive Analysis 
Table 84: Summary of Case sensitive Analysis - Weights

\begin{tabular}{|c|c|c|c|c|c|c|}
\hline Alternatives & Base Values & Case 1 & Case 2 & Case 3 & Case 4 & Case 5 \\
\hline $\begin{array}{c}\text { Alternative } \\
1\end{array}$ & 0.28 & 0.30 & 0.29 & 0.28 & 0.29 & 0.26 \\
\hline $\begin{array}{c}\text { Alternative } \\
2\end{array}$ & 0.27 & 0.30 & 0.25 & 0.29 & 0.25 & 0.28 \\
\hline $\begin{array}{c}\text { Alternative } \\
3\end{array}$ & 0.21 & 0.23 & 0.24 & 0.19 & 0.24 & 0.19 \\
\hline $\begin{array}{c}\text { Alternative } \\
4\end{array}$ & 0.23 & 0.20 & 0.23 & 0.24 & 0.22 & 0.27 \\
\hline
\end{tabular}

Table 85: Summary of Case sensitive Analysis - Ranks

\begin{tabular}{|c|c|c|c|c|c|c|}
\hline Alternatives & Base Values & Case 1 & Case 2 & Case 3 & Case 4 & Case 5 \\
\hline $\begin{array}{c}\text { Alternative } \\
1\end{array}$ & 1 & $1-2$ & 1 & 2 & 1 & $1-2$ \\
\hline $\begin{array}{c}\text { Alternative } \\
2\end{array}$ & 2 & $1-2$ & 2 & 1 & 2 & $1-2$ \\
\hline $\begin{array}{c}\text { Alternative } \\
3\end{array}$ & 4 & 3 & 3 & 4 & 3 & 3 \\
\hline $\begin{array}{c}\text { Alternative } \\
4\end{array}$ & 3 & 4 & 4 & 3 & 4 & 4 \\
\hline
\end{tabular}

It can be observed in Table 85 that significant changes in each criterion do not affect the order of the top-ranked alternatives. In the case of the lower-ranked alternatives, the order changed, except for the case of a dominant organizational criterion. Organizational aspects originally have a low weight related to other criteria; therefore, the low weight makes that any changes in the criteria values do not cause effects in the order of the alternatives. In the case of market criterion, which has the lowest weight compared to the other criteria, the changes to a dominant value only affect the lower alternatives' orders. The reasons for this can be attributed to the nature of technology of Alternatives 3 and 4, which are addressed to operational aspects. 
Due to the changes in the criteria to dominant values, the "alternative elasticity of criteria" can be obtained to see the percentual effect of changing the values of criteria on the relative values of each alternative.

The analysis is focused on criteria 1 and alternative 1 . The changes in values are related to based values " 0 " and the new values of criteria, sub-criteria, and alternatives.

A1: Relative value of Alternative 1 with respect to the mission

C: Relative value of criterion

S: Relative value of sub-criteria with respect to criteria

a: Relative value of alternatives with respect to sub-criteria

The relative value of A with respect to the mission is obtained from:

$\mathrm{A} 1=\mathrm{C}_{1}\left(\mathrm{~S}_{1} \mathrm{a}_{1}+\mathrm{S}_{2} \mathrm{a}_{4}+\mathrm{S}_{3} \mathrm{a}_{4}\right)+\mathrm{C}_{2}\left(\mathrm{~S}_{4} \mathrm{a}_{10}+\mathrm{S}_{5} \mathrm{a}_{13}\right)+\mathrm{C}_{3}\left(\mathrm{~S}_{6} \mathrm{a}_{16}+\mathrm{S}_{7} \mathrm{a}_{19}\right)$

$\mathrm{A} 1=\mathrm{c}_{1}\left(\mathrm{~S}_{1} \mathrm{a}_{1}+\mathrm{S}_{2} \mathrm{a}_{4}+\mathrm{S}_{3} \mathrm{a}_{4}\right)+\mathrm{c}_{2}\left(\mathrm{~S}_{4} \mathrm{a}_{10}+\mathrm{S}_{5} \mathrm{a}_{13}\right)+\mathrm{c}_{3}\left(\mathrm{~S}_{6} \mathrm{a}_{16}+\mathrm{S}_{7} \mathrm{a}_{19}\right)$

The alternative elasticity of criteria can be defined as:

$\frac{\delta A_{1} C_{1}}{\delta C_{1} A_{1}}=\frac{C_{1}\left(S_{1} a_{1}+S_{2} a_{4}+S_{3} a_{7}\right)}{A_{1}}=\frac{C_{1}\left(S_{1} a_{1}+S_{2} a_{4}+S_{3} a_{7}\right)}{C_{1}\left(S_{1} a_{1}+S_{2} a_{4}+S_{3} a_{7}\right)+C_{2}\left(S_{4} a_{10}+S_{5} a_{13}\right)+C_{3}\left(S_{6} a_{16}+S_{7} a_{19}\right)}$

If: $\propto_{1}=C_{1}\left(S_{1} a_{1}+S_{2} a_{4}+S_{3} a_{7}\right), \propto_{2}=C_{2}\left(S_{4} a_{10}+S_{5} a_{13}\right), \propto_{3}=C_{3}\left(S_{6} a_{16}+S_{7} a_{19}\right)$

Then: $\frac{\delta A_{1} C_{10}}{\delta C_{1} A_{10}}=\frac{1}{1+\frac{\alpha_{2}}{\alpha_{1}}+\frac{\alpha_{3}}{\alpha_{1}}}$

If $\mathrm{C}_{2}$ and $\mathrm{C}_{3}=0$, then $\mathrm{C}_{1}=1: \quad \frac{\delta A_{1} C_{1}}{\delta C_{1} A_{1}}=1$ 
If $\mathrm{C}_{2} \sim 1$, then $\mathrm{C}_{3}=0, \mathrm{C}_{1}=0: \quad \frac{\delta A_{1} C_{1}}{\delta C_{1} A_{1}}=0$

The analysis can be replicated in Figure 66:

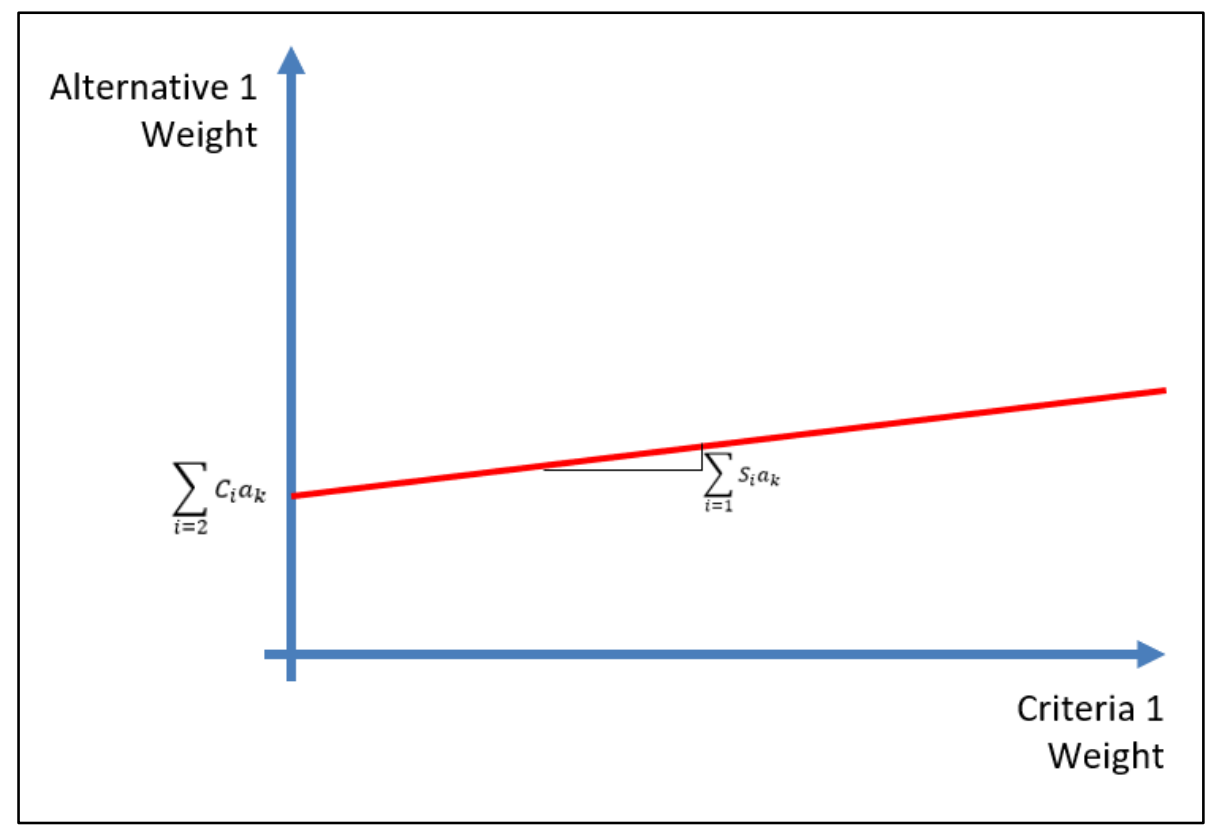

Figure 66: Alternative Elasticity of Criteria

In Figure 66, the line shows a low slope since changes in the values of alternative weights are not significant when the criteria weights changed, even to dominant values. In this case, the elasticity of the alternatives based on changes in criteria depends on the specific ratio of relative values of the Alternative 1 to the other relative values. Additionally, a perfect elastic effects exist when $\mathrm{C} 1$ is maximized and other criteria minimized are close to zero. A perfect inelastic effect exists when the Criteria 1 or relative values of alternative 1 are close to zero. In the specific case of the BPA model, the effects are close to a perfect inelastic effect. Therefore, changes in $\mathrm{C}$ will not have significant effects on A. In order to have a significant impact from changes in $\mathrm{C}$, the level of Alternative A needs to be high. 


\subsection{Post Hoc Model Results Evaluation}

After validating and quantifying the HDM model, a post hoc evaluation was done asking experts if the model and the final results (weights and values) were logical. Table 86 shows the positive results and comments from experts regarding to the model. For the 12 experts, the model elements and weights are logical and are in their expectations.

Table 86: Post Hoc Model Validation

\begin{tabular}{|c|c|c|c|}
\hline & Expert & Yes & No \\
\hline 1 & Expert 10 & X & \\
\hline 2 & Expert 24 & X & \\
\hline 3 & Expert 16 & X & \\
\hline 4 & Expert 2 & X & \\
\hline 5 & Expert 27 & X & \\
\hline 6 & Expert 5 & X & \\
\hline 7 & Expert 3 & X & \\
\hline 8 & Expert 11 & X & \\
\hline 9 & Expert 25 & X & \\
\hline 10 & Expert 19 & X & \\
\hline 11 & Expert 7 & Expert 1 & \\
\hline 12 & &
\end{tabular}




\section{CHAPTER 9: RESEARCH CONCLUSIONS}

\subsection{Conclusions and Contribution}

This research is focused on $R \& D$ project selection and evaluation in power transmission utilities that are under regulation. High levels of regulation affect the economy, entrepreneurship, and allocation of investments. In this context, the specific characteristics of regulated organizations influence the evaluation of R\&D investment projects. Consequently, R\&D project evaluations in regulated organizations imply different criteria and sub-criteria to align with the utility objectives and market conditions.

A holistic assessment of the criteria and sub-criteria regarding $R \& D$ project selection in regulated organizations was developed. The assessment becomes one of the contributions of this research for identifying the main criteria and sub-criteria linked to the $\mathrm{R} \& \mathrm{D}$ project selection in the electric transmission sector. The holistic approach the risk of investments in R\&D projects.

This research also developed a model for evaluating $R \& D$ projects in the electric transmission sector based on the multi-criteria analysis. Accordingly, this research followed a systematic approach for formulating and developing a multi-criteria model that allows identifying all the factors related to $R \& D$ projects and their respective evaluation. The systematic approach helped formulate the model, allowed to eliminate biases, and increased the effectiveness of evaluating the projects. The Hierarchical Decision Model (HDM) has been used to evaluate $R \& D$ projects from a multi-criteria analysis. The 
categories and factors associated with $\mathrm{R} \& \mathrm{D}$ projects in regulated organizations were divided into four levels: 1) Mission, 2) Criteria, 3) Sub-criteria, 4) Alternatives. Consequently, the HDM model of this thesis can be adopted not only in the power transmission utility sector, but in any organizations with similar characteristics by adjusting to particular characteristics and conditions.

The HDM model for selecting R\&D projects in the specific context of a regulated organization is a significant contribution. Based on the literature, the model incorporates all the elements and factors that affect R\&D projects aligning with the strategies of organizations. The HDM model incorporates all the theoretical elements related to R\&D project analysis, regulatory models, risk analysis, market analysis, and economic theories. The integration of factors from literature and theoretical aspects make the model robust and reliable. The theoretical aspect contributes to the generalization of the model in the context of geographical utilization across the states and/or nations, as well as different types of regulated organizations. Finally, the generalization and robustness of the model is a fruit of participation of unbiased panel experts who were selected based on their background, experience, types of organization, and location (the US. or overseas) with similar political and economic conditions.

Based on systematic steps, five criteria and 24 sub-criteria were identified and validated. For the practical application of the model, cases from BPA, a US electrical transmission utility, was used. BPA had 28 projects that were clustered in groups of four. The presented cases used one of these clusters, with four projects focused on the same objectives and characteristics. The results indicated that regulatory aspects play a crucial 
role in the R\&D project selection; the economic aspect is important for assessing how the R\&D project can contribute to value-added; and the changes in criteria weights levels do not affect the changes in the alternatives. These results suggest that in order to have considerable effects on the arrangement of alternatives by changing the weights of criteria, these weights of alternatives need to be significantly different. As well as the Technical Success, time to the market, and strategic fit as the sub-criteria with the highest weights, the regulations on maintaining high levels of reliability are important.

\subsection{Limitations of the Research}

The research is focused on the important aspect of selecting and evaluating R\&D projects in the power transmission utilities. However, there are some limitations to the model that need to be mentioned. First, the model provides the rank of projects according to the importance and weights obtained from experts. This model will not provide or determine if the project is feasible considering all the aspects. However, the model can be considered a complement of other evaluation tools such as NPV or C/B ratio.

The HDM is based on Subject-Matter Experts (SMEs) judgments. Therefore, the judgments are subjective and depend on experts' knowledge. There might be some limited knowledge and biases from experts that affect the validation and results of the model; however, following the adequate methodologies for selecting and forming panels can minimize this problem.

The priorities and relative weights of the criteria and sub-criteria may not be the same for other organizations similar to BPA. The results or outputs of the HDM model can be the 
same for many of these organizations, but can be changed for others, depending on the specific objective of the organizations and the use of different SMEs.

Additionally, the relative values are taken during a specific point of time. The values of quantification of the model may vary according to the circumstances, the new drivers, and the objective of the power transmission organizations in a certain time.

From the interviews to SMEs, the validation of the model depends on subjective perspectives. It is important to identify the experts who are highly related and knowledgeable about the high-level strategies of the organization.

The model is built during a specific point in time. Since R\&D projects in the area of power transmission are considered long term projects, the structure of the model is susceptible to change. These changes are already mentioned as the main factors affecting these types of investments such as political, technical, economic, organizational, etc. These types of organizations are sensitive to changes in political, market, and social aspects.

\subsection{Future Work}

This research has provided an assessment of the criteria and sub-criteria that influence the decisions of evaluating $R \& D$ projects in utilities under regulation. The model was built based on a systematic analysis of the literature, which includes journal papers, papers analyzing projects, as well as the important inclusion of theoretical aspects. Since the model is focused on transmission utilities, the adjustment of the model to different characteristics is a potential research area to be done. The model provides a quantitative analysis for alternatives based on a specific utility; therefore, adapting the model to other 
scenarios and conditions is important and will represent an important step to generalize the model.

Another future research opportunity is to analyze the model and contrast the results at different periods of time. The dynamic changes in the conditions and characteristics will provide valuable information about the adjustment of R\&D projects to a different circumstance. As part of this analysis, the stability of the results will be evaluated and provide projects and strategies of utilities are in the same direction. 


\section{REFERENCES}

[1] D. F. Kocaoglu, "A participative approach to program evaluation," IEEE Transactions on Engineering Management, vol. EM-30, no. 3, pp. 112-118, 1983.

[2] K. Costello, "Research and development by public utilities: Should be done?," National Regulatory Research Institute, Seattle, WA, USA, 2015.

[3] C. Yi, Y. Ning, and Q. Jin, "A fuzzy multi-criteria evaluation approach for R\&D project selection," in 4th International Conference on Wireless Communications, Networking and Mobile Computing. IEEE, 2008, pp. 1-4.

[4] J. Lee and S. Lee, "R\&D project selection: Behavior and practice in a newly industrializing country," IEEE Transactions on Engineering Management, vol. EM33, no. 3, pp. 141-147, Aug. 1986.

[5] M. Habib, R. Khan, and J. L. Piracha, "Analytic Network Process applied to R\&D project selection," in 2009 International Conference on Information and Communication Technologies, vol. 0786. pp. 1-19, 2009.

[6] M. J. Liberatore, "An expert support system for R\&D project selection," Mathematical and Computer Modelling, vol. 11, pp. 260-265, 1988.

[7] Q. Tian, J. Ma, J. Liang, R. C. W. Kwok, and O. Liu, "An organizational decision support system for effective R\&D project selection," Decision Support Systems, vol. 39, no. 3, pp. 403-413, May 2005.

[8] J. L. Ringuest, S. B. Graves, and R. H. Case, "Mean-Gini analysis in R\&D portfolio selection," European Journal of Operational Research, vol. 154, no. 1, pp. 157169, Apr. 2004.

[9] A. Bin, A. Azevedo, L. Duarte, S. Salles-Filho, and P. Massaguer, "R\&D and innovation project selection: Can optimization methods be adequate?," Procedia Computer Science, vol. 55, pp. 613-621, 2015.

[10] S. Hashemkhani Zolfani, J. Salimi, R. Maknoon, and S. Kildienè, "Technology Foresight about R\&D projects selection: Application of SWARA method at the policy making level," Engineering Economics, vol. 26, no. 5, Dec. 2015.

[11] F. Hassanzadeh, M. Collan, and M. Modarres, "A technical note on 'A fuzzy set approach for R\&D portfolio selection using a real options valuation model' by Wang and Hwang (2007)," Omega, vol. 39, no. 4, pp. 464-465, Aug. 2011.

[12] M. Ashrafi, H. Davoudpour, and M. Abbassi, "Developing a decision support system for R\&D project portfolio selection with interdependencies," AIP Conference Proceedings, vol. 1499, no. 1, pp. 370-378, Nov. 2012.

[13] C. Carlsson, R. Fullér, M. Heikkilä, and P. Majlender, "A fuzzy approach to R\&D project portfolio selection," International Journal of Approximate Reasoning, vol. 44, no. 2, pp. 93-105, Feb. 2007. 
[14] C. P. Lawson, P. J. Longhurst, and P. C. Ivey, "The application of a new research and development project selection model in SMEs," Technovation, vol. 26, no. 2, pp. 242-250, Feb. 2006.

[15] M. A. Brown, "Market failures and barriers as a basis for clean energy policies," Energy Policy, vol. 29, no. 14, pp. 1197-1207, Nov. 2001.

[16] P. Sanyal and L. R. Cohen, "Powering progress: Restructuring, competition, and R\&D in the US electric utility industry," The Energy Journal, pp. 41-79, 2009.

[17] A. Purnus and C.-N. Bodea, "Project prioritization and portfolio performance measurement in project oriented organizations," Procedia - Social and Behavioral Sciences, vol. 119, pp. 339-348, 2014.

[18] P. McLaughlin and O. Sherouse, "The McLaughlin-Sherouse list: The 10 mostregulated industries of 2014 | Mercatus Center," 2016. [Online]. Available: https://www.mercatus.org/publications/regulation/mclaughlin-sherouse-list-10most-regulated-industries-2014. [Accessed: 06-Aug-2020].

[19] Changsheng Yi, "A decision-making approach for R\&D project selection in a fuzzy environment," in in International Seminar on Business and Information Management, 2008, pp. 372-375.

[20] R. Bhattacharyya, P. Kumar, and S. Kar, "Fuzzy R\&D portfolio selection of interdependent projects," Computers \& Mathematics with Applications, vol. 62, no. 10, pp. 3857-3870, Nov. 2011.

[21] L. M. Meade and A. Presley, "R\&D project selection using the Analytic Network Process," IEEE Transactions on Engineering Management, vol. 49, no. 1, pp. 5966, 2002.

[22] F. Hassanzadeh, M. Collan, and M. Modarres, "A practical approach to R\&D portfolio selection using the fuzzy pay-off method," IEEE Transactions on Fuzzy Systems, vol. 20, no. 4, pp. 615-622, Aug. 2012.

[23] W. Jingmei and G. Peng, "The robustness risk and selection optimization of R\&D project portfolio under uncertainty," in 2015 IEEE International Conference on Grey Systems and Intelligent Services (GSIS), 2015, pp. 622-627.

[24] N. M. Arratia M., F. López I., S. E. Schaeffer, and L. Cruz-Reyes, "Static R\&D project portfolio selection in public organizations," Decision Support Systems, vol. 84, pp. 53-63, Apr. 2016.

[25] D. Leonard-Barton and W. A. Kraus, "Implementing new technology," Harvard Business Review, Nov-1985.

[26] K. Lauritzen, "Method for optimal capability-based R\&D portfolio selection," in 2014 IEEE International Technology Management Conference, 2014, pp. 1-4.

[27] C.-C. Huang, P.-Y. Chu, and Y.-H. Chiang, "A fuzzy AHP application in government-sponsored R\&D project selection," Omega, vol. 36, no. 6, pp. 1038- 
1052, Dec. 2008.

[28] K. Costello, "R\&D and public utilities," Electricity Journal, vol. 29, no. 5, pp. 19 26, 2016.

[29] J. Behrens, "A lack of insight: An experimental analysis of R\&D managers' decision making in innovation portfolio management," Creativity and Innovation Management, vol. 25, no. 2, pp. 239-250, Jun. 2016.

[30] M. J. Liberatore, "An extension of the analytic hierarchy process for industrial R\&D project selection and resource allocation," IEEE Transactions on Engineering Management, no. 1, pp. 12-18, 1987.

[31] A. Roos, "R\&D project portfolio selection in new product developing organizations," Fraunhofer Insrtitut Arbeitswirtschaft und Organisation, 2008.

[32] M. Ghobakhloo, T. S. Hong, M. S. Sabouri, and N. Zulkifli, "Strategies for successful information technology adoption in small and medium-sized enterprises," Information, vol. 3, no. 4, pp. 36-67, Feb. 2012.

[33] C. Gaspoz and Y. Pigneur, "Preparing a negotiated R\&D portfolio with a prediction market," in Proceedings of the Annual Hawaii International Conference on System Sciences, 2008, pp. 1-10.

[34] R. G. Cooper and E. J. Edgett, Scott J \& Kleinschmidt, "Portfolio management for new product development: Results of an industry practices study," $R \& D$ Management (Industrial Research Institute, Inc.), vol. 13, no. 4, pp. 1-39, 2001.

[35] C.-T. Chen and W.-Z. Hung, "Applying fuzzy linguistic variable and ELECTRE method in R\&D project evaluation and selection," in 2008 IEEE International Conference on Industrial Engineering and Engineering Management, 2008, pp. 999-1003.

[36] A. Jekunen, "Decision-making in product portfolios of pharmaceutical research and development - managing streams of innovation in highly regulated markets," Drug Design, Development and Therapy, p. 2009, Oct. 2014.

[37] F. Nagm and K. Kautz, "It doesn't add up: Why financial evaluation methods are inadequate in appraising IS investments," Australasian Conference on Information Systems, pp. 141-151, 2007.

[38] M. J. Liberatore and G. J. Titus, "The practice of Management Science in R\&D Project Management," Management Science. Aug1983, vol. 29, no. 8, pp. 962-974, 1983.

[39] A. Amaro, J. Cunha, E. Ares, and M. Araújo, "Assessment of companies practices concerning the evaluation of $\mathrm{R} \& \mathrm{D}$ investment project," in 2 th International Conference on Technology Policy and Innovation, 2009, pp. 1-12.

[40] T. Conka and S. Ercan, "The combined decision model for selecting and prioritizing research and development projects," in Proceedings of 2nd International 
Conference on Recent Advances in Space Technologies, 2005, pp. 823-828.

[41] G. F. Nemet and D. M. Kammen, "U.S. energy research and development: Declining investment, increasing need, and the feasibility of expansion," Energy Policy, vol. 35, no. 1, pp. 746-755, Jan. 2007.

[42] A. Sterlacchini, "Energy R\&D in private and state-owned utilities: An analysis of the major world electric companies," Energy Policy, vol. 41, no. November, pp. 494-506, 2012.

[43] F. Zubascu and S. Business, "European power suppliers boost R\&D investment," 2016. [Online]. Available: http://sciencebusiness.net/news/77392/European-powersuppliers-boost-R-and-D-investment. [Accessed: 11-May-2016].

[44] U.S. DOE Energy Information Administration, "Direct federal financial interventions and subsidies in energy in fiscal year 2010," Energy Information Administration, no. March, 2015.

[45] B. R. Fonslow et al., "NIH Public Access," Adm Policy Ment Health, vol. 10, no. 1, pp. 54-56, 2013.

[46] K. W. Cheung, G. W. Rosenwald, X. Wang, and D. I. Sun, "Restructured electric power systems and electricity markets," in Restructured Electric Power Systems, X.-P. Zhang, Ed. John Wiley \& Sons, Inc., 2010, pp. 53-97.

[47] M. T. Booher, D. F. Proaño, and K. Kash, "PLC - Electricity regulation in the United States: overview," Practical Law, 13-Mar-2016. [Online]. Available: http://us.practicallaw.com/8-525-5799?source=relatedcontent\#a1003615.

[48] E. E. Sauma and S. S. Oren, "Proactive planning and valuation of transmission investments in restructured electricity markets," Journal of Regulatory Economics, vol. 30, no. 3, pp. 358-387, Apr. 2006.

[49] G. Gross, "The evolution of the USA open access transmission regime," in University of Illinois at Urbana-Champaign, ICPSOP, 2000.

[50] W. J. Hausman and J. L. Neufeld, "How politics, economics, and institutions shaped electric utility regulation in the United States: 1879-2009," Business History, vol. 53, no. 5, pp. 723-746, Mar. 2011.

[51] U.S. Departament of Energy, "United States electricity industry primer," 2015.

[52] America's Power Plan, "Ratemaking and utility business models," America's Power Plan, 13-Mar-2017. [Online]. Available: http://americaspowerplan.com/powertransformation-solutions/ratemaking-and-utility-business-models/.

[53] S. Borenstein and J. Bushnell, "The US electricity industry after 20 years of restructuring," Annu. Rev. Econ., vol. 7, no. 1, pp. 437-463, Mar. 2015.

[54] J. Lazar, Electricity Regulation in the US: A Guide, Second. 2016.

[55] M. Warwick, "A primer on electric utilities, deregulation, and restructuring of U.S. 
electricity markets," Richland, Washington, Mar. 2002.

[56] Stinson Leonard Street, "FERC ELECTRICITY 101." Washington, DC, 13-Mar2014.

[57] PrivacySense.net, "The Difference Between the Private and Public Sector," PrivacySense.net, 13-Mar-2015. [Online]. Available: http://www.privacysense.net/difference-between-private-public-sector/. [Accessed: 26-May-2020].

[58] Public Power Council, Public Power Chronicle - A Guide to Public Power in the Pacific Northwest for the 21st Century. Portland OR: Public Power Council, 2002.

[59] California Energy Commision, "Differences between publicly and investor-owned Utilities," California Energy Commission, 15-Apr-2017. [Online]. Available: http://www.energy.ca.gov/pou_reporting/background/difference_pou_iou.html. [Accessed: 26-May-2020].

[60] R. C. Agarwal, "Public utilities: Meaning, characteristics, forms, privileges and obligations," YourArticleLibrary.com: The Next Generation Library. 13-Mar-2014.

[61] P. Illingworth and W. E. Parmet, "Health as a global public good," in Health of Newcomers, 2013, no. November.

[62] J. Pfeifenberger, J. Chang, M. Davis, and M. Geronimo, "Competition in transmission planning and development: Current status and international experience," Washington DC, 2014.

[63] RAP Energy Solutions for Changing World, "Electricity regulation in the US: A guide," Montpelier, Vermont, 2011.

[64] J. Tarbert, "Public power's business model: A primer." Public Power and the American Public Power Association, 2012.

[65] M. H. Brown and R. P. Sedano, Electricity transmission: A primer. Denver, Colorado: National Council on Electric[ity] Policy, 2004.

[66] J. J. Hoecker and D. W. Smith, "Regulatory federalism and development of electric transmission: A brewing Storm," Energy Law Journal, vol. 35, p. 71, Mar. 2014.

[67] M. Sowinski, "Practical, legal, and economic barriers to optimization in energy transmission and distribution," Journal of Land Use \& Environmental Law, vol. 26, no. 2, pp. 503-530, Mar. 2011.

[68] S. Cicala et al., "Imperfect markets versus imperfect regulation in U.S. electricity generation," 2017.

[69] D. P. Tuttle et al., "The history and evolution of the U.S. electricity industry," University of Texas - Energy Institute, Austin, TX, Apr. 2016.

[70] Utility Dive and PA Consulting, "State of the electric utility survey," 2017. 
[71] R. Lehr, "New utility business models: Utility and regulatory models for the modern era." 02-Apr-2013.

[72] L. Kiesling, "Rethink the natural monopoly justification of electricity regulation," Reason Foundation. 14-Mar-2017.

[73] Edison ElectricInstitute, "Key facts about electric power industry," EEI Edison Electric Institute. Washington, D.C, USA, 13-Mar-2017.

[74] T. U. Daim, T. Oliver, and I. Iskin, "Research and development (R\&amp;D) portfolio management in the electric utility sector: Does it change for the service sector?," Benchmarking: An International Journal, vol. 20, no. 2, pp. 186-211, Apr. 2013.

[75] T. Jamasb and M. Pollitt, "Liberalisation and R\&D in network industries: The case of the electricity industry," Research Policy, vol. 37, no. 6-7, pp. 995-1008, Mar. 2008.

[76] S. Schmitt and K. Denes, "The impact of the regulatory reform process on R\&D investment of european electricity utilities," in Beiträge zur Jahrestagung des Vereins für Socialpolitik, 2013.

[77] H. Davoudpour, S. Rezaee, and M. Ashrafi, "Developing a framework for renewable technology portfolio selection: A case study at a R\&D center," Renewable and Sustainable Energy Reviews, vol. 16, no. 6, pp. 4291-4297, Aug. 2012.

[78] S. K. Lee, G. Mogi, and K. S. Hui, “A fuzzy analytic hierarchy process (AHP)/data envelopment analysis (DEA) hybrid model for efficiently allocating energy R\&D resources: In the case of energy technologies against high oil prices," Renewable and Sustainable Energy Reviews, vol. 21, pp. 347-355, May 2013.

[79] L. M. Meade and A. Presley, "R\&D project selection using the analytic network process," IEEE transactions on engineering management, vol. 49, no. 1, pp. 59-66, 2002.

[80] S. K. Lee, G. Mogi, M. Koike, K. S. Hui, and J. W. Kim, "Fuzzy integrated analytic hierarchy process approach for selecting strategic big-sized R\&D programs in the sector of energy technology development," in 2009 IEEE International Conference on Fuzzy Systems, Jeju Island, Korea, 2009, pp. 1432-1438.

[81] A. Ç. Tolga, "Fuzzy multicriteria R\&D project selection with a real options valuation model," Journal of Intelligent \& Fuzzy Systems, vol. 19, no. 4, 5, pp. 359371, 2008.

[82] Y.-G. Hsu, G.-H. Tzeng, and J. Z. Shyu, "Fuzzy multiple criteria selection of government-sponsored frontier technology R\&D projects," R\&D Management, vol. 33, no. 5, pp. 539-551, 2003.

[83] M. Hudymáčová, M. Benková, J. Pócsová, and T. Škovránek, "Supplier selection based on multi-criterial AHP method," Acta Montanistica Slovaca Ročník, vol. 15, 
no. 3, pp. 249-255, 2010.

[84] C. J. M. Victório, H. G. Costa, and C. G. de Souza, "Modeling selection criteria of R\&D projects for awarding direct subsidies to the private sector," Science and Public Policy, vol. 43, no. 2, pp. 275-287, Apr. 2016.

[85] P. Guo, J. J. Liang, Y. M. Zhu, and J. F. Hu, "R\&D project portfolio selection model analysis within project interdependencies context," in 2008 IEEE International Conference on Industrial Engineering and Engineering Management, 2008, pp. 994-998.

[86] Q. Tian, J. Ma, and O. Liu, "A hybrid knowledge and model system for R\&D project selection," Expert systems with applications, vol. 23, no. 3, pp. 265-271, 2002.

[87] J. Wang and W.-L. Hwang, "A fuzzy set approach for R\&D portfolio selection using a real options valuation model," Omega, vol. 35, no. 3, pp. 247-257, Jun. 2007.

[88] H. Akers, "Advantages \& disadvantages of Net Present Value in project selection | Chron.com." [Online]. Available: http://smallbusiness.chron.com/advantagesdisadvantages-net-present-value-project-selection-54753.html. [Accessed: 22-May2017].

[89] I. Iskin, "An assessment model for energy efficiency program planning in electric utilities: Case of the Pacific of Northwest U.S.A.," Engineering and Technology Management, Portland State University, Oregon, USA, 2014.

[90] I. S. Litvinchev, F. Lopez, A. Alvarez, and E. Fernandez, "Large-scale public R\&D portfolio selection by maximizing a biobjective impact measure," IEEE Transactions on Systems, Man, and Cybernetics - Part A: Systems and Humans, vol. 40, no. 3, pp. 572-582, May 2010.

[91] R. P. Mohanty, R. Agarwal, A. K. Choudhury, and M. K. Tiwari, "A fuzzy ANPbased approach to R\&D project selection: A case study," International Journal of Production Research, vol. 43, no. 24, pp. 5199-5216, Dec. 2005.

[92] M. Oral, O. Kettani, and P. Lang, "A methodology for collective evaluation and selection of industrial R\&D projects," Management Science, vol. 37, no. 7, pp. 871$885,1991$.

[93] Y. H. Chun, "Sequential decisions under uncertainty in the R\&D project selection problem," IEEE Transactions on Engineering Management, vol. 41, no. 4, pp. 404413, 1994.

[94] Z. Danmei, Z. Tie, W. Xingtong, and C. Dongling, "A novel R\&D project portfolio selection decision approach based on fuzzy logic and heuristics scheduling," 2008, pp. 144-147.

[95] J. D. Linton, S. T. Walsh, and J. Morabito, "Analysis, ranking and selection of R\&D projects in a portfolio," $R \& D$ Management, vol. 32, no. 2, pp. 139-148, Mar. 2002.

[96] R. L. Schmidt, "A model for R\&D project selection with combined benefit, outcome 
and resource interactions," IEEE Transactions on Engineering Management, vol. 40, no. 4, pp. 403-410, 1993.

[97] E. Fernandez, F. Lopez, J. Navarro, I. Vega, and I. Litvinchev, "An integrated mathematical-computer approach for R\&D Project selection in large public organisations," International Journal of Mathematics in Operational Research, vol. 1, no. 3, pp. 372-396, 2009.

[98] I. S. Litvinchev, F. López, A. Alvarez, and E. Fernández, "Large-scale public RD portfolio selection by maximizing a biobjective impact measure," IEEE Transactions on Systems, Man, and Cybernetics Part A:Systems and Humans, vol. 40, no. 3, pp. 572-582, 2010.

[99] N. Maribel, A. Martínez, and F. López, "MILP for selecting portfolio of R \& D projects in public organizations with partial and full resource allocation policies," in Fourth International Workshop on Knowledge Discovery, Knowledge Management and Decision Support, pp. 241-246, 2013.

[100] P. L. Pereira and F. M. Veloso, "RD activity selection process: Building a strategyaligned RD portfolio for government and nonprofit organizations," IEEE Transactions on Engineering Management, vol. 56, no. 1, pp. 95-105, 2009.

[101] R. Gasparini et al., "How can the results of Health Technology Assessment (HTA) evaluations applied to vaccinations be communicated to decision-makers and stakeholders? The ISPOR Rome chapter project," Journal of Preventive Medicine and Hygiene, vol. 56, no. 4, pp. E150-E154, 2015.

[102] M. Besombes, Y. Goth, and X. Carniel, "Psycho acoustic characterisation of lawnmowers versus standard a-weighted sound power and comparison with virtual prototyping results," in 13th International Congress on Sound and Vibration 2006, ICSV, 2006, vol. 3, pp. 2469-2476.

[103] A. J. Brunett, D. Grabaskas, M. Bucknor, and S. Passerini, "A methodology for the integration of passive system reliability with success criteria in a probabilistic framework for advanced reactors," American Society of Mechanical Engineers (ASME), Argonne, IL, US., 2016.

[104] M. Conte, "ENEA's energy storage activities in the Italian electric system research project," Institute of Electrical and Electronics Engineers Inc., Tech. Unit "Advanced Technologies for Energy and Industry" - Coordination of Energy Storage Systems, ENEA - Italian National Agency for New Technologies, Energy and Sustainable Economic Development, Rome, Italy, 2015.

[105] D. Cornic, "Efficient recovery of braking energy through a reversible dc substation," in International Conference on Electrical Systems for Aircraft, Railway and Ship Propulsion, ESARS 2010, 2010.

[106] T. U. Daim and T. Oliver, "Implementing technology roadmap process in the energy services sector: A case study of a government agency," Technological Forecasting and Social Change, vol. 75, no. 5, pp. 687-720, 2008. 
[107] D. Grabaskas, A. J. Brunett, and M. Bucknor, "A methodology for the integration of a mechanistic source term analysis in a probabilistic framework for advanced reactors," in 2016 24th International Conference on Nuclear Engineering, ICONE 2016, 2016, vol. 2.

[108] D. Grabaskas, A. J. Brunett, and M. Bucknor, "A methodology for the development of a reliability database for an advanced reactor probabilistic risk assessment," in 2016 24th International Conference on Nuclear Engineering, ICONE 2016, 2016, vol. 2.

[109] Y. Huang, D. Liu, and H. Liao, "Site and size selection strategies of energy storage system based on power supply and storage capability index," in International Conference on Renewable Power Generation, RPG 2015, 2015, vol. 2015, no. CP679.

[110] L. A. Johnson and D. N. Schochet, "Applying proven Organic Rankine cycle technology for the generation of electricity from geothermal water produced by oil and gas wells," in Geothermal Resources Council - Annual Meeting of the Geothermal Resources Council 2007 "Renewable Baseload Energy: Geothermal Heat Pumps to Engineered Reservoirs,” 2007, vol. 31, pp. 601-603.

[111] F. Leménager et al., "Assessment and outlook of the opennode smart grid architecture," in 22nd International Conference and Exhibition on Electricity Distribution, CIRED 2013, 2013, vol. 2013, no. 615 CP.

[112] C. Sabelli et al., "Advanced operation of the high voltage system highlights from the italian plan for system security," in CIGRE 2011 Bologna Symposium - The Electric Power System of the Future: Integrating Supergrids and Microgrids, 2011.

[113] T. Sakai et al., "Activities of the safety and operation project for the international research and development of the sodium-cooled fast reactor in the generation IV international forum," in 2016 24th International Conference on Nuclear Engineering, ICONE 2016, 2016, vol. 2.

[114] L. Sigrist, K. May, A. Morch, P. Verboven, P. Vingerhoets, and L. Rouco, "On scalability and replicability of smart grid projects-A case study," Energies, vol. 9, no. 3, 2016.

[115] A. J. C. Trappey, C. V Trappey, U. H. Govindarajan, J. J. Sun, and A. C. Chuang, "A Review of Technology Standards and Patent Portfolios for Enabling CyberPhysical Systems in Advanced Manufacturing," IEEE Access, vol. 4, pp. 7356$7382,2016$.

[116] N. Wang and G. Mogi, "From Regulation to Deregulation: An Empirical Study of Japanese Electric Utility R\&D Investment Behavior under Transition," in 8th International Conference on Applied Energy, ICAE 2016, 2017, vol. 105, pp. 31933200.

[117] K.-L. Chang, "A Hybrid program projects selection model for nonprofit TV stations," Mathematical Problems in Engineering, vol. 2015, 2015. 
[118] D. W. Compton, R. Glover-Kudon, M. E. Avery, and C. L. Morris, "The collaborative evaluation fellows project: Background and overview of the model," Cancer Practice, vol. 9, no. SUPPL. 1, pp. S4-S10, 2001.

[119] N. Dehouche, "Non-profit project portfolio evaluation and selection: A multicriteria approach," International Journal of Applied Management Science, vol. 7, no. 4, pp. 338-363, 2015.

[120] J. Johnson and C. Marshall, "Convergent usability evaluation: A case study from the eirs project," in Conference on Human Factors in Computing Systems, CHI EA 2005, 2005, pp. 1501-1504.

[121] K. Joyner and R. J. Mash, "The value of intervening for intimate partner violence in South African primary care: Project evaluation," BMJ Open, vol. 1, no. 2, 2011.

[122] M. Lopez, "Faith matters: Developing the our whole lives evaluation and promotion project," American Journal of Sexuality Education, vol. 6, no. 1, pp. 13-19, 2011.

[123] R. Mott, K. Keller, and K. Funkenbusch, "Keep me doing what I love': A photovoice evaluation of the Missouri AgrAbility Project," Journal of Agromedicine, vol. 22, no. 4, pp. 425-431, 2017.

[124] M. Nagao, K. Kuji-Shikatani, and A. J. Love, "Preparing school evaluators: Hiroshima pilot test of the Japan evaluation society's accreditation project," Canadian Journal of Program Evaluation, vol. 20, no. 2, pp. 125-155, 2005.

[125] R. Rodriguez-García, D. Wilson, N. York, C. Low, N. N’Jie, and R. Bonnel, "Evaluation of the community response to HIV and AIDS: Learning from a portfolio approach," AIDS Care - Psychological and Socio-Medical Aspects of AIDS/HIV, vol. 25, no. SUPPL.1, pp. S7-S19, 2013.

[126] S. Y. Sohn, Y. Gyu Joo, and H. Kyu Han, "Structural equation model for the evaluation of national funding on R\&D project of SMEs in consideration with MBNQA criteria," Evaluation and Program Planning, vol. 30, no. 1, pp. 10-20, 2007.

[127] M. Viswanathan et al., "Cross-site evaluation of a comprehensive pediatric asthma project: The Merck Childhood Asthma Network, Inc. (MCAN).," Health promotion practice, vol. 12, no. 6 Suppl 1, pp. 20S-33S, 2011.

[128] B. Wang, K. Narvekar, and T. Nguyen, "The hierarchical decision model for nonprofit organization's project selection," in 2013 Portland International Conference on Management of Engineering and Technology, PICMET 2013, 2013, pp. 401410.

[129] M. N. M. Arratia, I. F. López, S. E. Schaeffer, and L. Cruz-Reyes, "Static R\&D project portfolio selection in public organizations," Decision Support Systems, vol. 84, pp. 53-63, 2016.

[130] W. Bronsgeest, R. Arendsen, and J. van Dijk, "Towards participatory e- 
government?: Learning from e-government project evaluations," in 9th IFIP WG 8.5 International Conference on Electronic Participation, ePart 2017, 2017, vol. 10429 LNCS, pp. 127-139.

[131] E. H. S. Cabral, "Values and public space: Frameworks and tools for evaluation of social projects," Revista de Administracao Publica, vol. 45, no. 6, pp. 1915-1941, 2011.

[132] M. Çağlar and S. Gürel, "Public R\&D project portfolio selection problem with cancellations," OR Spectrum, vol. 39, no. 3, pp. 659-687, 2017.

[133] M. García-Melón, R. Poveda-Bautista, and J. L. Del Valle M., "Using the strategic relative alignment index for the selection of portfolio projects application to a public Venezuelan Power Corporation," International Journal of Production Economics, vol. 170, pp. 54-66, 2015.

[134] I. Litvinchev, F. López, H. J. Escalante, and M. Mata, "A milp bi-objective model for static portfolio selection of R\&D projects with synergies," Journal of Computer and Systems Sciences International, vol. 50, no. 6, pp. 942-952, 2011.

[135] B. Mahdia and B. Hossein, "Project selection with outsourcing view using fuzzy TOPSIS linear assignment programming," in 4th IEEE International Conference on Management of Innovation and Technology, ICMIT, 2008, pp. 327-332.

[136] M. A. Ortíz, H. A. Felizzola, and S. N. Isaza, "A contrast between DEMATEL-ANP and ANP methods for six sigma project selection: A case study in healthcare industry," BMC Medical Informatics and Decision Making, vol. 15, no. 3, 2015.

[137] A. A. Ramaiah and N. C. Gawde, "Economic evaluation of a public-private mix TB Project in Tamil Nadu, India," Journal of Health Management, vol. 17, no. 3, pp. 370-380, 2015.

[138] S. Shenbaga Ezhil, "Integer programmig model in project selection and prediction using artificial neural network (ANN)," International Journal of Applied Engineering Research, vol. 10, no. 2, pp. 2541-2561, 2015.

[139] N. Wisitpongphan and T. Khampachua, "IT project prioritization and scoring system for thai public sectors," in Proceedings of the European Conference on eGovernment, ECEG, 2015, vol. 2015-Janua, pp. 300-307.

[140] D. Yakovlev, E. Yushkov, A. Pryakhin, and M. Bogatyreova, "Effectiveness evaluation of the R\&D projects in organizations financed by the budget expenses," International Conference for Young Scientists, Specialists, and Postgraduates on Nuclear Reactor Physics 2016, ICNRP 2016, vol. 781, no. 1, 2017.

[141] A. Kassem, K. Al-Haddad, D. Komljenovic, and A. Schiffauerova, "A value tree for identification of evaluation criteria for solar thermal power technologies in developing countries," Sustainable Energy Technologies and Assessments, vol. 16, pp. 18-32, 2016. 
[142] X. Li, X. Zhu, Q. Liao, and H. Sun, "Evaluation of power transmission and transformation projects using fuzzy multi-layer models," International Journal of Simulation: Systems, Science and Technology, vol. 17, no. 47, pp. 21.1-21.6, 2016.

[143] I. Matsukawa, "The effects of priority service on electricity transmission: The case of interconnection investment," in Transmission Lines: Theory, Types and Applications, Faculty of Economics, Musashi University, Tokyo, Japan: Nova Science Publishers, Inc., 2011, pp. 165-184.

[144] K. Takakura, S. Tanaka, T. Nakamura, K. Chatani, and Y. Kaji, "IASCC evaluation method for irradiated core internal structures in BWR power plants," in ASME 2010 Pressure Vessels and Piping Division/K-PVP Conference, PVP2010, 2010, vol. 6, pp. 675-684.

[145] Y. Yi, Z. Chen, and L. Wang, "Statistical evaluation and prediction of audible noise of HVDC transmission lines," in 2016 IEEE Conference on Electrical Insulation and Dielectric Phenomena, CEIDP 2016, 2016, vol. 2016-Decem, pp. 279-282.

[146] N. V Batalova, V. Maroussov, and F. G. Viens, "Selection of an optimal portfolio with stochastic volatility and discrete observations," in 2nd International Conference on Computational Finance and its Applications, COMPUTATIONAL FINANCE 2006, CF06, 2006, vol. 43, pp. 371-380.

[147] S. Brendle, "Portfolio selection under incomplete information," Stochastic Processes and their Applications, vol. 116, no. 5, pp. 701-723, 2006.

[148] E. Çanakoğlu and S. Özekici, "Portfolio selection in stochastic markets with HARA utility functions," European Journal of Operational Research, vol. 201, no. 2, pp. 520-536, 2010.

[149] H. Chang, "Dynamic portfolio selection with liability and stochastic interest rates in the utility framework," International Journal of Industrial and Systems Engineering, vol. 19, no. 2, pp. 169-189, 2015.

[150] H. Chang, K. Chang, and J.-M. Lu, "Portfolio selection with liability and affine interest rate in the HARA utility framework," Abstract and Applied Analysis, vol. 2014, 2014.

[151] Y. Cui, Y. Yu, and Z. Yang, "Application Effect evaluation of demonstration project of thyristor-controlled phase shifting transformer in $500 \mathrm{kV}$ Grid," in 5th IEEE International Conference on Electric Utility Deregulation, Restructuring and Power Technologies, DRPT 2015, 2016, pp. 1643-1647.

[152] D. De Macedo Correia and D. De Oliveira Camponês Do Brasil, "Pilot project for the evaluation of the sag performance of some Brazilian network busbars," in CIGRE/IEEE PES International Symposium Quality and Security of Electric Power Delivery Systems, CIGRE/PES 2003, 2003, pp. 231-234.

[153] S. Desmettre and A. Szimayer, "Work effort, consumption, and portfolio selection: When the occupational choice matters," Mathematical Methods of Operations 
Research, vol. 74, no. 1, pp. 121-145, 2011.

[154] D. Durović, Ž. Stevanović, and Ž. Stevanović, "Evaluation of the suitability of a project Wind Farm Kostolac using CDM methodology - case study," in 21st International Conference on Efficiency, Cost, Optimization, Simulation and Environmental Impact of Energy Systems, ECOS 2008, 2008, pp. 1169-1176.

[155] M. Kojo, M. Kari, and T. Litmanen, "The socio-economic and communication challenges of spent nuclear fuel management in Finland. The post site selection phase of the repository project in Eurajoki," Progress in Nuclear Energy, vol. 52, no. 2, pp. 168-176, 2010.

[156] C. Li, Y. Liu, and S. Li, "Risk evaluation of Qinghai-Tibet power grid interconnection project for sustainability," Sustainability (Switzerland), vol. 8, no. 1, pp. 1-19, 2016.

[157] H. Li, Z. Lu, Y. Qiao, and Z. Sun, "The fast reliability evaluation method in transmission grid expansion project based on power flow tracing and ward equivalent method," in 2014 International Conference on Power System Technology, POWERCON 2014, 2014, pp. 897-901.

[158] Z. Li, X. Yan, B. Liu, H. Wang, and B. Han, "Application of circuit breaker switching capacitor bank with phase selection in UHV transmission project," in 2014 International Conference on Power System Technology, POWERCON 2014, 2014, pp. 1178-1181.

[159] F. Liang, X. Lv, J. Liu, W. Zhang, X. Liu, and B. Gao, "Evaluation of investment projects on distribution network based on fuzzy algorithms," in 5th Annual IEEE International Conference on Cyber Technology in Automation, Control and Intelligent Systems, IEEE-CYBER 2015, 2015, pp. 761-766.

[160] L. Liu, Z. Jian, W. Qi, Y. Zhao, Y. Wang, and L. Ying, "Theoretical calculation and evaluation of the line losses on UHV AC demonstration project," in 5th Annual IEEE International Conference on Cyber Technology in Automation, Control and Intelligent Systems, IEEE-CYBER 2015, 2015, pp. 1299-1303.

[161] S. Liu, "Economic and risk evaluation on large hydropower station delivery engineering project in Southern China," in 2012 International Conference on Information Management, Innovation Management and Industrial Engineering, ICIII 2012, 2012, vol. 2, pp. 106-109.

[162] N. Loukeris, D. Donelly, A. Khuman, and Y. Peng, "A numerical evaluation of meta-heuristic techniques in portfolio optimisation," Operational Research, vol. 9, no. 1, pp. 81-103, 2009.

[163] G. Lu, H. Luan, W. He, and Y. Ma, "Decision model research on engineering project arrangement of power grid enterprise group based on input and output efficiency evaluation," in International Conference on Engineering Technology and Application, ICETA 2015, 2015, vol. 22. 
[164] Y. Lu, C. Niu, X. Xu, and M. Xing, "Power grid project cost intelligent evaluation technology based on probability statistics," Open Cybernetics and Systemics Journal, vol. 8, no. 1, pp. 1129-1133, 2014.

[165] H. Mi and S.-G. Zhang, "Dynamic portfolio selection for loss-averse investors with wealth constraints," Xitong Gongcheng Lilun yu Shijian/System Engineering Theory and Practice, vol. 33, no. 5, pp. 1107-1115, 2013.

[166] Q. Mu, M. Wang, N. Zeng, W. Jiang, and H. Wang, "Selection of control strategy for on-line deblocking of converter units used in UHVDC power transmission project," Dianwang Jishu/Power System Technology, vol. 35, no. 4, pp. 8-13, 2011.

[167] M. Nagle, S. Kolluri, and S. K. Agarwal, "Implementation of probabilistic methods for ranking transmission projects," in 2004 International Conference on Probabilistic Methods Applied to Power Systems, 2004, pp. 900-905.

[168] J. X. Qi, S. L. Liu, and Z. Y. Sun, "Study on post-evaluation for the power transmission and transformation project based on AHP-fuzzy comprehensive," in 3rd International Conference on Materials Science and Information Technology, MSIT 2013, Beijing, China, 2013, vol. 756-759, pp. 2668-2672.

[169] D. Qiushi, W. Guan-Nan, and C. Li, "Project evaluation of jilin rural power grid reformation based on rough set and support vector machine," in 14th International Symposium on Distributed Computing and Applications for Business, Engineering and Science, DCABES 2015, 2016, pp. 489-492.

[170] G. Quek and C. Atkinson, "Portfolio selection in discrete time with transaction costs and power utility function: A perturbation analysis," Applied Mathematical Finance, vol. 24, no. 2, pp. 77-111, 2017.

[171] A. Shankar and K. Varghese, "Evaluation of location based management system in the construction of power transmission and distribution projects," in 30th International Symposium on Automation and Robotics in Construction and Mining, ISARC 2013, Held in Conjunction with the 23rd World Mining Congress, 2013, pp. $1447-1455$.

[172] G. S. Tian, J. C. Liu, J. J. Zhou, J. L. Liu, and B. Li, "Efficiency evaluation model of power transmission \& transformation project investment based on AHP-Fuzzy method," in 2013 2nd International Conference on Energy and Environmental Protection, ICEEP 2013, East Inner Mongolia, China, 2013, vol. 732-733, pp. 1303-1307.

[173] F. J. Wang and Y. Lu, "Fuzzy analytic hierarchy process based comprehensive evaluation of distribution materials standardization projects," in 5th International Symposium on Project Management, ISPM 2017, 2017, pp. 668-675.

[174] J. Wang, L. Zhang, and Y. Wang, "Research and practice on the social evaluation of power grid construction project," in 2006 China International Conference on Electricity Distribution, CICED 2006, 2006, no. 527 CP, pp. 250-255. 
[175] Y.-L. Wang, Y.-J. Li, and Q.-C. Xu, "Application of improved radar chart in comprehensive evaluation of power transmission and transformation project," Dianli Xitong Baohu yu Kongzhi/Power System Protection and Control, vol. 40, no. 5, pp. 119-123, 2012.

[176] Y. Wang and Y. Li, "Comprehensive evaluation of power transmission and transformation project based on improved radar chart," in 2011 International Conference on Energy, Environment and Sustainable Development, ICEESD 2011, Beijing, China, 2012, vol. 354-355, pp. 1068-1072.

[177] G. Wei, Y. Yang, J. Wang, and B. Zhou, "Technical post-evaluation on power transmission and transformation project based on comprehensive evaluation method," Dianwang Jishu/Power System Technology, vol. 34, no. 3, pp. 112-116, 2010.

[178] J. Wen, J. Wang, L. Wang, W.-Y. Yin, and B.-H. Liu, "Evaluation of capacitor commutated converter HVDC for Qinghai-Xizhang interconnection project," in 9th IET International Conference on AC and DC Power Transmission, ACDC 2010, Beijing, China, 2010, no. 570 CP.

[179] K. Wong, "Prioritization of underground transmission cable renewal projects in power electric utility companies," in 2014 IEEE Power and Energy Society General Meeting, 2014, vol. 2014, no. October, pp. 1-5.

[180] H. Wu and Y. Zeng, "Multi-period mean-variance portfolio selection in a regimeswitching market with a bankruptcy state," Optimal Control Applications and Methods, vol. 34, no. 4, pp. 415-432, 2013.

[181] K. Xu et al., "Multi-attribute comprehensive evaluation method for power transmission and transformation projects," in 2013 2nd International Conference on Sustainable Energy and Environmental Engineering, ICSEEE 2013, 2014, vol. 521, pp. 245-251.

[182] F. Yan, M. Dai, and Y.-J. Wei, "Research on risk evaluation of power network planning project based on BP neural network," in 2010 3rd International Conference on Advanced Computer Theory and Engineering, ICACTE 2010, 2010, vol. 6, pp. V6274-V6277.

[183] H. Zhai, X. Lu, and H. Qiao, "Research of cost management mode of power transmission project and its evaluation," in WIT Transactions on Information and Communication Technologies, 2014, vol. 46, pp. 9-14.

[184] P. Zhang, M. Graham, and D. Ramsay, "Prioritization of transmission projects using EPRI Probabilistic Risk Assessment program," in 2009 Asia-Pacific Power and Energy Engineering Conference, APPEEC 2009, 2009.

[185] X. Zhang, T. K. Siu, and Q. Meng, "Portfolio selection in the enlarged Markovian regime-switching market," SIAM Journal on Control and Optimization, vol. 48, no. 5, pp. 3368-3388, 2010. 
[186] H. Zhao and S. Guo, "Risk evaluation on UHV power transmission construction project based on AHP and FCE method," Mathematical Problems in Engineering, vol. 2014, 2014.

[187] H. Zhao and N. Li, "Risk evaluation of a uhv power transmission construction project based on a cloud model and fce method for sustainability," Sustainability (Switzerland), vol. 7, no. 3, pp. 2885-2914, 2015.

[188] L. X. Zheng, "Research on comprehensive post-evaluation of electric transmission project based on fuzzy AHP analysis method," in 2nd International Conference on Automatic Control and Mechatronic Engineering, ICACME 2013, vol. 415. Electrical and Electronic Engineering School, North China Electric Power University, Beijing, China, pp. 280-286, 2013.

[189] X. Li, X. Zhu, Q. Liao, and H. Sun, "Evaluation of power transmission and transformation projects using fuzzy multi-layer models," International Journal of Simulation: Systems, Science and Technology, vol. 17, no. 47, pp. 21.1-21.6, 2016.

[190] A. Morton, J. Keisler, and A. Salo, "Multicriteria portfolio decision analysis for project selection," in International Series in Operations Research \& Management Science, vol. 233, F. J. (eds) Greco S., Ehrgott M., Ed. New York, US.: Springer, 2016.

[191] J. D. Linton, S. T. Walsh, and J. Morabito, "Analysis, ranking and selection of R\&D projects in a portfolio," $R$ and D Management, vol. 32, no. 2, pp. 139-148, 2002.

[192] K. L. Poh, B. W. Ang, and F. Bai, "A comparative analysis of R\&D project evaluation methods," $R$ and D Management, vol. 31, no. 1, pp. 63-73, 2001.

[193] G. Gottardi, R. Maglione, F. Donati, and P. Broccia, "Ranking R\&D projects in the petroleum area: New tools for economic evaluation," European Petroleum Conference (EUROPEC). Soc Pet Eng (SPE), Univ of Padova, Padova, Italy, pp. 587-593, 2000.

[194] C. Carlsson, R. Fullér, and P. Majlender, "A fuzzy approach to R\&D project selection," in Joint 4th Conference of the European Society for Fuzzy Logic and Technology, EUSFLAT 2005 and 11th French Days on Fuzzy Logic and Applications, LFA 2005, 2005, pp. 536-540.

[195] X. Y. Liu, W. G. Fang, and F. J. Wei, "Multi-stage evaluation of R\&D IT projects Based on compound options," in 1st International Forum of Information Systems Frontiers, IFISF and 2nd IFIP TC8.9 International Conference on Research and Practical Issues of Enterprise Information Systems, CONFENIS 2007. Beijing, China, pp. 413-419, 2008.

[196] S. Managi, Z. Zhang, and S. Horie, "A real options approach to environmental R\&D project evaluation," Environmental Economics and Policy Studies, vol. 18, no. 3, pp. 359-394, 2016.

[197] A. Ç. Tolga, "Fuzzy multicriteria R\&D project selection with a real options 
valuation model," Journal of Intelligent and Fuzzy Systems, vol. 19, no. 4-5, pp. 359-371, 2008.

[198] A. C. Tolga and C. Kahraman, "Fuzzy multiattribute evaluation of R\&D projects using a real options valuation model," International Journal of Intelligent Systems, vol. 23, no. 11, pp. 1153-1176, 2008.

[199] A. Ç. Tolga and C. Kahraman, "A new fuzzy real options valuation model: Its application to multicriteria R\&D project selection," in Computational Intelligence in Decision and Control - 8th International FLINS Conference, Istanbul, Turkey, 2008, pp. 641-646.

[200] L. A. M. Leite, L. P. Santiago, and J. P. Teixeira, "Real options under Knightian uncertainty for economic evaluation of research and development (R\&D) projects," Producao, vol. 25, no. 3, pp. 641-656, 2015.

[201] J. Wang and W.-L. Hwang, “A fuzzy set approach for R\&D portfolio selection using a real options valuation model,” Omega, vol. 35, no. 3, pp. 247-257, 2007.

[202] E. E. Karsak, "A generalized fuzzy optimization framework for R\&D project selection using real options valuation," in ICCSA 2006: International Conference on Computational Science and Its Applications, Istanbul, Turkey, vol. 3982 LNCS. Springer Verlag, Istanbul, Turkey, pp. 918-927, 2006.

[203] H.-Z. Zeng and G.-M. Hou, "Evaluation of electric vehicle R\&D project based on real option theory -in the case of TESLA," Beijing Ligong Daxue Xuebao/Transaction of Beijing Institute of Technology, vol. 34, pp. 196-199, 2014.

[204] F. Hassanzadeh, M. Collan, and M. Modarres, "A technical note on 'A fuzzy set approach for R\&D portfolio selection using a real options valuation model' by Wang and Hwang (2007)," Omega, vol. 39, no. 4, pp. 464-465, 2011.

[205] D. Zhu, X. Wang, and R. Ren, "A heuristics R\&D projects portfolio selection decision system based on data mining and fuzzy logic," in 2010 International Conference on Intelligent Computation Technology and Automation, ICICTA 2010, vol. 1. Fushun, Liaoning, China, pp. 118-121, 2010.

[206] T. Yao, "Dynamic R\&D projects selection: The role of uncertainty and managerial flexibility," in 2006 IIE Annual Conference and Exposition, PA United States, 2006.

[207] T. Silva, M. Jian, and Y. Chen, "Process analytics approach for R\&D project selection," ACM Transactions on Management Information Systems, vol. 5, no. 4, 2014.

[208] J. D. Linton, S. T. Walsh, B. A. Kirchhoff, J. Morabito, and M. Merges, "Selection of R\&D projects in a portfolio," 2000 IEEE International Engineering Management Conference. IEEE, Polytechnic Univ, United States, pp. 506-511, 2000.

[209] W. Bitman and N. Sharif, "A conceptual framework for ranking R\&D projects," IEEE Transactions on Engineering Management, vol. 55, no. 2, pp. 267-278, 2008. 
[210] A. J. Da Silva Neves and R. Camanho, "The use of AHP for IT project priorization - A case study for oil \& gas Company," Procedia Computer Science, vol. 55, no. Itqm, pp. 1097-1105, 2015.

[211] S. S. Kumar, "AHP-based formal system for R\&D project evaluation," Journal of Scientific and Industrial Research, vol. 63, no. 11, pp. 888-896, 2004.

[212] C.-C. Huang, P.-Y. Chu, and Y.-H. Chiang, "A fuzzy AHP application in government-sponsored R\&D project selection," Omega, vol. 36, no. 6, pp. 10381052, 2008.

[213] M. Habib, R. Khan, and J. L. Piracha, "Analytic network process applied to R\&D project selection," 2009 International Conference on Information and Communication Technologies, ICICT 2009. Lahore, Pakistan, pp. 274-280, 2009.

[214] L. M. Meade and A. Presley, "R\&D project selection using the analytic network process," IEEE Transactions on Engineering Management, vol. 49, no. 1, pp. 5966, 2002.

[215] C. Verbano and A. Nosella, "Addressing R\&D investment decisions: A cross analysis of R\&D project selection methods," European Journal of Innovation Management, vol. 13, no. 3, pp. 355-379, 2010.

[216] S. Rama Mohan and A. Ramakrishna Rao, "R and D project prioritisation model for public research institutes," Journal of Scientific and Industrial Research, vol. 61, no. 12, pp. 1033-1038, 2002.

[217] L. P. Santiago and P. Vakili, "Optimal project selection and budget allocation for R\&D portfolios," in PICMET '05: Portland International Conference on Management of Engineering and Technology, 2005, pp. 275-281.

[218] D. Kuchta, "A fuzzy model for R\&D project selection with benefit, outcome and resource interactions," Engineering Economist, vol. 46, no. 3, pp. 164-180, 2001.

[219] Y. Changsheng, "A decision-making approach for R\&D project selection in a fuzzy environment," 2008 International Seminar on Business and Information Management, ISBIM 2008, vol. 1. Jinhua, Zhejiang, China, pp. 372-375, 2009.

[220] D. Luo and L. Xu, "The grey B-S model of R\&D project evaluation," in $20103 r d$ International Conference on Artificial Intelligence and Education, ICAIE 2010, 2010, pp. 414-417.

[221] D.-M. Zhu, T. Zhang, X.-T. Wang, and D.-L. Chen, "Developing an R\&D projects portfolio selection decision system based on fuzzy logic," International Journal of Modelling, Identification and Control, vol. 8, no. 3, pp. 205-212, 2009.

[222] F. Hassanzadeh, M. Collan, and M. Modarres, "A practical approach to R\&D portfolio selection using the fuzzy pay-off method," IEEE Transactions on Fuzzy Systems, vol. 20, no. 4, pp. 615-622, 2012.

[223] D. Gourc, S. Bougaret, and G. Lacoste, "Evaluation of development strategies of 
new products in a situation of uncertainty. The case of a pharmaceutical research and development project," Journal Europeen des Systemes Automatises, vol. 38, no. 7-8, pp. 847-872, 2004.

[224] R. P. Mohanty, R. Agarwal, A. K. Choudhury, and M. K. Tiwari, "A fuzzy ANPbased approach to R\&D project selection: A case study," International Journal of Production Research, vol. 43, no. 24, pp. 5199-5216, 2005.

[225] P. Godinho, J. P. Costa, J. Fialho, and R. Afonso, "Some issues about the application of the analytic hierarchy process to R\&D project selection," Global Business and Economics Review, vol. 13, no. 1, pp. 26-41, 2011.

[226] S. Roper, N. Hewitt-Dundas, and J. H. Love, "An ex ante evaluation framework for the regional benefits of publicly supported R\&D projects," Research Policy, vol. 33, no. 3, pp. 487-509, 2004.

[227] S. Coldrick, P. Longhurst, P. Ivey, and J. Hannis, "An RD options selection model for investment decisions," Technovation, vol. 25, no. 3, pp. 185-193, 2005.

[228] M. S. Pfitzner and R. Quadros, "R\&D portfolio management: The case study of a big energy company in Brazil," PICMET 2011 - Portland International Center for Management of Engineering and Technology, pp. 1-16, 2011.

[229] R. W. Saaty, "The analytic hierarchy process-what it is and how it is used," Mathematical Modelling, vol. 9, no. 3-5, pp. 161-176, 1987.

[230] R. Neshati and T. U. Daim, "Participation in technology standards development: A decision model for the information and communications technology (ICT) industry," The Journal of High Technology Management Research, vol. 28, no. 1. pp. 47-60, 2017.

[231] S. Riddell and W. A. Wallace, "The use of fuzzy logic and expert judgment in the R\&D project portfolio selection process," International journal of technology management, vol. 53, no. 2-4, pp. 238-256, 2011.

[232] E. Gibson, "A measurement system for science and engineering research center performance evaluation," Engineering and Technology Management - Portland State University, Oregon, 2016.

[233] B. B. Brown, "DELPHI process: A methodology used for the elicitation of opinions of experts," no. February. Santa Monica, California Introduction, 1968.

[234] Federal Highway Administration U.S. Department of Transportation, "Use of expert panels in developing land use forecasts," Proceedings of a Peer Exchange Sponsored by the Travel Model Improvement Program. 2002.

[235] R. Abotah, "Evaluation of energy policy instruments for the adoption of renewable energy : Case of wind energy in the Pacific Northwest," Portland State University, Oregon, USA, 2014.

[236] D. J. Weiss and J. Shanteau, "Empirical assessment of expertise," Human Factors: 
The Journal of the Human Factors and Ergonomics Society, vol. 45, no. 1, pp. 104 116, 2003.

[237] J. Estep, "Development of a technology transfer score for evaluating research proposals: Case study of demand response technologies in the Pacific Northwest," Engineering and Technology Management, Portland State University, Oregon, USA, 2016.

[238] TMIP, "Use of expert panels in developing land use forecasts," 2002.

[239] W. L. Stitt-Gohdes, T. B. Crews, and T. B. Crews, "The Delphi technique: A research strategy for career and technical education," Journal of Career and Technical Education, vol. 20, no. 2, May 2004.

[240] Q. Jones et al., "Information overload and the message dynamics of online interaction spaces: A theoretical model and empirical exploration," Information Systems Research, vol. 15, no. 2, pp. 194-210, Jun. 2004.

[241] K. Phan, "Innovation measurement: A decision framework to determine innovativeness of a company," Engineering and Technology Management, Portland State University, Oregon, USA, 2013.

[242] Qualtrics, “Qualtrics.” Provo, Utah, USA, 2019.

[243] C. Okoli and S. D. Pawlowski, "The Delphi method as a research tool: an example, design considerations and applications," Information \& Management, vol. 42, no. 1, pp. 15-29, Dec. 2004.

[244] E. Garces, K. van Blommestein, J. Anthony, J. Hillegas-Elting, T. Daim, and B. S. Yoon, "Technology domain analysis: A case of energy-efficient advanced commercial refrigeration technologies," Sustainable Production and Consumption, vol. 12, no. December 2016, pp. 221-233, 2017.

[245] M. Abbas, "Consistency analysis for judgment quantification in Hierarchical Decision Model," Portland State University, Oregon, USA, 2016.

[246] ETM PSU-PCM, "HDM Softwarer Version: Beta 2.0.” ETM, Portland, Oregon, USA, 2016.

[247] H. Chen and D. F. Kocaoglu, "A sensitivity analysis algorithm for hierarchical decision models," European Journal of Operational Research, vol. 185, no. 1, pp. 266-288, Feb. 2008.

[248] J. Seeber, "Project Selection Criteria : How to Play it Right," 2011.

[249] B. W. F. Depoorter, "5400 REGULATION OF NATURAL MONOPOLY," Center for Advanced Studies in Law and Economics, University of Ghent, pp. 498-532, 1999.

[250] F. T. Lorne and L. W. C. Lai, "Schumpeterian Innovation for Regulated Natural Monopoly as a Corporate Strategy," in International Conference on Information, 
Services and Management Engineering, 2011, vol. 2011.

[251] Federal Energy Regulatory Commision, "FERC: Electric power markets." [Online]. Available: https://www.ferc.gov/market-assessments/mkt-electric/overview.asp. [Accessed: 08-Jun-2020].

[252] Department of Energy, "Energy Department names Elliot Mainzer Bonneville Power Administration administrator." [Online]. Available: https://www.energy.gov/articles/energy-department-names-elliot-mainzerbonneville-power-administration-administrator. [Accessed: 15-May-2020].

[253] U.S. Department of Energy, DOE Transition 2016 Organization Overviews Book Three, DOE. DOE, 2016.

[254] Bonneville Power Administration, "BPA.GOV - About us." [Online]. Available: https://www.bpa.gov/news/AboutUs/Pages/default.aspx. [Accessed: 15-May2020].

[255] U.S. Energy Information Administration, "Federal Power Marketing Administrations operate across much of the United States," Today in Energy, 14Mar-2017. [Online]. Available: https://www.eia.gov/todayinenergy/detail.php?id=11651.

[256] D. Markham, "Power Marketing Administrations poised to make another big contribution to america's progress," Energy.gov. 15-Apr-2012.

[257] T. L. Saaty, "That is not the analytic hierarchy process: What the AHP is and what it is not," Journal of Multi-Criteria Decision Analysis, vol. 6, no. 6, pp. 324-335, 1997. 


\section{APPENDIX A: Research Instrument RI1: Criteria Decision Model Validation}

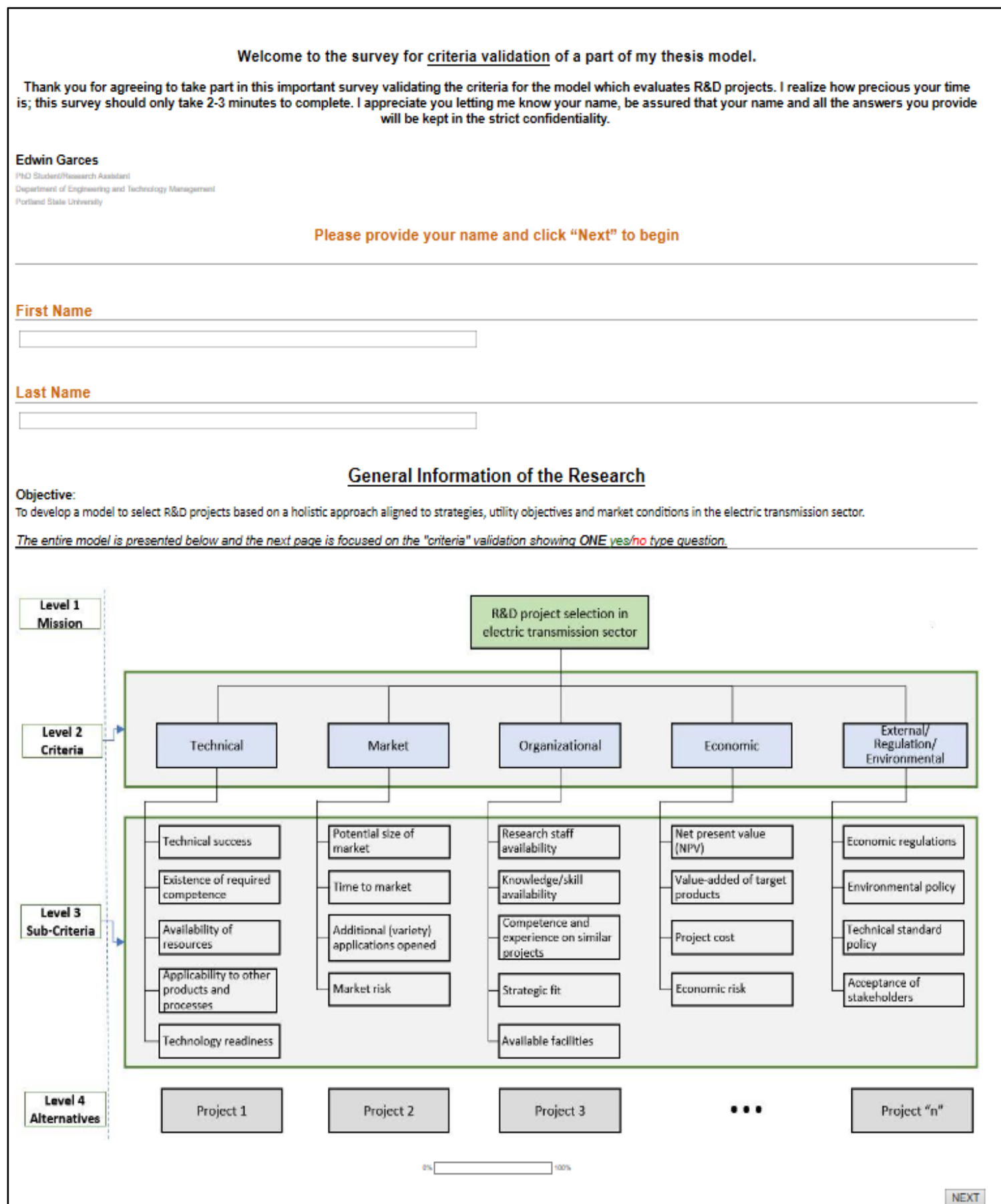




\section{Criteria Validation}

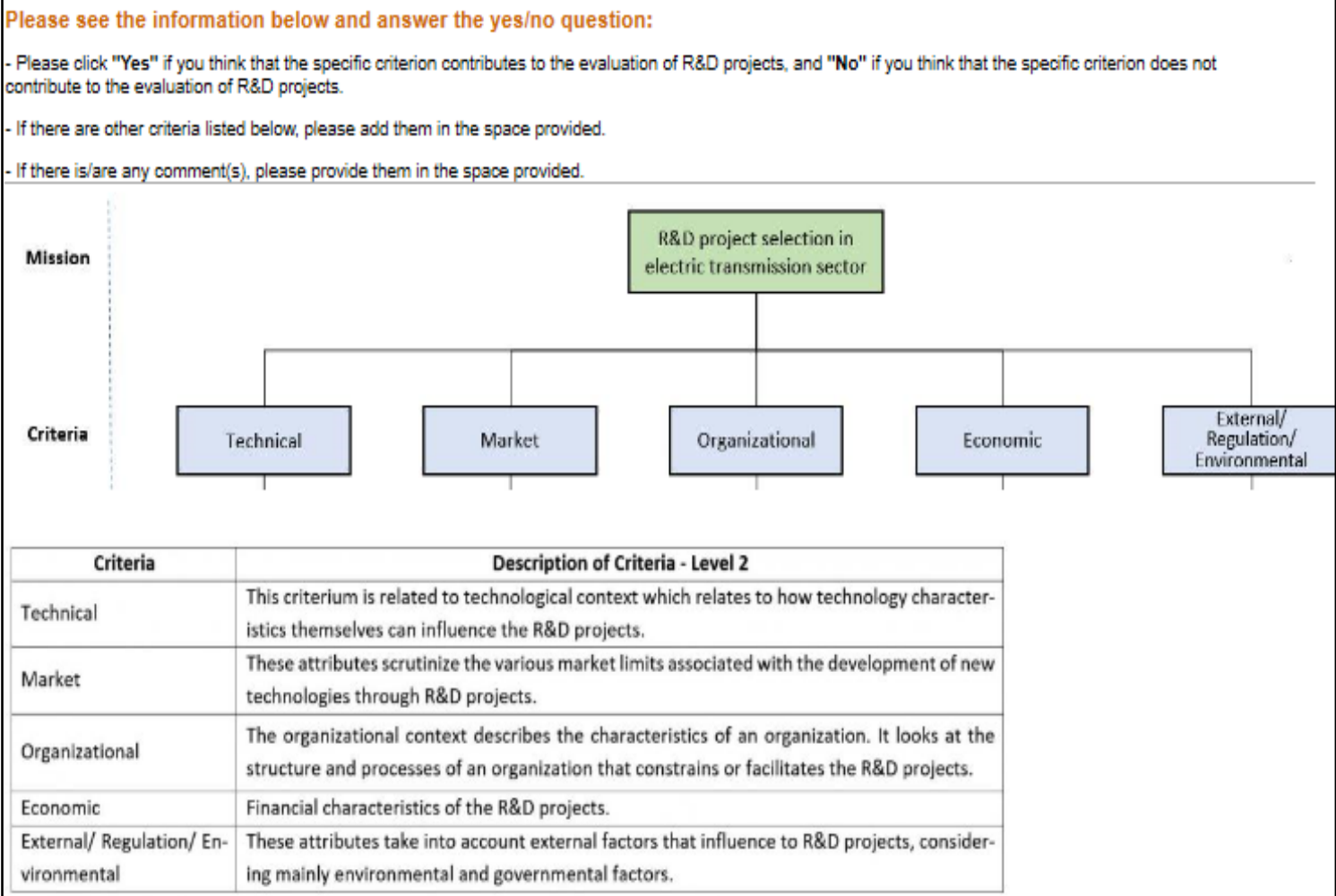

Please identify the criteria indicator that in your judgment, contribute to the R\&D project selection in the Electric Transmission Sector

\begin{tabular}{l|cc} 
& \multicolumn{2}{|c}{ Click to writi } \\
\hline - Technical & Yos & No \\
- Market & 0 & 0 \\
- Organizational & 0 & 0 \\
- Economic & 0 & 0 \\
- External / & 0 & 0 \\
Regulation / & 0 & 0 \\
Environmental & &
\end{tabular}

Please feel free to add a criterion that in your judgment, contributes to the mission:

Comment: 


\section{APPENDIX B: Research Instrument RI2: Sub-Criteria Decision Model Validation}

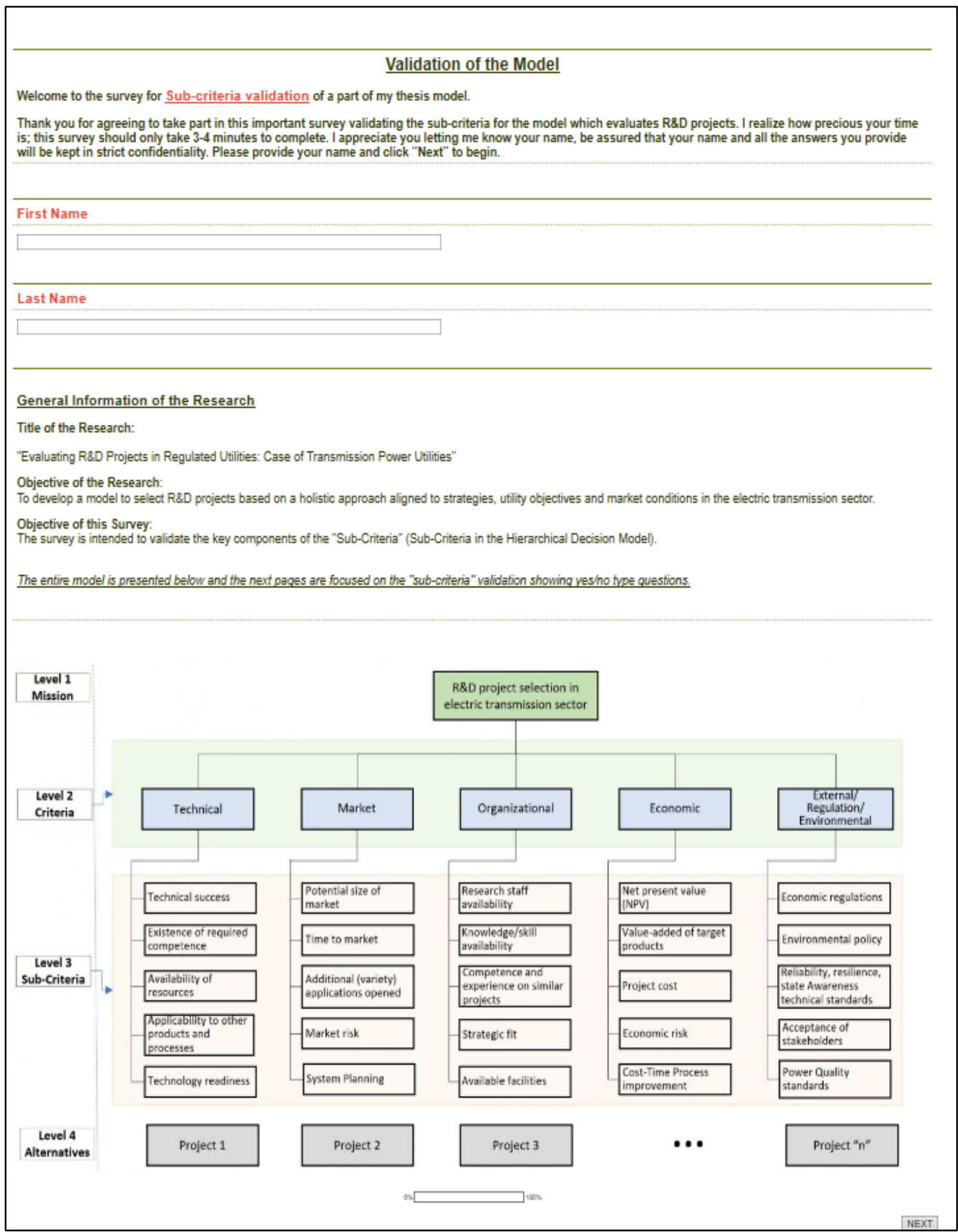




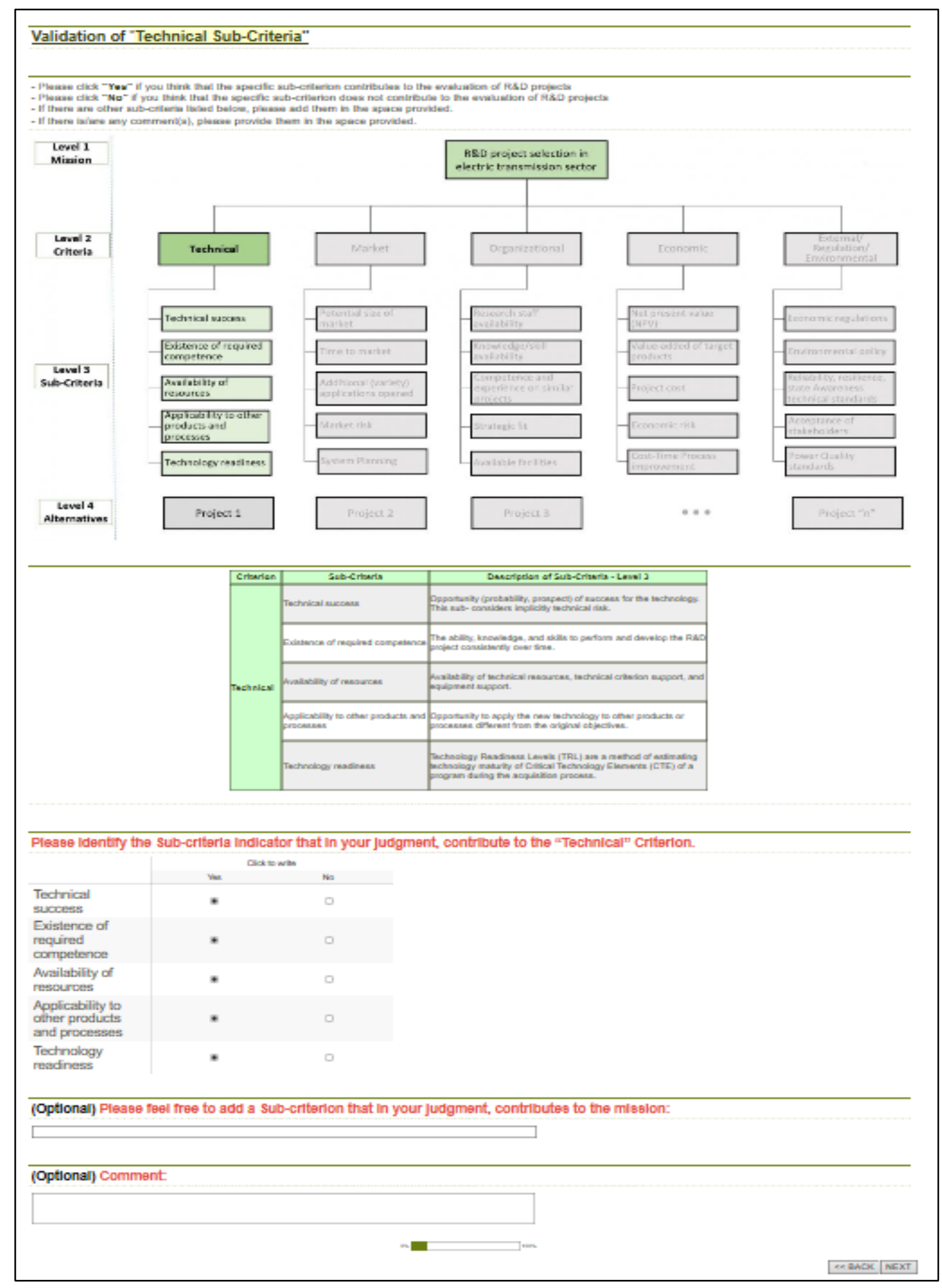




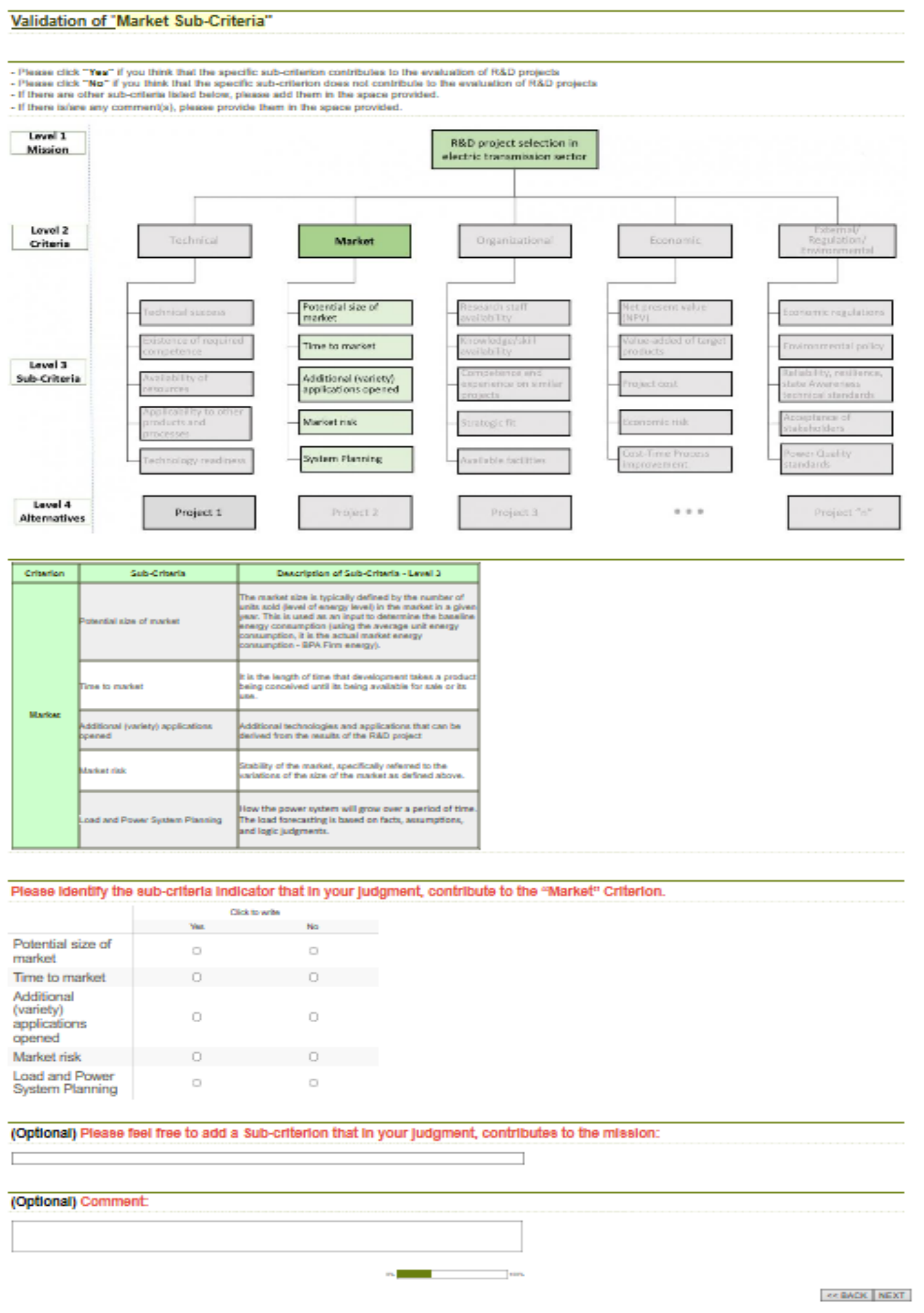




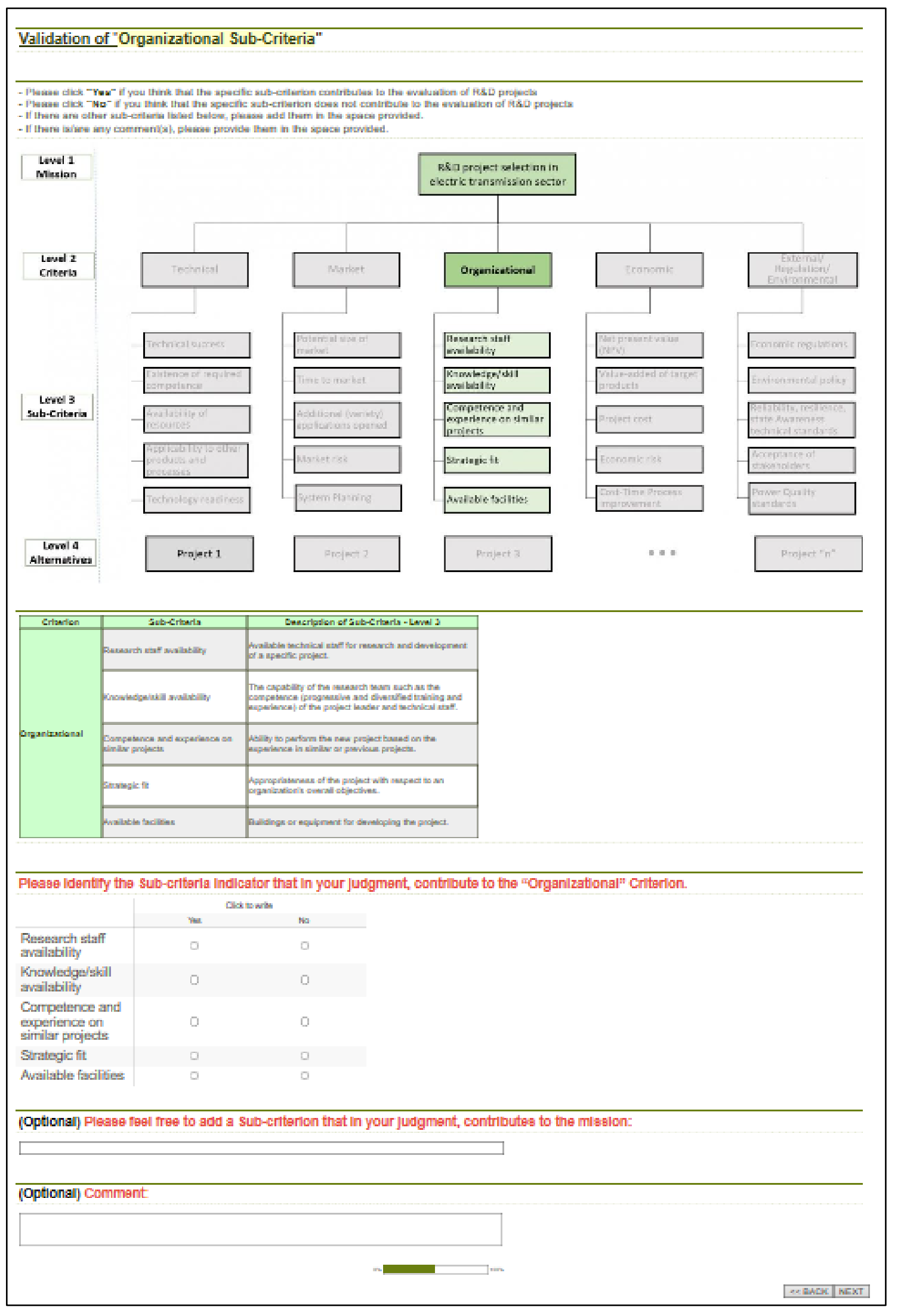




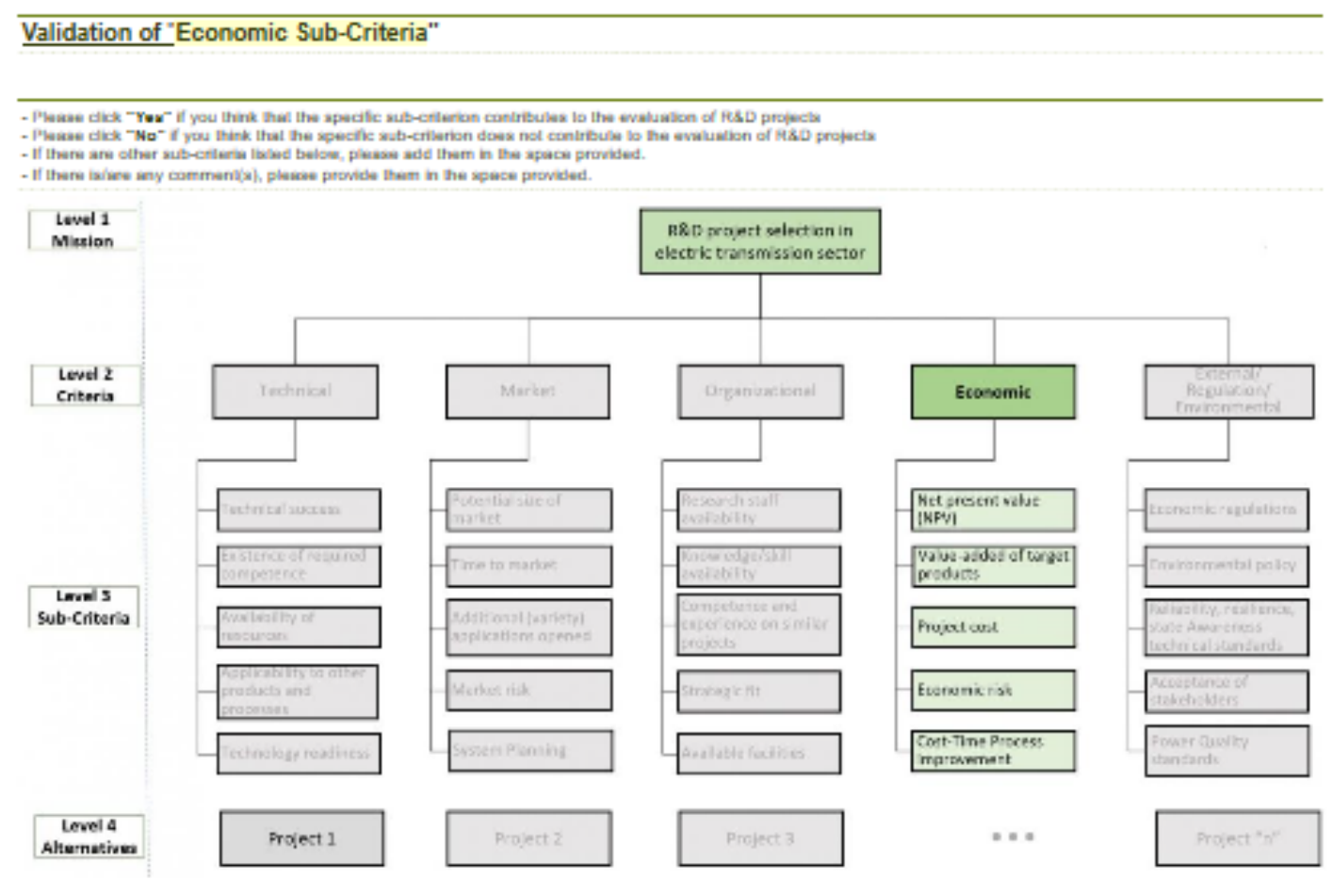

\begin{tabular}{|c|c|c|}
\hline Emarlen & Euachitarts & 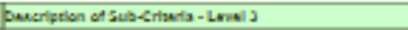 \\
\hline \multirow{5}{*}{ Eeenamle } & 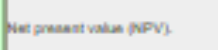 & 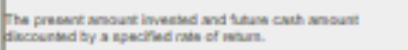 \\
\hline & Valce-sidied of twget posducts. & 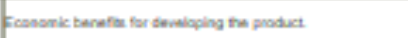 \\
\hline & Propect cons & 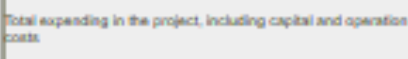 \\
\hline & Peconemik dak & 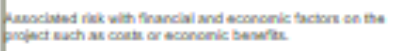 \\
\hline & $\begin{array}{l}\text { Caut-Time Praceset } \\
\text { Inarovement }\end{array}$ & 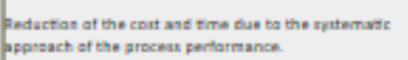 \\
\hline
\end{tabular}

Please Identiry the Sub-criterla indlcator that in your judgment, contribute to the "Economic" Criterion.

\begin{tabular}{|c|c|c|}
\hline & \multicolumn{2}{|c|}{ Dak wewh } \\
\hline & $m$ & $\mathrm{Na}$ \\
\hline $\begin{array}{l}\text { Net present value } \\
\text { (NPV). }\end{array}$ & 0 & 0 \\
\hline $\begin{array}{l}\text { Value-addoed of } \\
\text { target products }\end{array}$ & 0 & 0 \\
\hline Project cost & 0 & 0 \\
\hline Econornic risk & 0 & 0 \\
\hline $\begin{array}{l}\text { Cost-Time } \\
\text { Process } \\
\text { improvernent }\end{array}$ & 0 & 0 \\
\hline
\end{tabular}

(Optional) Please feel free to add a Sub-criterion that lin your judgment, contributes to the mission: 


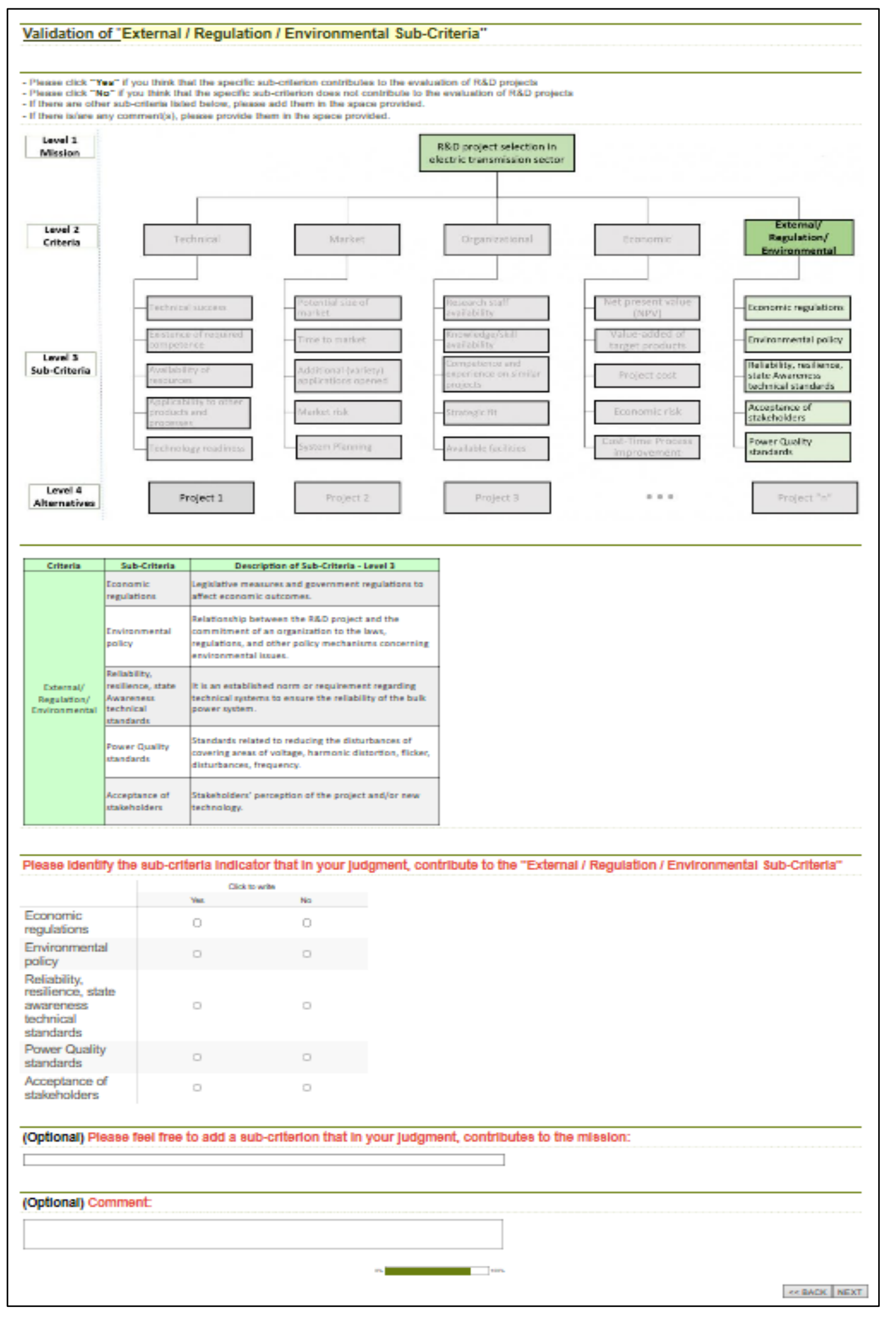




\section{APPENDIX C: Research Instrument RI3: Criteria Decision Model Quantification}

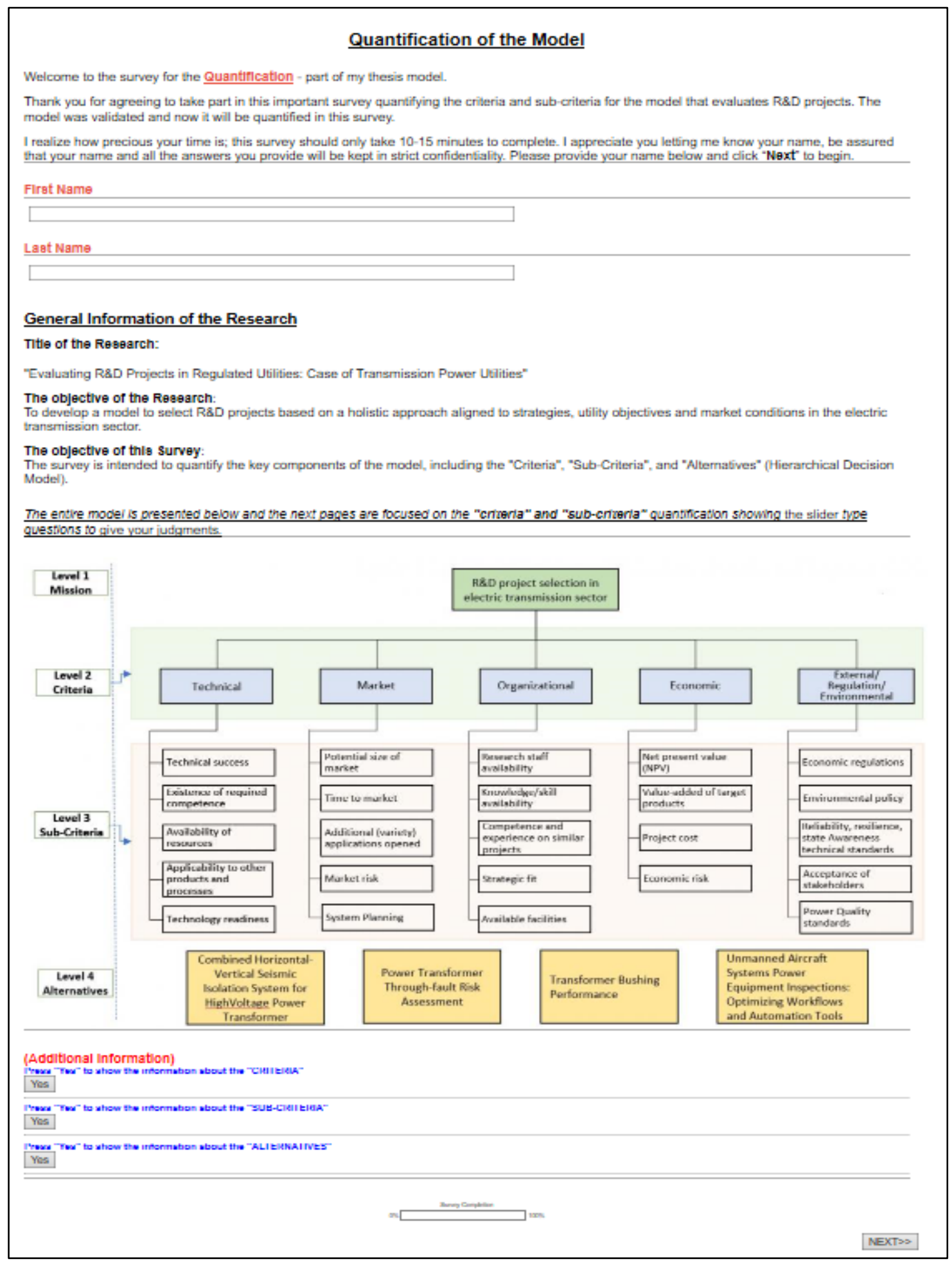




\section{Instructions}

A Hierarchical Decision Model (HDM) is used in this survey. In this method, two elements are compared with each other at a time. The expert allocates a total of 100 points to the two elements in the proportion of their relative importance to the objective.

- You can drag the slider left or right to give your judgments. If you prefer one element compared to the other one in the pair, please bring the slider closer to the preferred element.

- The description of each item can be obtained by locating the pointer mouse on the element.

\section{Example:}

- If the importance of $A$ and $B$ are the same, both get 50 points. This is the case regardless of whether both are extremely important, mildly important or unimportant. If $\mathrm{A}$ is $1 / 4$ as important as $\mathrm{B}$, A gets 20 points, $\mathrm{B}$ gets 80 points. Zero is not used in the pairwise comparisons. If the importance of $A$ is negligible in comparison to $B, A$ gets 1 point, $B$ gets 99 points.

\section{Wustration:}

. When you move the slider, the 100 points allocation and the ratio of the relative importance of $A$ to $B$ are shown automatically. If $\mathrm{A}$ is 3 times as important as $\mathrm{B}, \mathrm{A}$ gets 75 points, $\mathrm{B}$ gets 25 points.

Please, see the animated illustration below:

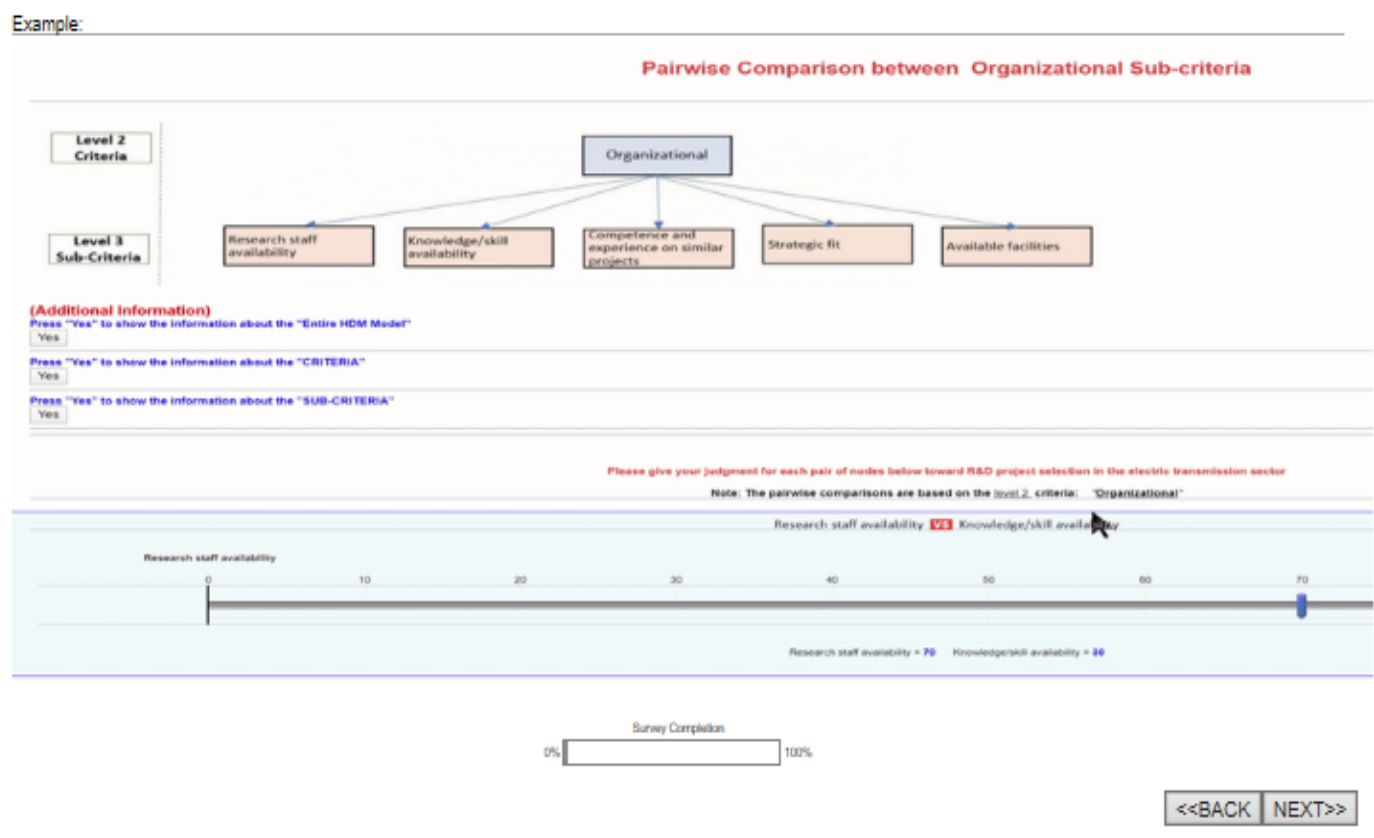




\section{Pairwise Comparison between Criteria}

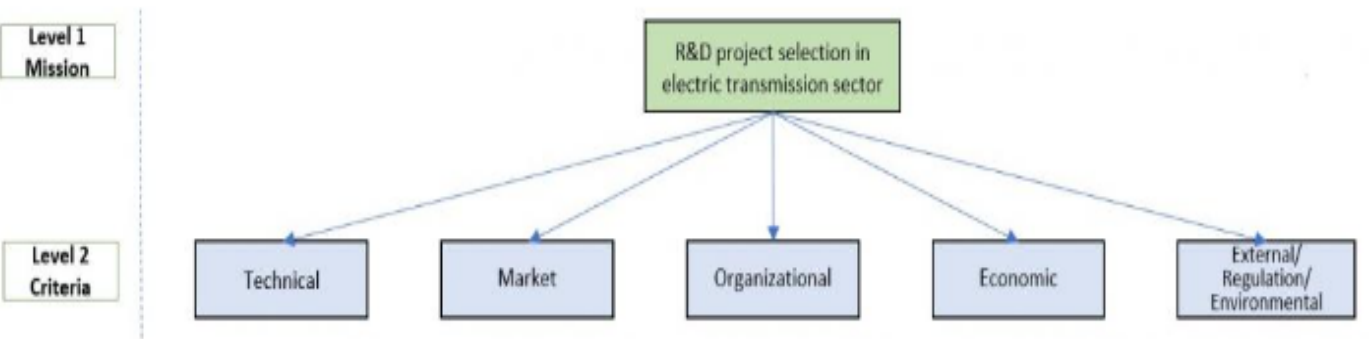

(Additional Information)

Pregs "YeB" to ahow the Information about the "Entire HDM Model"

Yes

Pregs " $Y$ e日" to ghow the Information about the "CRITERIA"

Yes

Please give your judgment for each pair of nodes (CRITERIA) below toward R\&D project selection in the electric transmission sector

Market V3 Tectrical

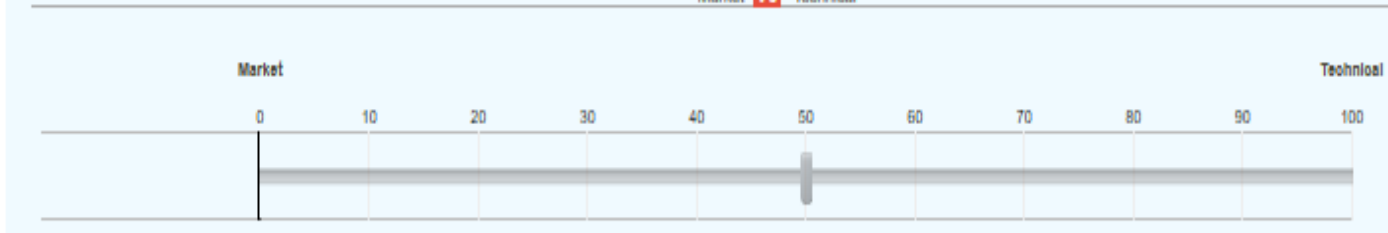

Markat $=0$ Tochnical $=0$

Organizational V8 Tectrical

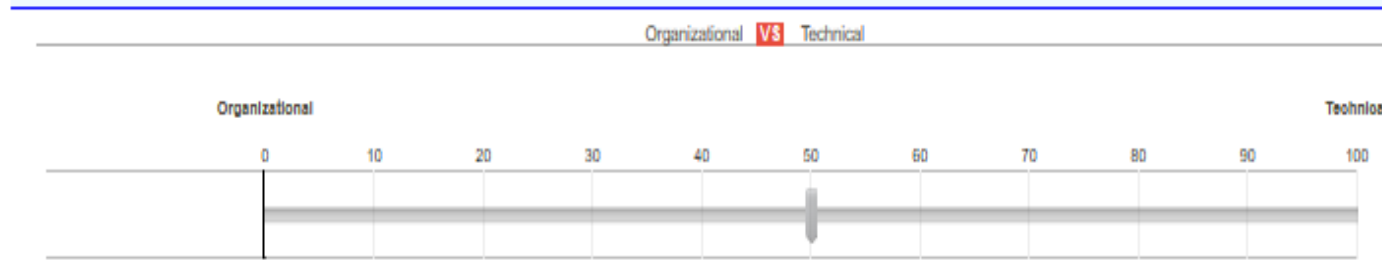

Organlizations $=0 \quad$ Tachical $=0$

Econarnic V3 Tectnical

Eoonomilo

$10 \quad 20 \quad 30$

40

so

60

70

80

90

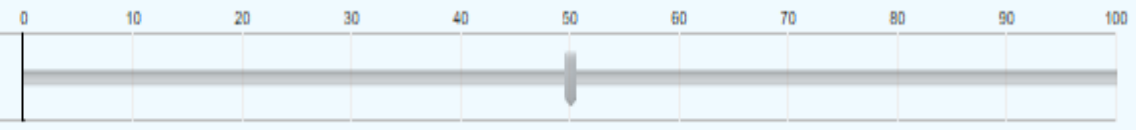

Econamic $=0$ Tachnical $=0$ 


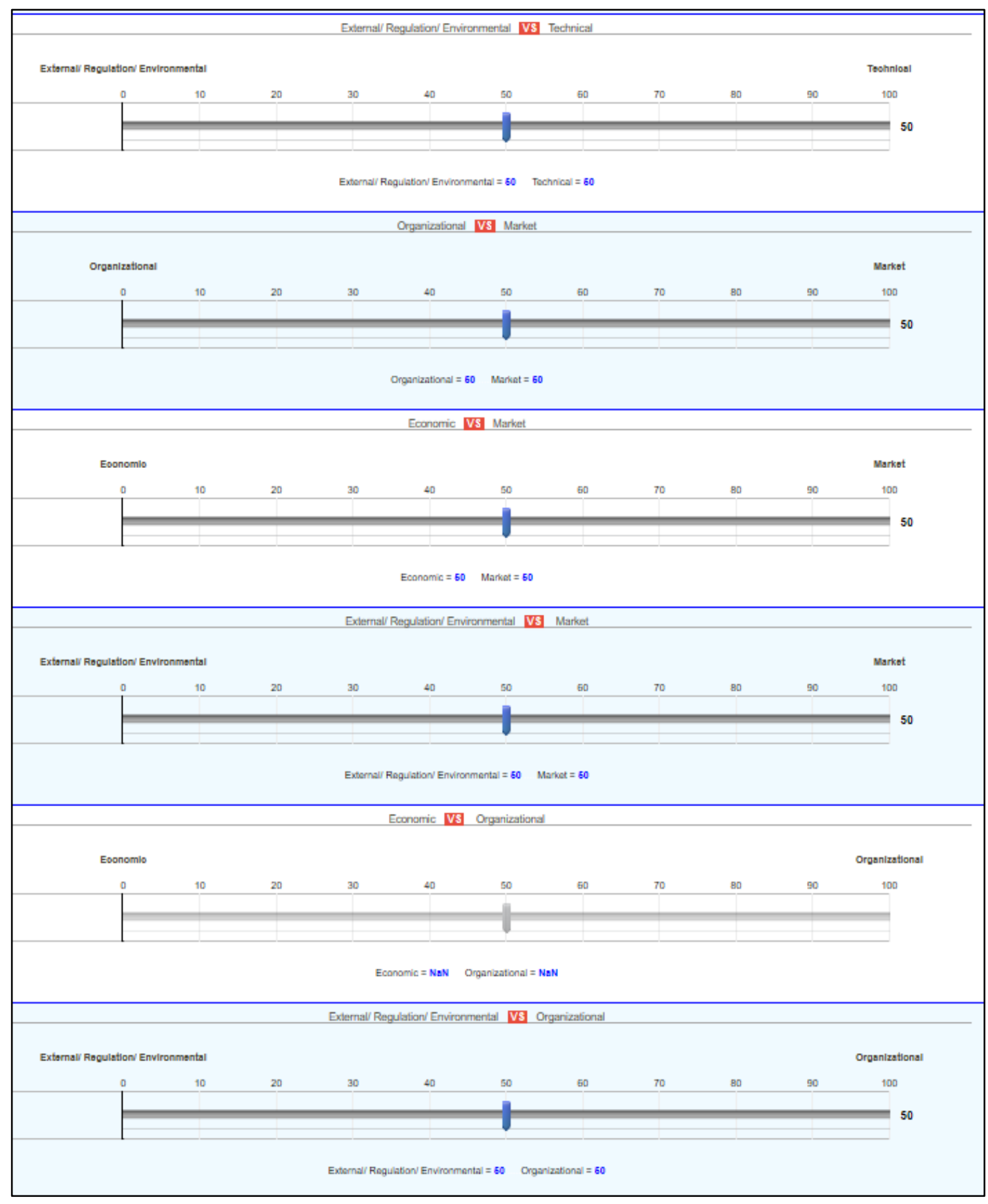

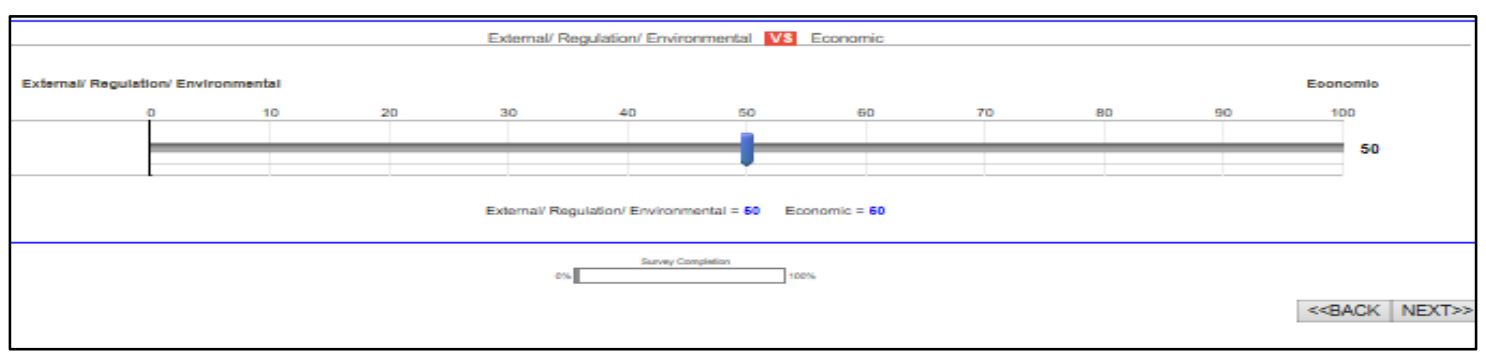




\section{APPENDIX D: Research Instrument RI4: Sub-criteria Decision Model Quantification}

(This instrument is taken from Qualtrics and kept the format - Example for the Technical Criterion)

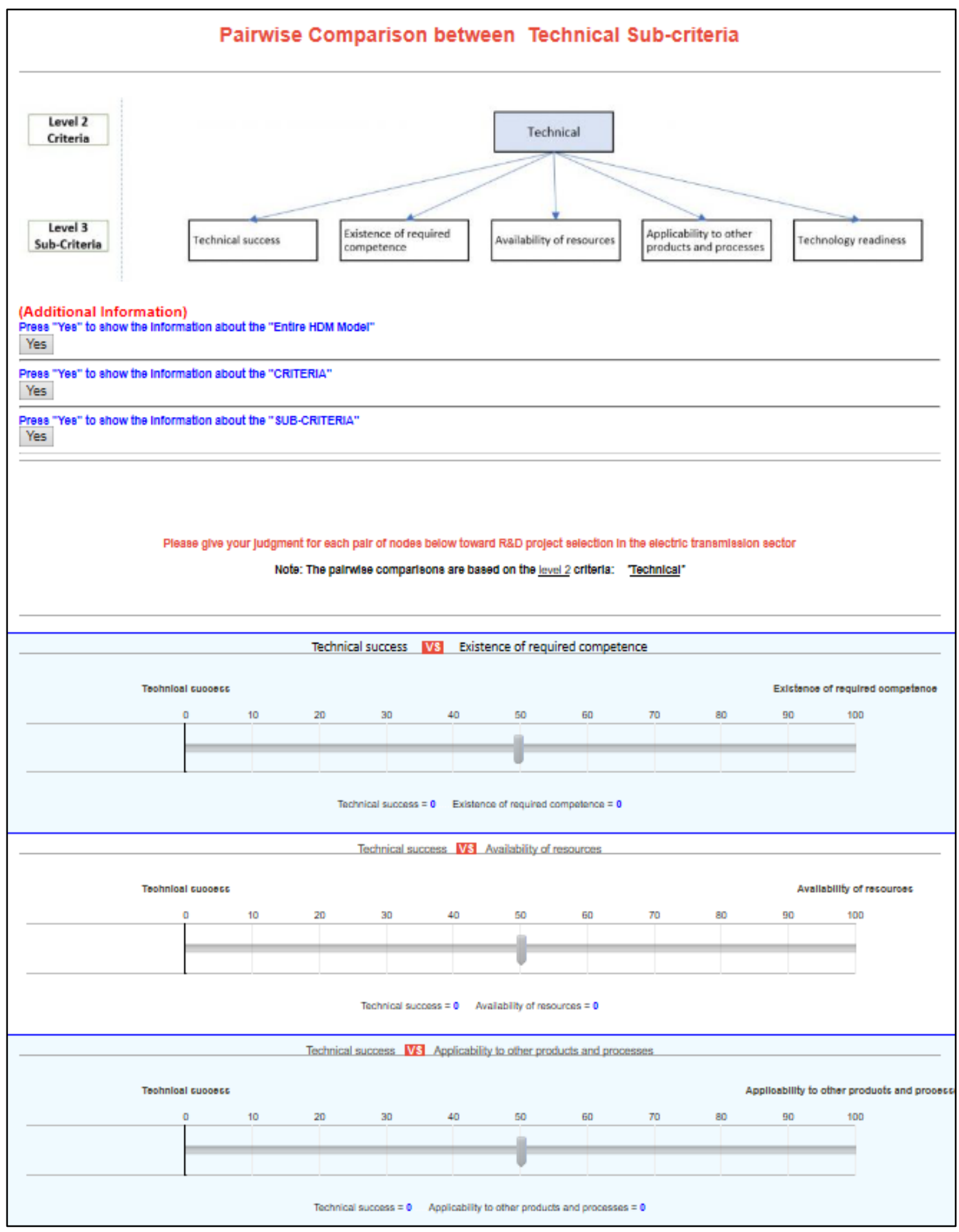




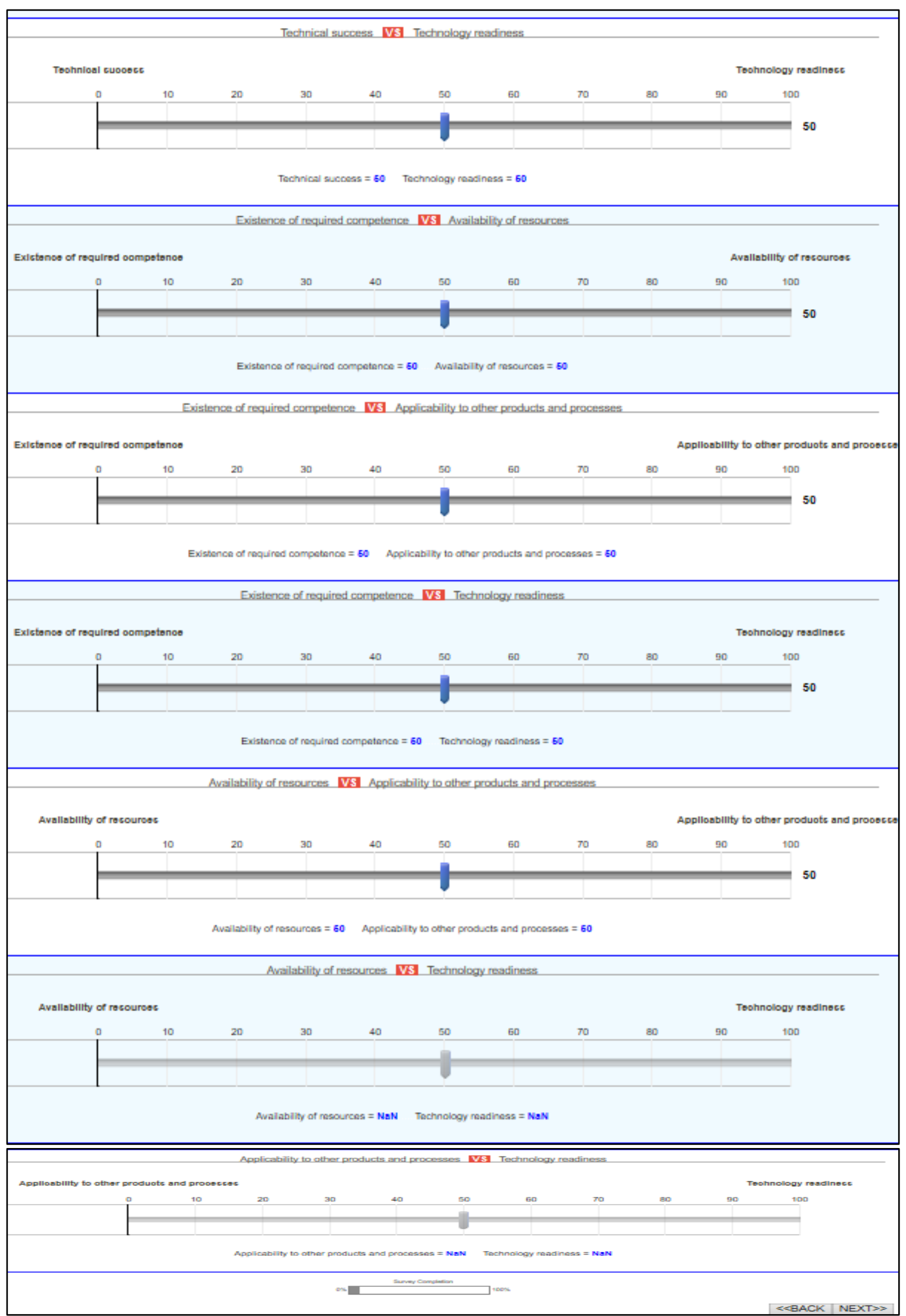




\section{APPENDIX E: Research Instrument RI4: Alternatives Decision Model Quantification}

(This instrument is taken from Qualtrics and kept the format - Example for the Technical Success Sub-criterion)

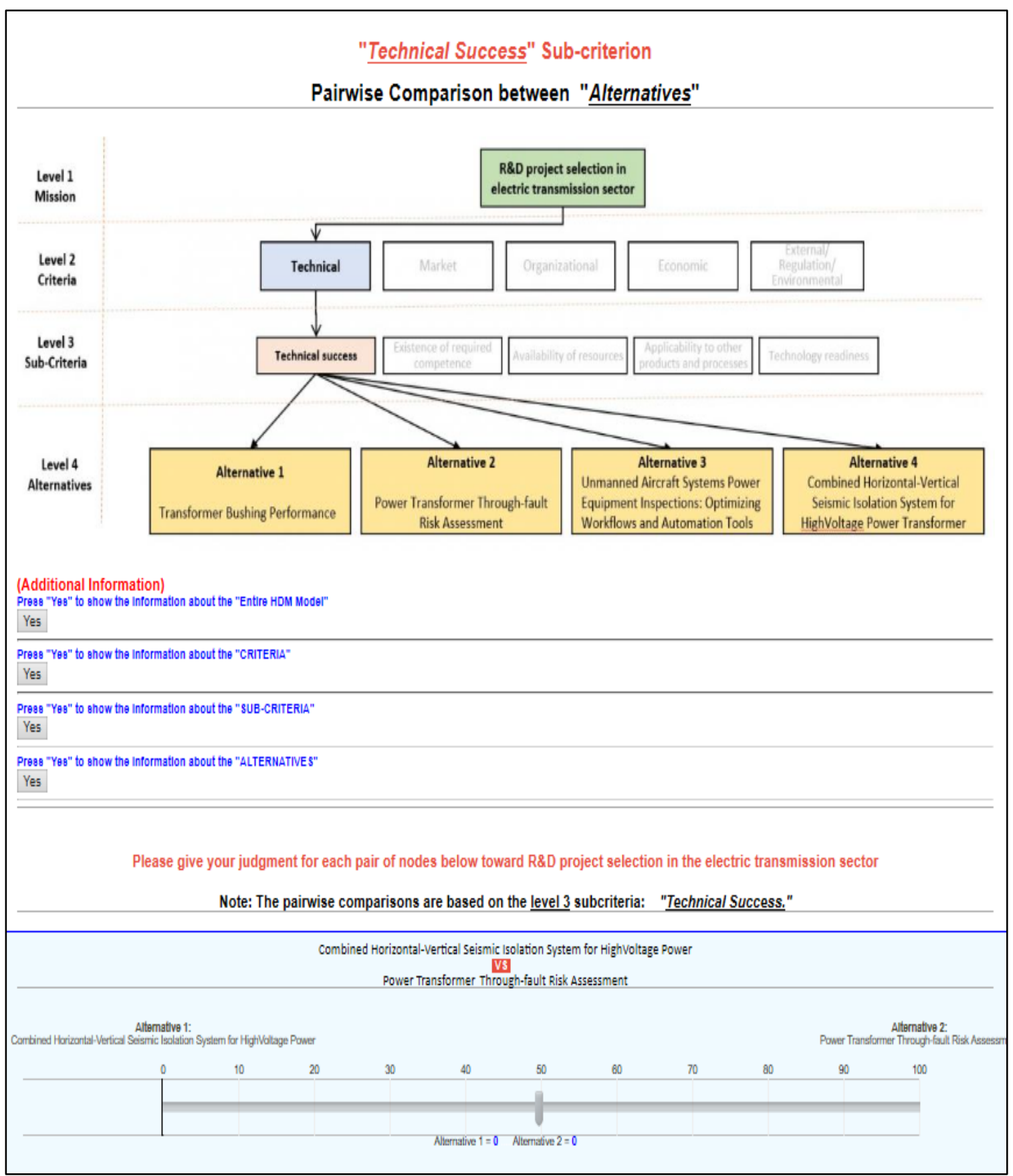




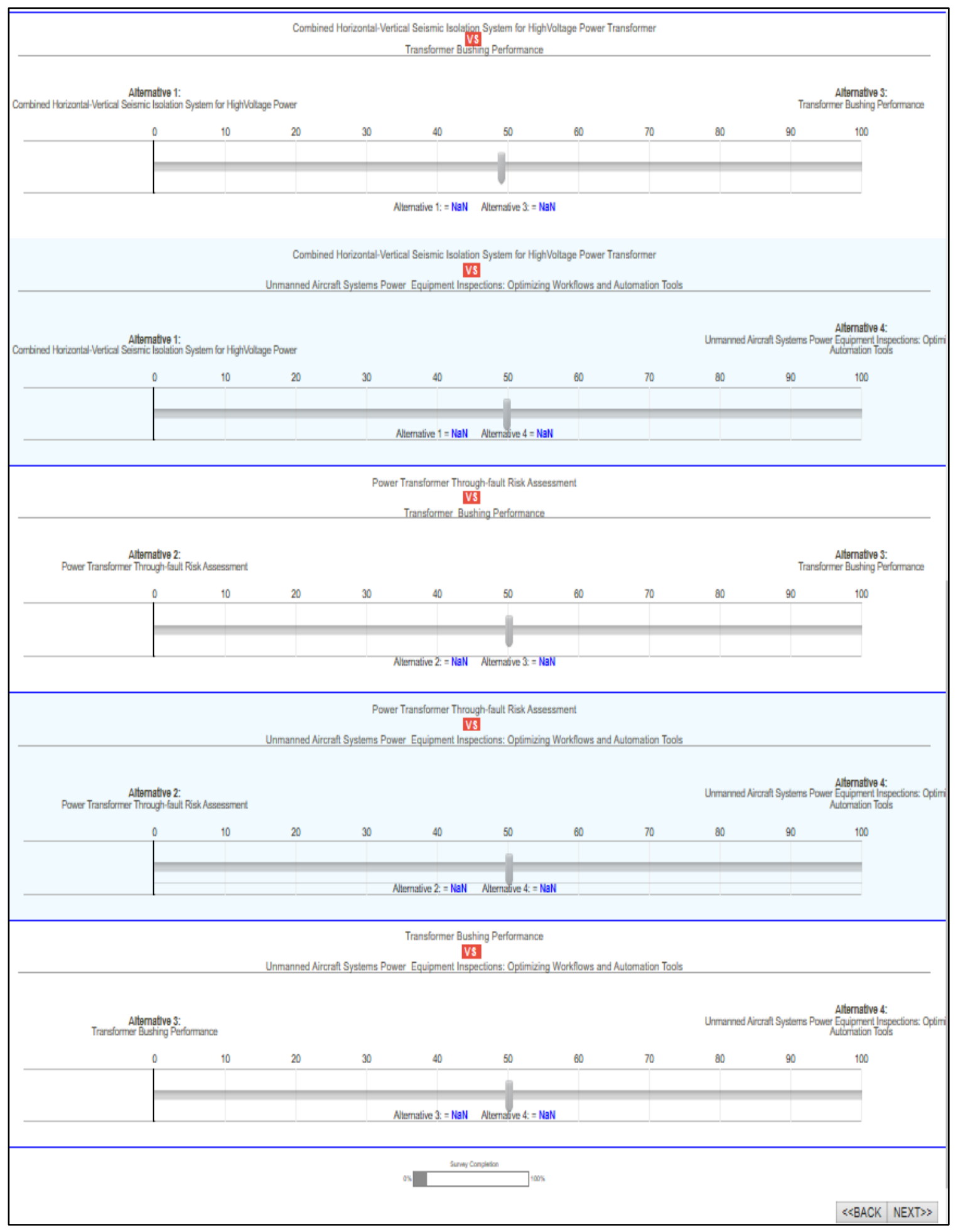




\section{APPENDIX F: Analysis of the Differences Between Criteria Normality Test of Criteria Weights}

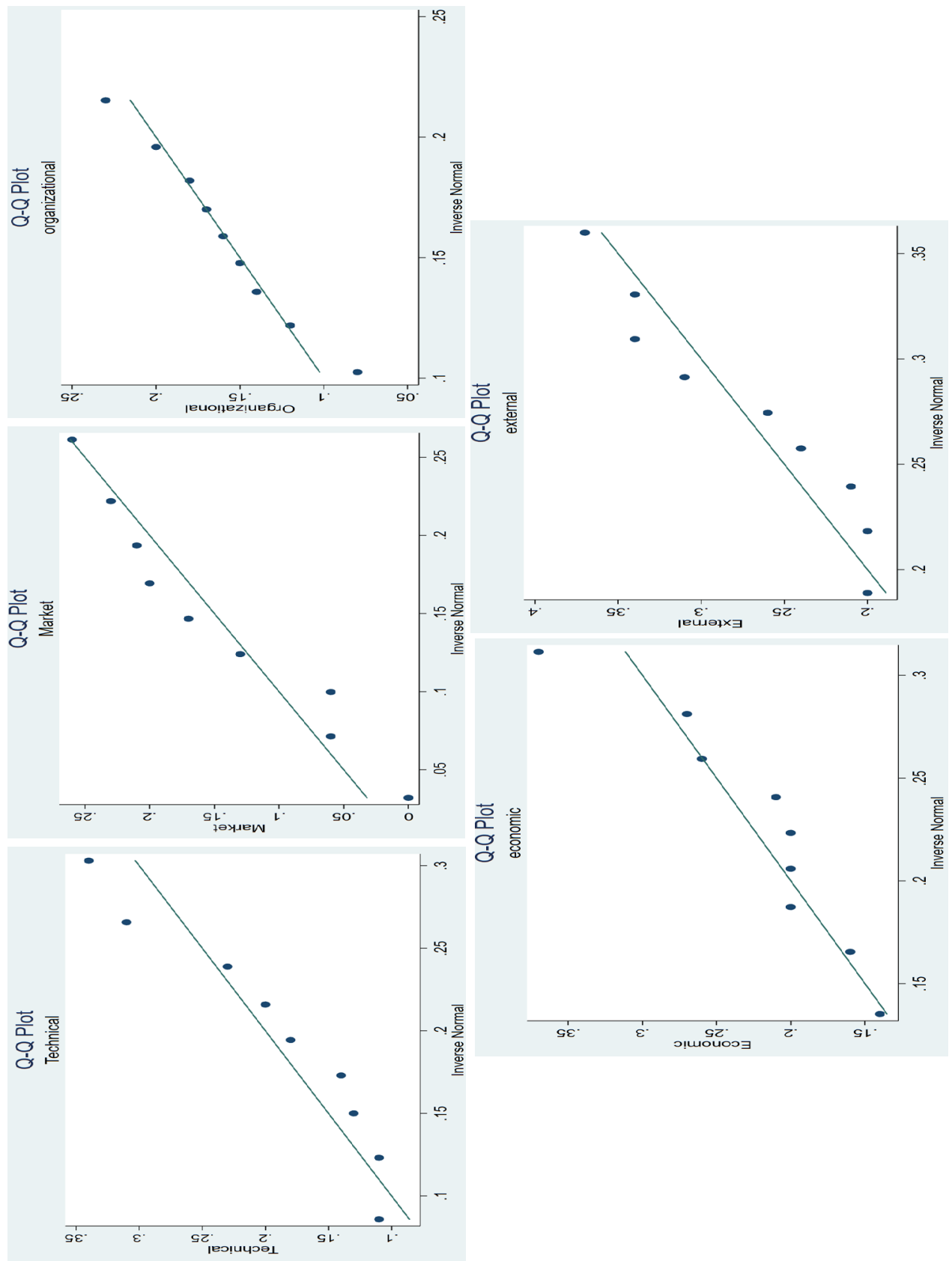

Figure 67: Q-Q Plots - Criteria Weights 


\section{APPENDIX G: Q-Q plots for Normality Tests in Logarithms Values}

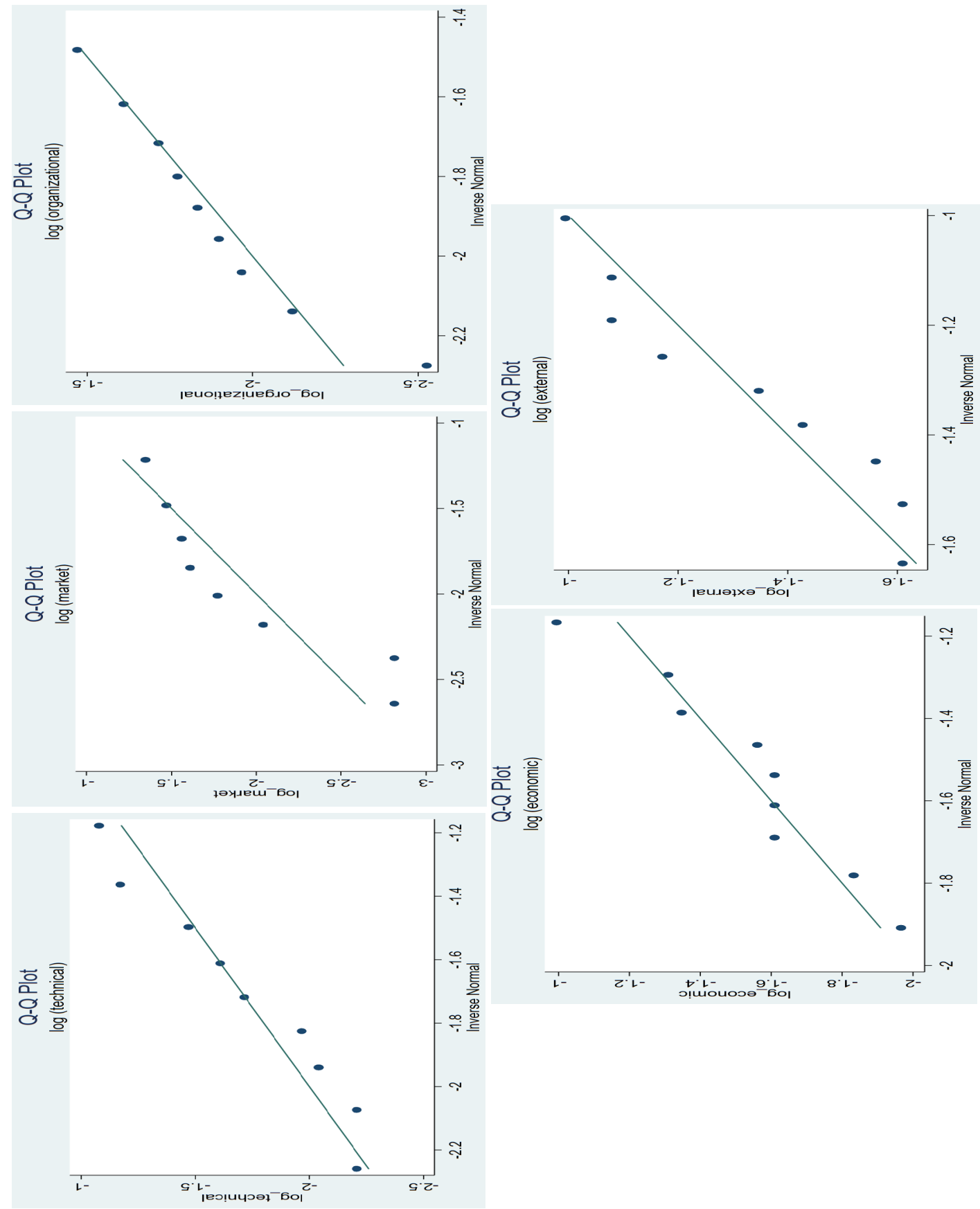

Figure 68: Q-Q Plots - Criteria Weights 


\section{APPENDIX H: Equal Variance Tests}

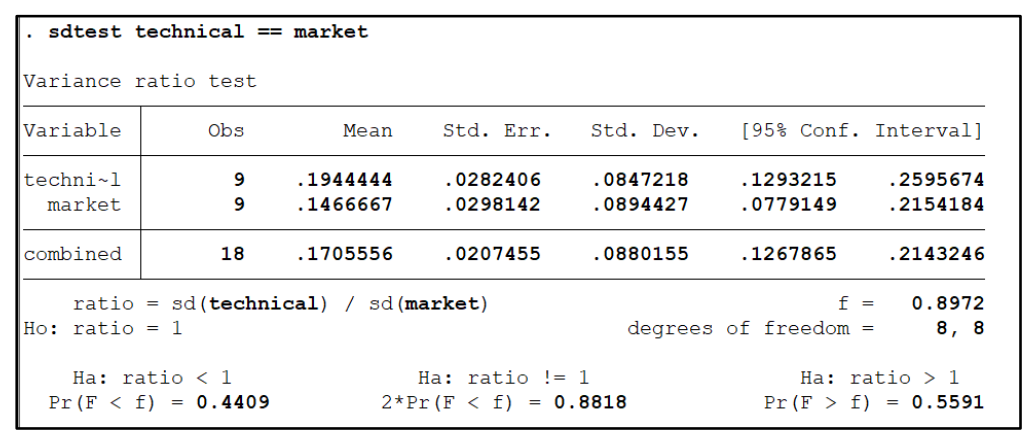

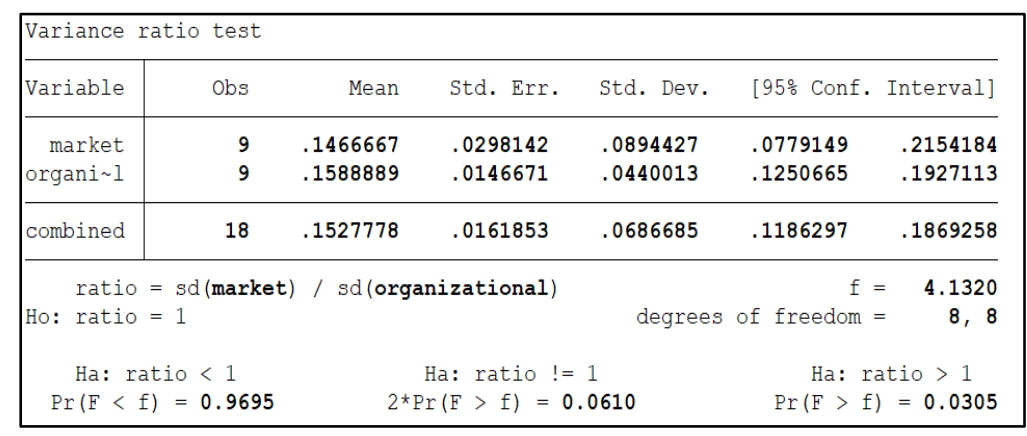

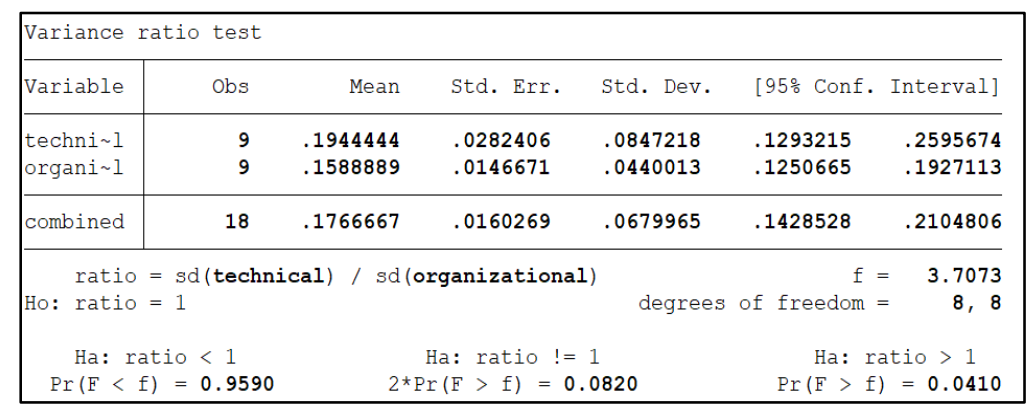




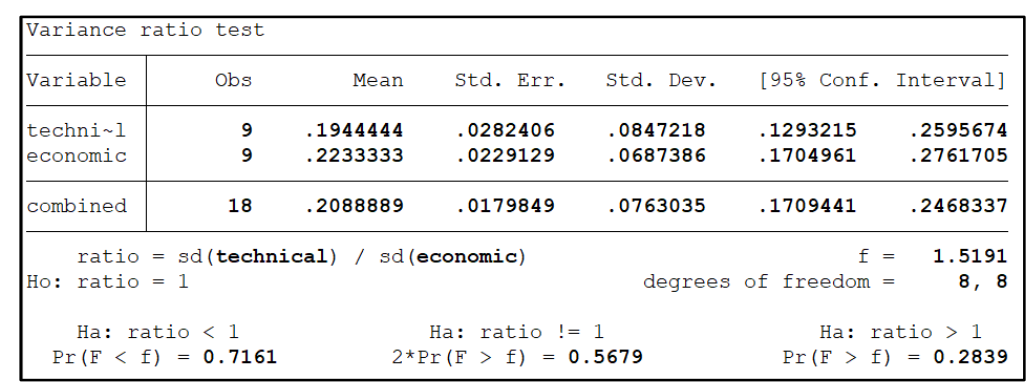

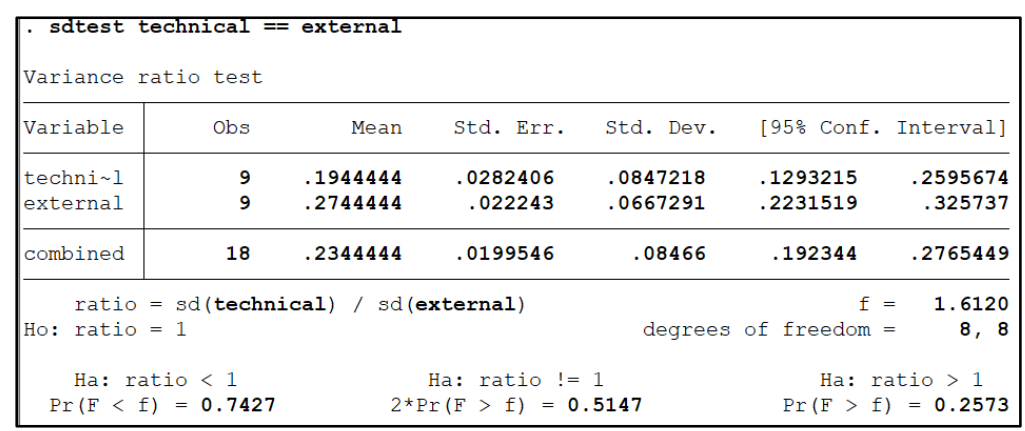




\section{APPENDIX I: Criteria F-test}

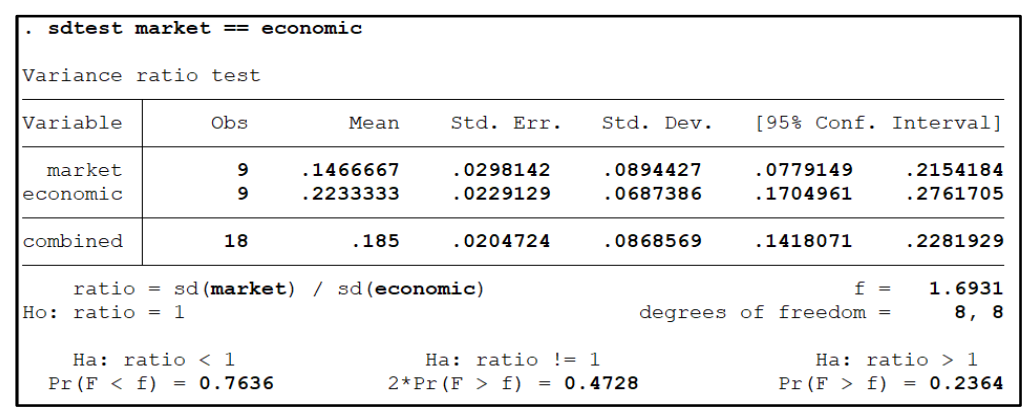

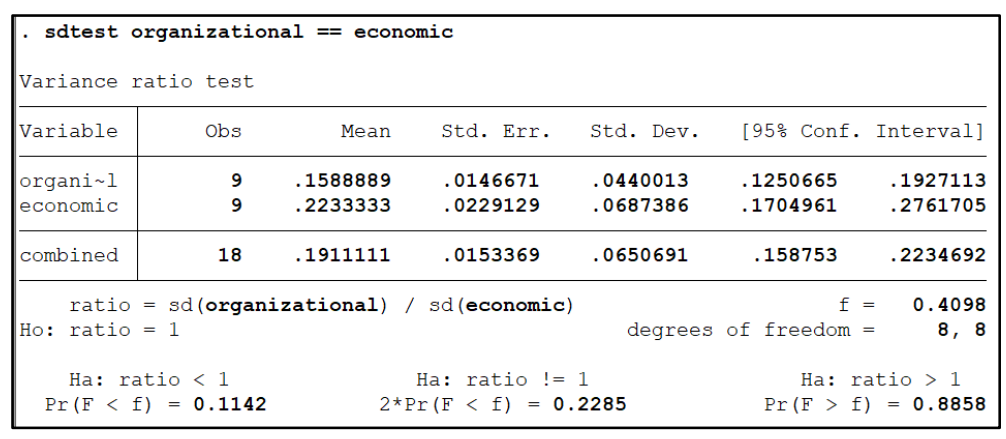

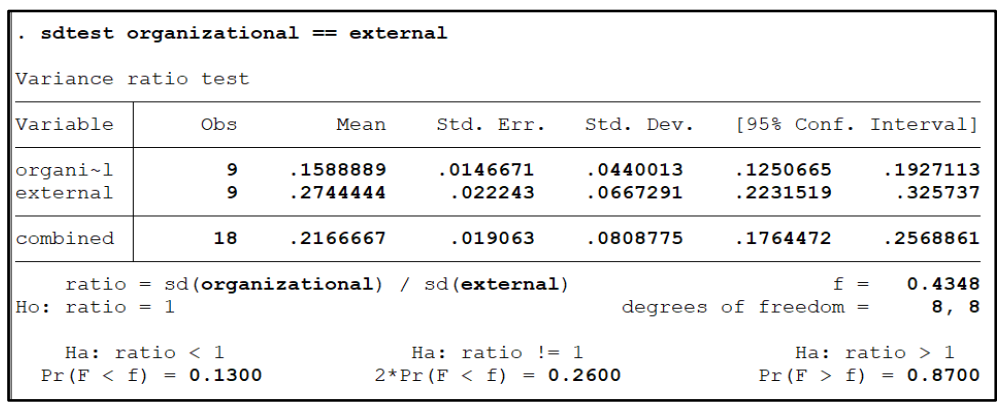

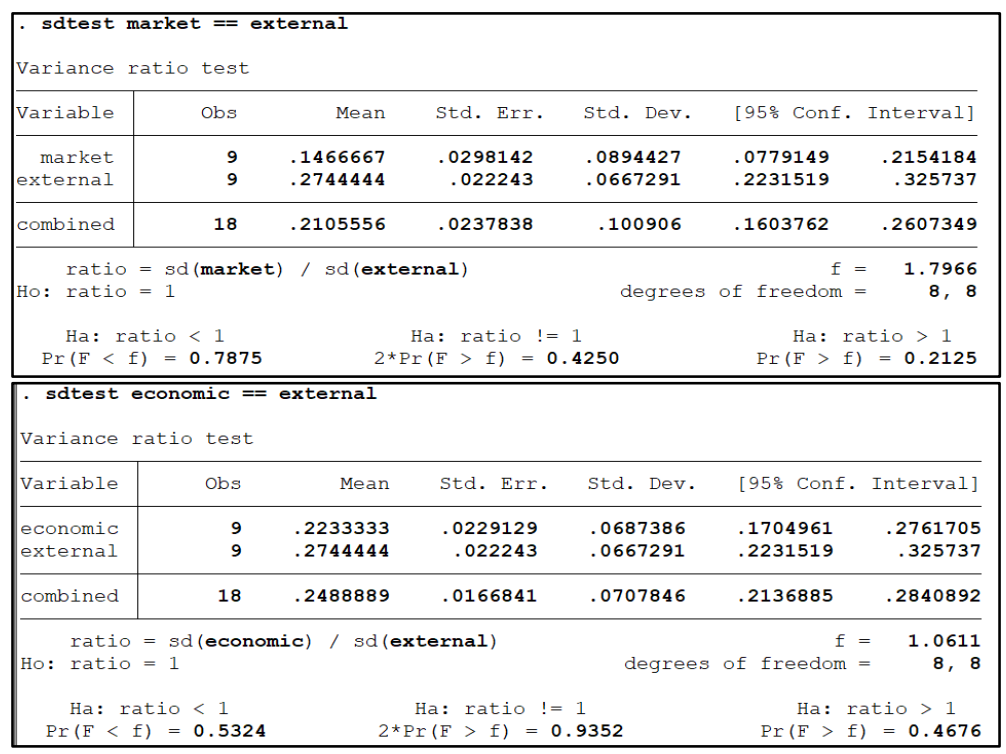

